\title{
Protein Structural Changes During Preparation and Storage of Surimi
}

\author{
Marzieh Moosavi-Nasab \\ Department of Food Science and Agricultural Chemistry \\ Macdonald Campus, McGill University \\ Montréal, Canada
}

December 2003
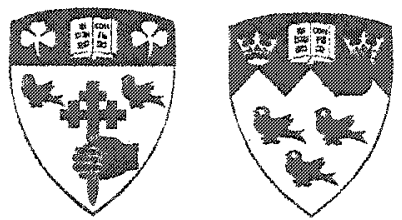

A thesis submitted to the Graduate and Post-Doctoral Studies Office in partial fulfilment of the requirements for the degree of Doctor of Philosophy

(C) M. Moosavi-Nasab, 2003 


$\begin{array}{ll}\begin{array}{l}\text { Library and } \\ \text { Archives Canada }\end{array} & \begin{array}{l}\text { Bibliothèque et } \\ \text { Archives Canada }\end{array} \\ \begin{array}{l}\text { Published Heritage } \\ \text { Branch }\end{array} & \begin{array}{l}\text { Direction du } \\ \text { Patrimoine de l'édition }\end{array} \\ \begin{array}{l}\text { 395 Wellington Street } \\ \text { Ottawa ON K1A 0N4 }\end{array} & \begin{array}{l}\text { 395, rue Wellington } \\ \text { Ottawa ON K1A ON4 } \\ \text { Canada }\end{array} \\ \end{array}$

Your file Votre référence ISBN: 0-612-98330-7

Ourfile Notre référence

ISBN: 0-612-98330-7

NOTICE:

The author has granted a nonexclusive license allowing Library and Archives Canada to reproduce, publish, archive, preserve, conserve, communicate to the public by telecommunication or on the Internet, loan, distribute and sell theses worldwide, for commercial or noncommercial purposes, in microform, paper, electronic and/or any other formats.

The author retains copyright ownership and moral rights in this thesis. Neither the thesis nor substantial extracts from it may be printed or otherwise reproduced without the author's permission.
AVIS:

L'auteur a accordé une licence non exclusive permettant à la Bibliothèque et Archives Canada de reproduire, publier, archiver, sauvegarder, conserver, transmettre au public par télécommunication ou par l'Internet, prêter, distribuer et vendre des thèses partout dans le monde, à des fins commerciales ou autres, sur support microforme, papier, électronique et/ou autres formats.

L'auteur conserve la propriété du droit d'auteur et des droits moraux qui protège cette thèse. $\mathrm{Ni}$ la thèse ni des extraits substantiels de celle-ci ne doivent être imprimés ou autrement reproduits sans son autorisation.
In compliance with the Canadian

Privacy Act some supporting forms may have been removed from this thesis.

While these forms may be included in the document page count, their removal does not represent any loss of content from the thesis.
Conformément à la loi canadienne sur la protection de la vie privée, quelques formulaires secondaires ont été enlevés de cette thèse.

Bien que ces formulaires aient inclus dans la pagination, il n'y aura aucun contenu manquant. 
Dedicated to my mother, Zahra, my husband, Hadi, and my daughter, Faezeh. 


\begin{abstract}
Myofibrillar proteins, the main components that impart functional properties to muscle foods, can undergo denaturation and aggregation during frozen storage. The overall objective of this research was to study the changes in protein structure that are associated with the preparation and frozen storage of surimi. In addition, the relative cryoprotective effects of whey protein concentrate, whey protein isolate, soy protein isolate, flaxseed meal and flaxseed protein were assessed in surimi during storage.

Raw surimi was prepared by repeatedly washing Alaska pollock flesh with chilled water. The product was either slowly frozen or underwent rapid freezing using liquid air; in either case it was then subjected to frozen storage at $-20^{\circ} \mathrm{C}$ for 24 months. Protein structural changes were monitored using sodium dodecyl sulfatepolyacrylamide gel electrophoresis (SDS-PAGE), native-PAGE, Fourier transform infrared/attenuated total reflectance (FTIR/ATR) spectroscopy, and differential scanning calorimetry (DSC).
\end{abstract}

FTIR/ATR spectroscopy showed that during preparation of surimi the $\alpha$-helix content increased with increased number of washing cycles. DSC results revealed a shift in the thermal transition of actin to a higher temperature during surimi preparation. All electrophoresis, FTIR/ATR spectroscopy and DSC results revealed a loss of myofibrillar proteins from surimi after three washing cycles, suggesting that three washing cycles were adequate to prepare surimi.

Native-PAGE showed no major changes in surimi after 24 months storage at $-20^{\circ} \mathrm{C}$. SDS-PAGE showed relatively minor changes in protein subunit structure with 
some loss of the myosin light chains (MLC); myosin heavy chain (MHC), actin and tropomyosin were found to be relatively stable. FTIR/ATR spectroscopy indicated a significant decrease in $\alpha$-helix relative to $\beta$-sheet structure in surimi after 2 years of storage at $-20^{\circ} \mathrm{C}$. The loss of $\alpha$-helical content was more significant in slowly frozen surimi compared to rapid-frozen surimi samples. DSC results revealed a shift in the thermal transition of actin to lower temperatures during frozen storage of surimi.

Changes in the ratio of $\alpha$-helix to $\beta$-sheet structures suggested that flaxseed protein was the most effective cryoprotectant, followed by whey protein isolate and soy protein isolate, for maintaining protein structure stability during frozen storage. Whey protein concentrate and flaxseed meal showed the least cryoprotective ability. After 15 days storage at $4^{\circ} \mathrm{C}$, the SDS-PAGE results showed that flaxseed protein was the only cryoprotectant that prevented the degradation of myosin heavy chain, actin and myosin light chains. 


\section{Résumé}

Les protéines myofibrillaires sont les composantes principales qui possèdent des propriétés fonctionnelles aux produits marins. D'ailleurs, elles peuvent se dénaturer et s'agglomérer lors de la congélation. L'objectif de cette recherche était d'étudier les changements de la structure des protéines associés avec la préparation et la congélation du surimi. De même que les effets sur les agents cryoprotecteurs tels que : concentré de protéine de sérum, protéine lactosérique isolée, protéine de soja isolée, graine de lin et protéine de graine de lin ont été évalués dans le surimi durant la conservation.

Le surimi cru a été préparé en lavant la chair de goberge d'Alaska à maintes reprises avec de l'eau froide. Le produit a été lentement ou rapidement congelé en utilisant de $1^{\prime}$ air liquide. Dans les deux cas, le produit a été congelé à $-20^{\circ} \mathrm{C}$ pendant 24 mois. Les changements de la structure sur la protéine ont été régulés avec l'électrophorèse sur gel de polyacrylamide en présence de SDS (SDS PAGE), PAGE natif, spectroscopie transformée de Fourier par réflectance totale atténuée (FTIR ATR) et par analyse calorimétrique à compensation de puissance (DSC).

La spectroscopie FTIR ATR a démontré que pendant la préparation du surimi, le contenu de $\alpha$-hélix a augmenté avec le nombre de lavage. Les résultats de DSC ont révélé un changement dans la transition thermique de l'actine à une température plus élevée pendant la préparation du surimi. Les résultats spectroscopiques FTR ATR et DSC ont révélé une perte de protéine myofibrillaire de surimi après trois cycles lavage, suggérant que trois cycles lavage aient été suffisants pour préparer le surimi.

Le PAGE natif n'a pas démontré de changement majeur dans le surimi après 24 mois de stockage à une température de $-20^{\circ} \mathrm{C}$. Le SDS PAGE a démontré des 
changements relativement mineurs dans la structure fractionnée de la protéine avec la perte des chaînes de myosine légère (MLC); chaines de myosine lourde (MHC), actine et tropomyosine ont prouvé être relativement stables. La spectroscopie FTIR ATR a indiqué une diminution significative de $\alpha$-hélix relativement à une structure- $\beta$ dans le surimi après 2 années de stockage à une température de $-20^{\circ} \mathrm{C}$. La perte du contenu $\alpha-$ hélicö̈dal était plus significative dans le surimi lentement congelé en comparaison avec les échantillons de surimi rapidement congelés. Les résultats de DSC ont révélé un changement dans la transition thermique de l'actine pour abaisser la température lors de la congélation du surimi.

Les changements dans la proportion de $\alpha$-hélix à une structure- $\beta$ ont suggéré que la protéine de graine de lin était la plus efficace des agents cryoprotecteurs, suivi par la protéine lactosérique isolée et la protéine de soja isolée, dans le maintien de la structure protéique pendant le stockage congelé. Le concentré de protéine de sérum et le repas de graine de lin ont démontré la moins grande capacité cryoprotecteur. Après 15 jours de stockage à $4^{\circ} \mathrm{C}$, les résultats de SDS PAGE ont démontré que la protéine de la graine de lin était la seule protéine à effet cryoprotecteur à empêcher la dégradation de la chaîne de myosine lourde, de l'actine et des chaînes de myosine légère. 


\section{Claim of Originality}

In this study freeze-denaturation and stabilization of protein in surimi were investigated. To the best of the author's knowledge the following are the original contributions made in this work:

- In this study, the optimum number of washing cycles for surimi preparation from Alaska pollock was determined based on solubilization of myofibrillar proteins shown by native-PAGE, SDS-PAGE, FTIR, and DSC.

- The effect of rapid freezing by liquid air on protein stability in surimi was investigated for the first time using electrophoresis and FTIR spectroscopy techniques. A comparative study of rapid and slow freezing was also presented.

- The application of whey protein concentrate, whey protein isolate, soy protein isolate, and flaxseed meal as cryoprotectants in surimi was investigated for the first time.

- This is the first research work to incorporate isolated flaxseed protein in surimi and to establish its potential as an effective cryoprotectant.

- This is the first study to apply FTIR/ATR spectroscopy to investigate the effects of cryoprotectants on surimi protein structure during storage.

- FTIR and electrophoresis analyses were correlated for the first time in surimi investigations. 


\section{Acknowledgements}

\section{In the Name of God the Compassionate and Merciful}

Nothing would have been achieved in my life without the will of God, to whom I am indebted my entire being. I cannot thank God enough for what He gave me, least of which maybe the courage, patience and perseverance to perform my studies.

Next I would like to express my sincere thanks to my supervisor Dr. I. Alli for his guidance and support during the course of this work. His critical review of this manuscript and his valuable suggestions are greatly appreciated. I would also like to thank Dr. Alli's family for their kindness and hospitality.

My gratitude also goes to Dr. A. Ismail, Dr. S. Kermasha, and Dr. M. Ngadi for granting me the use of their laboratory facilities as well as useful discussions during my work. Special thanks are due to Dr. J. Sedman for hours of valuable discussions she devoted to my work, and to Dr. L. Kassama for his training and share of his expertise in DSC. I would also like to thank Dr. P. Ager for his assistance in translating the thesis abstract to French.

Thanks are also due to many colleagues and friends at the campus for their friendship, support, and encouragement during my graduate studies. I would like to specifically thank Dr. Anahita Keyhani, Dr. Wijdan Madani, Farial, Romaina, Sahel, Neda, and Zahra for their friendship and support, and also thank my colleagues Dr. Husam Alomirah, Dr. Ahmeda Alzagtat, Razan, Haroon and Muhammed for their help during my studies at McGill. The support of all the professors and departmental staff, in particular Mr. Ebi Noroozi, Mrs. L. Stieble and Mrs. B. Lapline, is also highly appreciated. 
No word can describe my sincere gratitude to my family, especially my mother and my siblings-Mohammad Bagher, Ghamarossadat, Farzaneh, Yousef, and Sadegh-for their moral support and encouragement during my entire life and particularly throughout my graduate studies in Canada. I would like to specifically thank my brothers-in-law, Mr. Taheri and Dr. Izedi, for all their help and support. I would also like to dedicate this work to my family, and especially to the memory of my father, Seyed Khalil Moosavi-Nasab.

Last, but certainly not least, my especial thanks to my dear husband, Hadi, and my daughter, Faezeh, for their love, patience, encouragement, and support during my graduate studies. I am especially thankful to Faezeh for allowing me to spend so much time on my work instead of with her even during the weekends and holidays. I hope the final outcome of this endeavor will overweight her sacrifices. 


\section{Table of Contents}

Abstract

Resume

Claim of Origimality v

Acknowledgements vi

Table of Contents viii

List of Figures xii

List of Tables xix

Abbreviations

\section{Chapter 1 INTODUCTION}

1.1. General 1

1.2. Rationale and Objectives of Study 3

\section{Chapter 2 LITERATURE REVIEW}

2.1. Nitrogenous Components of Fish Muscle 5

2.1.1. Total Contents and Composition 5

2.1.2. The Sarcoplasmic Proteins 8

2.1.3. The Myofibrillar Proteins 8

2.1.4. The Proteins of Stroma 12

2.2. The Functional Properties of Fish Protein 12

2.2.1. Formation of Gel Structure 13

2.2.2. The Hydration of Proteins 14

2.2.3. Emulsifying Properties 15

2.3. Postharvest Biochemical Changes in Fish Muscle 15

2.4. Surimi Composition and Preparation 17

2.5. Freezing, Frozen Storage, and Thawing of Surimi 19

2.6. Freeze Denaturation of Myofibrillar Proteins 21

2.7. Stabilization of Protein in Surimi 25 
2.7.1. Cryoprotectants 25

2.7.2. Other Additives to Improve the Functional Properties 34

2.7.2.1. Macromolecular Extenders 34

2.7.2.2. Fats and Oils 35

2.7.2.3. Protein Additives 36

2.8. Techniques to Identify Structural Changes in Protein 38

2.8.1. Electrophoresis 38

2.8.2. Infrared Spectroscopy 39

2.8.3. Differential Scanning Calorimetry (DSC) 42

Chapter 3 CHANGES IN PROTEIN STRUCTURE DURING PREPARATION AND FROZEN STORAGE OF ALASKA POLLOCK SURIMI

3.0. Introduction 44

3.1. Materials and Methods 45

3.1.1. Preliminary Experiments 45

3.1.1.1. Preparation of Surimi 45

3.1.1.2. Separation of Fish Protein Fractions 46

3.1.2. Surimi Preparation from Alaska pollock 47

3.1.3. Protein Determination 47

3.1.4. Electrophoretic Analyses 49

3.1.4.1. SDS-PAGE 49

3.1.4.1.1. Sample Preparation 49

3.1.4.1.2. Gel Concentration and Preparation 50

3.1.4.1.3. Electrophoresis Running Conditions 50

3.1.4.1.4. Protein Fixing, Staining, and Destaining 51

3.1.4.2. Native-PAGE 51

3.1.4.2.1. Sample Preparation 51

3.1.4.2.2. Gel Concentration and Preparation 52

3.1.4.2.3. Electrophoresis Running Conditions 52

3.1.4.2.4. Protein Fixing, Staining, and Destaining 52

3.1.5. FTIR/ATR Spectroscopy 52 
3.1.6. Differential Scanning Calorimetry (DSC) 53

3.2. Results and Discussion 54

3.2.1. Preliminary Experiments 54

3.2.2. Surimi Preparation from Alaska pollock 58

3.2.3. Properties of Wash Waters 59

3.2.3.1. Electrophoretic Analysis 59

3.2.3.2. FTIR/ATR Analysis 61

3.2.3.3. DSC Analysis 64

3.2.4. Protein Changes in Minced Fish During Preparation of Surimi 66

3.2.4.1. Native-PAGE 66

3.2.4.2. SDS-PAGE 70

3.2.4.3. FTIR/ATR Analysis 70

3.2.4.4. DSC Analysis 76

3.2.5. Changes During Frozen Storage of Surimi 79

3.2.5.1. Native-PAGE 79

3.2.5.2. SDS-PAGE 81

3.2.5.3. FTIR/ATR Analysis 84

$\begin{array}{lll}\text { 3.2.5.4. DSC Analysis } & 87\end{array}$

\section{Chapter 4 EFFECT OF CRYOPROTECTANTS ON THE STABILITY OF PROTEINS IN SURIMI DURING STORAGE}

4.0. Introduction 90

4.1. Materials and Methods 91

4.1.1. Preparation of Raw Surimi 91

4.1.2. Treatment of Surimi with Cryoprotectants 91

4.1.3. Storage 91

4.1.4. Commercial Surimi Products 93

4.1.5. Extraction and Precipitation of Defatted Flaxseed

4.1.6. Protein Measurement 94 
4.1.7. $\mathrm{pH}$ Measurement 94

4.1.8. Electrophoretic Analyses 94

4.1.9. FTIR/ATR Spectroscopy 96

4.2. Results and Discussion 97

4.2.1. Surimi Preparation . 97

4.2.2. Properties of Wash Waters 97

4.2.3. Electrophoresis Analyses on Cryoprotectantns 100

4.2.4. Changes During Storage of Surimi 103

$\begin{array}{lll}\text { 4.2.4.1. } & \mathrm{pH} & 104\end{array}$

4.2.4.2. Electrophoretic Analyses 106

$\begin{array}{lll}\text { 4.2.4.2.1. Native-PAGE } & 106\end{array}$

4.2.4.2.2. SDS-PAGE 111

$\begin{array}{lll}\text { 4.2.4.3. } & \text { FTIR/ATR Spectroscopy } & 120\end{array}$

\section{Chapter 5 GENERAL CONCLUSIONS}

5.1. Summary and Conclusion 143

5.2. Future Work 145

$\begin{array}{ll}\text { References } & 146\end{array}$ 


\section{List of Figures}

Figure 2.1 Schematic diagram of fish muscle protein composition. 1(Sikorski et al., 1990b); ${ }^{2}$ (Hall and Ahmad, 1997); 3 (Mackie, 1993)

Figure 2.2 The structural organization of fish fillet (from Goodband, 2002)

Figure 2.3 Schematic diagram of (a) the myosin molecule and (b) its subfragments (from Mackie, 1993 and Visessanguan et al., 2000)

Figure 2.4 Flow diagram of surimi manufacturing process with estimated yield. $\mathrm{NaCl}^{*}$ : $\mathrm{NaCl}$ can be added for better removal of water (from Park et al., 1997)

Figure 2.5 Postulated mechanism for the conversion of myofibrillar proteins into inextractable protein (from King, 1966)

Figure 2.6 Diagramatic representation of a possible effect of freezing out of water on the water-mediated hydrophobic-hydrophilic linkage in a protein molecule (from Sikorski et al., 1976)

Figure 2.7 A schematic model of denaturation (aggregation) of $\alpha$-helical proteins during frozen storage and its prevention by cryprotectants. $-\oplus$, cationic side chain; $-\ominus$, anionic side chain; - - , nonpolar side chain; - water molecule; $\ominus-\ominus$, dianionic cryoprotectant molecule (from Matsumoto, 1980) .....

Figure 2.8 A schematic model of denaturation of non-helical (globular) proteins during frozen storage and its prevention by cryoprotectants. . $-\oplus$, cationic side chain; $-\ominus$, anionic side chain; -O, nonpolar side chain; water molecule; $\Theta-\Theta$, dianionic cryoprotectant molecule (from Matsumoto, 1980) ....

Tigure 3.1 Procedure used for preparing surimi from Alaska pollock .......

Wigure 3.2 SDS-PAGE patterns of minced fish, surimi, wash water, and protein fractions of fish; 1 third wash water, 2 sarcoplasmic proteins, 3 and 7 minced fish, 4 and 11 myofibrillar proteins, 5 and 8 market surimi, 6 surimi $(3: 1 \mathrm{~W} / \mathrm{M}), 9$ surimi $(5: 1 \mathrm{~W} / \mathrm{M}), 10$ surimi with added salt $(5: 1 \mathrm{~W} / \mathrm{M}), 12$ collagen, St. broad range standard 
Figure 3.3 SDS-PAGE patterns of wash waters; $1-5$ first to firth washing cycle, lyophilized samples; 6-10 first to fifth washing cycles, liquid samples

Figure 3.4 Baseline corrected FTIR/ATR spectra of wash waters; a to e, first to fifth wash water

Figure 3.5 Deconvolved FTIR/ATR spectra of wash waters; a to e, first to fifth wash water

Figure 3.6 DSC thermograms of wash waters and standards (a) $1^{\text {st }}$ wash water, (b) $5^{\text {th }}$ wash water, (c) actin, (d) indium

Figure 3.7 Native-PAGE patterns of minced fish and surimi, 1 minced fish; 2-6 first to fifth surimi ( $t=2 \mathrm{yr})$; St. HMW standard. A: myosin heavy chain; $\mathrm{B}$ : $\alpha$-actinin; $\mathrm{C}$ : tropomyosin; $\mathrm{D}$ : actin; $\mathrm{E}$ and $\mathrm{F}$ : myosin light chains

Figure 3.8 Native-PAGE patterns of minced fish and surimi, St. actin, 1 minced fish; 2-6 first to fifth surimi $(t=0)$

Figure 3.9 SDS-PAGE patterns of minced fish and surimi, 1 minced fish; 26 first to fifth surimi ( $t=2 \mathrm{yr}$ ); St. broad range standard. A: myosin aggregate; $B$ : myosin heavy chain; $C$ : m-protein; $D: c-$ protein; $\mathrm{E}$ : $\alpha$-actinin; $\mathrm{F}$ : actin; $\mathrm{G}$ : creatine kinase; $\mathrm{H}: \beta$ tropomyosin; I: $\alpha$-tropomyosin; $\mathrm{J}, \mathrm{K}, \mathrm{L}$, and $\mathrm{M}$ : myosin light chains; $N$ : myoglobin

Figure 3.10 Stacked plot of deconvolved FTIR/ATR spectra of minced fish and surimi with the addition of $\mathrm{D}_{2} \mathrm{O}$ (top); percentage of $\alpha$-helix, $\beta$-sheet structures and their ratio (bottom)

Figure 3.11 DSC thermograms of (a) frozen minced fish, (b) freeze-dried minced fish, (c) myosin, (d) freeze-dried surimi

Tigure 3.12 DSC thermograms of (a) minced fish at time 0 , (b) surimi $5^{\text {th }}$ at time 0 ; heating rate at $5^{\circ} \mathrm{C} / \mathrm{min}$

Figure 3.13 Native-PAGE patterns of minced fish and surimi at times 0,1 , and $2 \mathrm{yr}$, respectively; 1-3 minced fish; 4-6 surimi 5 th slow frozen; $7-9$ surimi 5 th rapid frozen; St. HMW standard

Tigure 3.14 SDS-PAGE patterns of minced fish and surimi at times 0, 1, and $2 \mathrm{yr}$, respectively; 1-3 minced fish; 4-6 surimi 5th slow frozen; 79 surimi 5 th rapid frozen; St. broad range standard 
Figure 3.15 Stacked plot of deconvolved FTR/ATR spectra of surimi, at time 0 and after 2 years of storage, with the addition of $\mathrm{D}_{2} \mathrm{O}$ (top); percentage of $\alpha$-helix, $\beta$-sheet structures and their ratio (bottom)

Figure 3.16 DSC thermograms of (a) minced fish at time 0 , (b) minced fish after 2 years of storage, (c) surimi $5^{\text {th }}$ at time 0 , (d) surimi $5^{\text {th }}$ after 2 years of storage; heating rate at $5^{\circ} \mathrm{C} / \mathrm{min}$

Figure 3.17 DSC thermograms of (a) rapid-frozen surimi $5^{\text {th }}$ at $t=0$, (b) rapid frozen surimi $5^{\text {th }}$ at $\mathrm{t}=2 \mathrm{yr}$

Figure 4.1 Procedure used to prepare surimi with different additives .......

Figure 4.2 Procedure used to prepare protein isolates from defatted flaxseed meal

Figure 4.3 Electrophoretic patterns of wash waters: (a) native-PAGE, St. high molecular weight (HMW) standard; 1-3 lyophilized samples of $1^{\text {st }}$ to $3^{\text {rd }}$ wash waters; 4-6 liquid samples of $1^{\text {st }}$ to $3^{\text {rd }}$ wash waters; (b) SDS-PAGE, St. broad range molecular weight standard; 1 minced fish; $2-4$ liquid samples of $1^{\text {st }}$ to $3^{\text {rd }}$ wash waters; 5-7 lyophilized samples of $1^{\text {st }}$ to $3^{\text {rd }}$ wash waters

Figure 4.4 Stacked plot of deconvolved FTIR/ATR spectra of lyophilized samples of wash waters (top); percentage of $\alpha$-helix, $\beta$-sheet structures and their ratio (bottom)

Figure 4.5 Electrophoretic patterns of individual cryoprotectants: (a) nativePAGE, St. high molecular weight (HMW) standard; 1 whey protein concentrate (WPC); 2 whey protein isolate (WPI); 3 soy protein isolate (SPI); 4 flaxseed protein (FP); 5 flaxseed meal (FM); (b) SDS-PAGE, St. broad range molecular weight standard; 1 WPC; 2 WPI; 3 SPI; 4 FP; 5 FM

Tigure 4.6 pH of different products at $t=0$ and after $15 \mathrm{~d}$ storage at $4 \mathrm{C} ; \mathrm{MF}$ minced fish, S1 surimi $1^{\text {st }}, \mathrm{S} 2$ surimi $2^{\text {nd }}, \mathrm{S} 3$ surimi $3^{\text {td }}, \mathrm{WPC}$ surimi with whey protein concentrate, WPI surimi with whey protein isolate, SPI surimi with soy protein isolate, FM surimi with flaxseed meal, FP $1 \%$ surimi with $1 \%$ flaxseed protein, FP $3 \%$ surimi with $3 \%$ flaxseed protein, MS market surimi, LO lobster-flavored surimi, SC scallop-flavored surimi, CR crabflavored surimi 
Figure 4.7 Native-PAGE patterns of minced fish and surimi at time 0 : (a) St. HMW standard; 1 minced fish; 2 surimi $1^{\text {st }} ; 3$ surimi $2^{\text {nd }} ; 4$ surimi $3^{\text {rd }} ; 5$ market surimi; $6 \mathrm{LO} ; 7 \mathrm{SC} ; 8 \mathrm{CR}$; (b) St. HMW standard; 1 minced fish; 2 surimi $3^{\text {rd }} ; 3$ surimi with WPC; 4 surimi with WPI; 5 surimi with SPI; 6 surimi with FM; 7 surimi with $1 \% \mathrm{FP} ; 8$ surimi with $3 \% \mathrm{FP}$ (for abbreviations refer to Figure 4.6)

Figure 4.8 Native-PAGE patterns of minced fish and surimi after 6 mo storage at $-20^{\circ} \mathrm{C}$ : (a) St. HMW standard; 1 minced fish; 2 surimi $1^{\text {st }} ; 3$ surimi $2^{\text {nd }} ; 4$ surimi $3^{\text {rd }} ; 5$ market surimi; $6 \mathrm{LO} ; 7 \mathrm{SC} ; 8 \mathrm{CR}$; (b) St. HMW standard; 1 minced fish; 2 surimi $3^{\text {rd }} ; 3$ surimi with WPC; 4 surimi with WPI; 5 surimi with SPI; 6 surimi with FM; 7 surimi with $1 \% \mathrm{FP} ; 8$ surimi with $3 \% \mathrm{FP}$ (for abbreviations refer to Figure 4.6)

Figure 4.9 Native-PAGE patterns of minced fish and surimi after $5 \mathrm{~d}$ storage at $4^{\circ} \mathrm{C}$ : (a) St. HMW standard; 1 minced fish; 2 surimi $1^{\text {st }} ; 3$ surimi $2^{\text {nd }} ; 4$ surimi $3^{\text {rd }} ; 5$ market surimi; $6 \mathrm{LO} ; 7 \mathrm{SC} ; 8 \mathrm{CR}$; (b) St. HMW standard; 1 minced fish; 2 surimi $3^{\text {rd }} ; 3$ surimi with WPC; 4 surimi with WPI; 5 surimi with SPI; 6 surimi with FM; 7 surimi with $1 \% \mathrm{FP} ; 8$ surimi with $3 \% \mathrm{FP}$ (for abbreviations refer to Figure 4.6)

Figure 4.10 Native-PAGE patterns of minced fish and surimi after $10 \mathrm{~d}$ storage at $4^{\circ} \mathrm{C}$ : (a) St. HMW standard; 1 minced fish; 2 surimi $1^{\text {st }} ; 3$ surimi $2^{\text {nd }} ; 4$ surimi $3^{\text {rd }} ; 5$ market surimi; $6 \mathrm{LO} ; 7 \mathrm{SC} ; 8 \mathrm{CR}$; (b) St. HMW standard; 1 minced fish; 2 surimi $3^{\text {rd }} ; 3$ surimi with WPC; 4 surimi with WPI; 5 surimi with SPI; 6 surimi with FM; 7 surimi with $1 \% \mathrm{FP} ; 8$ surimi with $3 \% \mathrm{FP}$ (for abbreviations refer to Figure 4.6 )

Tigure 4.1 Native-PAGE patterns of minced fish and surimi after $15 \mathrm{~d}$ storage at $4^{\circ} \mathrm{C}$ : (a) St. HMW standard; 1 minced fish; 2 surimi $1^{\text {st }} ; 3$ surimi $2^{\text {nd }} ; 4$ surimi $3^{\text {rd }} ; 5$ market surimi; 6 LO 7 SC; $8 \mathrm{CR}$; (b) St. HMW standard; 1 minced fish; 2 surimi $3^{\text {rd }} ; 3$ surimi with WPC; 4 surimi with WPI; 5 surimi with SPI; 6 surimi with FM; 7 surimi with $1 \% \mathrm{FP} ; 8$ surimi with $3 \% \mathrm{FP}$ (for abbreviations refer to Figure 4.6) 
Tigure 4.12 SDS-PAGE patterns of minced fish and surimi at time 0: (a) St. broad range molecular weight standard; 1 minced fish; 2 surimi $1^{\text {st }} ; 3$ surimi $2^{\text {nd }} ; 4$ surimi $3^{\text {rd }} ; 5$ market surimi; $6 \mathrm{LO} ; 7 \mathrm{SC} ; 8 \mathrm{CR}$; (b) St. broad range molecular weight standard; 1 minced fish; 2 surimi $3^{\text {rd }} ; 3$ surimi with WPC; 4 surimi with WPI; 5 surimi with SPI 6 surimi with $\mathrm{FM} ; 7$ surimi with $1 \% \mathrm{FP} ; 8$ surimi with $3 \%$ FP (for abbreviations refer to Figure 4.6)

Figure 4.13 SDS-PAGE pattems of minced fish and surimi after 6 mo storage at $-20^{\circ} \mathrm{C}$ : (a) St. broad range molecular weight standard; 1 minced fish; 2 surimi $1^{\text {st }} ; 3$ surimi $2^{\text {nd }} ; 4$ surimi $3^{\text {rd }} ; 5$ market surimi; $6 \mathrm{LO} ; 7 \mathrm{SC}$; $8 \mathrm{CR}$; (b) St. broad range molecular weight standard; 1 minced fish; 2 surimi $3^{\text {rd }} ; 3$ surimi with WPC; 4 surimi with WPI; 5 surimi with SPI; 6 surimi with FM; 7 surimi with $1 \% \mathrm{FP} ; 8$ surimi with $3 \% \mathrm{FP}$ (for abbreviations refer to Figure 4.6)

Figure 4.14 SDS-PAGE patterns of minced fish and surimi after $5 \mathrm{~d}$ storage at $4^{\circ} \mathrm{C}$ : (a) St. broad range molecular weight standard; 1 minced fish; 2 surimi $1^{\text {st }} ; 3$ surimi $2^{\text {nd. }} ; 4$ surimi $3^{\text {rd }} ; 5$ market surimi; 6 LO; 7 SC; 8 CR; (b) St. broad range molecular weight standard; 1 minced fish; 2 surimi $3^{\text {rd }} ; 3$ surimi with WPC; 4 surimi with WPI; 5 surimi with SPI; 6 surimi with FM; 7 surimi with $1 \% \mathrm{FP}$; 8 surimi with $3 \% \mathrm{FP}$ (for abbreviations refer to Figure 4.6 ) .....

Figure 4.15 SDS-PAGE patterns of minced fish and surimi after $10 \mathrm{~d}$ storage at $4^{\circ} \mathrm{C}$ : (a) St. broad range molecular weight standard; 1 minced fish; 2 surimi $1^{\text {st }} ; 3$ surimi $2^{\text {nd }} ; 4$ surimi $3^{\text {rd }} ; 5$ market surimi; 6 LO; $7 \mathrm{SC} ; 8 \mathrm{CR}$; (b) St. broad range molecular weight standard; 1 minced fish; 2 surimi $3^{\text {rd }} ; 3$ surimi with WPC; 4 surimi with WPI; 5 surimi with SPI; 6 surimi with FM; 7 surimi with $1 \%$ FP; 8 surimi with $3 \% \mathrm{FP}$ (for abbreviations refer to Figure 4.6 ) $\ldots .$.

Figure 4.16 SDS-PAGE patterns of minced fish and surimi after $15 \mathrm{~d}$ storage at $4^{\circ} \mathrm{C}$ : (a) St. broad range molecular weight standard; 1 minced fish; 2 surimi $1^{\text {st }} ; 3$ surimi $2^{\text {nd }} ; 4$ surimi $3^{\text {rd }} ; 5$ market surimi; 6 $\mathrm{LO} ; 7 \mathrm{SC} ; 8 \mathrm{CR}$; (b) St. broad range molecular weight standard; 1 minced fish; 2 surimi $3^{\text {rd }} ; 3$ surimi with WPC; 4 surimi with WPI; 5 surimi with SPI; 6 surimi with $\mathrm{FM} ; 7$ surimi with $1 \% \mathrm{FP}$; 8 surimi with $3 \% \mathrm{FP}$ (for abbreviations refer to Figure 4.6 ) ..... 118

Tigure 4.17 Stacked plot of deconvolved FTIR/ATR spectra of different cryoprotectants (top); percentage of $\alpha$-helix, $\beta$-sheet structures and their ratio (bottom): whey protein isolate (WPD), flaxseed protein (FP), flaxseed meal (FM), soy protein isolate (SPI), whey protein concentrate (WPC) 
Figure 4.18 Stacked plot of deconvolved FTIR/ATR spectra of minced fish during storage at $4^{\circ} \mathrm{C}$ and after 6 mo at $-20^{\circ} \mathrm{C}$ (top); percentage of $\alpha$-helix, $\beta$-sheet structures and their ratio (bottom)

Tigure 4.19 Stacked plot of deconvolved FTIR/ATR spectra of surimi $1^{\text {st }}$ during storage at $4^{\circ} \mathrm{C}$ and after 6 mo at $-20^{\circ} \mathrm{C}$ (top); percentage of $\alpha$-helix, $\beta$-sheet structures and their ratio (bottom)

Figure 4.20 Stacked plot of deconvolved FTIR/ATR spectra of surimi $2^{\text {nd }}$ during storage at $4^{\circ} \mathrm{C}$ and after $6 \mathrm{mo}$ at $-20^{\circ} \mathrm{C}$ (top); percentage of $\alpha$-helix, $\beta$-sheet structures and their ratio (bottom)

Figure 4.21 Stacked plot of deconvolved FTIR/ATR spectra of surimi $3^{\text {rd }}$ during storage at $4^{\circ} \mathrm{C}$ and after $6 \mathrm{mo}$ at $-20^{\circ} \mathrm{C}$ (top); percentage of $\alpha$-helix, $\beta$-sheet structures and their ratio (bottom) ............

Figure 4.22 Stacked plot of deconvolved FTIR/ATR spectra of market surimi during storage at $4^{\circ} \mathrm{C}$ and after $6 \mathrm{mo}$ at $-20^{\circ} \mathrm{C}$ (top); percentage of $\alpha$-helix, $\beta$-sheet structures and their ratio (bottom) $\quad \ldots \ldots \ldots \ldots . . .128$

Figure 4.23 Stacked plot of deconvolved FTIR/ATR spectra of lobsterflavored market surimi during storage at $4^{\circ} \mathrm{C}$ and after 6 mo at $-20^{\circ} \mathrm{C}$ (top); percentage of $\alpha$-helix, $\beta$-sheet structures and their ratio (bottom)

Figure 4.24 Stacked plot of deconvolved FTIR/ATR spectra of scallopflavored market surimi during storage at $4^{\circ} \mathrm{C}$ and after $6 \mathrm{mo}$ at $-20^{\circ} \mathrm{C}$ (top); percentage of $\alpha$-helix, $\beta$-sheet structures and their ratio (bottom)

Figure 4.25 Stacked plot of deconvolved FTIR/ATR spectra of crab-flavored market surimi during storage at $4^{\circ} \mathrm{C}$ and after 6 mo at $-20^{\circ} \mathrm{C}$ (top); percentage of $\alpha$-helix, $\beta$-sheet structures and their ratio (bottom)

Tigure 4.26 Stacked plot of deconvolved FTIR/ATR spectra of surimi with added whey protein concentrate during storage at $4^{\circ} \mathrm{C}$ and after 6 mo at $-20^{\circ} \mathrm{C}$ (top); percentage of $\alpha$-helix, $\beta$-sheet structures and their ratio (bottom)

Figure 4.27 Stacked plot of deconvolved FTIR/ATR spectra of surimi with added whey protein isolate during storage at $4^{\circ} \mathrm{C}$ and after 6 mo at $-20^{\circ} \mathrm{C}$ (top); percentage of $\alpha$-helix, $\beta$-sheet structures and their

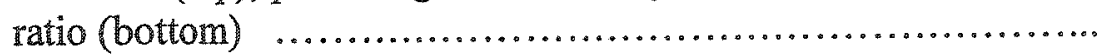


Figure 4.28 Stacked plot of deconvolved FTR ATR spectra of surimi with added soy protein isolate during storage at $4^{\circ} \mathrm{C}$ and after 6 mo at $-20^{\circ} \mathrm{C}$ (top); percentage of $\alpha$-helix, $\beta$-sheet structures and their ratio (bottom)

Figure 4.29 Stacked plot of deconvolved FTIR/ATR spectra of surimi with added flaxseed meal during storage at $4^{\circ} \mathrm{C}$ and after 6 mo at $-20^{\circ} \mathrm{C}$ (top); percentage of $\alpha$-helix, $\beta$-sheet structures and their ratio (bottom)

Figure 4.30 Stacked plot of deconvolved FTIR/ATR spectra of surimi with added $1 \%$ flaxseed protein during storage at $4^{\circ} \mathrm{C}$ and after $6 \mathrm{mo}$ at $-20^{\circ} \mathrm{C}$ (top); percentage of $\alpha$-helix, $\beta$-sheet structures and their ratio (bottom)

Figure 4.31 Stacked plot of deconvolved FTIR/ATR spectra of surimi with added $3 \%$ flaxseed protein during storage at $4^{\circ} \mathrm{C}$ and after $6 \mathrm{mo}$ at $-20^{\circ} \mathrm{C}$ (top); percentage of $\alpha$-helix, $\beta$-sheet structures and their ratio (bottom)

Figure 4.32 Percent change in the ratio of $\alpha$-helix to $\beta$-sheet structures after 6 mo storage at $-20^{\circ} \mathrm{C}$ compared to time 0 , for control (surimi $3^{\text {rd }}$ ) and surimis with different added cryoprotectants: surimi $3^{\text {rd }}(\mathrm{S} 3)$, whey protein concentrate (WPC), whey protein isolate (WPI), soy protein isolate (SPI), flaxseed meal (FM), flaxseed protein at $1 \%$ (FP 1\%), flaxseed protein at 3\% (FP 3\%) 


\section{List of Tables}

Table 2.1 Characteristic amide I band frequencies of protein secondary structures (From Stuart, 1997)

Table 3.1 Molecular weight and presumptive identification of bands present in SDS-PAGE patterns of minced fish, surimi, wash

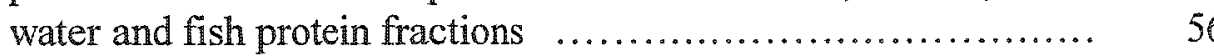

Table 3.2 Parameters measured during surimi preparation $\ldots . . . . . . . . . . . . \quad 59$

Table 3.3 Molecular weights and presumptive identification of bands present in native-PAGE electrophoretic patterns of minced fish and surimi

Table 3.4 Molecular weights and presumptive identification of bands present in SDS-PAGE electrophoretic patterns of minced fish and surimi

Table 4.1 Parameters measured during surimi preparation 


\section{Abbreviations}

\begin{tabular}{|c|c|}
\hline ATR & attenuated total reflectance \\
\hline $\mathrm{CR}$ & crab-flavored surimi \\
\hline $\mathrm{DSC}$ & differential scanning calorimetry \\
\hline $\mathrm{FP}^{\mathrm{P}}$ & flaxseed protein \\
\hline FM & flaxseed meal \\
\hline $\mathbb{F T I R}$ & Fourier transform infrared \\
\hline $\mathrm{g}$ & gram \\
\hline$\Delta \mathrm{H}$ & change in enthalpy \\
\hline HIMW & high molecular weight \\
\hline h & hour \\
\hline $\mathbf{k g}$ & kilogram \\
\hline LO & lobster-flavored surimi \\
\hline MHC & myosin heavy chain \\
\hline $\min$ & minute \\
\hline mil & milli-liter \\
\hline MLC & myosin light chains \\
\hline mo & month \\
\hline $\mathbf{M W}$ & molecular weight \\
\hline Native-PAGE & native polyacrylamide gel electrophoresis \\
\hline $\mathbb{R P M}$ & revolutions per minute \\
\hline $\mathbb{s}$ & second \\
\hline $\mathrm{SC}$ & scallop-flavored surimi \\
\hline SDS-PAGE & sodium dodecyl sulfate-polyacrylamide gel electrophoresis \\
\hline SPI & soy protein isolate \\
\hline Td & temperature of denaturation \\
\hline WPC & whey protein concentrate \\
\hline WPI & whey protein isolate \\
\hline & year \\
\hline
\end{tabular}




\section{Chapter 1}

\section{INTRODUCTION}

\subsection{General}

Surimi is one of the value-added seafood products from minced fish (wasted fish flesh recovered after deboning); minced fish is washed to remove water-soluble proteins, then mixed with cryoprotectants to extend its frozen shelf life. The surimi industry is expanding rapidly due to the fact that surimi has a relatively long shelf life and is a functional protein ingredient with good nutritional quality (Lee, 1986). Surimi is easily mass-produced, and there is a constant supply of raw materials for its production due to the abundance of under-utilized fish species.

Generally, any fish with good gel forming ability and white meat color can be used to make surimi. Alaska pollock (Theragra charcogramma) represents the largest fishery biomass used for surimi production and the largest global whitefish catch worldwide (Lee, 1984; Morrissey and Tan, 2000).

Fish quality deteriorates rapidly if fish are poorly handled and not stored properly. Each year, over 91 million tons of fish are harvested, of which $29.5 \%$ is transformed into fishmeal. Possibly, more than $50 \%$ of the remaining fish tissue is considered to be processing waste and not used as food (Kristinsson and Rasco, 2000); there is therefore an increased need to utilize our sea resources more effectively.

The consumption and popularity of seafoods has consistently increased during recent years since seafoods are increasingly recognized as important sources of nutrients for human health. Protein, lipids and bioactive components from seafoods 
have unique characteristics that differ from those of land animals (Shahidi, 1997). The main chemical components of fish meat are water, crude protein, and lipids, which together make up about $98 \%$ of the total mass of the flesh. These components have substantial impact on the nutritive value, functional properties, sensory quality, and storage stability of the meat. The nutritive value of fish proteins is relatively high because of the favorable essential amino acid pattern (Sikorski et al., 1990b).

Muscle proteins can be divided into three major groups based on their solubility: sarcoplasmic proteins (water-soluble), myofibrillar proteins (salt-soluble), and stromal proteins (insoluble). Of the three groups, myofibrillar proteins play the most critical role during processing and are responsible for functional properties such as gel forming ability (Xiong, 1997).

The seafood processing industry is an extremely important component of the Canadian food industry. However, there are several major problems facing the growth of this industry including increasing environmental concerns about dumping of fish wastes. Therefore, it is necessary to investigate the use of under-utilized fish species, which are cheaper and in greater abundance, as well as the use of fish processing wastes. Waste products could be incorporated into battering and breading production lines to create value-added seafood products, resulting in increased profits. Value addition may also result in different flavors that are usually associated with more expensive fish and seafood products (Roessink, 1989). 


\subsection{Rationale and Objectives of Study}

One of the major problems facing the growth of the seafood industry is the method of storage and distribution of products. To date, freezing is the only method of long-term storage to ensure keeping quality and to extend shelf life (Roessink, 1989). However, during frozen storage of fish muscle, denaturation and/or aggregation of myofibrillar proteins cause a loss of functional properties. Frozen storage prevents microbial spoilage and minimizes the rate of biochemical reactions in muscle, but changes in functional properties can occur at low temperatures (Park et al, 1987).

The use of cryoprotectants to extend the shelf life of leached fish minces, i.e., the development of surimi, has been an important technological development in the seafood industry. At present, the most commonly used cryoprotectants are sucrose, sorbitol, and a small amount of phosphates. These cryoprotectants have been chosen for their effectiveness, low cost, availability, and low tendency to cause Maillard browning. There is, however, interest in identifying alternative cryoprotectants and blends for specific applications, which have improved ability to stabilize myofibrillar proteins, and to reduce sweetness (MacDonald et al., 2000).

The freezing rate, frozen storage temperature, steadiness of storage conditions, and thawing conditions significantly affect the quality of frozen surimi. It is desirable to prevent the formation of large ice crystals in frozen surimi during the freezing process (Matsumoto and Noguchi, 1992). However, published comparative studies of rapid and slow freezing rates are very limited so far. 
The overall objective of this research therefore was to investigate protein changes in Alaska pollock during preparation and storage of surimi, and to study the role of potential cryoprotectants on protein changes during storage.

The specific objectives of the research were:

1) To optimize a method for surimi preparation considering the effects of rinsing conditions and the number of washing cycles on the quality of surimi.

2) To investigate the changes in protein structure of minced fish and surimi during preparation and storage of surimi, using electrophoresis, FTIR/ATR spectroscopy, and DSC.

3) To determine the effect of freezing rate on the shelf life stability of the product, and to study the effect of rapid freezing on the biochemical and physical properties of fish proteins compared to slow freezing.

4) To investigate the role of incorporation of different cryoprotectants on the quality of surimi during frozen storage.

5) To monitor the effects of cryoprotectants on protein changes at $4^{\circ} \mathrm{C}$ when compared to frozen storage at $-20^{\circ} \mathrm{C}$. 


\section{Chapter 2}

\section{LITERATURE REVIEW}

\subsection{Nitrogenous Components of Fish Muscle}

\subsubsection{Total Contents and Composition}

The nitrogenous components of fish muscle mainly include proteins, peptides, nucleic acids, nucleotides, trimethylamine (TMA) and its oxide (TMAO), free amino acids, and urea. The flesh of fish contains usually from 11 to $24 \%$ crude protein $(1.76$ to $3.84 \%$ total nitrogen), depending on the species (Sikorski et al., 1990b).

Fish muscle proteins are less stable to frozen storage than muscle proteins from other vertebrates such as poultry and mammals. It has been proposed that such differences could be attributed to the fact that fish are cold-blooded animals, while poultry and mammals are warm-blooded (MacDonald and Lanier, 1991).

The proteins of fish muscle can be categorized into the following three major groups: (1) the components of the sarcoplasmic fraction which perform the biochemical tasks in the cells, (2) the myofibrillar proteins of the contractive system, and (3) the proteins of the connective tissues, responsible mainly for the integrity of the muscles. A schematic diagram of fish muscle protein composition is shown in Figure 2.1.

Figure 2.2 shows the structural organization of fish fillet. The fish fillet is divided into blocks of muscle known as myotomes, separated by collagenous myocomata. The collagen of the myocomata is denatured on cooking and the myotomes may separate, thus forming the flakes of the cooked fish. The fish muscle 
Total crude protein in fish muscle

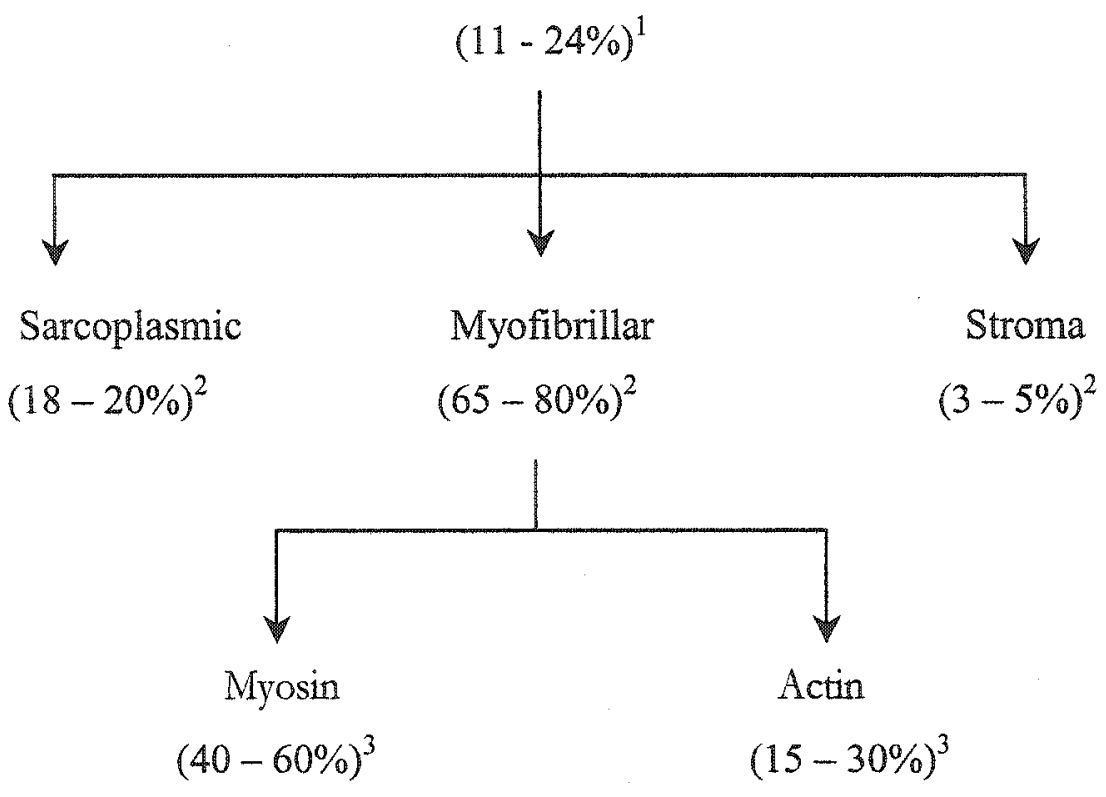

Figure 2.1: Schematic diagram of fish muscle protein composition. ${ }^{1}$ (Sikorski et al., 1990b); ${ }^{2}$ (Hall and Ahmad, 1997); ${ }^{3}$ (Mackie, 1993). 


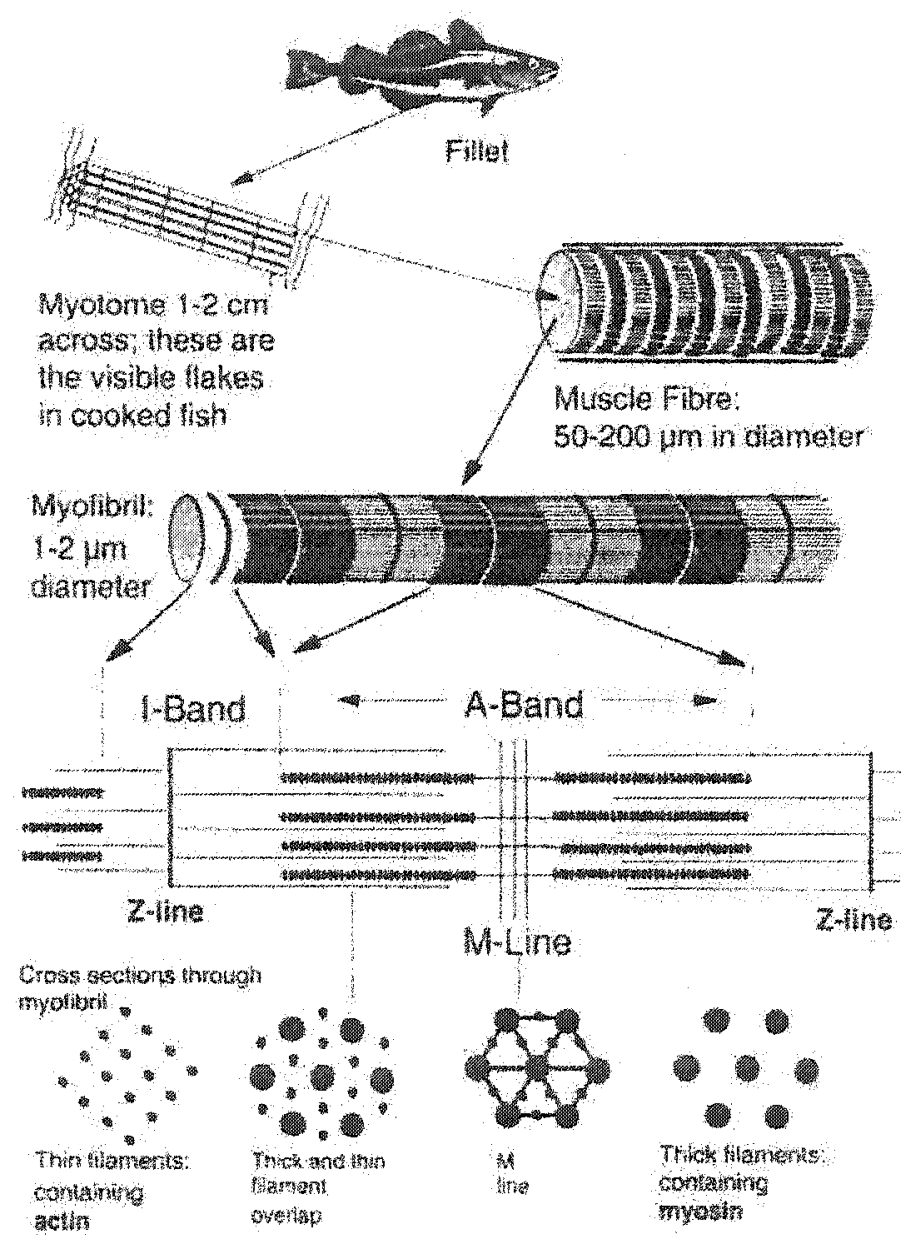

Figure 2.2: The structural organization of fish fillet (from Goodband, 2002). 
fibers stretch between adjacent myocomata. Within the muscle fibers are the myofibrils, the contractile elements of the muscle. The myofibrils consist of thick filaments of myosin and thin filament of actin. The arrangement of these filaments gives muscle its banding pattern, as shown in Figure 2.2. The repeating unit of the myofibrils, the distance between two Z-lines, is known as a sarcomere (Goodband, 2002).

\subsubsection{The Sarcoplasmic Proteins}

The sarcoplasmic, or water-soluble, proteins make up 18 to $20 \%$ of total muscle proteins (Hall and Ahmad, 1997). They are normally found in the cell plasma where they act as enzymes and oxygen carriers. These proteins are heat sensitive and precipitate on cooking and do not contribute significantly to the texture of fish. The oxygen storage protein, myoglobin, is found in this fraction and it is believed to contribute to the oxidative changes within the flesh (Mackie, 1993).

\subsubsection{The Myofibrillar Proteins}

Myofibrillar proteins, the largest proportion of fish muscle proteins, account for 65 to $80 \%$ of total protein. They give the muscle its fibre-like structure (Hall and Ahmad, 1997). These proteins can be extracted from the comminuted fish with neutral salt solutions of ionic strength ranging from 0.30 to 1.0 . The myofibrillar proteins participate in the postmortem stiffening of the tissues (rigor mortis). Changes in these proteins lead to resolution of the stiffness; during long-term frozen storage they may cause toughening of the meat. The myofibrillar proteins are mainly responsible for the 
water-holding capacity of fish, for the characteristic texture of fish products, as well as for the functional properties of fish minces and homogenates, especially the gelforming ability (Sikorski et al., 1990b).

The major components of myofibrillar proteins are myosin, actin, tropomyosin, and troponin.

Myosin: Myosin with MW of about $500 \mathrm{kDa}$ makes up 40 to $60 \%$ of the myofibrillar fraction (Mackie, 1993). Myosin is a long, linear molecule made up of two identical heavy chains (MHC) of MW of $200 \mathrm{kDa}$ and four light chains (MLC) of MW $\approx 20 \mathrm{kDa}$ each. The two heavy chains have a high degree of $\alpha$-helical content and are wound around each other in a super-coiled helical conformation and form the rod portion (Figure 2.3 a). The globular regions are responsible for ATPase activity and contain actin-binding sites.

Myosin is a relatively large molecule that can be cleaved into several fragments. Myosin heavy chain can be cleaved by papain near the globular end of the rod, to produce fragment 1 (S-1) (Visessanguan et al., 2000). When myosin is digested with trypsin, two major fragments are obtained. The largest fragment is heavy meromyosin containing both myosin globular heads and a portion of the myosin rod. The other major fragment is light meromyosin, which is the helical rod portion of the myosin molecule. Further proteolytic digestion of heavy meromyosin yields the $\mathrm{S}-1$ fragment, the individual myosin head, and the S-2 fragment, the small portion of myosin rod (Figure 2.3 b) (Rattrie and Regenstein, 1997). 


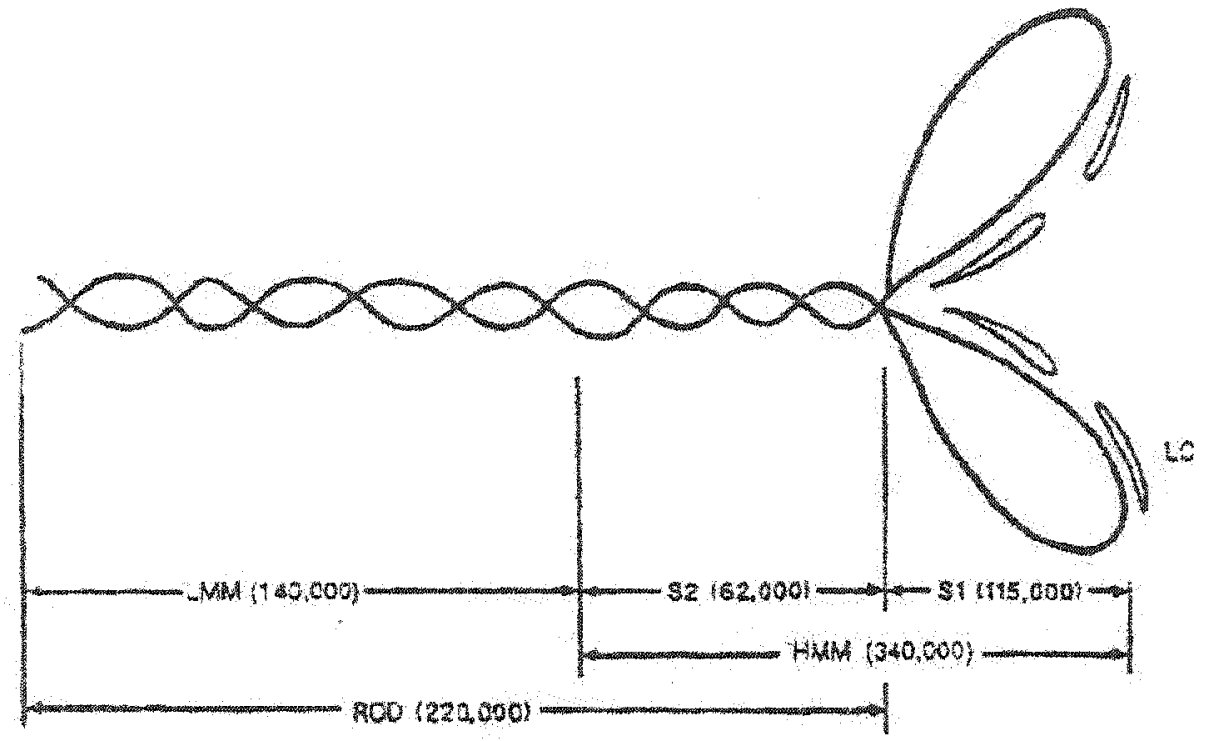

(a)

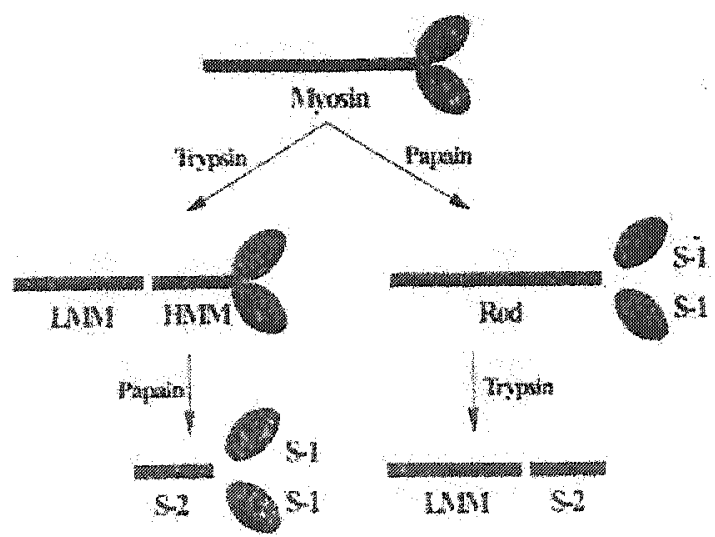

(b)

Nigure 2.3: Schematic diagram of (a) the myosin molecule and (b) its subfragments (from Mackie, 1993 and Visessanguan et al., 2000). 
Actim: Actin comprises 15 to $30 \%$ of the total myofibrillar protein content of fish muscle (Mackie, 1993). The water-extractable actin, which can be obtained from the acetone-dried powder of the purified myofibrillar fraction, is in the monomeric form called globular actin (G-actin) with MW of $43 \mathrm{kDa}$. It polymerizes in the presence of neutral salts and forms actin filaments referred to as fibrous actin ( $F$-actin), which has a double helical structure. When minced fish meat is treated with neutral salt solutions, actin is extracted together with myosin in the form of actomyosin. Like myosin, this complex exhibit the $\mathrm{Ca}^{2+}$ activated ATPase characteristics but is also activated by $\mathrm{Mg}^{2+}$ (Sikorski et al., 1990b).

Tropomyosin and the Troponins: Tropomyosin and the troponins together account for $10 \%$ of the myofibrillar proteins. Tropomyosin with $\mathrm{MW}$ of about $66 \mathrm{kDa}$, is a dimeric molecule consisting of two subunits designated $\alpha$ - and $\beta$-tropomyosin with MW of about 34 and $36 \mathrm{kDa}$, respectively. Troponin is a complex protein comprised of three subunits designated $\mathrm{T}, \mathrm{I}$ and $\mathrm{C}$ with $\mathrm{MW}$ of 31,21 , and $18 \mathrm{kDa}$, respectively. Troponin $\mathrm{T}$ is the major site for binding troponin to tropomyosin; troponin $\mathrm{C}$ binds calcium; troponin I inhibits the enzymic activity of actomyosin.

C-protein: C-protein with $\mathrm{MW}$ of $135 \mathrm{kDa}$ is located in the thick filament. It is often a contaminant in myosin preparations (Mackie, 1993); C-protein is relatively high in proline content, which explains why the protein contains little or no $\alpha$-helical structures (Xiong, 1997). 
a-Actinim: The major protein found in the Z-disk is $\alpha$-actinin with MW of about $95 \mathrm{kDa}$. It contains a large amount of $\alpha$-helical structure and a relatively high content of charged residues (Mackie, 1993; Xiong, 1997).

\subsubsection{The Proteins of the Stroma}

The residue obtained after extraction of the sarcoplasmic and myofibrillar proteins is called the stroma, and is composed of the main connective tissue proteins (collagen, reticulin, and elastin). The proteins of the stroma comprise about 3 to $5 \%$ of the total protein and are easily solubilized by cooking (Hall and Ahmad, 1997). The collagens of fish muscle have lower melting temperatures than mammalian muscle and are easily converted to gelatin on cooking (Goodband, 2002).

\subsection{The Functional Properties of Fish Protein}

The total quality of fish as food depends on the nutritive value of the meat, its sensory attributes, and the functional properties, i.e., on the ability to contribute to the desirable sensory characteristics of food products by interactions with water and other food components. In fish flesh, the functional properties depend mainly on the proteins. The functional properties attributed to proteins of the fish flesh consist of hydration, which is reflected in solubility, dispersibility, water retention, swelling, and gelforming ability, as well as interaction with lipids, i.e., emulsifying capacity and emulsion stability. These properties depend on the composition and conformation of proteins. They change during storage and processing of the fish (Sikorski et al., 1990a). 


\subsubsection{Formation of Gel Structure}

Protein gels can be defined as "three-dimensional matrices or networks in which polymer-polymer and polymer-solvent interactions occur in an ordered manner resulting in the immobilization of a large amount of water by a small proportion of protein" (Mulvihill and Kinsella, 1987).

Ferry (1948) proposed that, in general, formation of protein gels involves the following mechanisms:

$$
X P_{N} \rightarrow X P_{D} \rightarrow\left(P_{D}\right) X
$$

where $\mathrm{X}$ is the number of protein molecules, $\mathrm{P}_{\mathrm{N}}$ is the native protein, and $\mathrm{P}_{\mathrm{D}}$ is denatured protein. According to this, gelation is a two-step process involving denaturation and aggregation. Denaturation is a process in which native proteins undergo conformational changes including alterations of hydrogen bonding, hydrophobic interactions, and ionic linkages (Mulvihill and Kinsella, 1987). The subsequent process is aggregation in which denatured protein molecules align themselves and interact with each other at specific points to form a three dimensional network.

The formation of a myofibrillar protein network is responsible for the functional properties of surimi. It is this gel structure that brings about the elasticity and the textural strength of the product. The grinding of fish with no salt added does not disrupt the myofibrillar structure (Sato et al., 1987). When fish meat is minced with salt, disintegration of the myofibrillar structure and formation of an actomyosin network are observed (Sato et al., 1987; Pan, 1986). 
Setting of the mince at below-ambient temperature enhances the unfolding of protein helices and the interaction between the hydrophobic side chains, resulting in a more uniform and thicker network as compared to those minced fish that skip setting before heating (Sato et al., 1987; Niwa, 1975).

Formation of firm gel network requires a balance between the protein-protein and protein-water interactions. Hydrophobic interactions and disulfide linkages are the major forces that account for the integrity and strength of the gel network (Itoh et al., 1979). Addition of cysteine or sodium bisulfite to the mince produced from frozen fish results in the recovery of reactive and total sulflydryl groups and improves the gel strength of the minced fish products (Lan et al., 1987). Denaturation and interactions between the heavy chains reduce gel-forming capacity and lower the surimi quality (Numakura et al., 1987).

\subsubsection{The Hydration of Proteins}

The ability of fish meat to retain water plays a critical role in palatability and consumer acceptance of the product and is usually referred to as water-holding capacity. Changes in $\mathrm{pH}$ as well as denaturation and aggregation during frozen storage and processing may cause an undesirable decrease in solubility and thus deterioration of other functional properties of the proteins.

The water-retaining properties of fish flesh can be measured in different ways, mainly as the loss of juice from a sample due to, for example, pressing or centrifugation, or as the water-binding capacity, i.e., the amount of water bound by comminuted meat with added water, as measured in the pellet after centrifugation 
(Regenstein and Regenstein, 1984). Hydration in fish muscle depends on many factors, especially the characteristics of the proteins, $\mathrm{pH}$, the concentration of postmortem metabolites and added salts, as well as the changes in the proteins due to storage and processing. Many aspects of the water-holding capacity of fish meat have been investigated and discussed by Hamm (1960 and 1986), while water retention in fish flesh has been presented by Regenstein and Regenstein (1984).

\subsubsection{Emulsifying Properties}

The interaction of fish proteins with lipids is especially important in fish sausages, as high emulsifying capacity and emulsion stability is required in the sausage batters. These attributes as well as other functional properties have a special impact on the quality of fish protein concentrates and preparations which are intended to be used as structure forming components of different food products (Kinsella, 1976; Sikorski and Naczk, 1981).

\subsection{Postharvest Biochemical Changes in Fish Muscle}

In considering the effects of frozen storage on the proteins of muscle it is important to recognize that from the moment of death, a whole series of biochemical changes is initiated in fish. The major event is the cessation of circulation of blood, which means that oxygen is no longer supplied to the tissue, resulting in a decrease in the ATP concentration and initiating glycolysis, and eventually contraction of muscle through the interaction of the thick and thin filaments (Mackie, 1993). 
The catabolic processes taking place in a dead fish body lead to stiffening of the muscles known as rigor mortis. The stiffness of a fish in rigor is a sure sign of freshness. However, it may have an adverse effect on the suitability of the fish for mechanical or even hand facilitating. After several hours, the rigid fish gradually softens, although the extension of the muscles under stress is not reversible and the muscle has no ability to respond to electrical stimuli. The biochemical state of the postrigor muscles is different from that of the prerigor flesh. The postrigor fish does not display the signs of prime freshness (Sikorski et al., 1990a).

The quality of fish, regardless of the species characteristics, is affected both by the freshness and the appearance of the fillet. The biochemical and biophysical processes involved in rigor may, however, influence the appearance of the fillet and the amount of fluid lost due to freezing/thawing and cooking. Fish entering rigor at high ambient temperatures lose much drip on thawing and may be tough and stringy after cooking (Stroud, 1969).

The time for the onset of rigor depends upon a number of factors such as the species of animal, its physiological condition, and the temperature of storage postmortem. When muscle is removed from the skeleton at the prerigor stage, rigor mortis may result in extreme contraction causing unacceptable toughness. On the other hand, if it is rapidly frozen and stored, rigor mortis can develop on thawing. Thus, processing of fish is often delayed until rigor has been resolved (Mackie, 1993). 


\subsection{Surimi Composition and Preparation}

Surimi is stabilized myofibrillar proteins obtained from mechanically deboned fish flesh that is washed with water and blended with cryoprotectants (Park and Morrissey, 2000). Surimi is an intermediate product used in a variety of products, ranging from the traditional kamaboko products of Japan to surimi seafoods or shellfish substitutes.

Conventional surimi is refined myofibrillar proteins processesd by removing unnecessary foreign materials. However, a newly developed acid-aided surimi processing method has shown great potential to utilize the maximum quantity of flesh. This new process retains all sarcoplasmic proteins, but provides very functional surimi gels. However, few fundamental questions about this process remain unresolved, including the role of sarcoplasmic proteins on the strength of fish gels, and the gelation mechanism with regard to the presence of protease (Choi and Park, 2002; Kim et al, 2002; Park, 2001).

There are several steps in the surimi manufacturing process. For surimi-type products, fish should be processed soon after the onset of rigor mortis (Sonu, 1986). First, the fish are headed, gutted and cleaned in a washing tank. The fish are then run through a mechanical deboner, which separates the fish flesh from the bone and skin. Surimi is prepared from minced fish by repeated washing with water to remove various undesirable components, such as fat, blood, pigments, and odorous compounds, but more importantly, water-soluble proteins. Washing also increases the concentration of myofibrillar protein, which improves gel strength and elasticity. After washing, water is removed and the remaining fish flesh is run through a strainer to remove any residual 
skin, bone, and scale. Following the washing and dewatering, the concentration of functional actomyosin increases, which facilitates the gel-forming ability of surimi seafood. Cryoprotectants, such as sugar, sorbitol, and polyphosphate, are added at this stage to protect the fish proteins from the denaturing effect of cold temperatures.

Surimi is made from a wide variety of fish species, however most are not used to make frozen surimi. The most suitable species for surimi processing are those with white flesh and low fat content (Park and Morrissey, 2000). Fresh surimi can be made from species such as tuna, mackerel, croaker, and shark. Japanese frozen surimi is made from Alaska pollock (Theragra charcogramma), whereas in the Philippines, frozen surimi is made from big-eye snapper (Priacanthus spp.), croaker (Pennahia, Johnius spp.), and threadfin bream (Nemipterus spp.). Generally, any fish with good gel forming ability and white meat color can be used to make frozen surimi. The surimi industry mainly uses Alaska pollock for surimi production, representing 50-70\% of total surimi production.

The quality of surimi during frozen storage depends upon storage temperature, storage period, the level of remaining moisture, and the cryoprotectants used (Lee, 1984). Sucrose was the first cryoprotectant used after it was found to prevent the denaturation of muscle protein, particularly actomyosin, during frozen storage (Matsumoto, 1978). Adding polyphosphates also extends the frozen shelf life by enhancing the effects of sucrose.

Since surimi is essentially bland in flavor due to the extensive washing it receives during production, it can be formulated to have a number of different flavors, including crab, lobster, or shrimp. These shellfish analogs have been particularly 
successful due to the fact that their texture is also very similar. There are also a large number of products that can be produced from frozen surimi, including a number of breaded and battered products, such as fish cakes and fish sticks.

The largest overall benefit of surimi comes from the fact that it uses underutilized fish species, which are in abundant supply. This is extremely important since there is an over-exploitation and depletion of the world's most valuable fish stocks, despite attempts to control over-fishing (Venugopal \& Shahidi, 1994).

Biological (intrinsic) factors affecting surimi quality are the effects of species, seasonality/sexual maturity, and freshness or rigor, while processing (extrinsic) factors affecting surimi quality include harvesting, onboard handling, time/temperature of processing, washing cycle/wash water ratio, $\mathrm{pH}$ and salinity (Park and Morrissey, 2000 ). The overall process of surimi production is summarized in Figure 2.4.

\subsection{Freezing, Frozen Storage, and Thawing of Surimi}

The freezing rate, frozen storage temperature, steadiness of storage conditions, and thawing conditions strongly affect the quality of frozen surimi. It is desirable to prevent the formation of large ice crystals in frozen surimi during the freezing process. Such large ice crystals form in the critical temperature range of -1 to $-5^{\circ} \mathrm{C}$, and their formation can be prevented by rapid freezing or by minimizing the time in which the product remains in this critical temperature range (Matsumoto and Noguchi, 1992). 


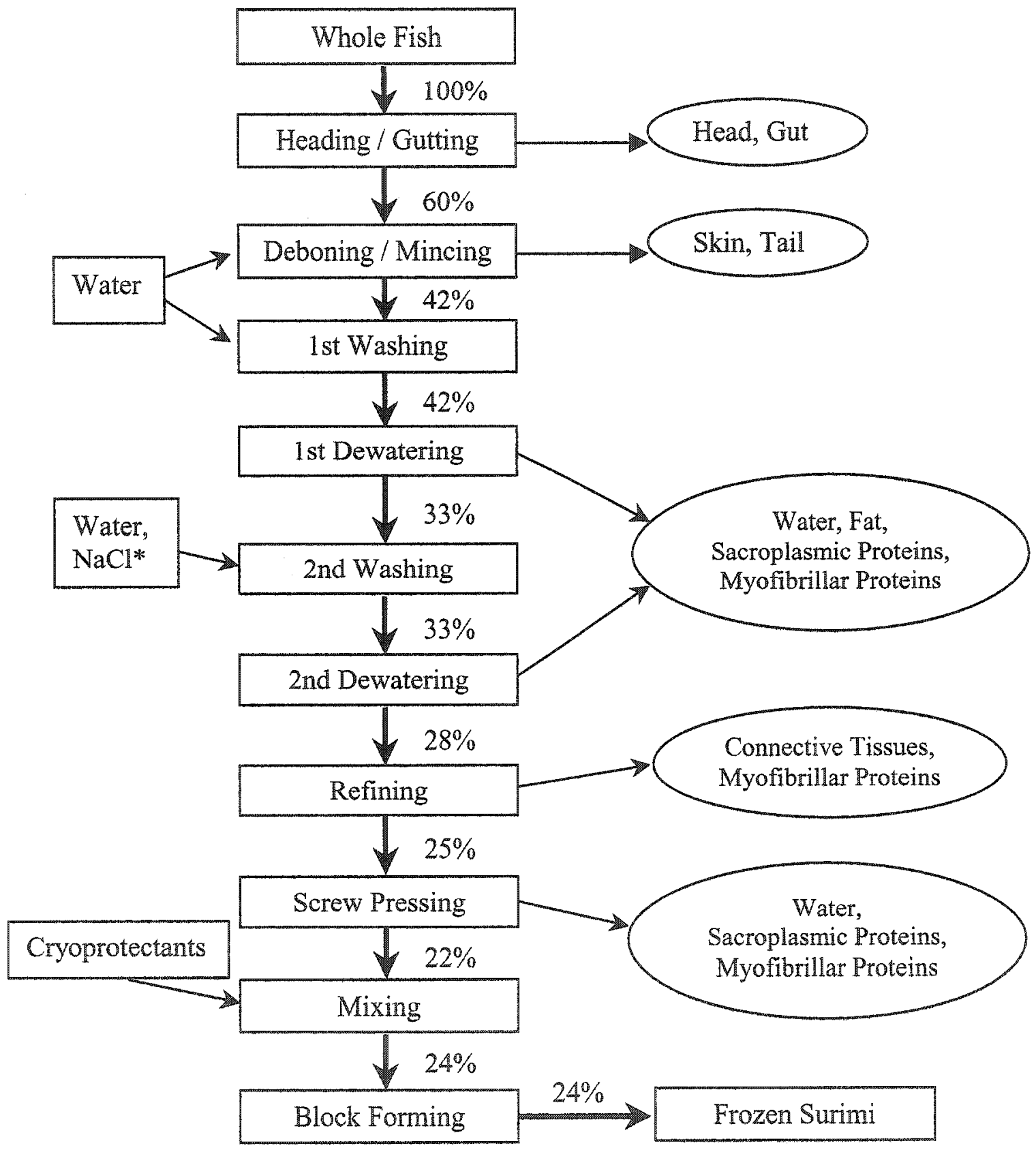

Figure 2.4: Flow diagram of surimi manufacturing process with estimated yield. $\mathrm{NaCl}$ : $\mathrm{NaCl}$ can be added for better removal of water (from Park et al., 1997). 
The stability and shelf life of surimi depend also upon the frozen storage conditions. The gel strength of surimi remains very stable at $-35^{\circ} \mathrm{C}$, but is less at $-10^{\circ} \mathrm{C}$. The shelf life of surimi is longer at lower, non-fluctuating temperatures. In 1984, the Japanese Association of Refrigeration recommended that the shelf life of frozen surimi be fixed at 6-12 months at -23 to $-25^{\circ} \mathrm{C}$.

It is generally believed that storage temperature is more important than freezing rate for determining the quality of frozen fish. However, the freezing rate determines ice crystal size, locality of ice crystals, and sites of highly concentrated salt solutions, which may be linked to protein alterations (MacDonald et al., 2000).

Thawing is another important step in surimi processing and use, which can affect myofibrillar protein denaturation. Quick thawing at low temperature is recommended (Matsumoto and Noguchi, 1992).

\subsection{Freeze Denaturation of Myofibrillar Proteins}

The optimal way to achieve long-term storage of surimi is through freezing, which prevents microbial spoilage and minimizes biochemical reactions. However, after prolonged storage even at temperatures as low as $-20^{\circ} \mathrm{C}$, undesirable sensory changes in the product take place. The shelf life of fatty species is limited by oxidative changes of lipids and pigments, while the quality of lean fish is affected mainly by severe alterations of proteins, usually called denaturation.

Protein denaturation is a complex phenomenon involving alterations of the secondary and tertiary structure of proteins due to breakage of the bonds that contribute 
to the stability of the native protein conformation without rupture of the covalent linkages between carbon atoms in the polypeptide chains (Sikorski et al., 1976).

Factors causing protein denaturation include partial dehydration, inorganic salts, lipids and fatty acids and the action of formaldehyde (Sikorski et al., 1976). The degree of protein denaturation during frozen storage is affected by many factors such as the state of rigor at the time of freezing, treatment before freezing, quantity and composition of free amino acids, and adenosine-nucleotides and their derivatives (Park et al., 1997). Factors influencing protein denaturation also include salt concentration, $\mathrm{pH}$, ionic strength, surface tension, dehydration, physical damage caused by ice crystals, enzymic breakdown of trimethylamine oxide, lipids and their degradation products (Park, 1994; Mackie, 1993).

The functional properties of fish such as protein solubility and gel forming ability also change significantly during frozen storage, especially when frozen in a minced state. The thawed material has lower water holding capacity and fatemulsifying ability and is less suitable for use in the manufacture of jellied products.

The deterioration of fish proteins during frozen storage is reflected mainly by a significant decrease in solubility, which is due to alterations of the myofibrillar fraction. The sarcoplasmic proteins do not undergo significant changes. Most of the alterations occur in the myosin-actomyosin system. Myosin upon standing in solutions tends to aggregate (Sikorski et al., 1976). The properties of actin do not change significantly during prolonged frozen storage of fish (Connell, 1960).

King (1966) showed that during frozen storage of cod there is an initially rapid decrease in extractability of the F-actomyosin fraction, followed by a fairly large 
increase in the concentration of a fraction consisting of myosin and $\mathrm{G}$-actomyosin and a subsequent gradual decline of the extractability of all the investigated fractions of myofibrillar proteins. Based on this evidence, King (1966) proposed that during frozen storage of cod there was a "rapid dissociation of F-actomyosin into G-actomyosin followed by a slower rate of dissociation of $\mathrm{G}$-actomyosin into components that then aggregate to form inextractable protein" (Figure 2.5).

Many attempts have been made to discover which chemically active groups, by their interactions, cause the decrease in solubility of fish proteins at freezing temperatures. The sulfhydryl groups, the potent cross-linking agents in proteins, were reported by Connell (1964) to be "unmasked" and thus more easily reactable and accessible for chemical determination in fish myosins than in those extracted from mammals and chicken. Mao and Sterling (1970) also detected an increase of the content of ester and aldehyde groups in myosin during frozen storage at $-5^{\circ} \mathrm{C}$ for 30 days.

Several theories on protein denaturation in relation to fish and freezing damage have been formulated. One theory worthy of note is that of protein denaturation being affected by the freezing out of water. The conformation of most native proteins has the hydrophobic side chains buried inside the protein molecule. However, some of these hydrophobic side chains are exposed at the surface of the molecule itself. It has been suggested that the water molecules arrange themselves around these exposed hydrophobic side chain groups so as to minimize the energy of the oil/water interface and, at the same time, act as a highly organized barrier, which mediates the hydrophobic/hydrophilic interactions between protein molecules. These water 
molecules form a network of hydrogen bonds, which contributes to the stability of the highly organized three-dimensional structure of the proteins. As water molecules freeze out, they migrate to form ice crystals, resulting in the disruption of the organized $\mathrm{H}$ bonding system that stabilizes the protein structure. As the freezing process continues,

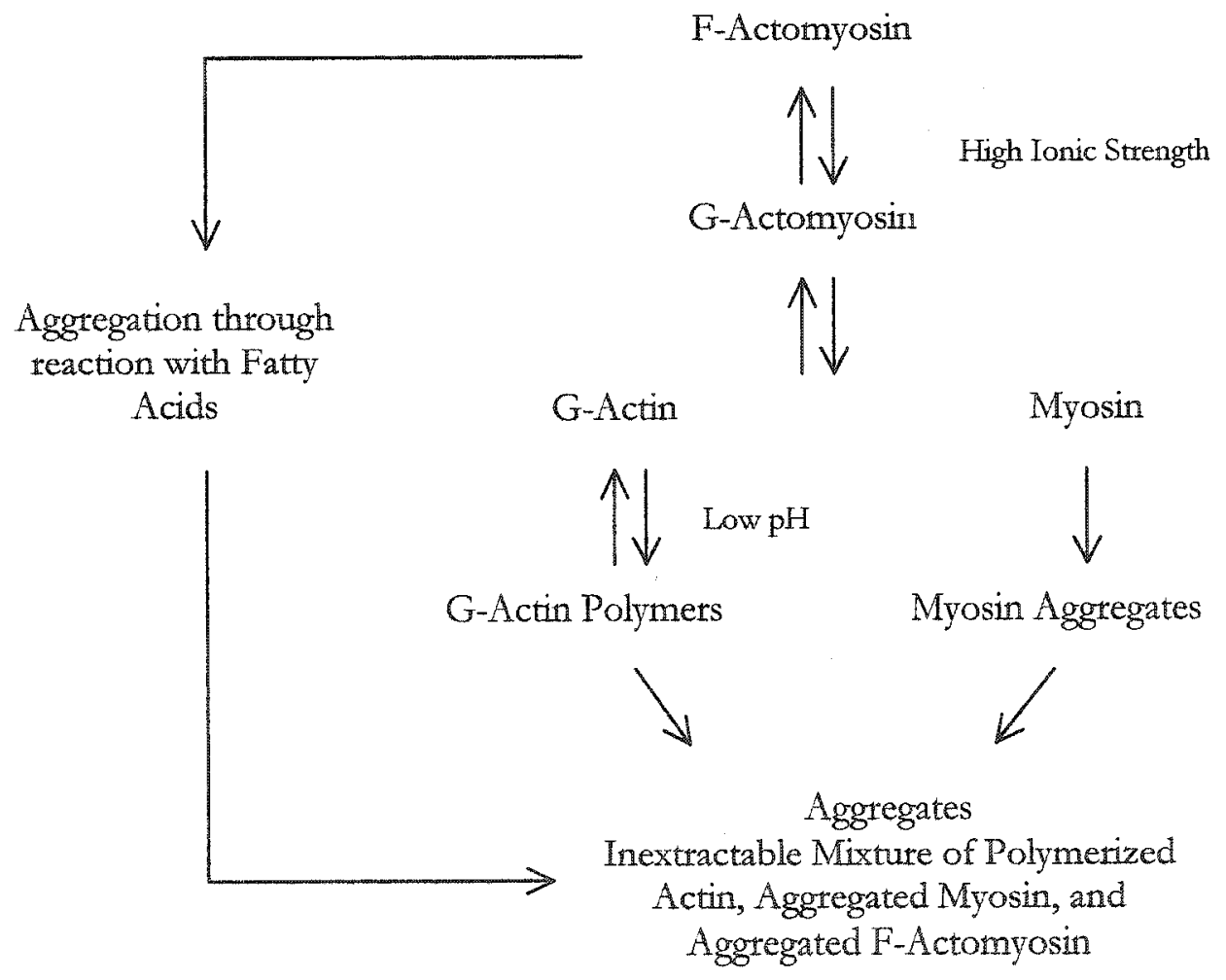

Figure 2.5: Postulated mechanism for the conversion of myofibrillar proteins into inextractable protein (from King, 1966). 
the hydrophobic as well as the hydrophilic regions of the protein molecules become exposed to a new environment, which may allow the formation of intermolecular crosslinkages either within the same protein molecule, causing deformation of the protein's three-dimensional structure, or between two adjacent molecules, leading to proteinprotein cross links. Freezing also concentrates solids, including mineral salts and small organic molecules, within the remaining unfrozen aqueous phase in the cell, which results in changes in ionic strength and possibly $\mathrm{pH}$, leading to the denaturation of the protein molecule (Figure 2.6).

\subsection{Stabilization of Protein in Surimi}

\subsubsection{Cryoprotectants}

Freeze-thaw stability is one of the functional properties of fish proteins, of prime importance to the quality of surimi products. Before 1960 , surimi was manufactured and used within a few days as a refrigerated raw material because freezing commonly deteriorated muscle proteins and induced protein denaturation, which resulted in poor functionality. Nishiya et al. (1960) discovered a technique that prevented freeze denaturation of proteins in Alaska pollock muscle. This technique required the addition of low-molecular weight carbohydrates, such as sucrose and sorbitol, to the dewatered myofibrillar proteins before freezing. The carbohydrates stabilized the actomyosin, which is highly unstable during frozen storage (Scott et al., 1988). Freezing of surimi is done commercially with the addition of sucrose (4\%), sorbitol $(4 \%)$ and polyphosphates $(0.2 \%)$, which protect fish myofibrillar proteins during long periods of frozen storage (Lee, 1984). 


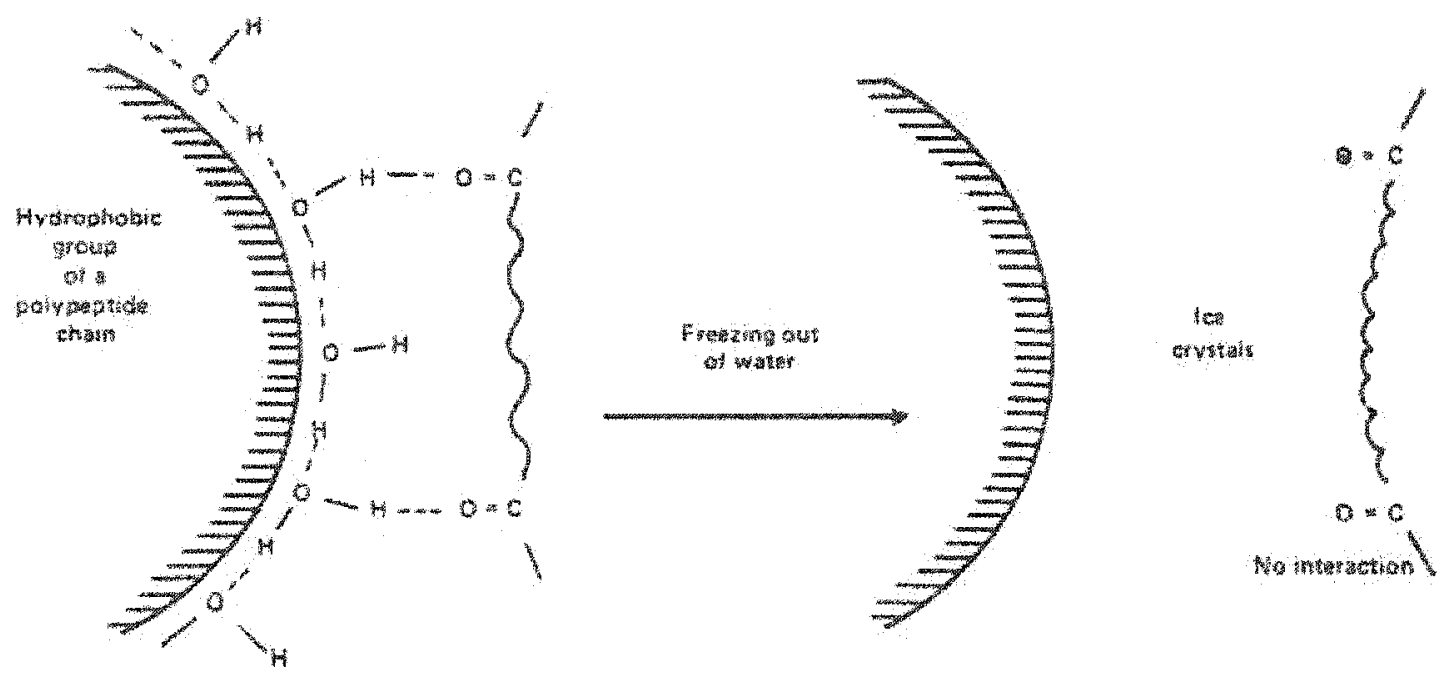

Figure 2.6: Diagramatic representation of a possible effect of freezing out of water on the water-mediated hydrophobic-hydrophilic linkage in a protein molecule (from Sikorski et al, 1976). 
One disadvantage of the commercial cryoprotectant blend used is the high level of sucrose and sorbitol, which impart a sweet taste that may be undesirable particularly to the Western consumer. Yoon and Lee (1990) reported that $4 \%$ sucrose plus $4 \%$ sorbitol in crystalline or liquid form in red hake surimi when given as extruded gel products to a sensory panel were judged to be too sweet. In addition, consumers today are concemed about caloric content, and low calorie cryoprotectants in surimi may be preferred.

Cryoprotectants applicable to minced fish products generally fall into five categories based on their chemical nature: (1) amino acids and peptides, (2) carboxylic acids, (3) mono- and disaccharides, (4) polyols, and (5) salts, mainly polyphosphates.

Many amino acids have cryoprotective effects. Among them, glutamate and aspartate are most effective (Noguchi and Matsumoto, 1970; Ohnishi et al., 1978). They prevent the actomyosin from rapid decreases in solubility, viscosity, and ATPase activity. They also keep the actomyosin molecules from forming aggregates. Amino acids having relatively large hydrophobic side chains such as leucine and phenylalanine do not have cryoprotective effects.

Malonic, maleic, lactic, malic, tartaric, gluconic, and glycolic acids are among the carboxylic acids displaying most effective cryoprotective effects (Noguchi and Matsumoto, 1975).

Hexoses (glucose and fructose), and disaccharides (sucrose and lactose) are very effective. It has become a standard industrial practice to include sucrose in the surimi formulation to prevent freezing denaturation of fish muscle proteins. Reducing sugars may cause browning during processing and storage. 
Carvajal et al. (1999) revealed the ability of maltodextrins of varying mean molecular weight (versus sucrose or a sucrose-sorbitol mixture) to stabilize Alaska. pollock surimi proteins to the denaturing effects of frozen storage. Furthermore, highly concentrated branched oligosaccharides were used as cryoprotectants for surimi by other researchers (Auh et al., 1999).

Polyols, especially glycerol, have long been used as biological cryoprotectants. Glycerol, ethylene glycol, and sorbitol, which have been considered as humectants in food processing, are effective cryoprotectants for surimi processing. Additions of $10 \%$ sorbitol and 1.5 to $3 \%$ glutamate to horse mackerel mince show a synergistic effect on upgrading the gel strength of the end products (Noguchi et al., 1976).

Salt, such as sodium chloride, is a primary ingredient in fish mince. However, it is used to solubilize the actomyosin and to season the flavor. It does not serve as a cryoprotectant. Polyphosphates are widely used to improve water-holding capacity and to reduce thaw drip. Tripolyphosphates, pyrophosphates, and hexametaphosphates are more effective than orthophosphate. Mixtures of tripolyphosphate and pyrophosphate or of either phosphate or sugar are effective in improving water retention and gel strength (Noguchi et al., 1975; Matsumoto and Noguchi, 1971).

Several mechanisms of how cryoprotectants prevent protein denaturation during frozen storage have been proposed. Since all substances with cryoprotective effects on fish protein have more than two functional groups, Tsuchiya et al. (1975) suggested the following mechanisms:

To show a positive cryoprotective effect, the molecule must have one essential group, $-\mathrm{COOH},-\mathrm{OH}$, and one or two complementary groups, such as $-\mathrm{COOH},-\mathrm{OH}$, 
$-\mathrm{NH}_{2},-\mathrm{SH}_{9}-\mathrm{SO}_{3} \mathrm{H}$. Di- or tri- $\mathrm{PO}_{4} \mathrm{H}_{2}$ groups function as both essential and complementary groups.

A cryoprotective substance might be bound to protein molecules by one of the functional groups via either ionic, hydrogen or -S-S- bonds, while the other functional group(s) may be hydrated, resulting in an increase in hydration and in net charge of the protein. This may increase the electrostatic intermolecular repulsion and hydration of proteins, and then protect the protein molecules from dehydration during frozen storage.

Back et al. (1979) indicated that proteins are stabilized by a combination of hydrogen bonding, electrostatic interactions, and hydrophobic interactions. These researchers showed that sugars induce reorientation and rearrangement of the water molecules that surround them. The results supported the hypothesis that the dominant mechanism by which sugars and polyols stabilize proteins against heat denaturation is through their effect on the structure of water, which determines the strength of hydrophobic interactions. They concluded that hydrophobic interactions make the major contribution to protein structure stabilization, while hydrogen bonding and electrostatic interactions have relatively small effects.

Based on densitometric determination of protein/sugar/water solutions, Arakawa and Timasheff (1982) concluded that the denatured structure of proteins is thermodynamically less favorable in sugar solution than in water. This theory involves the increase of hydration of protein molecules in sugar-added water. 
Figure 2.7 illustrates a proposed model for the aggregation process of proteins during frozen storage and the mechanism of the function of the cryoprotectants with respect to such aggregation. As the muscle is cooled below the freezing point, the water molecules in the cooler locations of the muscle start to crystallize. Water molecules located elsewhere migrate to the ice crystals, resulting in their growth. The growth of ice crystals accompanies the removal of water from the environment around the protein molecules, causing the surface functional groups to become dehydrated and free, which allows the intermolecular bonds between the functional groups to form (Matsumoto, 1980).

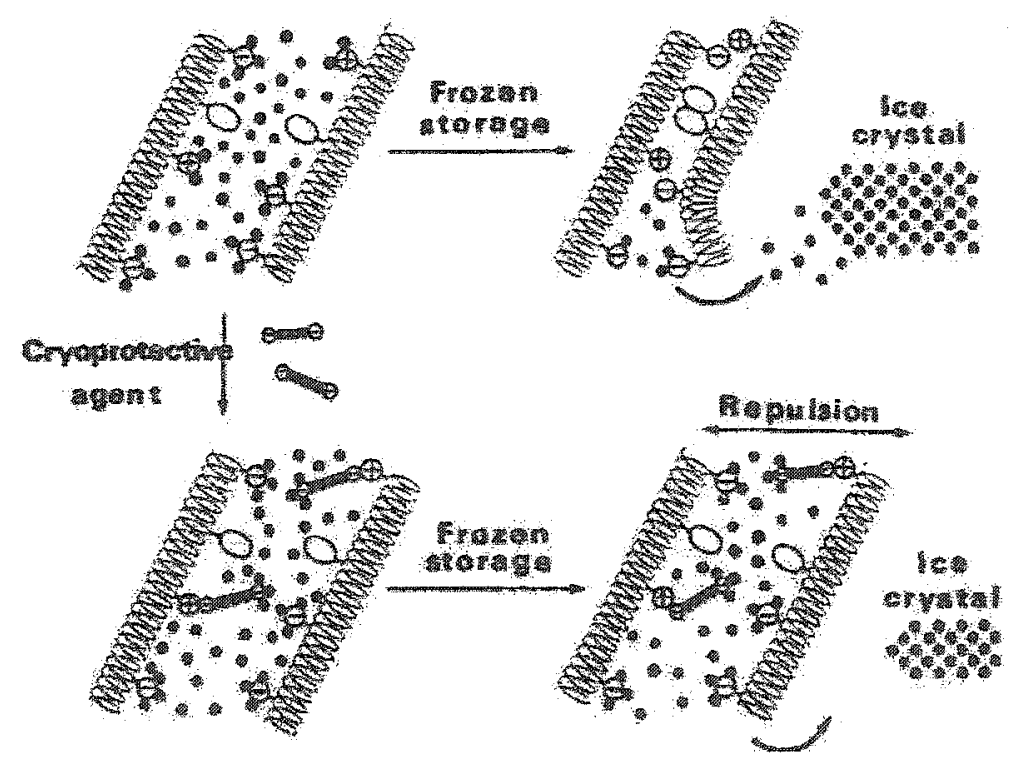

Figure 2.7: A schematic model of denaturation (aggregation) of $\alpha$-helical proteins during frozen storage and its prevention by cryprotectants. $-\oplus$, cationic side chain; - $\ominus$, anionic side chain; $-\odot$, nonpolar side chain; - water molecule; $\Theta-\Theta$, dianionic cryoprotectant molecule (from Matsumoto, 1980). 
For the cryoprotective effects of compounds other than sugars and polyols, a hypothetical mechanism was explained by Matsumoto and Noguchi (1992). In such cases, the cryoprotectant molecules interact and bond with the protein molecules via functional groups on the surface. Water molecules are hydrated onto the other remaining functional groups of the cryoprotectants. Thus, each protein molecule is covered by hydrated cryoprotectant molecules. This way, the frequency of joint contact between protein molecules is lowered, resulting in increased hydration and decreased aggregation of the proteins (Figure 2.7, the lower portion).

In the case of cryoprotectants containing ionic functional groups, particularly those having anionic groups like dicarboxylic acids and dicarboxylic amino acids, the protein molecules become covered by anionic charges. These anionic surface charges result in a repulsive force between the protein molecules and an increased hydration of the protein-cryoprotectant conjugates via other anionic groups on the cryoprotectant molecules,

The higher effectiveness of anionic compounds as cryoprotectants may be explained as follows: At neutral $\mathrm{pH}$, the muscle protein contains a negative net surface charge due to the dominance of exposed anionic residues. Thus, it would require less anionic additive to block the remaining cationic surface groups than cationic additives to block the more dominant anionic surface groups of the protein. Furthermore, the anionic groups tend to become more hydrated than cationic groups. Thus, an ionic coating is more extensively achieved when anionic additives are used. 
A hypothetical mechanism of freeze denaturation in non-helical proteins and its prevention by cryoprotectants was proposed by Matsumoto (1980) (Figure 2.8). When a globular or non-helical protein dissolved in water, the conformation of the native globular molecule is maintained largely by the intramolecular non-polar bonds, which have resulted from a thermodynamic balance between the two systems, $A$ and $B$. System A consists of folded protein-water, while system B consists of unfolded protein-water. In system A, the non-polar groups on the polypeptide backbone are oriented to avoid contact with the water phase (Figure 2.8 top left). In system B some of the non-polar groups are oriented outward into the water phase. The entropy of such oriented water structure is lower as compared with that of the freely mobile water molecules (system A). Thus, in the unfrozen state, system $\mathrm{A}$ is thermodynamically more favored than system B, and common folded structures of protein are found to occur in which intramolecular non-polar bonds exist (Matsumoto and Noguchi, 1992).

If the system is frozen, the water molecules surrounding the protein are displaced to form ice crystals, eliminating the balance between systems A and B. Thus, a new thermodynamic balance must now be considered to exist between system $C$, which consists of folded protein molecule with little or no hydration, and system D, which consists of unfolded proteins with little or no hydration. System D, thermodynamically, is more stable than system $\mathrm{C}$ in the frozen state. During frozen storage the native folded protein molecules undergo conformational changes, resulting in disruption of the active sites for enzyme activity and other biochemical functions of myosin and actin. 


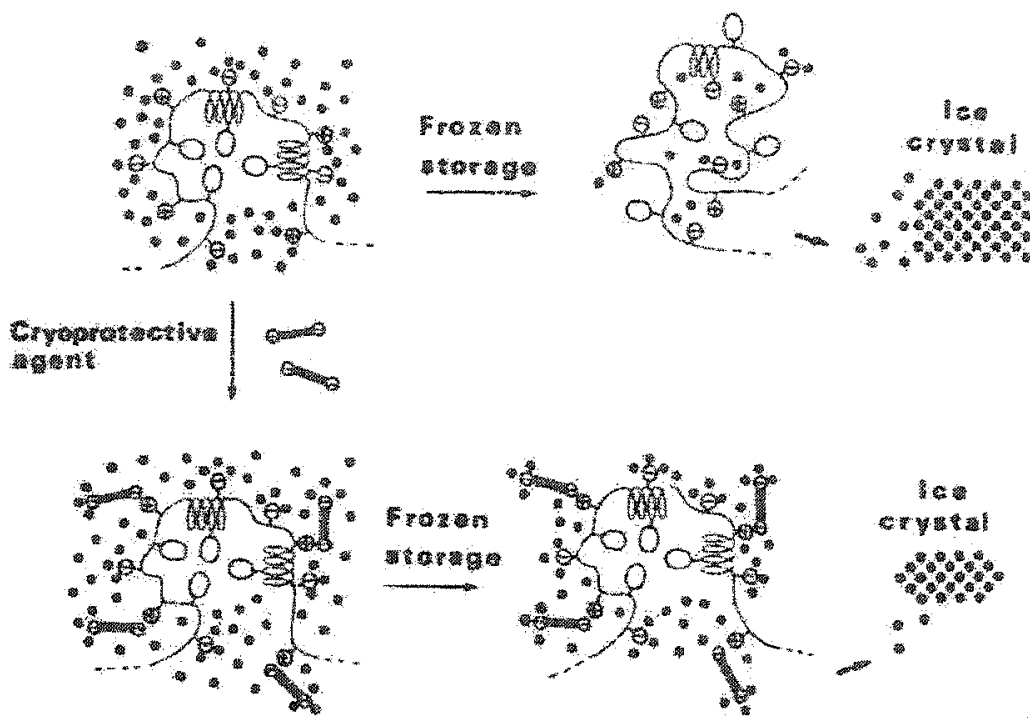

Figure 2.8: A schematic model of denaturation of non-helical (globular) proteins during frozen storage and its prevention by cryoprotectants. .- $\rightarrow$, cationic side chain; $-\ominus$, anionic side chain; - - , nonpolar side chain; - water molecule; $\ominus-\ominus$, dianionic cryoprotectant molecule (from Matsumoto, 1980). 
When cryoprotectants are added prior to freezing, they are dissolved and remain bound to the protein molecules (Figure 2.8 lower left). This results in an increased hydration of the protein molecules, slower growth of ice crystals due to increased resistance to the displacement of water from protein surfaces, and an incomplete freezing of water due to increased amounts of bound water. These reduce the degree of protein unfolding or denaturation (shifts from system A to system D; Figure 2.8 lower right). This may reasonably explain the mechanism of unfolding of non-helical proteins during frozen storage and its prevention by cryoprotectants.

\subsubsection{Other Additives to Improve the Functional Properties}

\subsubsection{Macromolecular Extenders}

Starch is widely used at a level of 5 to $10 \%$ in minced fish products. During heating, starch imbibes some water from the mince and becomes partially gelatinized and fills the pores of the protein network to reinforce it (Pan et al., 1979). At the same time, starch acts as a humectant and improves the freeze-thaw stability of the minced fish products. However, pre-gelatinized starch having no granular structure induces mushy texture with no rigidity increase while addition of potato starch causes the rigidity of fish gel to increase dramatically (Wu et al., 1985). Starch from potato, com, and cassava, and $\alpha$-starch are commonly used. Modified starch with thermal stability is being tested to reduce the degradation of gel strength when minced fish products are thermally processed.

Carbohydrate gums such as alginate, carboxymethylcellulose (CMC), and xanthan gums have been used in the development of surimi products, Carrageenan is 
used in gelling agent blends to improve freeze-thaw stability of surimi products (Lanier, 1986).

Alaska pollock products containing soy protein isolate (SPI) at $2 \%$ in boiled fish gel products and at 3 to $4 \%$ in fried and broiled products showed no difference in gel strength from products containing no SPI extender. Further additions of SPI to the minced Alaska pollock resulted in reduction of gel strength (Motohiro and Numakura, 1978). However, addition of up to $15 \%$ SPI to minced mackerel product still increased the gel strength of the products, probably due to the fact that the gel strength of the minced mackerel was lower than that of the minced Alaska pollock (Pan et al., 1981).

Milk solids, egg white albumin, and gluten are other protein extenders being used in minced fish products. Their effects on textural modification vary with the species and freshness of fish and the type of minced products. Egg white also adds glossiness to the products (Pan, 1990).

\subsubsection{Fats and Oils}

Other ingredients are added to fish mince depending on the type of products. Vegetable oil at 3 to $4 \%$ is often incorporated in molded products (Lee, 1986). Incorporation of plastic fats improves freeze-thaw stability and prevents development of sponge-like texture. It also modifies the cooked gel to become less rubbery and minimizes the textural weakening effect of cooking especially when reaching temperatures between 60 and $70^{\circ} \mathrm{C}$. 


\subsubsection{Protein Additives}

Protein additives are widely used as proteinase inhibitors in surimi processing of Pacific whiting. They improve the physical properties of surimi gels and control the activity of heat-stable proteinase, which breaks down muscle proteins (Morrissey et al., 1993; An et al., 1994). WPC was used at 3\% concentration as a proteinase inhibitor in Pacific whiting surimi. No negative sensory properties have been reported for WPC (Weerasinghe et al., 1996).

Whey protein concentrate (WPC) products are available with protein concentrations from 35 to $80 \%$; whey protein isolate (WPI) are produced with protein contents of $90 \%$ and higher (Giese, 1994). WPC has been utilized mostly as a functional ingredient in foods (Morr, 1992). WPC has many applications in a variety of foods as emulsifier, thickener, whipping agent, flavor enhancer, whitener, foaming agent, water and fat binder, and gelling agent (Hsu and Kolbe, 1996; Morr, 1989). WPC can increase the nutritive value of foods and contribute to the flavor, texture, and color of products (Giese, 1994; Mangino, 1992).

Soybean is still considered to be the world's most inexpensive source of protein. Furthermore, soybean contains a number of minor constituents such as isoflavones, which are believed to have beneficial biological effects in the diet, such as lowering blood cholesterol or prevention of cancer (Anderson and Wolf, 1995).

Isolated soy proteins have found widespread application in formulated food products, and are also used directly as nutritional supplements (Rackis et al., 1975). The application of soybean proteins as ingredients of foods depends on their functional 
properties (Nakamura et al., 1984). The gel forming ability induced on heating of soybean proteins is one of the most important functional properties.

Flaxseed protein products containing different levels of polysaccharide gums have been assessed as additives in food systems such as canned-fish sauce (Dev and Quensel, 1989). Generally, flaxseed protein products were found to have emulsionstabilizing effects. The incorporation of flaxseed protein products at $3 \%$ level produced a smooth and creamy fish sauce without any undesirable flavor and a significant reduction in its red color.

Dev and Quensel $(1986,1988)$ demonstrated that, in general, flaxseed products exhibit favorable water absorption, oil absorption, emulsifying activity, and emulsion stability compared with the corresponding soybean products. It appears that flaxseed proteins are structurally more lipophilic than soybean proteins. Their hydrophilic properties are influenced by the presence of polysaccharide gums in flaxseed protein preparations. The gum in flaxseed has been implicated in enhancing the viscosity and the water binding, emulsifying, and foaming properties of linseed protein products.

Flaxseed protein provides several functional properties that make it a useful food ingredient including solubility, rheological behavior, emulsifying capacity, foaming and whipping ability (Oomah and Mazza, 1995). Dev and Quensel (1986) reported that a flaxseed protein isolate generally exhibited superior functional properties than a commercial soybean isolate. 


\subsection{Techniques to Identify Structural Changes in Proteins}

\subsubsection{Electrophoresis}

Generally, electrophoresis involves the separation of charged ions on the basis of their mobility under the influence of an externally applied electric field and can be used to monitor the changes occurring in food proteins during frozen storage. Gel electrophoresis is an important method for the study of protein structures and is usually used to reveal differences in the characteristics of closely related proteins (Alli \& Baker, 1983).

Sodium dodecyl sulfate polyacrylamide gel electrophoresis (SDS-PAGE) has found wide application and is used to monitor the proteolytic degradation of myofibrils during post-mortem storage of the meat of many different animal species. It is also commonly used to study chemical interactions in gelation of muscle proteins (Hwang et al., 2000; Toyohara et al., 1990; Koohmaraie et al., 1984; Weber and Osborn, 1969).

As solutions of SDS are effective in splitting non-covalent bonds, solubility in this solvent is a useful indicator of the formation of covalent crosslinks. If aggregation on frozen storage involved significant crosslinking, as through -S-S- bond formation or via methylene cross-bridges following reaction of formaldehyde with amino groups, some decrease in solubility in SDS solution might be expected (Mackie, 1993). Urea and SDS can dissociate any non-covalent interactions present in the muscle proteins. The presence of protein polymers in urea and SDS suggests the involvement of only covalent bonds. Briefly, the electrophoretic patterns provide evidence mainly for the formation of hydrogen and hydrophobic bonds on frozen storage. 
Polyacrylamide gel electrophoresis has been largely used as a technique for characterization and identification of species. It has also been used for detection of protein deterioration or adulteration during storage and processing of fish (Cowie, 1968).

SDS-PAGE can be used with great confidence to determine the molecular weights (MW) of polypeptide chains for a wide variety of proteins. By this technique, polypeptide MW may be determined with an accuracy of at least $\pm 10 \%$ (Weber and Osborn, 1969).

Myosin, the main myofibrillar protein in fish, could be easily separated into a single band on SDS-PAGE, and its relative concentration could be roughly estimated by the intensity of the band on the gel (Morrissey et al., 1993).

\subsubsection{Infrared Spectroscopy}

Mid-infrared spectroscopy was assessed as a means for rapidly determining the fat, protein, and moisture content of fish tissues (Darwish et al., 1989). There have been relatively few studies on the structural properties of fish proteins in situ, i.e., in surimi or gel. It has been proposed that Raman spectroscopy can be a useful tool to investigate protein structure in solid and liquid food systems (Li-Chan et al., 1994). This technique has been used to study the sub-structure of myosin (Carew et al., 1975) and the effects of inorganic salts on myosin solutions (Barrett and Peticolas, 1978). Circular dichroism is also another powerful technique for the study of protein structure; however, it is not suitable for direct spectroscopic measurements of samples in solid states (Chen et al., 1974; Compton and Johnson, 1986). The participation of the $\alpha$-helix 
in the setting of fish actomyosin and myosin among different fish species has been studied using circular dichroism measurements (Ogawa et al., 1995). Fluorescence spectroscopy is another tool for studying proteins, but it is incapable of determining peptide backbone structure and is also limited to the study of the environments of tyrosine and tryptophan side chains (Mantulin and Pownall, 1986).

The infrared spectra of proteins exhibit absorption bands associated with their amide groups. There are nine amide bands called amide A, amide B and amides I-VII, in order of decreasing frequency. The most useful infrared band for the analysis of the secondary structure of proteins in aqueous media is the amide I band, which occurs between approximately 1700 and $1600 \mathrm{~cm}^{-1}$. The observed amide I band is usually a complex composite, consisting of a number of overlapping component bands representing helices, $\beta$-structure, turns and random structures. The characteristic frequencies of the secondary structures of proteins are summarized in Table 2.1. Resolution enhancement of the amide I band allows the identification of the various structures present in a protein or peptide. Derivatives and deconvolution can be used to obtain such information (Stuart, 1997).

Attenuated total reflectance (ATR) techniques can be used for samples that are difficult to analyze by normal transmission methods (Sedman et al., 1999). Measurements can be made using an ATR cell in contact. The ATR technique has been used to record the spectra of a wide variety of samples such as minced meat (AlJowder et al., 1997). ATR spectroscopy utilizes the phenomenon of total internal reflection. A beam of radiation entering a crystal will undergo total internal reflection when the angle of incidence at the interface between the sample and the crystal is 
greater than the critical angle, which is a function of the refractive indices of the two surfaces. The crystal used in ATR cells are made from materials which have low solubility in water and are of very high refractive index such as zinc selenide ( $\mathrm{ZnSe}$ ) and germanium (Ge) (Stuart, 1997). FTIR/ATR spectroscopy is a non-invasive, nondestructive method that does not require sample preparation. Using this technique, a reading can be obtained in $2 \mathrm{~min}$ (Gangidi et al., 2003).

Table 2.1: Characteristic amide I band frequencies of protein secondary structures (From Stuart, 1997).

\begin{tabular}{|l|l|}
\hline Frequency $\left(\mathrm{cm}^{-1}\right)$ & Assignment (Structure) \\
\hline $1621-1627$ & $\beta$-Structure \\
\hline $1628-1634$ & $\beta$-Structure \\
\hline $1641-1647$ & Random coil \\
\hline $1651-1657$ & $\alpha-$ Helix \\
\hline $1658-1666$ & Turns and bends \\
\hline $1668-1671$ & Tums and bends \\
\hline $1671-1679$ & $\beta$-Structure \\
\hline $1681-1685$ & Tums and bends \\
\hline $1687-1690$ & Tums and bends \\
\hline $1692-1696$ & Tums and bends \\
\hline
\end{tabular}




\subsubsection{Differential Scanning Calorimetry (DSC)}

DSC is the most widely used of all thermal analysis techniques and is defined as "a technique in which the difference in energy inputs into a substance and a reference material is measured as a function of temperature while the substance and reference material are subjected to a controlled temperature program" ( $\mathrm{Ma}$ et al., 1990).

DSC can be used to detect first-order (melting) transitions such as protein denaturation and second-order (glass transition) transitions including frozen products. The changes induced in food proteins by thermal treatments often lead to denaturation or unfolding of the native structure. Since the disruption of intramolecular hydrogen bonds is an endothermic reaction, thermal denaturation can be detected as an endothermic peak in the DSC thermogram. On the other hand, aggregation and the break up of hydrophobic interactions are exothermic reactions (Ma et al., 1990).

The overall enthalpy $(\Delta \mathrm{H})$ value can be calculated from the area under the transition. It provides an estimate of the thermal energy required to denature the protein. The temperature of denaturation $\left(T_{d}\right)$ can be estimated from the transition, generally as the peak temperature ( $\left.\mathrm{T}_{\mathrm{p}}\right)$ (Ma et al., 1990).

DSC determines the temperature and heat flow associated with material transitions as a function of time and temperature. It also provides quantitative and qualitative data on endothermic and exothermic processes of materials during physical transitions that are caused by phase changes, melting, oxidation, and other heat-related changes. This information helps the scientist or engineer identify processing and enduse performance. 
DSC has been reported to be a very useful technique for monitoring changes in fish muscle proteins during frozen storage (Herrera et al., 2001; Howell et al., 1991; Poulter et al., 1985). DSC enables fish muscle proteins to be studied in situ. Some authors have pointed out that it allows differences between cryoprotectants to be observed (Sych et al., 1990; Park and Lanier, 1987). 


\section{Chapter 3}

\section{CHANGES IN PROTEIN STRUCTURE DURING PREPARATION AND FROZEN STORAGE OF ALASKA POLLOCIK SURIMI}

\subsection{INTRODUCTION}

In the first part of this research, the structural changes in proteins that are associated with the preparation and frozen storage of surimi were investigated. Since the washing procedure for preparation of surimi is of great importance with regard to the quality of the final product, a method for the preparation of surimi from Alaska pollock was optimized, and the effects of rinsing conditions such as number of washing cycles on the quality of surimi were studied. The laboratory-prepared surimi was either slowly frozen or subjected to rapid freezing using liquid air; in either case surimi was subjected to frozen storage at $-20^{\circ} \mathrm{C}$ for a period of 24 months since it was reported that lean fish species have the longest recommended storage time of 8 to 24 months within the range of fish species used for human consumption (Mackie, 1993). Protein structural changes were monitored using electrophoresis, FTIR/ATR spectroscopy, and DSC techniques during frozen storage. Furthermore, a comparative study of rapid and slow freezing regarding the stability of protein structure was made. 


\subsection{MATERIALS AND METHODS}

\subsubsection{Preliminary Experiments}

\subsubsection{Preparation of Surimi}

The purpose of these preliminary experiments was to establish methods for surimi preparation and separation of fish protein fractions.

Fresh Atlantic sole fillets were purchased from a local supermarket (Provigo, Baie-D'Urfe, QC). The fish were kept on ice in an insulated box and used for surimi preparation immediately. A quantity (317.7 g) of fish was chopped and blended (Osterizer blender) to obtain minced fish. The minced fish was used to prepare surimi as follows: Water was added to the minced fish at a ratio of (i) 3:1 water:minced fish (W/M) and (ii) 5:1 water:minced fish. Each water/fish mixture was stirred for 10 minutes. This washing process was repeated 3 times. The water was removed by a stainless steel press and cheesecloth after each washing cycle. The product with 5:1 W/M was divided into two portions before the last washing cycle. For one part, $0.2 \%$ $(\mathrm{w} / \mathrm{v}) \mathrm{NaCl}$ was added to the wash water. Samples from the product of each cycle (surimi) and from the wash waters were taken and kept at $-20^{\circ} \mathrm{C}$.

Market raw surimi (H. Aida Inc., Valleyfield, QC) was also obtained for comparison purposes. 


\subsubsection{Separation of Fish Protein Fractions (Myofibrillar, Sarcoplasmic and Stroma)}

The method of Dyer et al. (1950) as modified by Machado and Sgarbiere (1991) was used to separate the fish protein fractions from the Atlantic sole fillet samples. The extraction was carried out at approximately $4^{\circ} \mathrm{C}$. A sample $(20 \mathrm{~g})$ was blended at high speed (Oster blender) in $166.5 \mathrm{ml}$ buffer solution ( $5 \% \mathrm{NaCl}$ in $0.02 \mathrm{M}$ $\mathrm{NaHCO}_{3}, \mathrm{pH}$ 7.4) for 2 min. The mixture was centrifuged (4000 RPM or $2831 \mathrm{x} \mathrm{g}, 30$ min, $4^{\circ} \mathrm{C}$ ). The supernatant containing the sarcoplasmic and myofibrillar protein fractions was retained. The pellet, containing mainly stroma, collagen and denatured proteins, was lyophilized. The myofibrillar fraction was precipitated from the supernatant by 10 -fold dilution with cold distilled water and holding the mixture at $4{ }^{\circ} \mathrm{C}$ for $24 \mathrm{~h}$. The diluted salt extract was centrifuged (7500 RPM or $9954 \mathrm{x} \mathrm{g}, 15 \mathrm{~min}$, $4^{\circ} \mathrm{C}$ ). The supernatant, consisting of sarcoplasmic protein, was lyophilized and kept for further analysis. The precipitate, containing myofibrillar proteins, was resuspended in 15 volumes of $1.1 \mathrm{M} \mathrm{KI}$ in $0.1 \mathrm{M}$ potassium phosphate buffer $(\mathrm{pH} 7.4)$. The mixture was blended for $30 \mathrm{~s}$ at high speed then centrifuged (4000 RPM, $15 \mathrm{~min}, 4^{\circ} \mathrm{C}$ ). The supernatant containing myofibrillar protein was lyophilized. 


\subsubsection{Surimi Preparation from Alaska pollock}

The procedure discussed in section 3.1.1.1 was used to prepare surimi from Alaska pollock (Theragra chalcogramma), based on the method of Lee (1984) with some modifications. Frozen minced Alaska pollock was obtained from Blue Water Seafoods (Lachine, QC). A quantity of frozen minced fish was thawed overnight at $4^{\circ} \mathrm{C}$ and washed $(15 \mathrm{~min})$ with chilled water $\left(2-4^{\circ} \mathrm{C}, \mathrm{pH} 7.2\right)$. The ratio of water to minced fish was 3:1 (v/w). The wash water was separated using a stainless steel press and cheesecloth. The washing procedure was repeated 5 times; after each washing cycle samples of surimi were (a) directly stored at $-20^{\circ} \mathrm{C}$ (slow freezing), and (b) frozen by immersion in liquid air (LA) before storage at $-20^{\circ} \mathrm{C}$ (rapid freezing). Figure 3.1 shows a schematic diagram of the surimi preparation procedure.

\subsubsection{Protein Determination}

The protein content of wash waters was determined using the method of Hartree (1972), Bovine serum albumin (Sigma Chemicals Co., St. Louis, MO) was used as a standard. The nitrogen content of minced fish and surimi was determined using the AOAC (1984) Kjeldahl procedure. The \% nitrogen was converted to \% protein using a factor of 6.25 . 
Frozen Minced Fish (171.2 g)

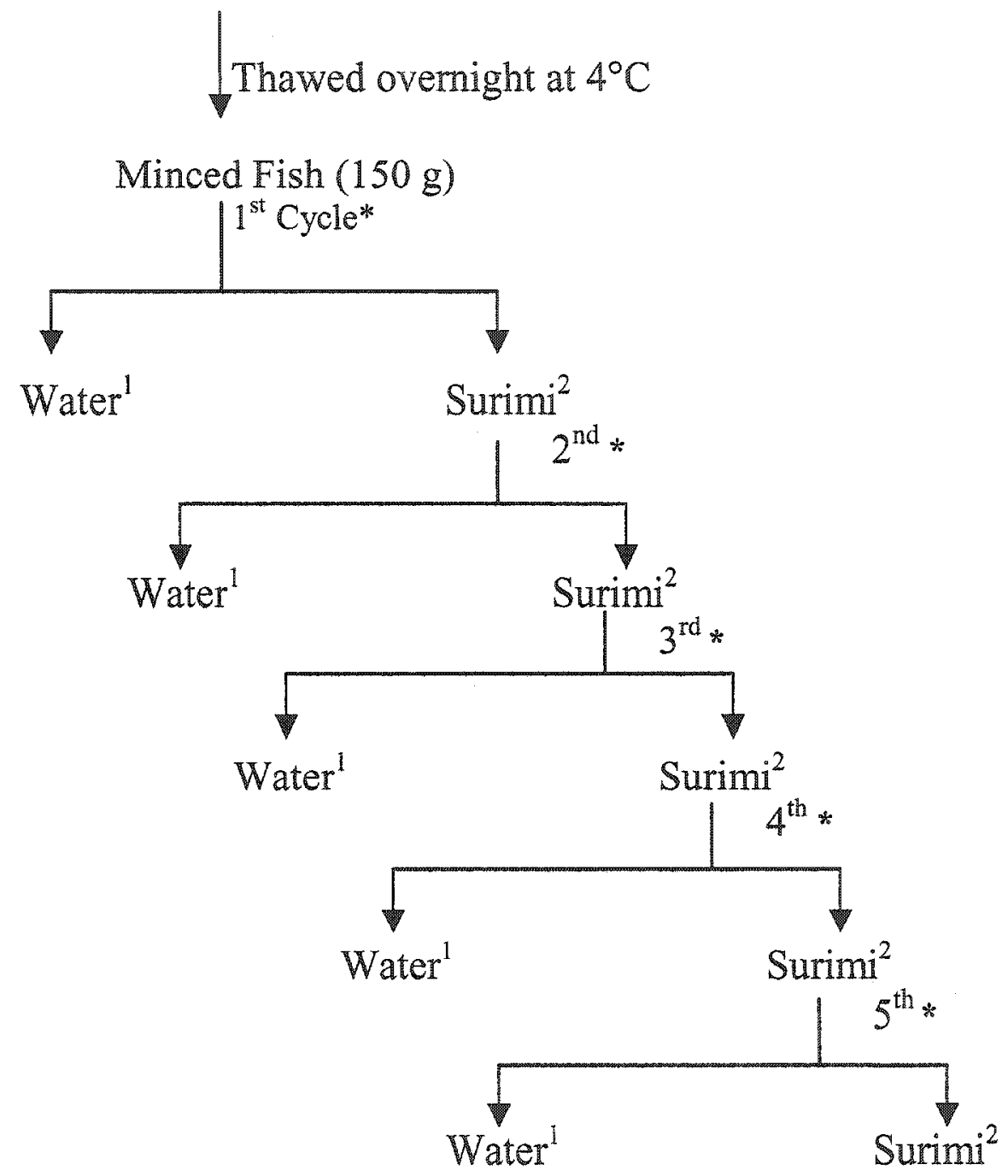

* Water/minced fish ratio, $3: 1$

$75 \mathrm{ml}$ of wash water was taken for further analyses using the Hartree method and SDSPAGE.

210 and $5 \mathrm{~g}$ of surimi from each cycle and minced fish were taken for slow and rapid freezing (by liquid air), respectively, and stored at $-20^{\circ} \mathrm{C}$.

Figure 3.1: Procedure used for preparing surimi from Alaska pollock. 


\subsubsection{Electrophoretic Analyses}

Slab-gel electrophoresis using homogeneous and gradient polyacrylamide gels under denaturing and reducing conditions were performed as described by Laemmli (1970). Non-denaturing homogeneous and gradient polyacrylamide gels were prepared based on the method of Davis (1964). All electrophoresis experiments were carried out on a Mini-Protean II Electrophoresis cell unit connected to an electrophoresis power supply (BioRad, Hercules, CA). All chemicals were purchased from BioRad (Mississauga, Ontario, Canada) and Sigma (St. Louis, MO).

\subsubsection{Sodium Dodecyl Sulfate Polyacrylamide Gel Electrophoresis (SDS-PAGE)}

\subsection{Sample Preparation}

The samples for SDS-PAGE were prepared from $2 \mathrm{mg}$ lyophilized minced fish and surimi in $1 \mathrm{ml}$ sample buffer. For wash waters, $200 \mu$ of liquid samples in $1 \mathrm{ml}$ sample buffer were used. The sample buffer consisted of Tris- $\mathrm{HCl}(0.5 \mathrm{M}, \mathrm{pH} 6.8)$, glycerol, SDS (10\%), 2-mercaptoethanol, bromophenol blue (0.1\%) and distilled water. The sample mixtures were heated $\left(95^{\circ} \mathrm{C}, 5 \mathrm{~min}\right)$ and cooled to room temperature before loading on the gel. The following SDS-PAGE broad range molecular weight standard mixture (Biorad, Hercules, CA) was subjected to the same procedure as described above: myosin (200 kDa), $\beta$-galactosidase (116.5 kDa), phosphorylase $\mathrm{B}(97.4 \mathrm{kDa})$, serum albumin $(66.2 \mathrm{kDa})$, ovalbumin $(45 \mathrm{kDa})$, carbonic anhydrase $(31 \mathrm{kDa})$, trypsin inhibitor (21.5 kDa), lysozyme (14.4 kDa), and aprotinin (6.5 kDa). 


\subsection{Gel Concentration and Preparation}

The separation gel and stacking gel were $12 \%$ and $4 \%$ acrylamide, respectively, for SDS-PAGE. Separation gel was prepared using the following reagents: acrylamide, Tris-HCl (1M, pH 8.8), glycerol, SDS (10\%), distilled water, ammonium persulfate (APS, 10\%) agent, and tetramethylethylene-diamine (TEMED). The mixture was poured between $7 \times 8 \mathrm{~cm}$ glass plates and allowed to polymerize (30 to $45 \mathrm{~min}$ ). After polymerization the area above the separation gel was dried with filter paper. Stacking gel was prepared with acrylamide, Tris- $\mathrm{HCl}(0.5 \mathrm{M}, \mathrm{pH} 6.8)$, SDS (10\%), distilled water, APS (10\%), and TEMED. The mixture was poured over the separation gel using a comb to make wells for sample loading and allowed to polymerize about $30 \mathrm{~min}$. After polymerization the wells were dried and cleaned using filter papers. Soluble proteins $(15 \mu l)$ and molecular weight markers $(5 \mu l)$ were loaded into the wells.

\subsection{Electrophoresis Running Conditions}

The running buffer consisted of a tris-glycine buffer ( $\mathrm{pH}$ 8.3) containing SDS $(1 \%)$. Electrophoresis was carried out at a constant current of $15 \mathrm{~mA} / g e l$, voltage of $400 \mathrm{~V}$ at $15 \mathrm{~W}$. Running times varied usually between 1 to $1.5 \mathrm{~h}$, when the tracking dye reached the bottom of the gel.

The conditions discussed above were used for electrophoresis with the pre-cast gradient gels (BioRad, Hercules, CA). 


\subsection{Protein Fixing, Staining and Destaining}

Gels were removed from the glass plates and immersed in a fixing solution consisting of $20 \%(\mathrm{~V} / \mathrm{V})$ methanol and $10 \%(\mathrm{~V} / \mathrm{V})$ acetic acid in water for 1 to $2 \mathrm{~h}$, stained with Coomassie Brilliant Blue R-250 (0.1\% W/V) in 20\% (V/V) methanol and $10 \%(\mathrm{~V} / \mathrm{V})$ acetic acid in water overnight, then destained with the same fixing solution by repeated washing until the background color was removed. The destained gels were stored in $7 \%(\mathrm{~V} / \mathrm{V})$ acetic acid in a refrigerator until they were photographed.

\subsubsection{Native-PAGE}

\subsection{Sample Preparation}

The samples for native-PAGE were prepared from $10 \mathrm{mg}$ of lyophilized samples of minced fish and surimi dissolved in $0.5 \mathrm{ml}$ sample buffer containing Tris$\mathrm{HCl}(1.5 \mathrm{M}, \mathrm{pH} 8.8)$, glycerol, bromophenol blue (0.1\%), and distilled water. The following high molecular weight (HMW) calibration kit for native electrophoresis (Amersham Pharmacia Biotech, Kirkland, QC) was used to estimate the molecular weight (MW) of bands separated on pre-cast 4-20\% gradient gels: thyroglobulin (669 $\mathrm{kDa}$ ), ferritin (440 kDa), catalase (232 kDa), lactate dehydrogenase (140 kDa), and bovine serum albumin ( $66 \mathrm{kDa}$ ). Pure ovalbumin with $\mathrm{MW}$ of $43 \mathrm{kDa}$ was added to extend the range of HMW standard. Precision prestained standard (BioRad, Hercules, CA) was also used as a low molecular weight (LMW) standard (10-250 kDa). 


\subsection{Gel Concentration and Preparation}

Homogeneous separation gels (10\%) with stacking gels (4\%) and pre-cast 4-20\% gradient gel (BioRad, Hercules, CA) were used for native-PAGE. Soluble protein $(30 \mu \mathrm{l})$ and molecular weight markers $(10 \mu \mathrm{l})$ were loaded into the sample wells. Gel preparation and sample application were similar to that described in section 3.1.4.1.2.

\subsection{Electrophoresis Running Conditions}

The running buffer consisted of Tris-glycine buffer $(\mathrm{pH}$ 8.3). Electrophoresis was performed at a constant current of $7.5 \mathrm{~mA} /$ gel with voltage and power limits set at $400 \mathrm{~V}$ and $15 \mathrm{~W}$, respectively. Running time varied between 3 to $4 \mathrm{~h}$, when the bromophenol blue tracking dye reached the bottom of the gel.

\subsection{Protein Fixing, Staining and Destaining}

The procedure is the same as that described in the section 3.1.4.1.4 for protein fixing, staining, and destaining.

\subsubsection{Fourier Transform Infrared/Attenuated Total Reflectance (FTIR/ATR) Spectroscopy}

An FTIR spectrometer (Excalibur, BioRad, Cambridge, MA) purged with dry air from a Balston dryer (Balston, Lexington, MA) and equipped with a ZnSe singlebounce ATR accessory (SB-ATR) (PIKE, Madison, WI) was employed to record the FTIR spectra. A small amount of freeze-dried powder was placed on the ATR crystal 
( $5 \mathrm{~mm}$ in diameter). After addition of a drop of $\mathrm{D}_{2} \mathrm{O}$, the sample was pressed gently against the crystal. Preliminary experiments were performed without addition of $\mathrm{D}_{2} \mathrm{O}$. FTIR spectra were recorded in triplicate to ensure spectral reproducibility and to confirm sample homogeneity. A total of 64 scans were co-added at $4 \mathrm{~cm}^{-1}$ resolution and ratioed against a background spectrum recorded from the bare crystal. The spectra were then deconvolved using Omnic 6 software (Nicolet, Madison, WI) with a $\mathrm{k}$ factor of 2.3 and a bandwidth of $30 \mathrm{~cm}^{-1}$.

\subsubsection{Differential Scanning Calorimetry (DSC)}

Freeze-dried samples were subjected to thermal analysis using a DSC Q100-T Zero Technology with Auto-sampler, equipped with DSC Refrigerated Cooling System (TA Instruments INC, New Castle, DE), and monitored by the Universal Analysis 2000 software (ver. 3.7A) for Windows ${ }^{\circledR}$. Nitrogen (PRAXair, Montreal, QC) was used as purge gas $\left(50 \mathrm{ml} \mathrm{min}^{-1}\right)$ for all scans. Heat flow and melting point were calibrated from the melting endotherm of indium. The heating rate used for calibration was the same as that used for scanning samples to be analyzed. An empty pan was always used as a reference to obtain a baseline.

Samples ( 2 to $3 \mathrm{mg}$ ) were weighed into aluminum pans $(25 \mu)$, and $0.1 \mathrm{M}$ phosphate buffer (pH 7.4) was added to bring the total weight to $13-15 \mathrm{mg}$. The pans were hermetically sealed, placed on the calorimetric cell, allowed to equilibrate at $25^{\circ} \mathrm{C}$, then heated to $100^{\circ} \mathrm{C}$ at the rates of $10^{\circ} \mathrm{C}$ and $5^{\circ} \mathrm{C} \mathrm{min}{ }^{-1}$. Each thermal transition was defined in terms of the maximum denaturation temperature $\left(T_{\max }\right)$, which is the temperature corresponding to the highest amount of heat applied, and the enthalpy of 
denaturation $\left(\Delta H_{\mathrm{d}}, \mathrm{Jg}^{-1}\right)$, the area that results from integrating the peak for each transition.

All of the experiments described in this section were repeated at least twice until good reproducibility was obtained; the results are the mean of duplicates.

\subsection{RESULTS AND DISCUSSION}

\subsubsection{Preliminary Experiments}

The objectives of these preliminary experiments were to establish an optimized method for surimi preparation (such as the water:minced fish ratio, and addition of salt), to obtain the electrophoretic patterns for fish protein fractions, and to measure the protein contents of each wash water.

Figure 3.2 shows the SDS-PAGE patterns of minced fish, the separated fish protein fractions, market raw surimi, surimi made in the laboratory with and without the addition of salt to the third wash water, and the $3^{\text {rd }}$ wash water. Table 3.1 presents the molecular weights of the main bands (A to I in Figure 3.2) and the tentative identity of the proteins.

These results show that the surimi prepared in the laboratory has a similar electrophoretic pattem as that from market raw surimi. From Figure 3.2 (lanes 6 and 9), it is also observed that an increase of the water to minced fish ratio (W/M from $3: 1$ to 5:1) does not have an apparent effect on the electrophoretic pattems of the produced surimi. The higher volume of water did not affect the quality of surimi; however it made the process harder to handle with much more waste water. 

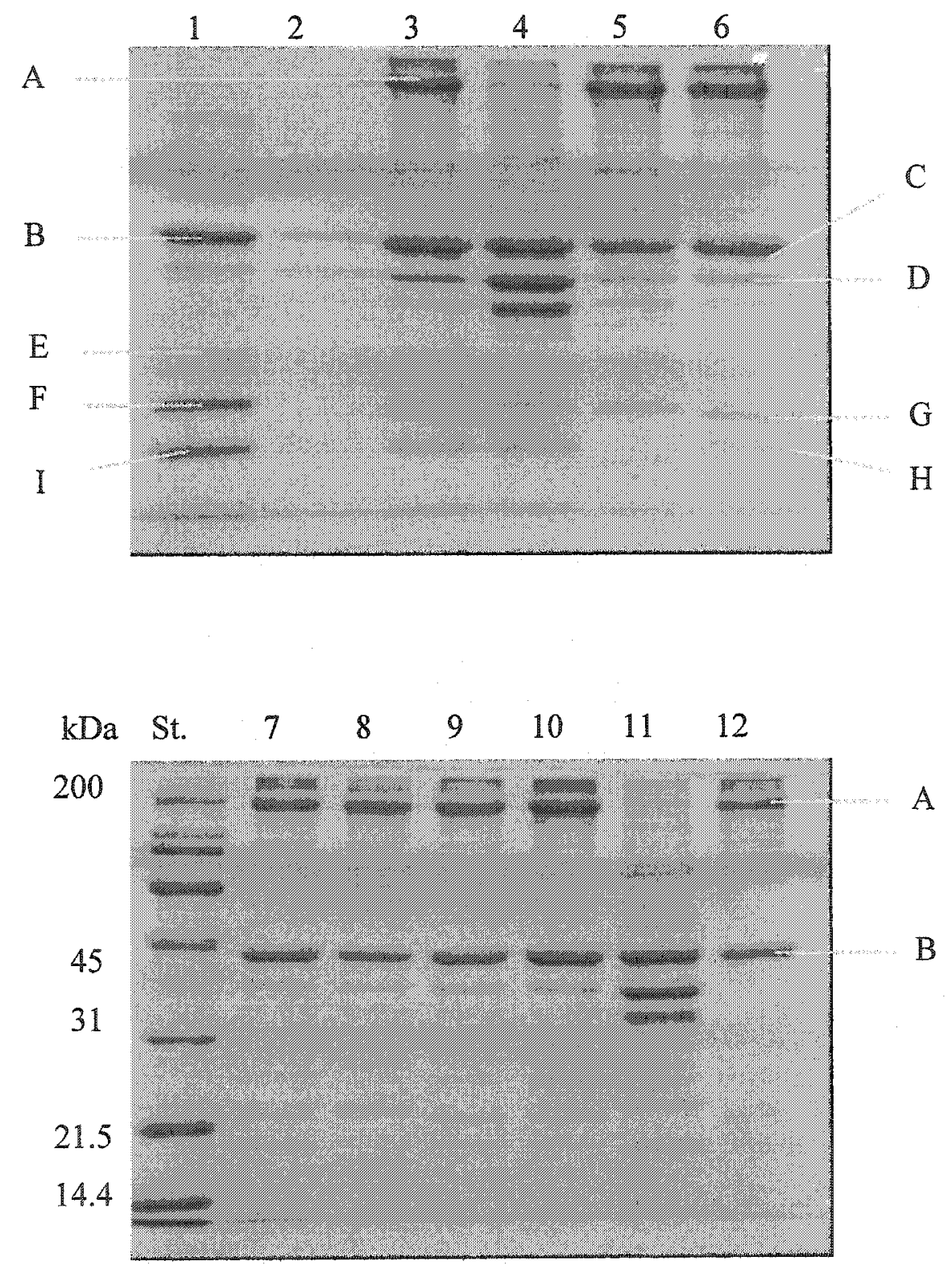

Figure 3.2: SDS-PAGE patterns of minced fish, surimi, wash water, and protein fractions of fish; 1 third wash water, 2 sarcoplasmic proteins, 3 and 7 minced fish, 4 and 11 myofibrillar proteins, 5 and 8 market surimi, 6 surimi ( $3: 1 \mathrm{~W} / \mathrm{M}), 9$ surimi $(5: 1 \mathrm{~W} / \mathrm{M}), 10$ surimi with added salt $(5: 1 \mathrm{~W} / \mathrm{M}), 12$ collagen, $\mathrm{St}$. broad range standard. 
Table 3.1: Molecular weight and presumptive identification of bands present in SDSPAGE patterns of minced fish, surimi, wash water and fish protein fractions.

\begin{tabular}{|c|c|c|c|c|c|c|c|c|c|}
\hline Band & $\begin{array}{c}\text { Calculated } \\
\text { MW (kDa) }\end{array}$ & $\begin{array}{c}\text { Presumptive } \\
\text { Identity* }\end{array}$ & $\begin{array}{c}\text { Minced } \\
\text { Fish }\end{array}$ & $\begin{array}{c}\text { Market } \\
\text { Surimi }\end{array}$ & $\begin{array}{c}\text { Lab- } \\
\text { Made } \\
\text { Surimi }\end{array}$ & Myofibrillar & Sarcoplasmic & Collagen & $\begin{array}{c}\text { Wash } \\
\text { Water }\end{array}$ \\
\hline $\mathrm{A}$ & 196.3 & MHC† & $\mathrm{X}$ & $\mathrm{X}$ & $\mathrm{X}$ & - & - & $\mathrm{X}$ & - \\
\hline $\mathrm{B}$ & 45.4 & Actin & $\mathrm{X}$ & $\mathrm{X}$ & $\mathrm{X}$ & $\mathrm{X}$ & $\mathrm{X}$ & $\mathrm{X}$ & $\mathrm{X}$ \\
\hline $\mathrm{C}$ & 43.2 & $\begin{array}{c}\text { Creatin } \\
\text { kinase }\end{array}$ & $\mathrm{X}$ & $\mathrm{x}$ & $\mathrm{x}$ & $\mathrm{x}$ & $\mathrm{x}$ & $\mathrm{X}$ & $\mathrm{x}$ \\
\hline $\mathrm{D}$ & 38.8 & Aldolase & $\mathrm{X}$ & $\mathrm{X}$ & $\mathrm{X}$ & $\mathrm{X}$ & $\mathrm{X}$ & $\mathrm{X}$ & $\mathrm{X}$ \\
\hline $\mathrm{E}$ & 34.5 & Tropomyosin & $\mathrm{x}$ & $\mathrm{x}$ & $\mathrm{x}$ & $\mathrm{X}$ & - & - & - \\
\hline $\mathrm{F}$ & 22.8 & Troponin-I & $\mathrm{X}$ & $\mathrm{X}$ & - & $\mathrm{X}$ & - & - & $\mathrm{X}$ \\
\hline $\mathrm{G}$ & 21.8 & Troponin-C & $\mathrm{X}$ & - & $\mathrm{X}$ & - & - & $\mathrm{X}$ & - \\
\hline $\mathrm{I}$ & 19.1 & MLC & $\mathrm{X}$ & - & $\mathrm{X}$ & - & - & - & - \\
\hline
\end{tabular}

X Major band

$x$ Minor band

- Not present in gel

+ Myosin heavy chain

$\mp$ Myosin light chains

* According to Xiong (1997) and Haard (1995) 
Salt (up to $0.2 \%$ ) is usually added to the last wash to remove water but should not be at a level to solubilize the actin and myosin. Our results (Figure 3.2, lanes 9 and 10) indicate that the addition of salt to the last wash water did not affect the electrophoretic pattems of the surimi. Thus, surimi for the subsequent experiments was prepared using the W/M ratio of 3:1 without the addition of salt to the last wash water, in order to reduce the waste water, and to avoid any possible interference of salt on further experimental analyses.

The residue after extraction of sarcoplasmic and myofibrillar proteins, called stroma, is composed of the main connective tissue proteins - collagen and elastin, of reticulin, and of denatured aggregated myofibrillar and possibly sarcoplasmic proteins, which lost their characteristic solubility (Sikorski et al., 1990b). This may explain why some common bands were observed in the SDS-PAGE separation profiles of myofibrillar, sarcoplasmic and collagen fractions of fish protein (Figure 3.2).

Protein contents of lyophilized samples of wash waters ( $1 \mathrm{mg}$ ), determined by the Hartree method (1972), were $0.11,0.19$, and $0.28 \mathrm{mg} / \mathrm{ml}$ for the $1^{\text {st }}, 2^{\text {nd }}$ and $3^{\text {rd }}$ wash waters, respectively. The increase of protein content with the increase of washing cycles is attributed to the use of lyophilized samples of wash waters. 


\subsubsection{Surimi Preparation from Alaska Pollock}

Since myofibrillar proteins of various animal species are most stable at neutral pH (Matsumoto and Noguchi, 1992), neutral distilled water was used for rinsing minced fish. It has been reported that when either basic or acidic rinsing solution was employed, salt-soluble protein in surimi decreased and freezing denaturation of surimi protein increased (Wang et al., 2001).

Table 3.2 shows some parameters measured during surimi preparation from Alaska pollock. A total of $2.22 \mathrm{~g}$ protein was removed from minced fish during the five washing cycles. The amount of water-soluble protein in minced fish decreased progressively with each washing cycle. The yield of surimi from minced fish was $60.2 \%$ (a quantity of $90.4 \mathrm{~g}$ surimi was obtained at the end of the $5^{\text {th }}$ washing cycle from $150 \mathrm{~g}$ of minced fish at the start of the $1^{\text {st }}$ washing cycle, Table 3.2). With our surimi preparation process, a quantity of $\sim 14.5 \mathrm{~kg}$ of waste water would be generated to produce $1 \mathrm{~kg}$ of surimi, while Lin and Park (1995) reported that for a shore-side operation $29.1 \mathrm{~kg}$ waste water was generated for the production of $1 \mathrm{~kg}$ of surimi. Table 3.2 shows that the protein content of wastewater was between 0.36 and 3.62 $\mathrm{mg} / \mathrm{ml}$. It has been estimated that $50 \%$ of total proteins are lost during washing (Park et al., 1997). Therefore, excessive washing not only increases the cost for water usage and wastewater disposal, but also results in a yield loss.

The protein contents of minced fish and surimi, measured using the Kjeldahl method, were $19.5 \%$ and $21.59 \%$, respectively. 
Table 3.2: Parameters measured during surimi preparation.

\begin{tabular}{|c|c|c|c|c|c|}
\hline & $1^{\text {st }}$ cycle & $2^{\text {nd }}$ cycle & $3^{\text {rd }}$ cycle & $4^{\text {th }}$ cycle & $5^{\text {th }}$ cycle \\
\hline $\begin{array}{c}\text { Weight of fish or } \\
\text { surimi }(\mathrm{g})\end{array}$ & 150 & 81 & 78.4 & 78 & 85.4 \\
\hline $\begin{array}{c}\text { Volume of water } \\
\text { added (m) }\end{array}$ & 450 & 243 & 235.2 & 234 & 256.2 \\
\hline $\begin{array}{c}\text { Weight of final suimi } \\
(\mathrm{g})\end{array}$ & 96.6 & 93.7 & 93.7 & 100.7 & 90.4 \\
\hline $\begin{array}{c}\text { Volume of wash } \\
\text { water at the end of } \\
\text { each cycle (m1) }\end{array}$ & 470 & 210 & 198 & 193 & 235.5 \\
\hline $\begin{array}{c}\text { Protein content } \\
\text { mg/ml }\end{array}$ & 3.62 & 1.061 & 0.58 & 0.50 & 0.36 \\
\hline $\begin{array}{c}\text { Protein removed } \\
\text { (mg) }\end{array}$ & 1701 & 222.8 & 114.8 & 96.5 & 84.7 \\
\hline $\begin{array}{c}\text { \% Of total protein } \\
\text { removed }\end{array}$ & 57.7 & 7.46 & 3.73 & 3.25 & 2.85 \\
\hline
\end{tabular}

${ }^{1}$ Total protein removed after five washing cycles $=2.22 \mathrm{~g}$

\subsubsection{Properties of Wash Waters}

\subsubsection{Electrophoretic Analysis}

The SDS-PAGE separation profiles of lyophilized and liquid samples of wash waters are shown in Figure 3.3. The intensity of bands from the first to the fifth cycle decreased for the liquid samples of wash waters, indicating the removal of watersoluble proteins in the initial steps of washing. However, an increase of band intensity was observed for the lyophilized samples possibly due to the increase in purity of remaining compounds after successive washing cycles. Myofibrillar proteins, particularly actin, are also removed during the washing cycles. 


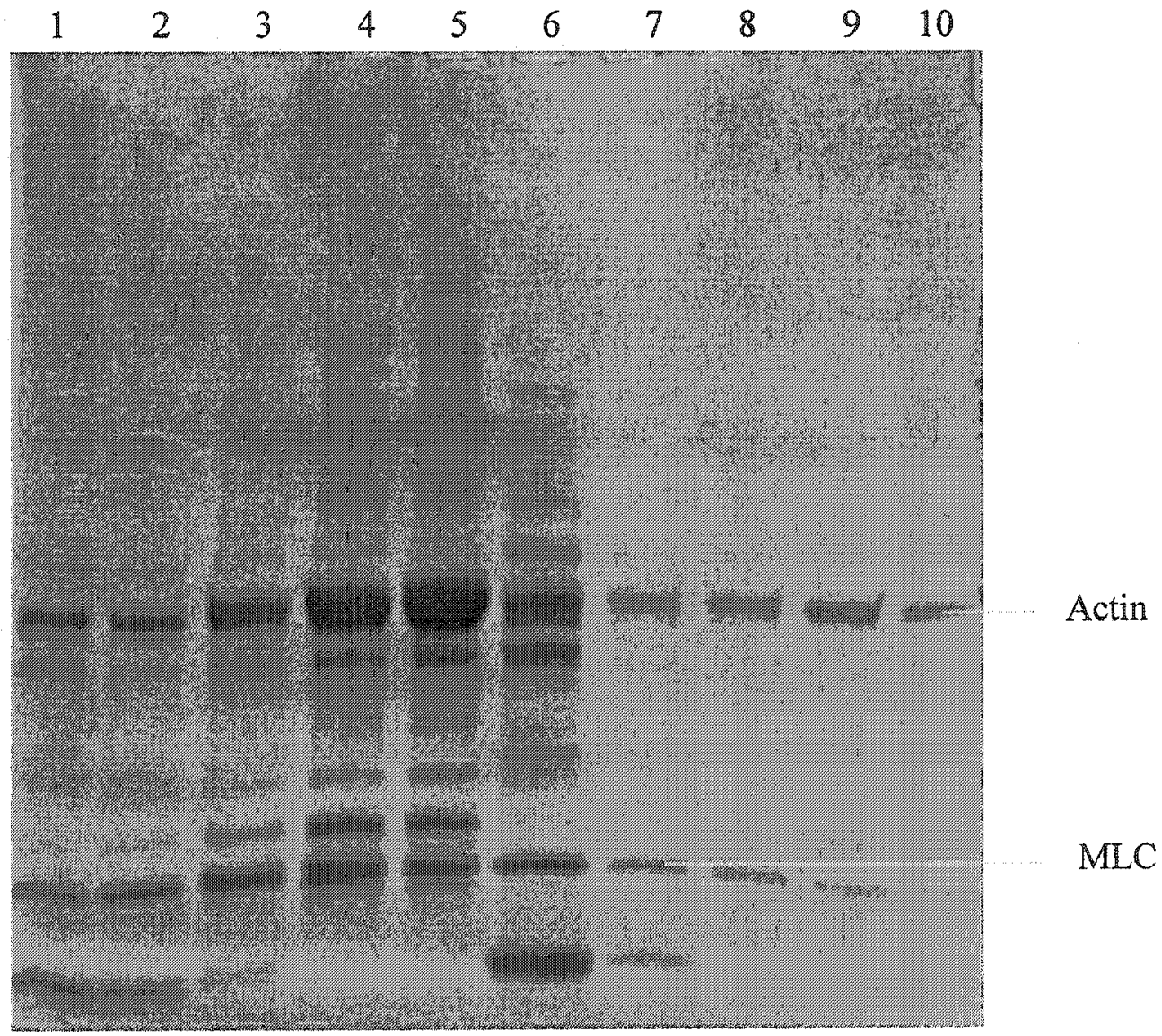

Figure 3.3: SDS-PAGE patterns of wash waters; 1 -5 first to fith washing cycle, lyophilized samples; 6-10 first to fifth washing cycles, liquid samples. 


\subsubsection{FTIR/ATR Analysis}

The baseline-corrected and Fourier self deconvolved (FSD) FTIR/ATR spectra of wash waters are shown in Figures 3.4 and 3.5, respectively. The first to the third wash waters (spectra $a, b$, and c) exhibited similar spectra; however, in the $1^{\text {st }}$ washing cycle, possibly some free fatty acids $\left(1711 \mathrm{~cm}^{-1}\right)$, triglycerides $\left(1740 \mathrm{~cm}^{-1}\right)$, and phospholipids were also removed in addition to proteins. Phospholipids are often preferentially hydrolyzed during frozen storage of fish, and as they are the main lipid component of the flesh of non-fatty species, it is very likely that malonaldehyde and other products of oxidation will be produced even under conditions recommended for storage (Mackie, 1993).

The spectra of the $4^{\text {th }}$ and the $5^{\text {th }}$ wash waters (spectra $d$ and e) were very similar to each other, and different from those of the first three wash waters. This indicates the removal of mainly proteins in the $4^{\text {th }}$ and $5^{\text {th }}$ washing cycles that are different from those in the first three washing cycles. In the $4^{\text {th }}$ and the $5^{\text {th }}$ washing cycles, proteins with ionized carboxyl groups and protonated amine groups were washed out; moreover, their spectra were similar to surimi (shown later in Figure 3.10) indicating the loss of myofibrillar proteins in these wash cycles. The results suggest that three washing cycles are adequate to prepare surimi.

It should be noted that the position of the amide II band shifts from $1550 \mathrm{~cm}^{-1}$ to a frequency of $1450 \mathrm{~cm}^{-1}$ when deuterated. The amide II band of the deuterated protein overlaps with the $\mathrm{H}-\mathrm{O}-\mathrm{D}$ bending vibration, however, the remainder of the amide II band at $1550 \mathrm{~cm}^{-1}$ may provide information about the accessibility of solvent to the peptide backbone (Stuart, 1997). 


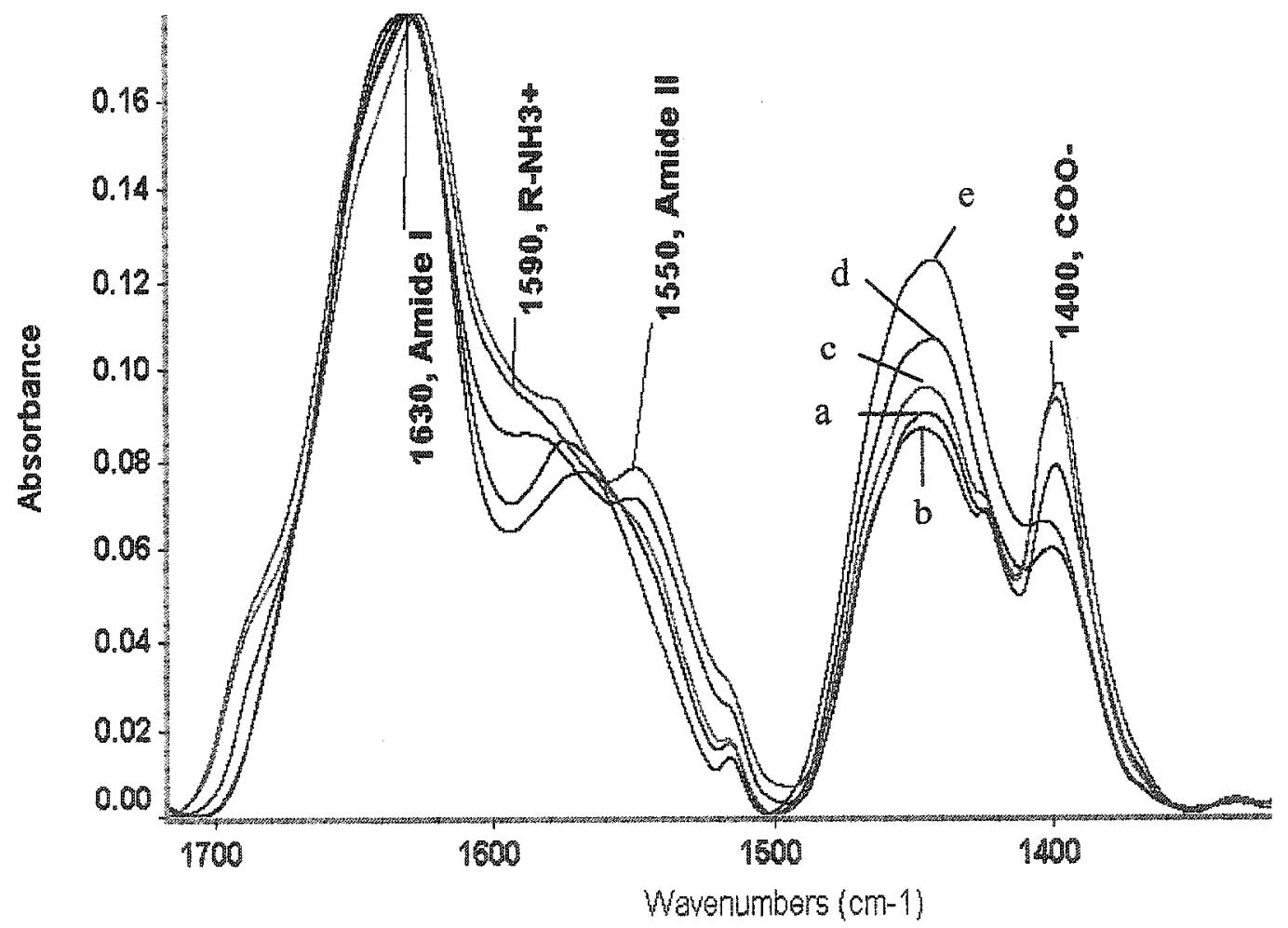

Figure 3.4: Baseline-corrected FTIR/ATR spectra of wash waters; a to e, first to fifth wash water. 


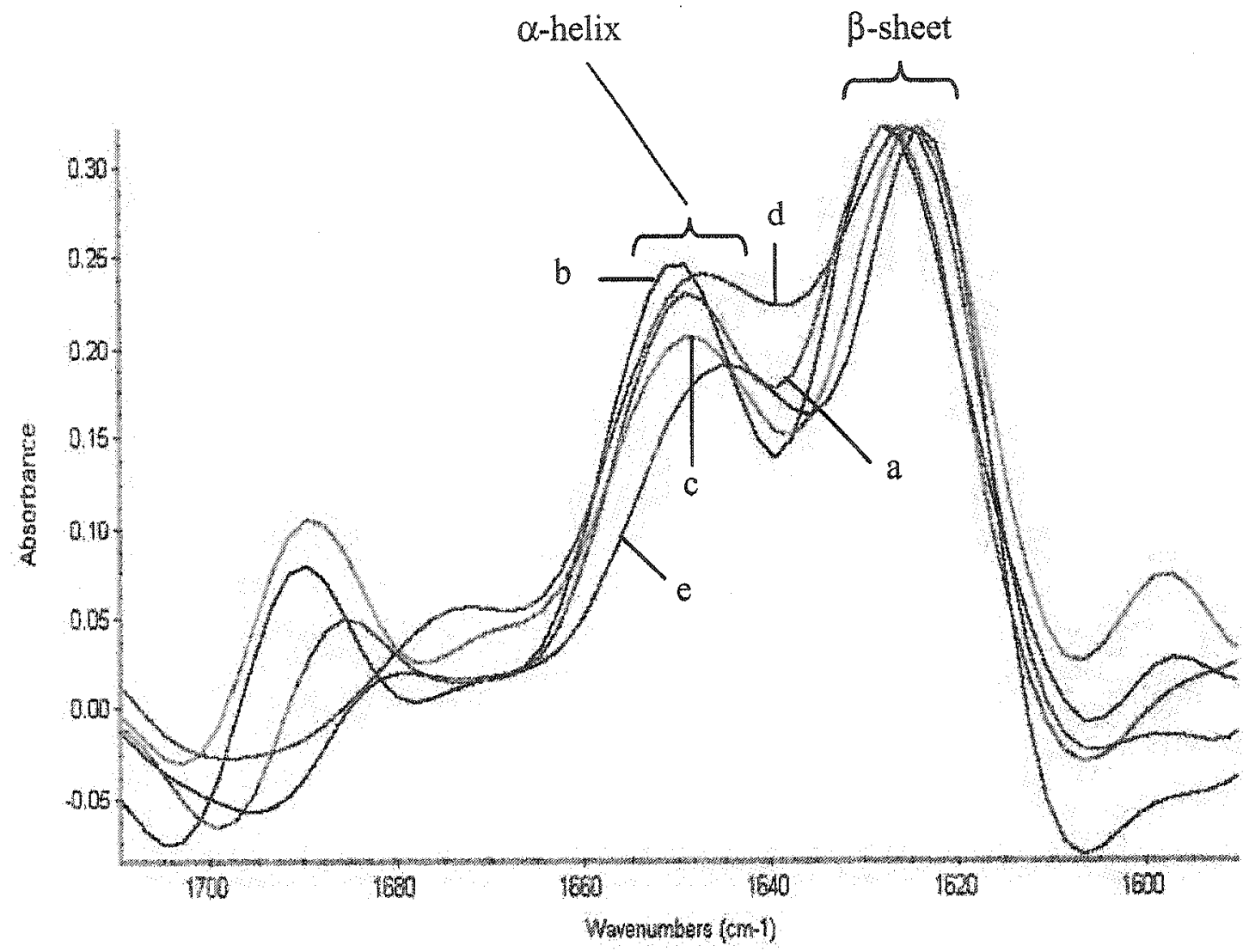

Figure 3.5: Deconvolved FTIR/ATR spectra of wash waters; a to e, first to fifth wash water. 


\subsubsection{DSC Analysis}

Interpretation of thermal analyses data from DSC presented difficulties in setting integration limits and thus building the baseline; similar problems have also been reported by other authors (Sych et al., 1990; Wright et al., 1977, and Hsu et al., 1993). Nevertheless, two endothermic transitions were differentiated in the range of $32-65^{\circ} \mathrm{C}$ and $40-85^{\circ} \mathrm{C}$ (Figure 3.6). The first transition (between 32 and $65^{\circ} \mathrm{C}$ ) consisted of several overlapping subtransitions resulting from the thermal denaturation of the different myosin domains and several sarcoplasmic proteins (Figure 3.6a) (Herrera et al., 2001). The second transition (between 40 and $85^{\circ} \mathrm{C}$ ) may be attributed to the denaturation of the thin filament proteins, mainly actin (Figure 3.6b)

The results suggest that myofibrillar proteins were removed after three washing cycles. Primarily sarcoplasmic proteins were removed in the $1^{\text {st }}$ washing cycle, and mainly actin was removed in the $5^{\text {th }}$ cycle. 

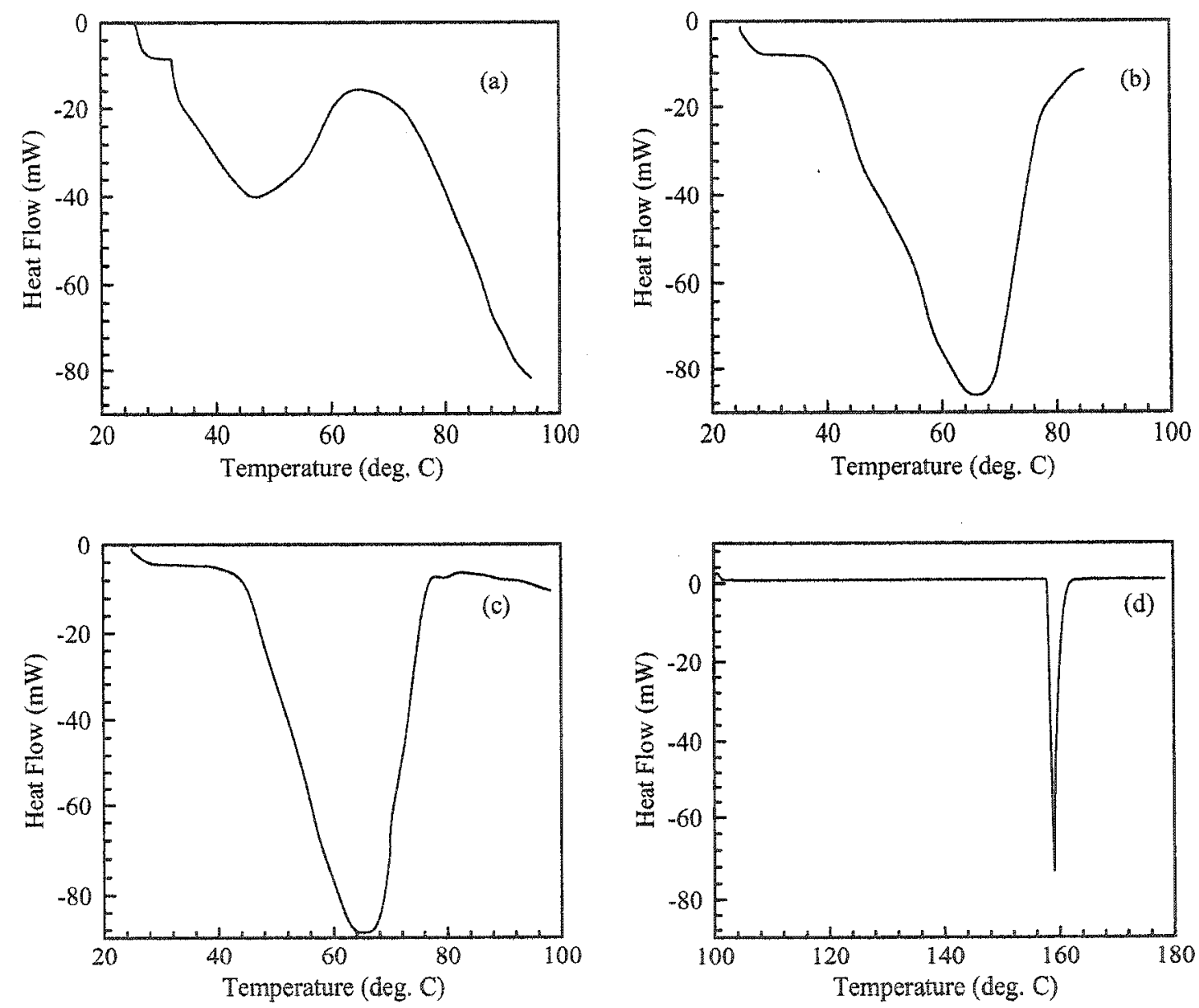

Figure 3.6: DSC thermograms of wash waters and standards; (a) $1^{\text {st }}$ wash water, (b) $5^{\text {th }}$ wash water, (c) actin (protein standard), (d) indium (reference standard). 


\subsubsection{Protein Changes in Minced Fish During Preparation of Surimi}

\subsubsection{Native-PAGE}

Figure 3.7 shows the native-PAGE patterns of minced fish and surimi from each washing step after 2 years of storage at $-20^{\circ} \mathrm{C} ; 6$ and 4 major bands were identified in minced fish and surimi (surimi $5^{\text {th }}$ ), respectively. The estimated molecular weights and presumptive identification of the main bands are shown in Table 3.3. The native-PAGE pattem of surimi from each cycle indicates that three washing cycles were adequate to prepare surimi since the surimi from the third washing cycle appears to have the same protein profile as that from the fifth washing cycle. Figure 3.7 shows that the major portion of sarcoplasmic proteins is fairly soluble and is removed during the initial washing steps. Subsequent washing could remove the residual sarcoplasmic proteins along with some myofibrillar proteins.

A comparison of minced fish and surimi native-PAGE patterns (Figure 3.7) indicates that bands $B$ ( $\alpha$-actinin) and $D$ (actin) are not present in surimi. The major band which disappeared during the process of making surimi is band D with MW of $\sim 43 \mathrm{kDa}$, which is considered to be actin. This may be explained by the fact that actin exists in both monomer (G-actin) and polymer forms (F-actin) (Park et al., 1997). It is likely that during surimi preparation, because of changes in the enviromment around $G$ actin including ionic strength and solubility, G-actin forms F-actin which was observed as bands with MW between $\sim 100$ and $\sim 300 \mathrm{kDa}$. Band D, possibly actin, disappeared after the second wash step. Furthermore, fading of band F (MLC) was observed after the $3^{\text {rd }}$ washing cycle (Figure 3.7 ). 


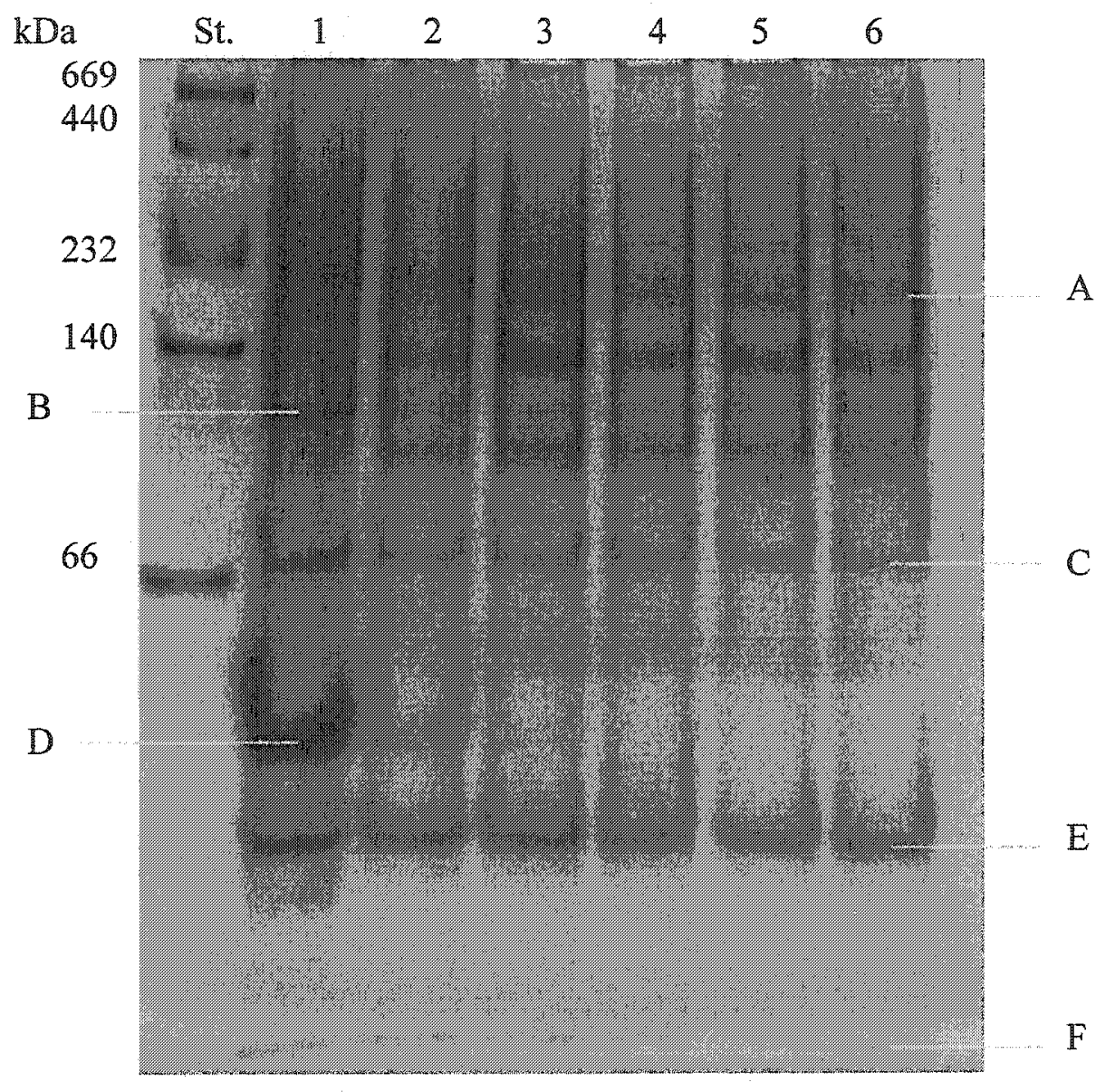

Figure 3.7: Native-PAGE patterns of minced fish and surimi; 1 minced fish; 2-6 first to fifth surimi (after 2 years of storage); St. HMW standard. A: myosin heavy chain; B: $\alpha$ actinin; $C$ : tropomyosin; D: actin; $\mathrm{E}$ and $\mathrm{F}$ : myosin light chains. 
Table 3.3: Molecular weight and presumptive identification of bands present in nativePAGE electrophoretic pattern of minced fish and surimi.

\begin{tabular}{|c|c|c|c|}
\hline Band & Relative mobility & $\begin{array}{c}\text { Estimated MW } \\
(\mathbf{k D a})\end{array}$ & Presumptive Identity \\
\hline A & 0.226 & 230 & Myosin heavy chain \\
\hline B & 0.328 & 127 & a-actinin \\
\hline C & 0.422 & 72 & tropomyosin \\
\hline D & 0.531 & 43 & actin \\
\hline E & 0.625 & 23 & MLC \\
\hline F & 0.758 & 12 & MLC \\
\hline
\end{tabular}

According to the classical muscle protein chemistry, sodium chloride $(0.3-0.6$ $M$ ) is needed to solubilize myofibrillar proteins (Park et al., 1997). However, recent studies indicate that a significant amount of myofibrillar proteins is solubilized in a solution with very low ionic strength (Park et al., 1997; Stefansson and Hultin, 1994).

When $10 \%$ homogenous native.PAGE was used to monitor the protein profile during surimi preparation, the same results were observed, i.e. multiple bands appeared at the top of the gel (Figure 3.8). In is worth mentioning that the same pattern was observed when an actin standard was used for comparison. Furthermore, it is noted that actin can also be removed during surimi preparation. Neither homogeneous nor gradient native-PAGE could detect standard myosin and MHC. This may be due to the fact that the native form of myosin is filamentous and insoluble. 


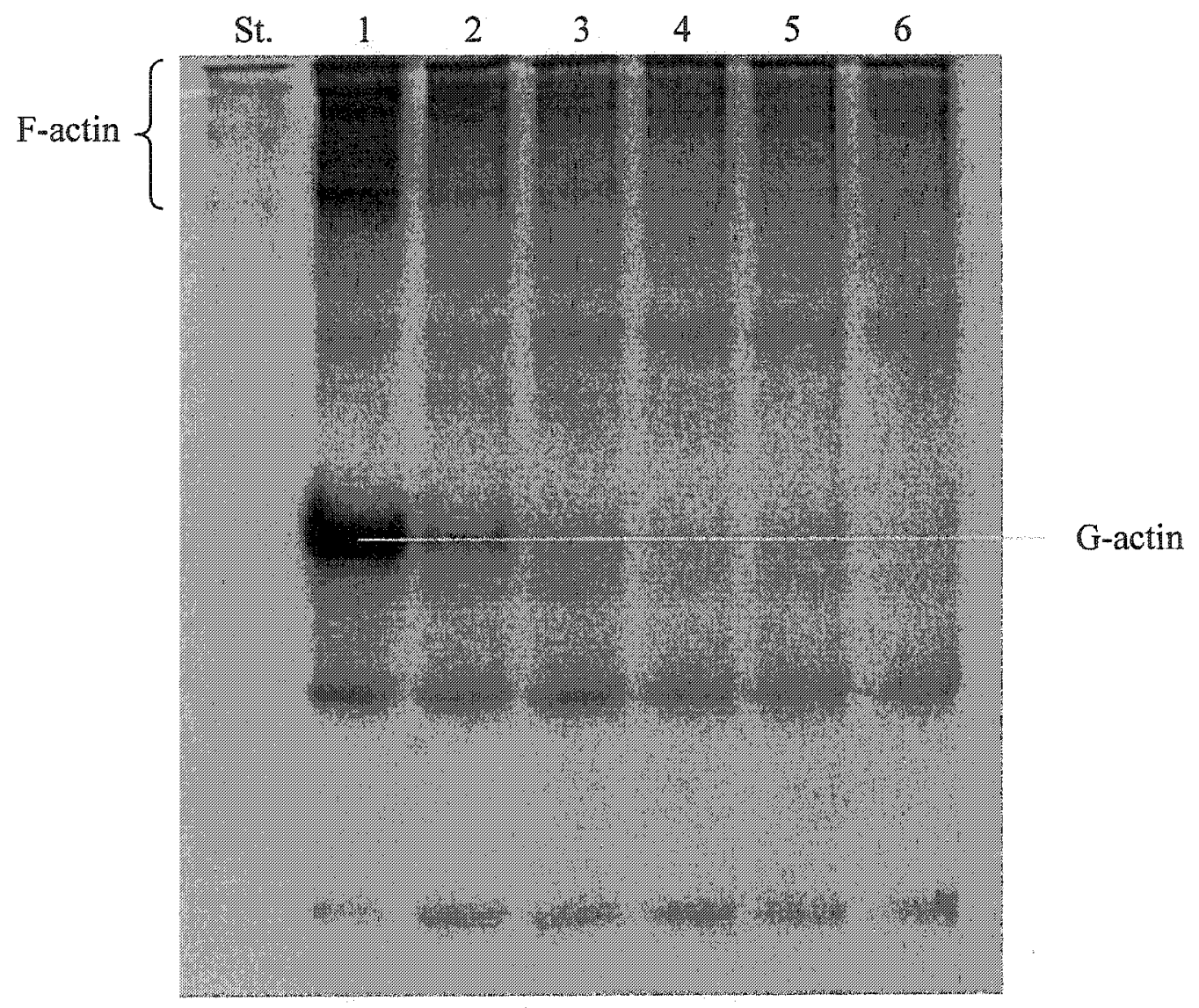

Figure 3.8: Native-PAGE patterns of minced fish and surimi; St. actin; 1 minced fish; 2 to 6 first surimi to fifth surimi (at time 0 ). 


\subsubsection{SDS-PAGE}

The SDS-PAGE patterns of minced fish and surimi from each washing step after 2 years of storage at $-20^{\circ} \mathrm{C}$ are shown in Figure 3.9 . The molecular weights of the fractions tentatively identified are shown in Table 3.4. The intensity of myofibrillar proteins, particularly $\mathrm{MHC}$ (band B) and actin (band F), are higher in surimi compared to minced fish. Figure 3.9 also shows the disappearance of five bands with $\mathrm{MW}$ of 95 , $65,54,27$ and $13 \mathrm{kDa}$ during surimi preparation. Myoglobin (band $\mathrm{N}$ ), a hemoprotein that accelerates the initiation of fat autoxidation, is removed during the initial step of washing. SDS-PAGE results showed that the relative amount of MHC increased as the washing cycle was repeated. Our experiments also indicate that a sufficient washing time should be allowed to increase washing efficiency.

\subsubsection{FTIR/ATR Analysis}

In this part of the investigation the positions and relative intensities of the amide I' band components in the wavenumber region of 1700 to $1600 \mathrm{~cm}^{-1}$ in the deconvolved infrared spectra of the proteins were studied. The amide I band, referred to as the amide I' band when the spectra of the proteins are recorded in $\mathrm{D}_{2} \mathrm{O}$, is the most frequently employed band in the elucidation of the secondary structure of proteins. The amide I band represents primarily the $\mathrm{C}=\mathrm{O}$ stretching vibrations of the amide groups coupled to the in-plane $\mathrm{NH}$ bending and $\mathrm{CN}$ stretching modes. The exact frequency of this vibration depends on the nature of hydrogen bonding involving the $\mathrm{C}=\mathrm{O}$ and NH moieties (Jackson and Mantsch, 1995; Surewicz et al., 1993; Surewicz and Mantsch, 1988). The secondary structures of proteins may be determined from 


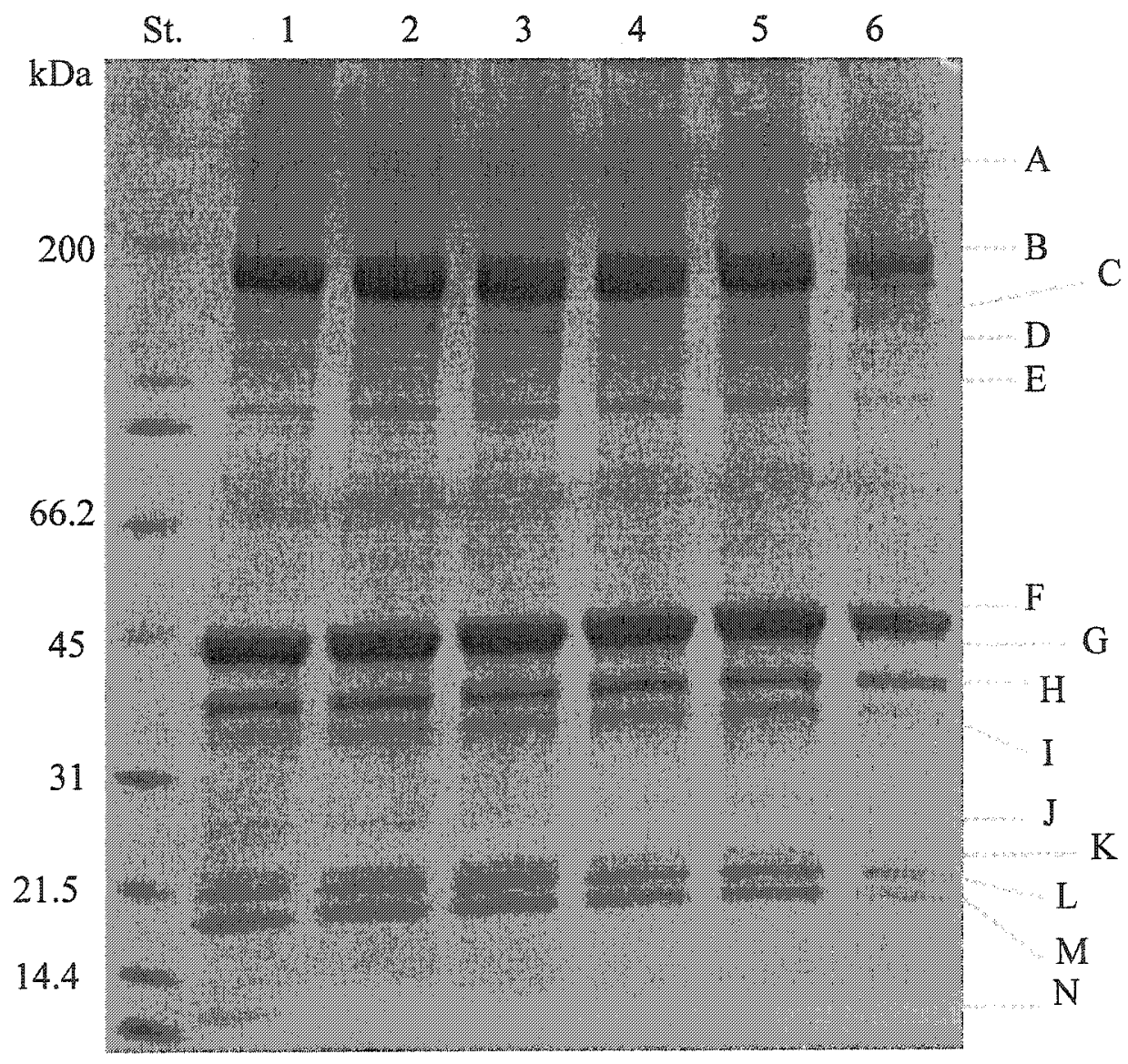

Figure 3.9: SDS-PAGE patterns of minced fish and surimi; 1 minced fish; $2-6$ first to fifth surimi (after 2 years of storage); St. broad range standard. A: myosin aggregate; B: myosin heavy chain; C: m-protein; D: c-protein; $E$ : $\alpha$-actinin; F: actin; $G$ : creatine kinase; $\mathrm{H}$ : $\beta$-tropomyosin; I: $\alpha$-tropomyosin; J, $\mathrm{K}, \mathrm{L}$, and $\mathrm{M}$ : myosin light chains; $\mathrm{N}$ : myoglobin. 
Table 3.4: Molecular weights and presumptive identification of bands present in SDSPAGE electrophoretic patterns of minced fish and surimi.

\begin{tabular}{|c|c|c|}
\hline Band & $\begin{array}{c}\text { Calculated MW } \\
(\mathrm{kDa})\end{array}$ & Presumptive Identity \\
\hline A & 223 & Myosin aggregate \\
\hline B & 194.1 & Myosin heavy chain \\
\hline C & 154.6 & M-protein \\
\hline D & 131.3 & C-protein \\
\hline E & 99.6 & a-actinin \\
\hline F & 46.3 & Actin \\
\hline G & 43.8 & Creatine kinase \\
\hline H & 39.8 & $\beta$-tropomyosin \\
\hline I & 36.9 & $\alpha$-tropomyosin \\
\hline$J$ & 26.7 & MLC \\
\hline K & 23.2 & MLC \\
\hline L & 21.7 & MLC \\
\hline M & 19.4 & MLC \\
\hline N & 13 & Myoglobin \\
\hline & & \\
\hline
\end{tabular}


deconvolved spectra based on the amide I' band assignments consisting of 1660-1648 $\mathrm{cm}^{-1}$ ( $\alpha$-helix), and 1640-1625 $\mathrm{cm}^{-1}$ (intramolecular $\beta$-sheet) (Jackson and Mantsch, 1995; Ismail et al., 1992; Surewicz and Mantsch, 1988). It should be stressed that these correlations are guidelines only. Significant differences exist between the spectra of the protein in solution and as dry and hydrated films (Jackson and Mantsch, 1995). Thus, the use of these correlations should be guided by common sense and information obtained from other sources (Wilder et al., 1992). In this study, the regions between 1658-1647 and $1635-1624 \mathrm{~cm}^{-1}$ were assigned to $\alpha$-helix and intramolecular $\beta$-sheet structures, respectively.

The area under the spectra in each region was obtained and then divided by the total area of the amide I' region to calculate the percentage of each conformation. Furthermore, the ratio of $\alpha$-helix to $\beta$-sheet structure content was calculated. In general, the areas of the components around $1635 \mathrm{~cm}^{-1}$ (associated with the $\beta$-sheet structure) are more easily measured than the components close to 1653 or $1646 \mathrm{~cm}^{-1}$ (associated with helical portions and 'random' structures, respectively) (Byler and Susi, 1986).

The FTIR/ATR spectra of minced fish and surimi without the addition of $\mathrm{D}_{2} \mathrm{O}$ showed that the protein profile, as reflected by the relative intensities of the amide I band components, in minced was different from that in surimi (data not shown). The subtraction of the FTIR/ATR spectra of the $3^{\text {rd }}$ and the $5^{\text {th }}$ surimi at time 0 revealed no major differences, indicating three washing cycles were sufficient to prepare surimi. However, the absorbances obtained by applying freeze-dried samples on the crystal were very low, making the interpretation of results complicated. Thus, to improve the 
signal-to-noise ratio and to obtain higher absorbances, the experiment was repeated using $\mathrm{D}_{2} \mathrm{O}$ for sample preparation, the results of which are shown in Figure 3.10.

As indicated in Figure 3.10, the amide I' band in the spectrum of minced fish at time 0 had structures that can be attributed to diverse conformations. After three cycles of successive washing to prepare surimi (surimi $3^{\text {rd }} t=0$ ), the amide I' band revealed an increase in $\alpha$-helix content (relative to $\beta$-sheet) and contained more unordered or random coil structure $\left(1641-1645 \mathrm{~cm}^{-1}\right)$. As seen in Figure 3.10 , surimi $3^{\text {rd }}$ at time 0 $(\mathrm{t}=0)$ had more $\alpha$-helix content than minced fish due to the washing process in which compounds containing $\beta$-sheet structure were removed; thus, the ratio of $\alpha$-helix to $\beta$ sheet structure increased, It is also observed that a slight increase in $\alpha$-helical and a decrease in $\beta$-sheet structure content occurred in surimi after five cycles of washing resulting in an increase in the ratio of $\alpha$-helix to $\beta$-sheet structure compared to surimi after three cycles of washing. This increase may be due to the helical nature of myosin, and the relative enrichment of myosin obtained by processing Alaska pollock minced into surimi. This increase may also be due to the aggregation of myosin heads because of changes in ionic strength. It appears that during the washing process the structure of myofibrillar proteins changes and the quality of surimi improves. The ETIR/ATR results suggest that it may be possible to obtain an index of quality and probably texture by calculating the ratio of $\alpha$-helical to $\beta$-sheet content. 

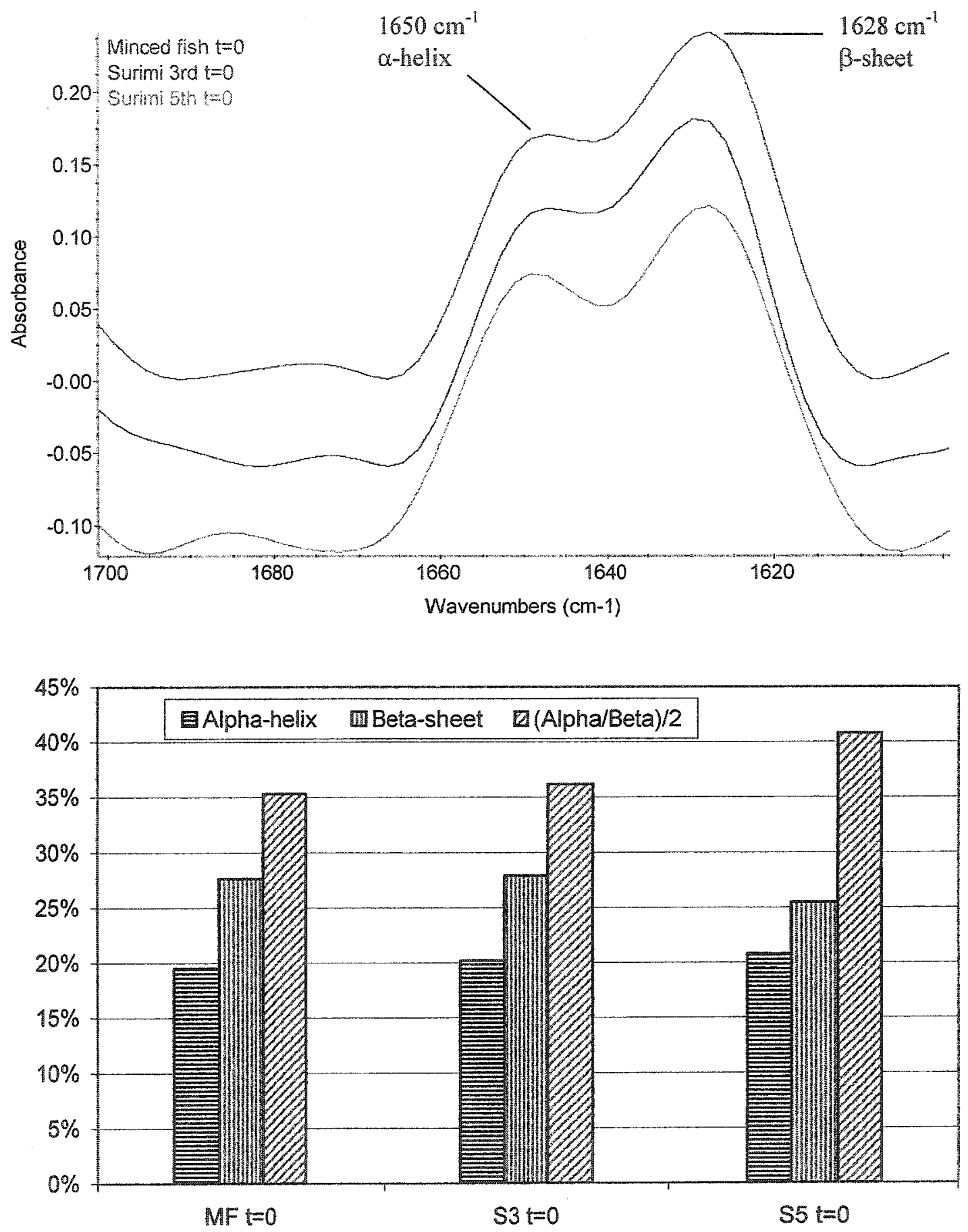

Figure 3.10: Stacked plot of deconvolved FTIR/ATR spectra of minced fish and surimi with the addition of $\mathrm{D}_{2} \mathrm{O}$ (top); percentage of $\alpha$-helix, $\beta$-sheet structures and their ratio (bottom). The spectra have been offset for clarity. 


\subsubsection{DSC Analysis}

Figure 3.11(a) shows the thermograms obtained for frozen minced fish, indicating that the protein denaturation was irreversible. This is evident from the fact that there is no peak in the thermogram during the cooling phase. The frozen minced fish DSC thermogram also revealed two clearly differentiated endothermic transitions. The first transition occurred between 32 and $75^{\circ} \mathrm{C}$, and the second transition occurred between 78 and $89^{\circ} \mathrm{C}$. These results were comparable to the findings of Herrera et al. (2001) who reported two endothermic transitions for minced blue whiting muscle; the first from 30 to $60^{\circ} \mathrm{C}$, and the second one from 65 to $85^{\circ} \mathrm{C}$.

As mentioned previously (section 3.2 .3 .3 .) it was very difficult to differentiate the endothermic peaks especially in lyophilized samples; this problem has also been reported by other researchers. Park and Lanier (1989) reported that a very broad single peak was obtained for all of the myosin and actin fractions. This indicates that thermal denaturation of these proteins does not occur suddenly at a specific temperature but, rather, gradually over a wide temperature range. In their study, the DSC endothermic peaks at about $52^{\circ} \mathrm{C}$ and $60^{\circ} \mathrm{C}$ were verified as being derived from denaturation of myosin and actin, respectively. Purification of actin and myosin yielded thermograms evidencing a single peak, whose enthalpy of denaturation increased with further purifications. Crude actin and pure actin exhibited single peaks at $59.3^{\circ} \mathrm{C}$ and $61.4^{\circ} \mathrm{C}$, respectively. 

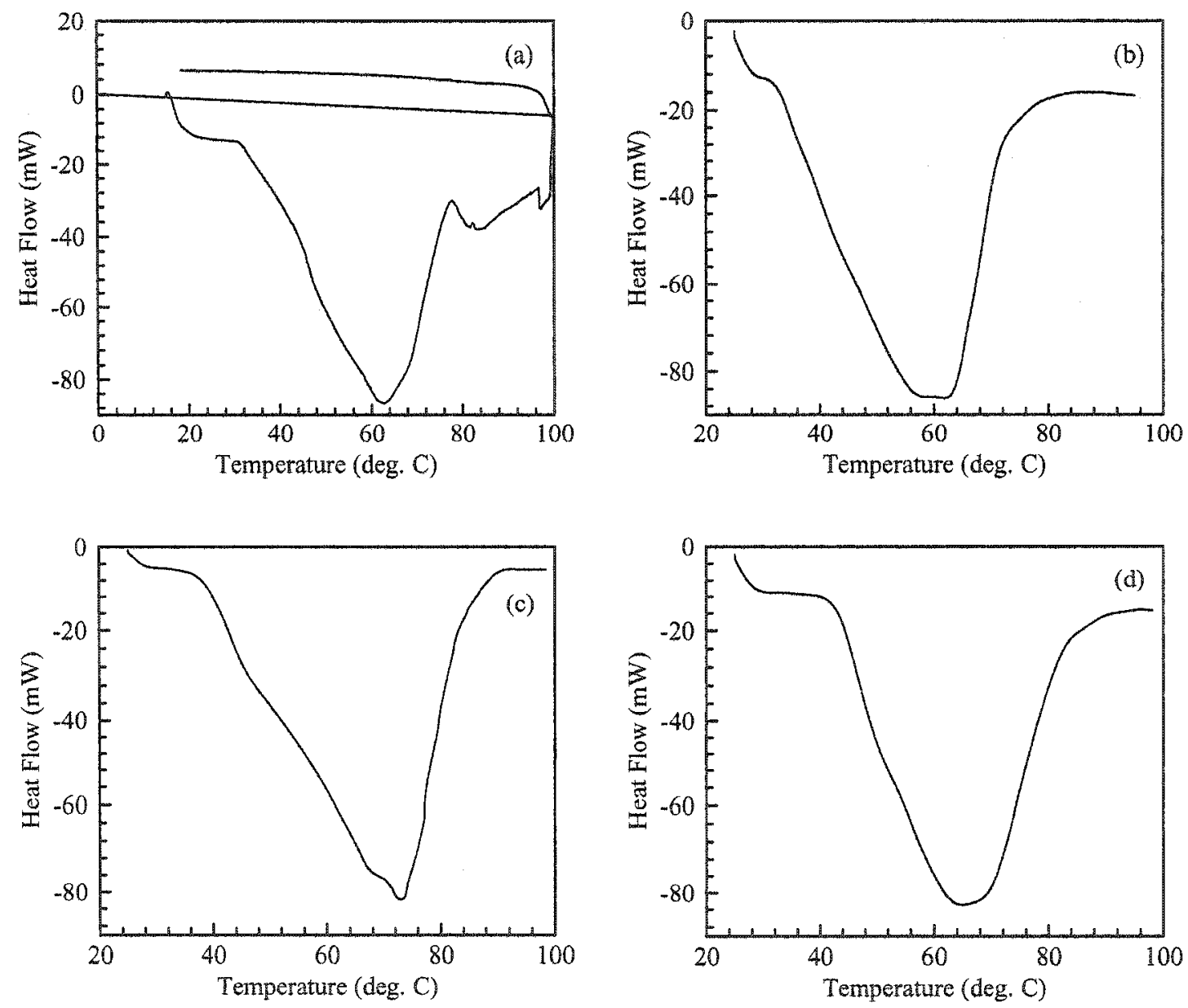

Figure 3.11: DSC thermograms of (a) frozen minced fish, (b) freeze-dried minced fish, (c) standard myosin, (d) freeze-dried surim; heating rate at $10^{\circ} \mathrm{C} / \mathrm{min}$. 
However, another study by AbuDagga and Kolbe (1997) showed that denaturation of myosin and actin occurred at $45^{\circ} \mathrm{C}$ and $75^{\circ} \mathrm{C}$, respectively. Sano et al. (1988) also reported that the DSC analysis of myosin showed broad endothermic regions at $38-56^{\circ} \mathrm{C}$ and $56-67^{\circ} \mathrm{C}$, suggesting that the conformation of myosin molecules changed in these temperature ranges. They proposed that most of the myosin molecule may have unfolded and become a random coil. Also in a study by Togashi et al. (2002), the DSC deconvolution analysis for Walleye pollock myosin, gave three endotherms where the highest endothermic peak was observed at $33.7^{\circ} \mathrm{C}$, followed by those at 41.3 and at $28.2^{\circ} \mathrm{C}$. In this study, it was also reported that denaturation of Walleye pollock myosin was partially reversible.

In the DSC thermograms of freeze-dried minced fish and surimi in buffer (Figures $3.11 \mathrm{~b}$ and $3.11 \mathrm{~d}$ ), the transition became less clearly defined and appeared as a broad peak, which occurred between 32 and $77^{\circ} \mathrm{C}$ for minced fish and 41 to $87^{\circ} \mathrm{C}$ for surimi. Figure $3.11 \mathrm{c}$ represents the thermogram of standard myosin. In order to differentiate more clearly among transitions, a heating rate of $5^{\circ} \mathrm{C} / \mathrm{min}$ was used for further DSC analyses.

Analyses at the lower heating rate $\left(5^{\circ} \mathrm{C} / \mathrm{min}\right)$, shown in Figure 3.12 , revealed a shift in the thermal transition of actin to a higher temperature of $63^{\circ} \mathrm{C}$ in surimi (Figure 3.12b) compared to that in minced fish at $60^{\circ} \mathrm{C}$ (Figure 3.12a), indicating greater protein stability in surimi compared to minced fish. 

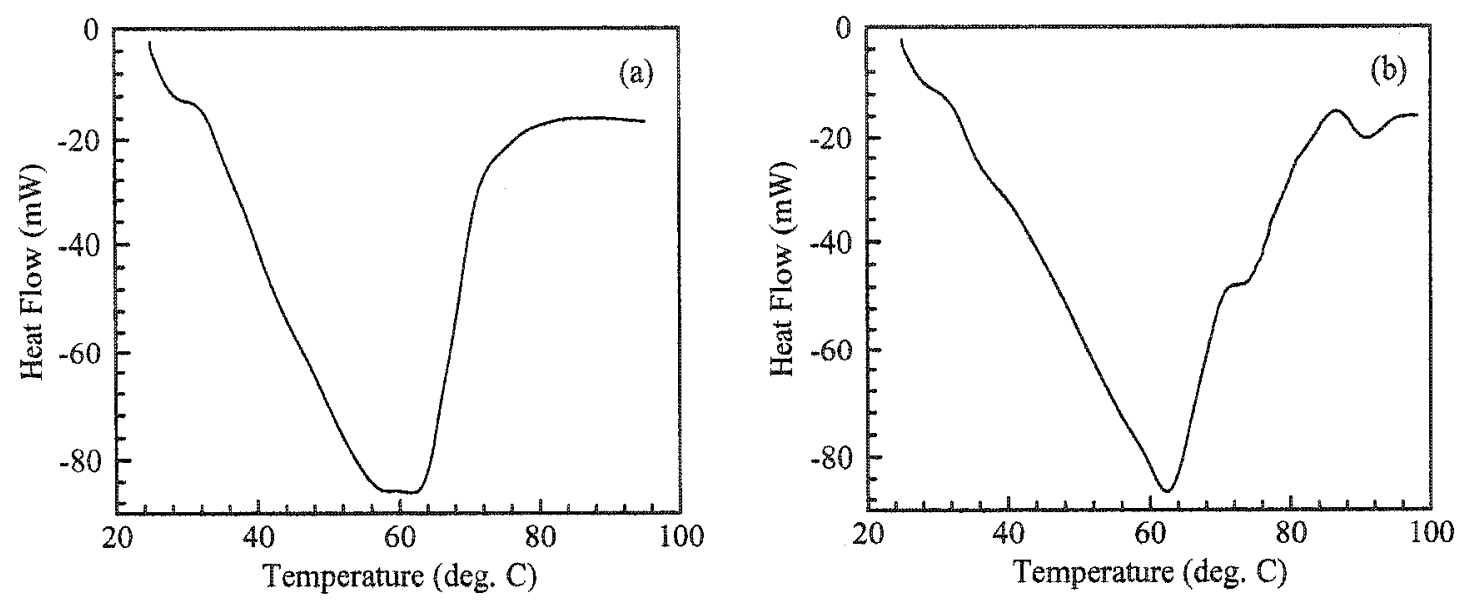

Figure 3.12: DSC thermograms of (a) minced fish at time 0 , (b) surimi $5^{\text {th }}$ at time 0 ; heating rate at $5^{\circ} \mathrm{C} / \mathrm{min}$.

\subsubsection{Changes During Frozen Storage of Surimi}

\subsubsection{Native-PAGE}

Native-PAGE (Figure 3.13) shows the protein profile of minced fish and surimi $5^{\text {th }}$ at time 0 , and after 1 and 2 years storage at $-20^{\circ} \mathrm{C}$ with slow and rapid freezing. The results indicate that surimi is quite stable during frozen storage at $-20^{\circ} \mathrm{C}$ and also slow and rapid freezing had no apparent effect on protein degradation. 


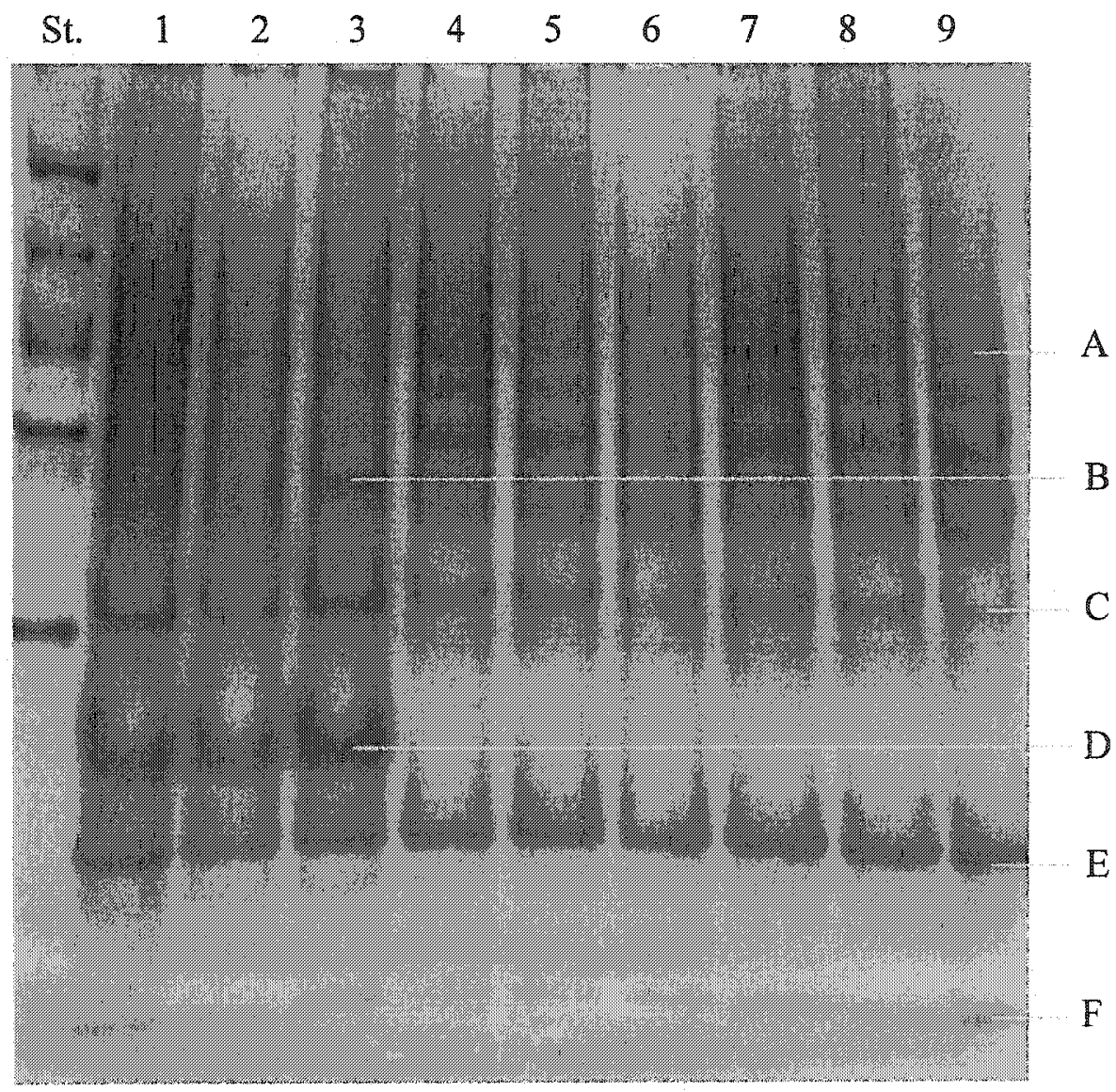

Figure 3.13: Native-PAGE patterns of minced fish and surimi at time 0 , and after 1 and 2 years of storage at $-20^{\circ} \mathrm{C}$, respectively; $1-3$ minced fish; $4-6$ surimi $5^{\text {th }}$ slow frozen; $7-9$ surimi $5^{\text {th }}$ rapid frozen; St. HMW standard. A: myosin heavy chain; B: $\alpha-$ actinin; $\mathrm{C}$ : tropomyosin; D: actin; $\mathrm{E}$ and $\mathrm{F}$ : myosin light chains. 


\subsubsection{SDS-PAGE}

Figure 3.14 shows the SDS-PAGE patterns of minced fish and surimi $5^{\text {th }}$ on 4 $20 \%$ gradient gel at time 0 , and after 1 and 2 years of storage at $-20^{\circ} \mathrm{C}$. The results showed slight changes in protein subunits particularly in the myosin light chains (MLC) zone. Diffusion of some MLC bands, with MW of 23.2 and 21.7 was observed; this was also reported by Jasra et al. (2001). MHC, actin and tropomyosin were relatively stable in surimi samples compared to minced fish. Overall, it appears that both minced fish and surimi are quite stable during frozen storage at $-20^{\circ} \mathrm{C}$ for 2 years. Figure 3.14 also shows that minced fish and surimi frozen by liquid air (rapid freezing) at time 0 , and after 1 and 2 years of storage at $-20^{\circ} \mathrm{C}$ had no significant difference with minced fish and surimi samples frozen slowly at $-20^{\circ} \mathrm{C}$ in freezer. However, in some cases, higher intensity of bands were observed in rapid frozen samples suggesting more stability of protein using liquid air (refer to lanes 4-6 compared to lanes 7-9 in Figure 3.14). Large ice crystals form in the critical temperature range of -1 to $-5^{\circ} \mathrm{C}$, and their formation can be prevented by rapid freezing (Lanier and Lee, 1992).

When Pacific rockfish (Sebastes sp.) stored at $-5^{\circ} \mathrm{C},-12^{\circ} \mathrm{C}$, and $-20^{\circ} \mathrm{C}$, the decrease in ATPase activity was influenced more by the temperature of storage than by the initial freezing rate (Mackie, 1993). Freezing has been shown to have a damaging effect on isolated proteins and enzymes in general. Rabbit myosin, on freezing in liquid air, for example, lost about $40 \%$ of its ATPase activity and after five freeze-thaw cycles the activity disappeared completely. However, in situ enzymes seem to be more resistant to the effects of freezing and thawing (Mackie, 1993). 


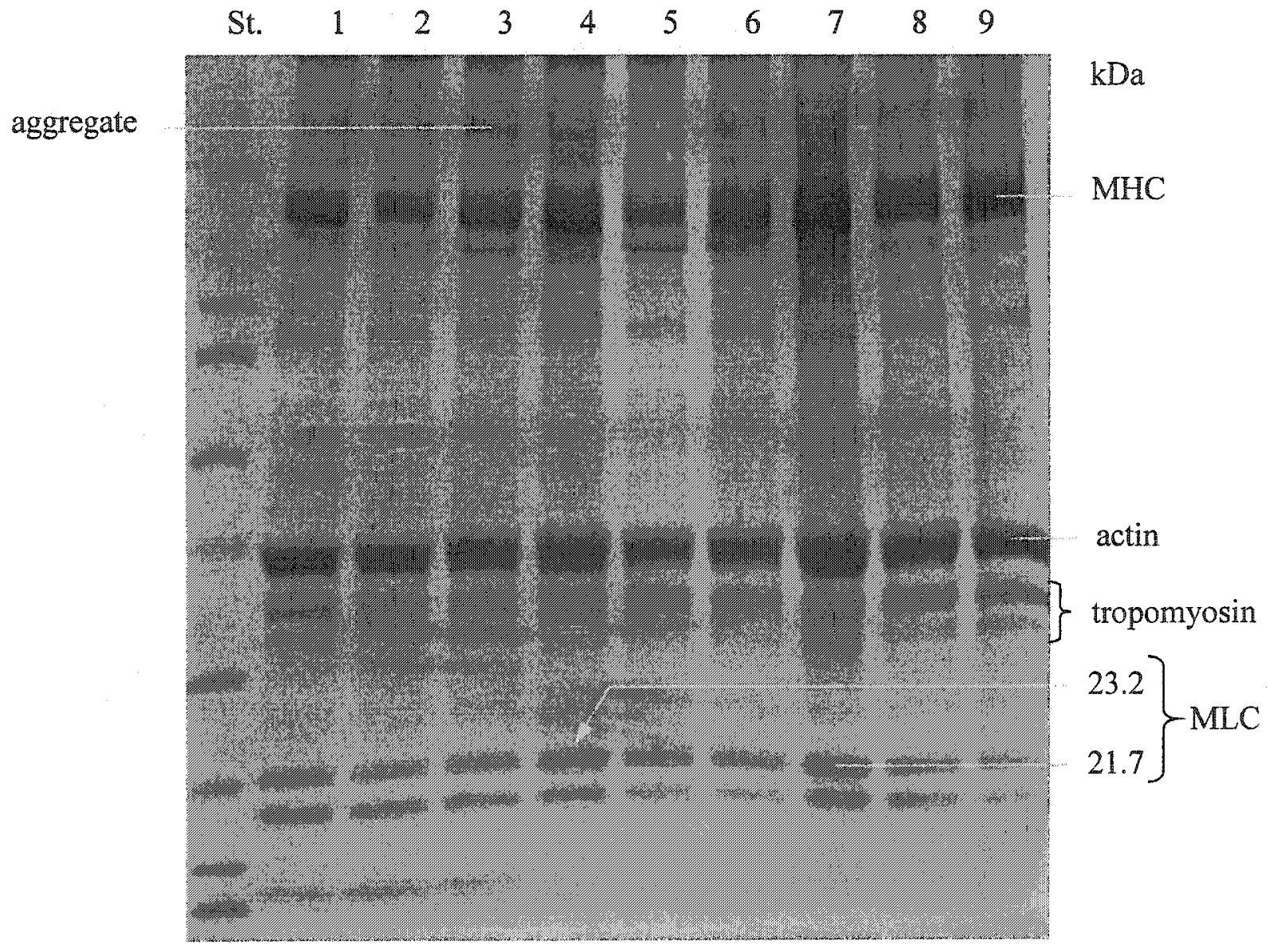

Figure 3.14: SDS-PAGE patterns of minced fish and surimi at time 0 , and after 1 and 2 years of storage at $-20^{\circ} \mathrm{C}$, respectively; $1-3$ minced fish; $4-6$ surimi $5^{\text {th }}$ slow frozen; $7-9$ surimi $5^{\text {th }}$ rapid frozen; $S t$. broad range standard. 
It should be noted that SDS-PAGE were done on both slow and rapid frozen samples every month over the course of the 2-year study, but the results are not shown here due to their high degree of similarity. This may be due to the fact that even severely denatured fish flesh will dissolve in SDS solution (Mackie, 1993). Therefore, the SDS electrophoretic pattern of the proteins and subunits are remarkably unchanged compared to fresh unfrozen muscle. Briefly, the electrophoretic patterns provide evidence mainly for the formation of hydrogen and hydrophobic bonds on frozen storage (Mackie, 1993).

Frozen fish that has undergone deterioration during storage appears to accumulate high molecular weight protein aggregates. These aggregates are stabilized by hydrophobic interactions, disulfide bonds and other covalent crosslinks. They involve mainly myosin and actin, and are initially extractable in salt solutions. Such aggregates tend to grow in number and size making some aggregates become inextractable even in the presence of SDS and mercaptoethanol (Careche and Li-Chan, 1997). There is some evidence for high molecular weight aggregates on the SDS electrophoresis, usually observed as protein staining on the top of PAGE gels and also between the MHC and the top of the gels (Mackie, 1993).

As shown in Figure 3.14, a cross-linked protein with MW of $223 \mathrm{kDa}$ was observed in our SDS-PAGE pattems, which is in consistence with the findings of Ragnarsson \& Regenstein (1989) who reported the appearance of a cross-linked protein of $\sim 280 \mathrm{kDa}$ formed with a gadoid fish species (Gadidae family) during frozen storage. They concluded that the best possibility was that the cross-linked protein is myosin with additional protein(s). 


\subsubsection{FTIR/ATR Analysis}

Figure 3.15 shows the deconvolved FTIR/ATR spectra of surimi samples at time 0 and after 2 years of storage at $-20^{\circ} \mathrm{C}$. It indicates that the $\alpha$-helical content in surimi $3^{\text {rd }}$ samples decreased in slow frozen samples after 2 years of storage, but remained almost unchanged in rapid frozen samples during storage. There was also a decrease in $\beta$-sheet structure content in both the slow and rapid frozen surimi $3^{\text {rd }}$ samples, but this decrease was more significant in rapid frozen samples. Overall, the ratio of $\alpha$-helix to $\beta$-sheet structures decreased for slow frozen and increased for rapid frozen surimi $3^{\text {rd }}$ samples after two years of storage at $-20^{\circ} \mathrm{C}$.

Figure 3.15 also shows that there was a considerable loss of $\alpha$-helical structure relative to $\beta$-sheet content in surimi $5^{\text {th }}$ after 2 years of storage at $-20^{\circ} \mathrm{C}$; this loss was more significant in slowly frozen samples. Moreover, a comparison of the results for surimi $5^{\text {th }}$ samples and rapid frozen surimi $5^{\text {th }}$ samples both at time 0 indicates that the ratio of $\alpha$-helix to $\beta$-sheet structures increased after rapid freezing; this suggests that rapid freezing (using liquid air) caused immediate changes in protein structure. On the other hand, the results for the surimi $5^{\text {th }}$ samples after 2 years of storage indicate that the secondary structures of the proteins remained more stable in the rapid frozen samples compared to the slow frozen ones. This is indicated by the relatively small changes seen in the $\alpha$-helix and $\beta$-sheet percentages in surimi $5^{\text {th }} t=2 \mathrm{yr}$ LA (rapid frozen) compared with surimi $5^{\text {th }} t=0$ LA (rapid frozen), as opposed to larger changes in these values for surimi $5^{\text {th }}$ slow frozen samples during the same period (surimi $5^{\text {th }}$ $t=2$ yr compared with surimi $5^{\text {th }} t=0$ ). 

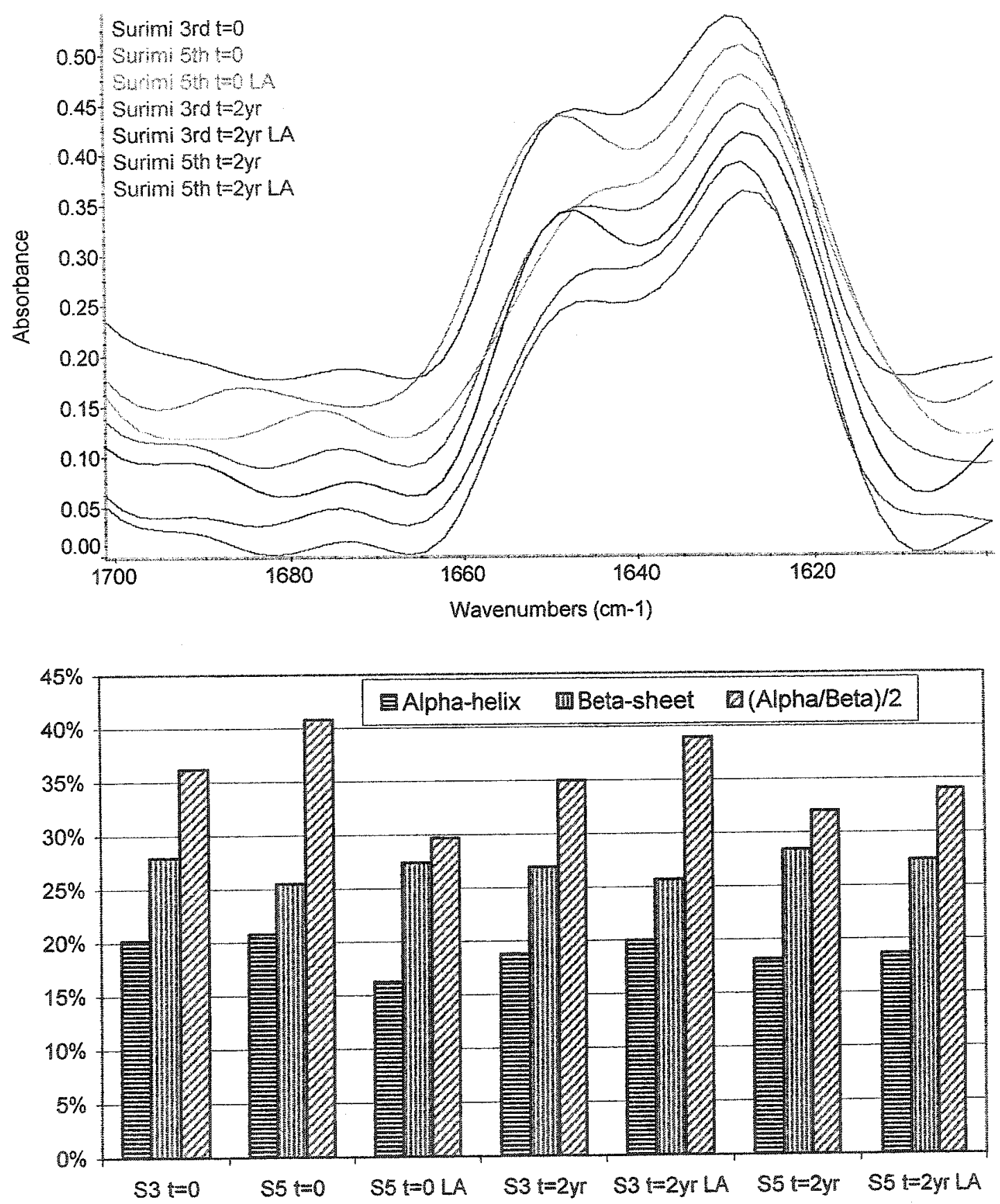

Tigure 3.15: Stacked plot of deconvolved FTIR/ATR spectra of surimi, at time 0 and after 2 years of storage, with the addition of $\mathrm{D}_{2} \mathrm{O}$ (top); percentage of $\alpha$-helix, $\beta$-sheet structures and their ratio (bottom). The spectra have been offset for clarity. 
It is observed that the percentage of $\alpha$-helix structure increased in the rapid frozen samples (LA) after 2 years of storage (surimi $5^{\text {th }} t=2 \mathrm{yr}$ LA compared to surimi $5^{\text {th }} t=0$ LA). This is in agreement with the results of a study by Sultanbawa and LiChan (2001), in which surimi from ling cod (Ophiodon elongatus) subjected to frozen storage at $-20^{\circ} \mathrm{C}$, after eight freeze-thaw cycles in the absence of cryoprotectants, showed increased percent $\alpha$-helix and disulfide content using Raman spectroscopy. They indicated that freezing resulted in an increase in the percentage of $\alpha$-helix from 40 to $60 \%$ compared to that observed before freezing. The $\mathrm{OH}$ stretching region also decreased in intensity, possibly due to the formation of ice crystals that resulted in dehydration of the protein and aggregation of the myosin heads.

No FTIR/ATR analysis on surimi was found in the literature. However, structural changes in hake (Merluccius merluccius L.) fillet as affected by freezing method and frozen storage temperature have been studied by Careche et al. (1999) also using Raman spectroscopy. These structural changes were then related to changes in texture and functionality. They reported that samples at $-10^{\circ} \mathrm{C}$ showed greater structural alteration than at $-30^{\circ} \mathrm{C}$ in terms of increase in $\beta$-sheet content at the expense of $\alpha$-helices. Using Raman spectroscopy, Careche and Li-Chan (1997) also showed that in myosin isolated from cod, structural changes occurred upon formaldehyde addition and frozen storage, involving loss of $\alpha$-helical content. Changes in vibrational modes assigned to aliphatic residues suggested involvement of hydrophobic interactions. Ramirez et al. (2000) proposed that frozen storage of myosin in suspension results in aggregation involving side-to-side interactions of the rod with a low extent of formation of disulfide bonds. However, when myosin is solubilized prior 
to frozen storage, mainly head-to-head interactions with a higher extent of formation of disulfide bonds are implicated in the aggregation.

\subsubsection{DSC Analysis}

The DSC thermograms of minced fish and surimi revealed a shift in the thermal transition of actin to lower temperatures during frozen storage, 60 to $53^{\circ} \mathrm{C}$ for minced fish (Figures $3.16 \mathrm{a}$ and $3.16 \mathrm{~b}$ ) and 63 to $59^{\circ} \mathrm{C}$ for surimi (Figures $3.16 \mathrm{c}$ and $3.16 \mathrm{~d}$ ), indicating destabilization of protein. As shown in Figure 3.17 there was also a shift in the thermal transition of actin to lower temperature $\left(64\right.$ to $\left.60^{\circ} \mathrm{C}\right)$ for rapid frozen surimi samples during frozen storage. The results indicate that rapid freezing of surimi using liquid air had no apparent effect on thermal stability of proteins during processing and storage. 

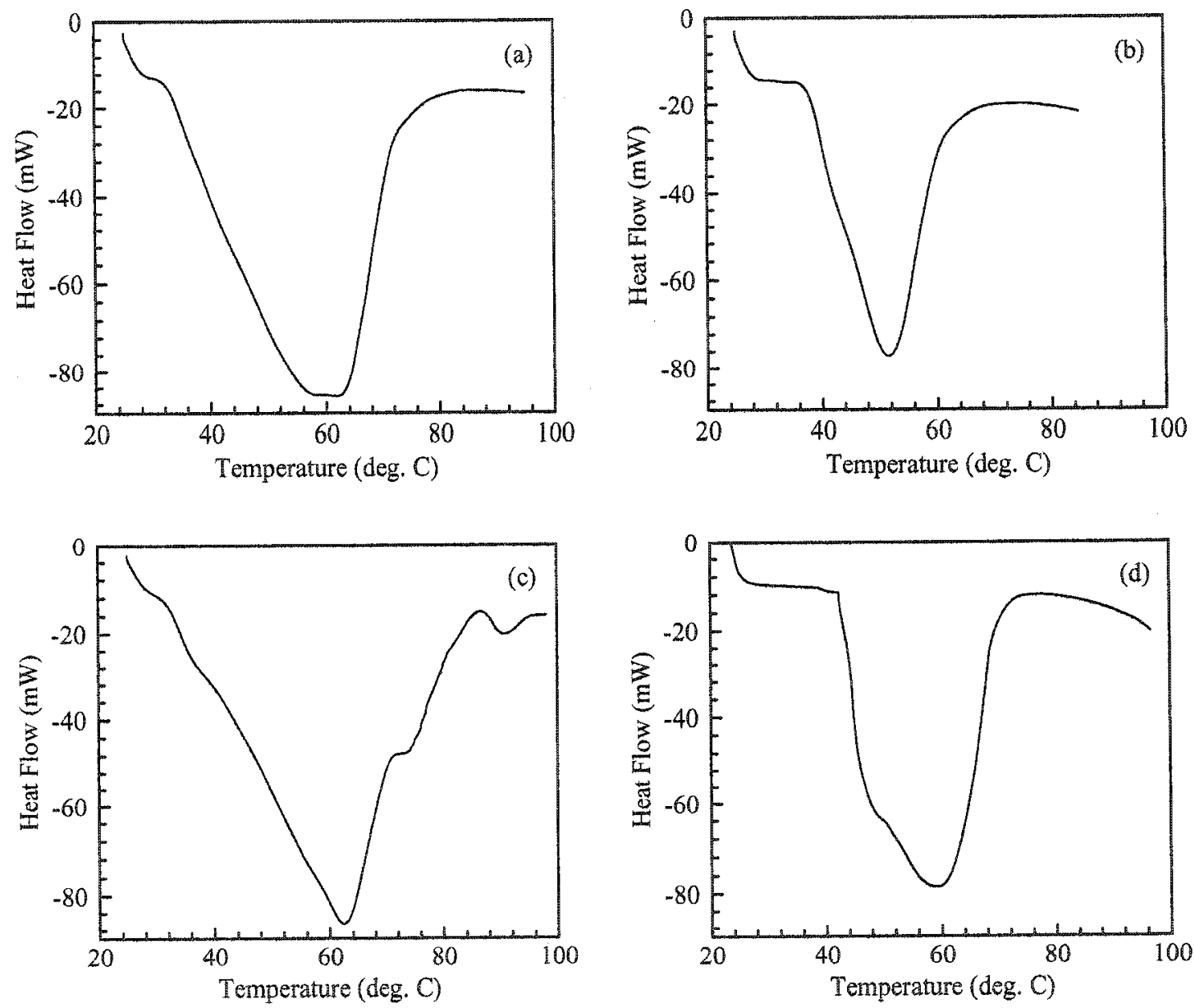

Figure 3.16: DSC thermograms of (a) minced fish at time $0,(b)$ minced fish after 2 years of storage, (c) surimi $5^{\text {th }}$ at time 0 , (d) surimi $5^{\text {th }}$ after 2 years of storage; heating rate at $5^{\circ} \mathrm{C} / \mathrm{min}$. 

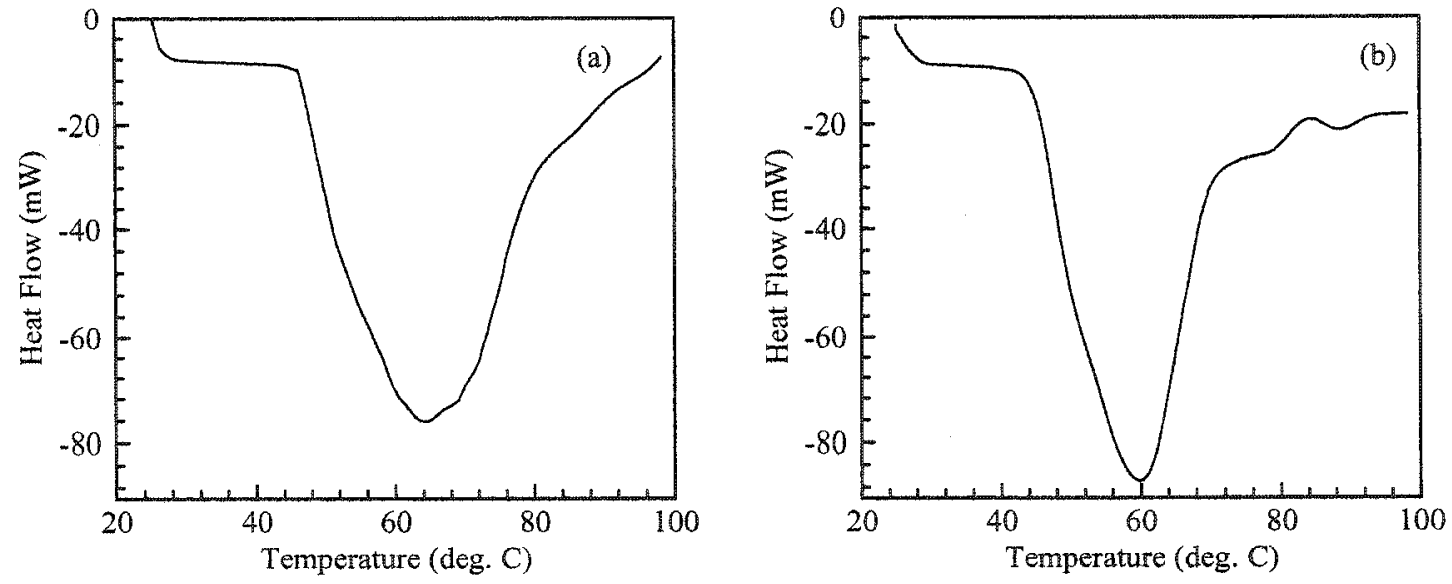

Figure 3.17: DSC thermograms of (a) rapid-frozen surimi $5^{\text {th }}$ at time 0 , (b) rapid frozen surimi $5^{\text {th }}$ after 2 years of storage at $-20^{\circ} \mathrm{C}$. 


\section{Chapter 4}

\section{EFFECT OF CRYOPROTECTANTS ON THE STABILITY OF PROTEINS IN SURIMI DURING STORAGE}

\subsection{INTRODUCTION}

In this part of the research different cryoprotectants were added to surimi in order to improve the stability of proteins during storage. Among the many available choices of additives, the following were selected as cryoprotectants to surimi during its preparation: whey protein concentrate (WPC), whey protein isolate (WPI), soy protein isolate (SPI), flaxseed meal (FM), and flaxseed protein (FP). The effects of these cryoprotectants on maintaining the proteins structure during frozen storage were investigated and compared to the market products. In addition, the effects of cryoprotectants on protein changes at $4^{\circ} \mathrm{C}$ were studied and compared to frozen storage at $-20^{\circ} \mathrm{C}$. As described in section 2.7 .2 .3 , the above-mentioned additives have been used mostly as functional ingredients in different food products; however, their application as cryoprotectants in surimi has not been reported in the literature. 


\subsection{MATERIALS AND METHODS}

\subsubsection{Preparation of Raw Surimi}

The procedure for preparation of surimi was similar to that described in section 3.1.2, with the following two modifications: (i) three washing cycles were used, and (ii) $0.2 \%$ salt was added to the third wash water.

\subsubsection{Treatment of Surimi with Cryoprotectants}

The following materials were used to treat surimi at a $3 \% \mathrm{wt} / \mathrm{wt}$ concentration: whey protein concentrate (Calpro Ingredients, Corona, CA), whey protein isolate (Rene Rivet Inc. Ingredients, Laval, QC), cryoprecipitated soy protein isolate (samples from previous work: Abdolgader, 2000), defatted crushed flaxseed meal (CanAmera Foods, Winnipegs, Manitoba), and defatted flaxseed protein (laboratory preparation). Flaxseed protein was added at two concentrations of $1 \%$ and $3 \%$ to raw surimi.

\subsubsection{Storage}

Samples were taken for further analyses from wash waters, minced fish, surimi from each cycle, and surimi with additives. Half of the samples of minced fish and surimi were stored at $-20^{\circ} \mathrm{C}$ for $6 \mathrm{mo}$, whilst the other half were stored at $4^{\circ} \mathrm{C}$ for $15 \mathrm{~d}$. Samples were taken after 6 mo storage at $-20^{\circ} \mathrm{C}$, and after 5,10 , and $15 \mathrm{~d}$ storage at $4^{\circ} \mathrm{C}$. A schematic diagram of surimi preparation (with added cryoprotectants) and storage is shown in Figure 4.1. 


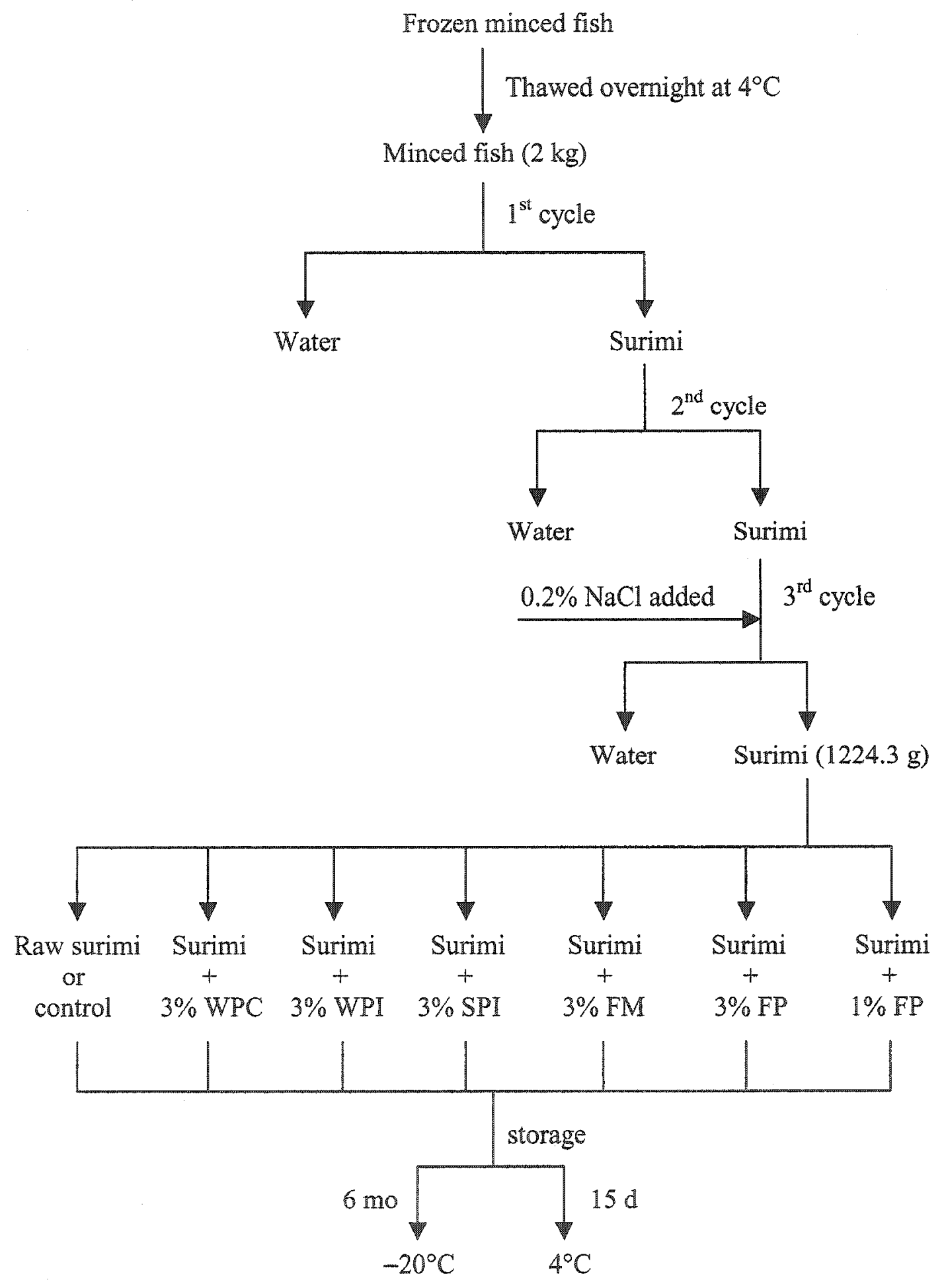

Figure 4.1: Procedure used to prepare surimi with different cryoprotectants. 


\subsubsection{Commercial Surimi Products}

To assess our surimi production method and effectiveness of our treatments, surimi prepared in the laboratory was compared to market raw surimi (H. Aida Inc., Valleyfield, QC), and three flavored Alaska pollock surimi products labeled as Atlantic lobster (referred to as lobster or LO), Atlantic scallop (referred to as scallop or SC), and King crab (referred to as crab or CR) (SeaOuest, Montreal, QC) during storage at -20 and $4^{\circ} \mathrm{C}$. In two of the flavored Alaska pollock products from the market (Atlantic lobster and Atlantic scallop) soy and whey proteins were present, and in the third product (King crab) soy and wheat proteins were present as ingredients. There was no antimicrobial preservative in these products. It is also worth mentioning that in the market, surimi is processed into various gelled products, such as lobster, scallop, and crab meat analogs, which are very popular in the U.S. and, particularly, in Japan and Korea because of their unique textural quality (Zalke, 1992).

\subsubsection{Extraction and Precipitation of Defatted Flaxseed Meal Protein}

Flaxseed proteins were extracted from defatted flaxseed meal with sodium hydroxide $(\mathrm{NaOH})$ at $\mathrm{pH} 11$ (drop-wise addition of $50 \% \mathrm{NaOH}$ to distilled water). The meal $(40 \mathrm{~g})$ was mixed with $400 \mathrm{ml}$ of the above-mentioned solvent for $1 \mathrm{~h}$ with intermittent stirring using a glass rod. The mixture was then centrifuged (Beckman Avanti $\left.^{\mathrm{TM}} \mathrm{J}-25 \mathrm{l}\right)$ at $10,000 \mathrm{RPM}(17,696 \mathrm{xg})$ for $20 \mathrm{~min}$ at $4^{\circ} \mathrm{C}$, and the supernatant was filtered using cheesecloth.

The proteins from the extract were isolated using isoelectric precipitation. The $\mathrm{pH}$ of the extract was adjusted between 4.2 and 4.6 using a dilute acid $(\mathrm{HCl}, 0.1 \mathrm{~N})$. The 
precipitated proteins were separated by centrifugation at $10,000 \mathrm{RPM}$ at $4^{\circ} \mathrm{C}$ for 15 min (Dev et al., 1986; Davidson et al., 1979; Smith et al., 1946). A schematic diagram of defatted flaxseed meal protein isolation is shown in Figure 4.2. The protein obtained was washed with distilled water, again centrifuged $\left(10,000 \mathrm{RPM}\right.$ at $4^{\circ} \mathrm{C}$ for $\left.15 \mathrm{~min}\right)$, freeze-dried, and used as an additive to raw surimi.

\subsubsection{Protein Measurement}

The protein content of each wash water was determined using the method of Lowry (1951). Bovine serum albumin (Sigma Chemicals Co., St. Louis, MO) was used as a standard.

\subsection{7. $\mathrm{pH}$ Measurement}

At time 0 and after $15 \mathrm{~d}$ storage at $4^{\circ} \mathrm{C}, \mathrm{pH}$ of minced fish and surimi was measured based on the method described by Lanier (1992) using a previously calibrated Corning $\mathrm{pH}$ meter (Model 220, Corning Glass Works, Corning, NY). Five grams of surimi was added to $50 \mathrm{ml}$ distilled water and blended thoroughly using a glass rod for $30 \mathrm{~min}$ at $4^{\circ} \mathrm{C}$ prior to the measurement of $\mathrm{pH}$. The suspensions were then filtered using cheesecloth, and the $\mathrm{pH}$ was measured.

\subsubsection{Electrophoretic Amalyses}

The procedures used to perform SDS-PAGE and native-PAGE were the same as those described in Sections 3.1.4.1 and 3.1.4.2, respectively. Gradient gels (4-20\%) were used to conduct all SDS-PAGE and native-PAGE experiments. 


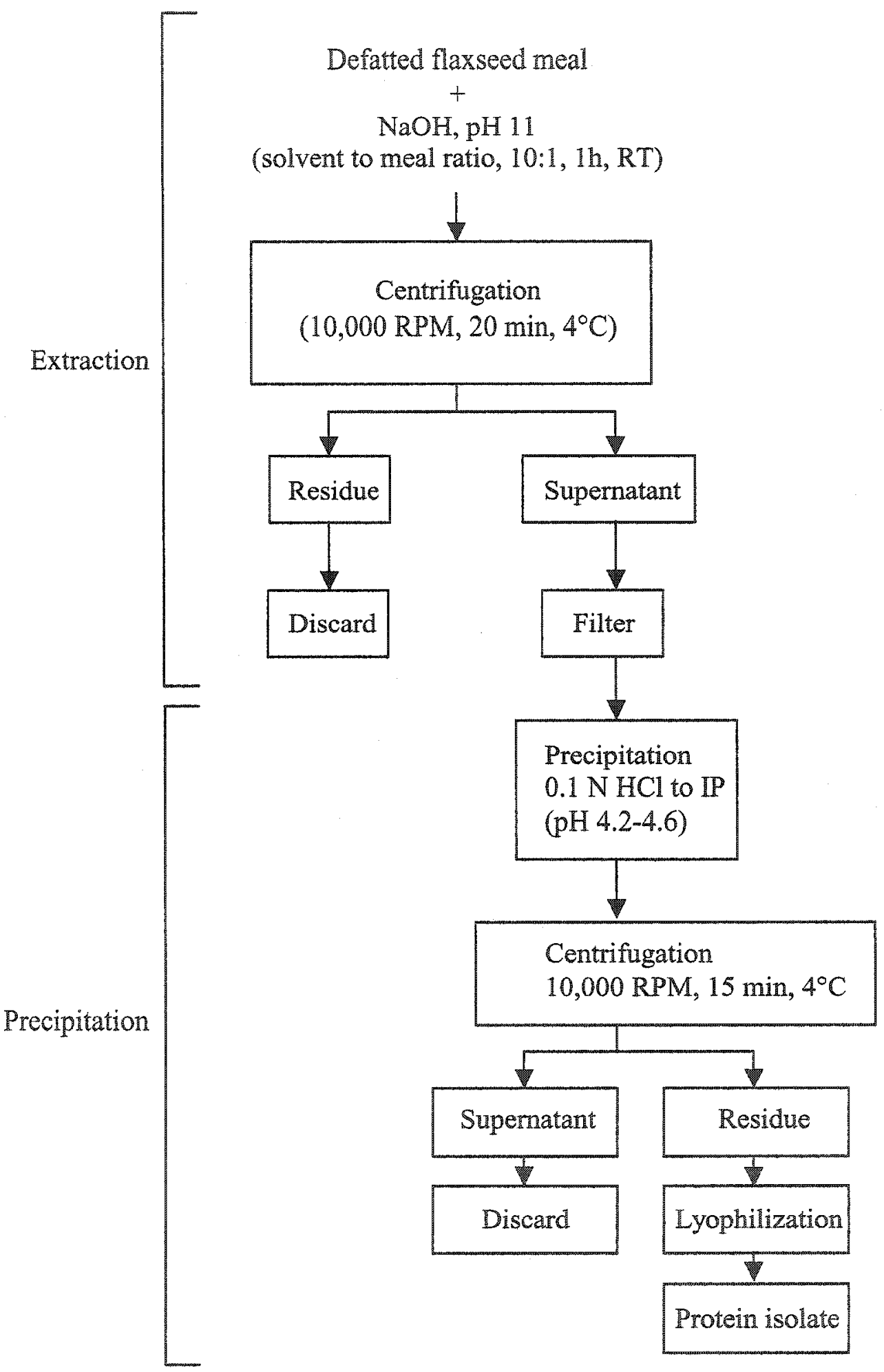

Figure 4.2: Procedure used to prepare protein isolates from defatted flaxseed meal. 


\subsubsection{FTIR/ATR Spectroscopy}

The procedure used to carry out FTIR/ATR spectroscopy analyses was the same as that described in Section 3.1.5. In this chapter integrated intensities of various components of the protein amide I band representing different protein conformations were calculated and used for data analysis, as described previously in section 3.2.4.3.

All of the experiments described under Materials and Methods section were repeated at least twice until good reproducibility was obtained. The results are averages of duplicate analysis. 


\subsection{RESULTS AND DISCUSSION}

\subsubsection{Surimi Preparation}

Table 4.1 shows some parameters measured during preparation of surimi. A total of $23.4 \mathrm{~g}$ protein was washed out from minced fish. The yield from the surimi preparation was $61.2 \%$, very close to the result of the previous chapter. Approximately 12.25 liters of wash waters was generated to prepare $1 \mathrm{~kg}$ of surimi. The protein contents of wash waters were $2.36,1.34$, and $0.66 \mathrm{mg} / \mathrm{ml}$ for the first to the third wash waters, respectively.

\subsubsection{Properties of Wash Waters}

Native-PAGE patterns of wash waters showed a decrease in band intensities for both lyophilized and liquid samples of wash waters (Figure 4.3a). In the first lyophilized sample of wash water, the band of actin and a band with MW of $\sim 13 \mathrm{kDa}$ were present. In the second wash water, in addition to those bands, two other bands with $\mathrm{MW}$ of $\sim 67$, and $\sim 18 \mathrm{kDa}$ appeared. In the third wash only major bands with $\mathrm{MW}$ of $\sim 67$ and $\sim 18 \mathrm{kDa}$ were observed.

The SDS-PAGE patterns of wash waters revealed an increase of band intensity for the lyophilized samples and decrease of band intensity for the liquid samples of wash waters (Figure $4.3 \mathrm{~b}$ ). In the case of lyophilized samples the increase in band intensities may be due to the higher purity of remaining compounds after successive washing cycles. During washing cycles mainly proteins with MW of 47 (actin), 19, and $15 \mathrm{kDa}$ were washed out from minced fish. 
Table 4.1. Parameters measured during surimi preparation

\begin{tabular}{|c|c|c|c|}
\hline & $1^{\text {st }}$ cycle & $2^{\text {nd }}$ cycle & $3^{\text {rd }}$ cycle \\
\hline Weight of fish or surimi $(\mathrm{kg})$ & 2 & 1.32 & 1.566 \\
\hline Volume of water added (1) & 6 & 3.96 & 4.7 \\
\hline Weight of final suimi $(\mathrm{kg})$ & 1.38 & 1.626 & 1.224 \\
\hline $\begin{array}{c}\text { Vol. of wash water at the end of } \\
\text { each cycle (1) }\end{array}$ & 6.53 & 3.53 & 4.94 \\
\hline $\begin{array}{c}\text { Protein content mg/ml } \\
\text { Protein removed (g) }\end{array}$ & 2.36 & 1.34 & 0.66 \\
\hline$\%$ Of total protein removed & 65.85 & 20.21 & 13.93 \\
\hline
\end{tabular}

${ }^{1}$ Total protein removed after three washing cycles $=23.4 \mathrm{~g}$

Yield of surimi preparation from minced fish $=61.2 \%$ 


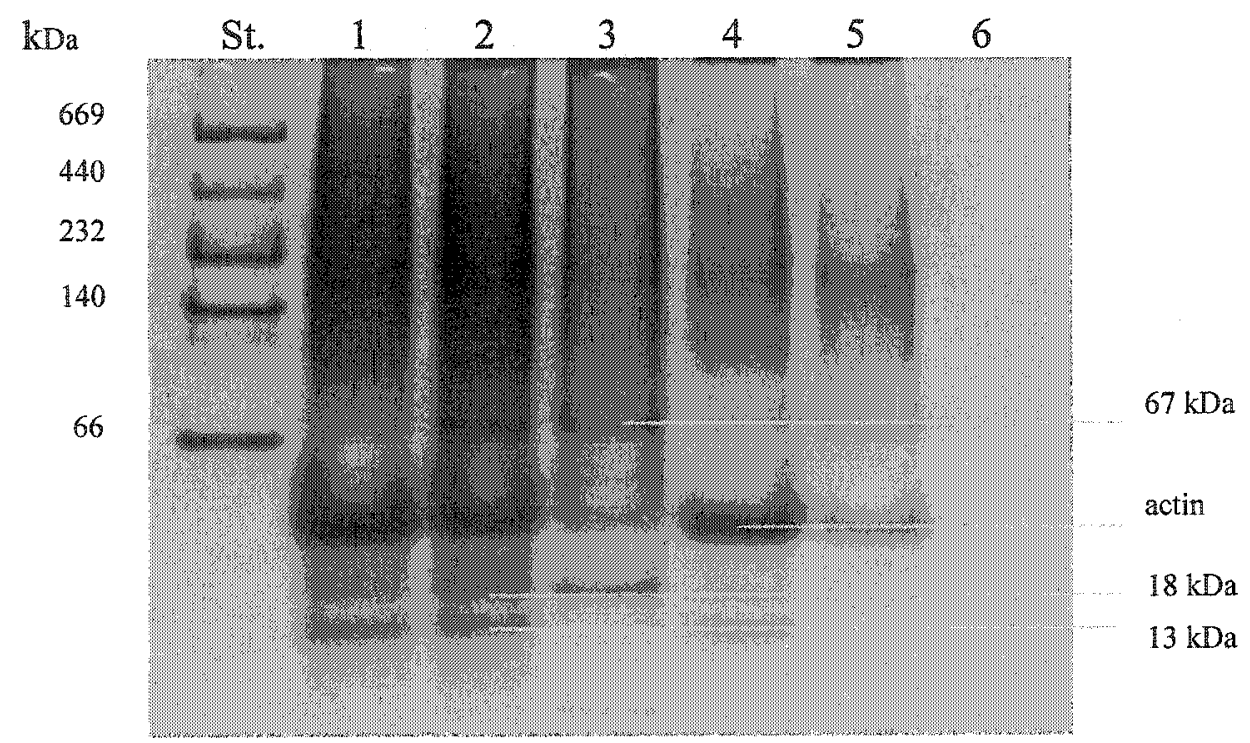

(a)

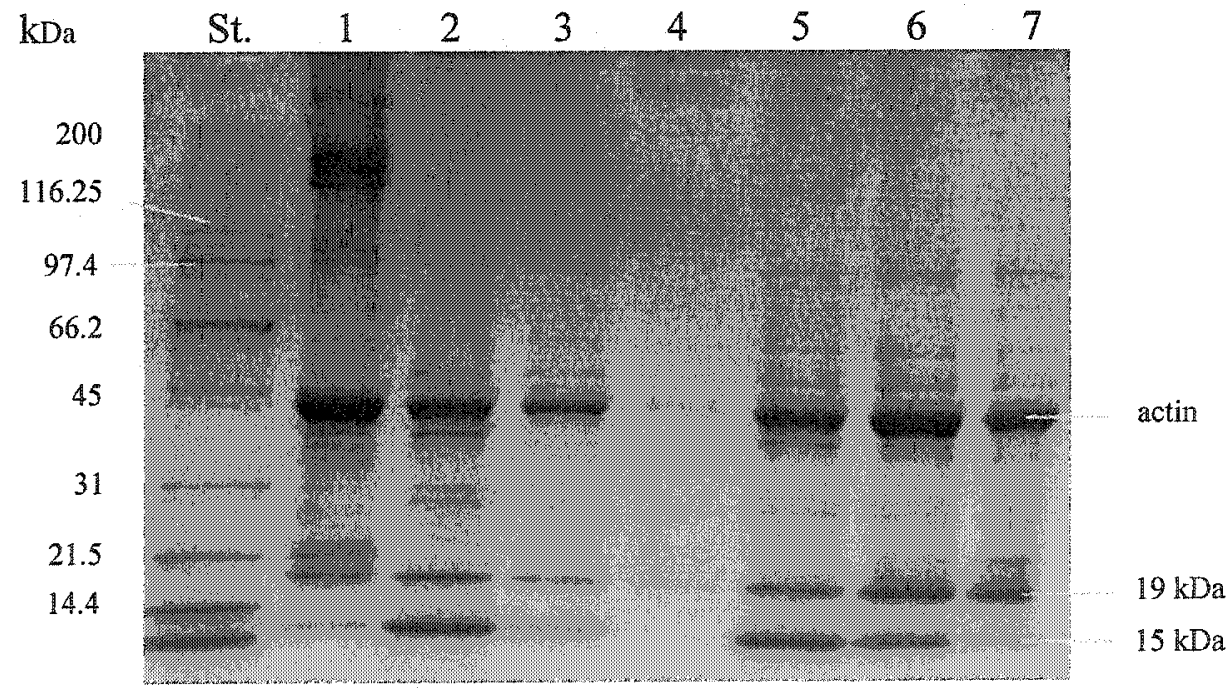

(b)

Figure 4.3: Electrophoretic patterns of wash waters: (a) native-PAGE, St. high molecular weight (HMW) standard; 1-3 lyophilized samples of $1^{\text {st }}$ to $3^{\text {rd }}$ wash waters; 4-6 liquid samples of $1^{\text {st }}$ to $3^{\text {rd }}$ wash waters; (b) SDS-PAGE, St. broad range molecular weight standard; 1 minced fish; 2-4 liquid samples of $1^{\text {st }}$ to $3^{\text {rd }}$ wash waters; 5-7 lyophilized samples of $1^{\text {st }}$ to $3^{\text {rd }}$ wash waters. 
Both native and SDS-PAGE patterns of wash waters support the results from the previous chapter indicating removal of myofibrillar proteins, particularly actin, during successive washing cycles. These findings also support the study by Stefansson and Hultin (1994) that showed cod muscle myofibrillar proteins were soluble in water at neutral $\mathrm{pH}$. This solubility was sensitive to ionic strength and was reversible.

Figure 4.4 represents deconvolved FTIR/ATR spectra of lyophilized samples of wash waters. The results reveal removal of different compounds in the $1^{\text {st }}$ and $2^{\text {nd }}$ wash waters, however, the spectra of the $3^{\text {rd }}$ wash water shows the presence of mainly protein bands. There was an increase in both $\alpha$-helix and $\beta$-sheet structure contents. Since the increase was higher for $\beta$-sheet structure, the ratio of $\alpha$-helix to $\beta$-sheet contents decreased by successive washing steps.

\subsubsection{Electrophoresis Analyses on Cryoprotectants}

Shown in Figure $4.5 \mathrm{a}$ are the native-PAGE patterns of the cryoprotectants used in this study. The approximate molecular weights of major bands in each additive were estimated using high molecular weight (HMW) standards. Three main bands were observed in whey protein concentrate (WPC) with MW of 51,32 , and $10 \mathrm{kDa}$. Whey

protein isolate (WPI) showed four major bands with MW of $66,34,22$, and $17 \mathrm{kDa}$. In soy protein isolate (SPI), also four main bands with MW of $565,485,321$, and 224 $\mathrm{kDa}$ were revealed. Sathe (1991) reported that soy protein contains two major proteins with a MW of $350 \mathrm{kDa}$ for glycinin and $180 \mathrm{kDa}$ for $\beta$-conglycinin. Finally, in both flaxseed protein (FP) and flaxseed meal (FM) one major band with MW of $305 \mathrm{kDa}$ appeared. In flaxseed meal there was also another faint band with $\mathrm{MW}$ of $485 \mathrm{kDa}$. 

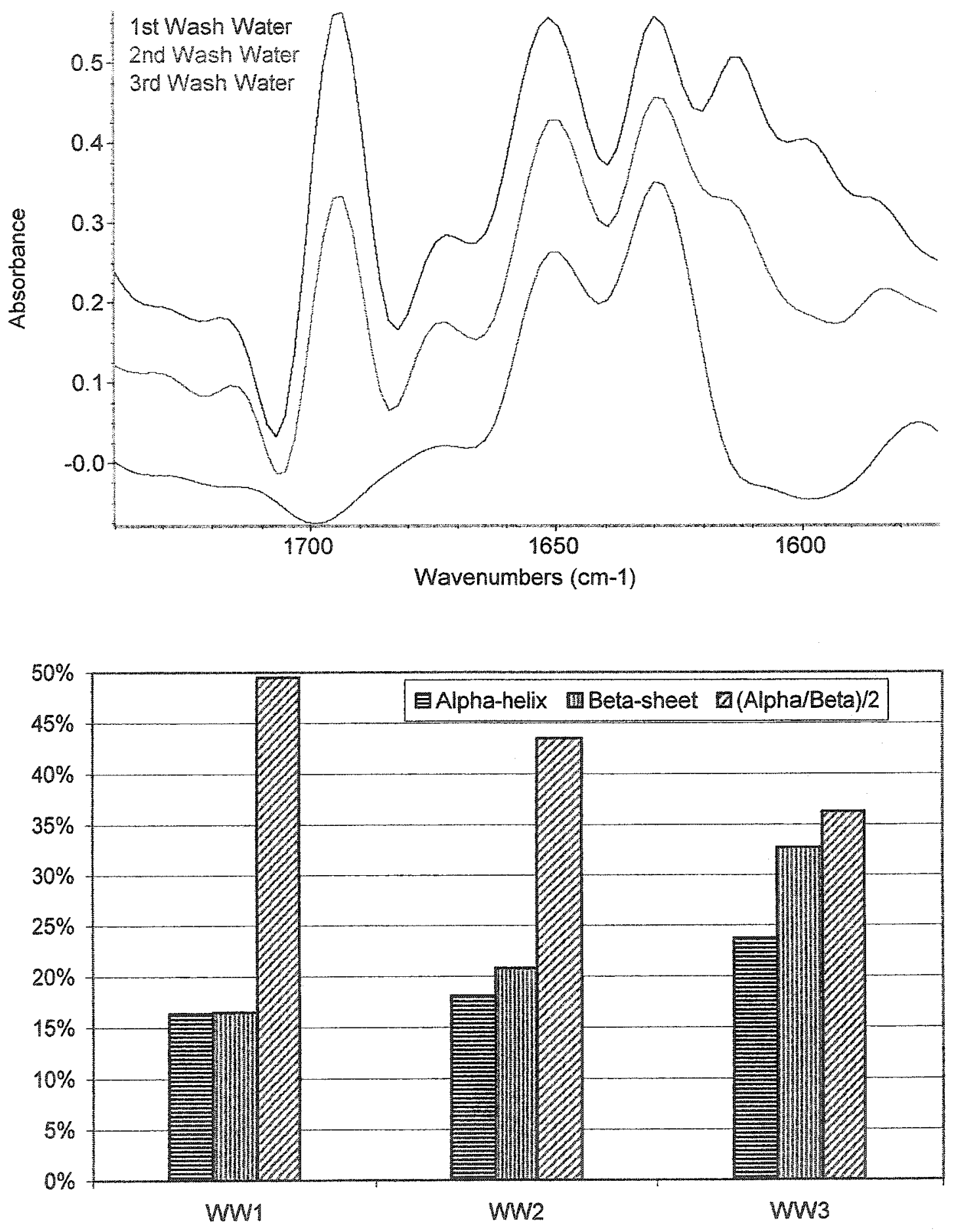

Figure 4.4: Stacked plot of deconvolved FTIR/ATR spectra of lyophilized samples of wash waters (top); percentage of $\alpha$-helix, $\beta$-sheet structures and their ratio (bottom). The spectra have been offset for clarity. 


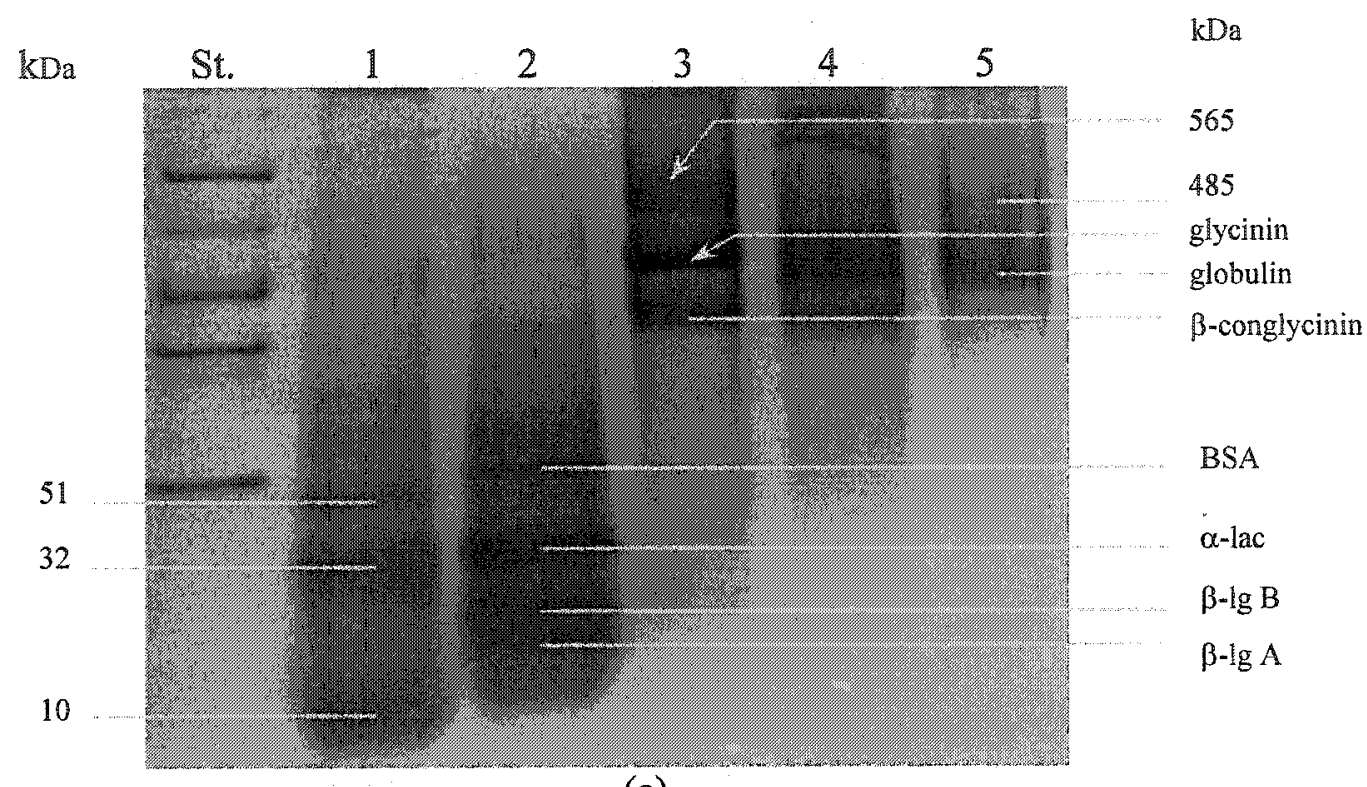

(a)

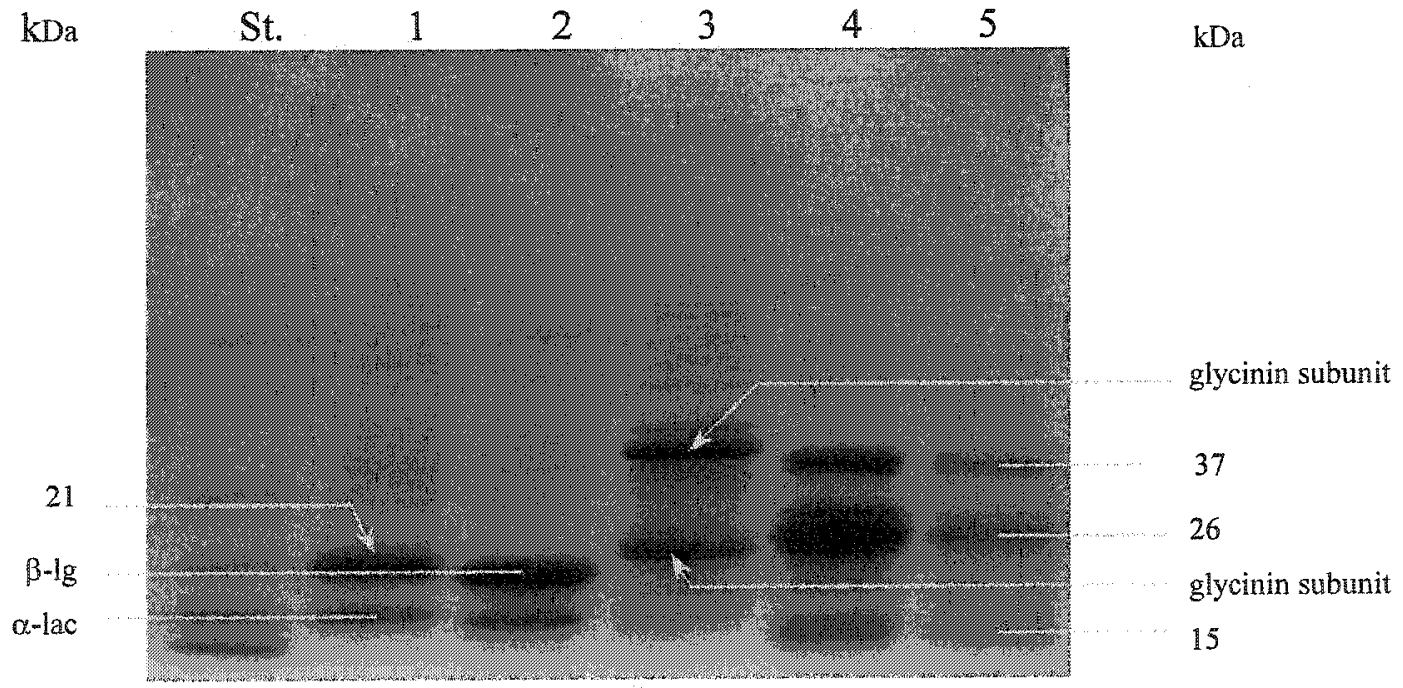

(b)

Figure 4.5: Electrophoretic patterns of individual cryoprotectants: (a) native-PAGE, St. high molecular weight (HMW) standard; 1 whey protein concentrate (WPC); 2 whey protein isolate (WPI); 3 soy protein isolate (SPI); 4 flaxseed protein (FP); 5 flaxseed meal (FM); (b) SDS-PAGE, St. broad range molecular weight standard; 1 WPC; 2 WPI; 3 SPI; 4 FP; 5 FM. 
Sammour (1994) reported that flaxseed contains a major globular protein with MW of approximately $320 \mathrm{kDa}+/-20$ by gel filtration. Albumins (soluble in water) and globulins (insoluble in water) are the storage proteins of flaxseed (Oomah and Mazza, 1993).

The SDS-PAGE patterns of the cryoprotectants on 4-20\% gradient gel (Figure 4.5b) revealed the presence of two major bands for each of WPI, WPC, and SPI with MW of 21,$16 ; 20,16$; and $40,23 \mathrm{kDa}$, respectively. WPC consists of several protein components (Boye, 1995; Morr, 1992): $\beta$-lactoglobulin, $\alpha$-lactalbumin, serum albumin, and immunoglobulin. In both flaxseed meal and flaxseed protein three major bands with MW of 37,26 , and $15 \mathrm{kDa}$ were observed. Madhusudhan and Singh (1985a) reported that flaxseed protein has five subunits with $\mathrm{MW}$ of $11,18,29,42$, and $61 \mathrm{kDa}$. On reducing SDS-PAGE (with 2-mercaptoethanol), the major polypeptides cleaved into acidic subunits with MW of 40 and $25 \mathrm{kDa}$ and basic subunits with MW of 22 and $18 \mathrm{kDa}$ (Sammour, 1994). SDS-PAGE showed that albumin consists of a single polypeptide chain with MW between 15 to $17 \mathrm{kDa}$ (Madhusudhan and Singh, 1985b).

\subsubsection{Changes During Storage of Surimi}

Storage of surimi was done at $4^{\circ} \mathrm{C}$ and at $-20^{\circ} \mathrm{C}$. Storage at $4^{\circ} \mathrm{C}$ is not used for commercial surimi; however, it provided us a means to observe protein changes in a relatively short time period, compared with storage at $-20^{\circ} \mathrm{C}$. 


\subsubsection{1. $\mathrm{pH}$}

Figure 4.6 shows the $\mathrm{pH}$ of all samples of minced fish and surimi as well as the market products after $15 \mathrm{~d}$ storage at $4^{\circ} \mathrm{C}$. It is observed that the $\mathrm{pH}$ of minced fish and laboratory-prepared surimi samples increased during the storage; it is possibly due to the production of amines and other basic products. However, the pH of all flavored Alaska pollock products and market raw surimi dropped indicating production of acids, which may be attributed to the utilization of sugars (present in these products as an ingredient) by microorganisms. Nevertheless, based on organoleptic observations there was no indication of microbial spoilage after $10 \mathrm{~d}$ storage at $4^{\circ} \mathrm{C}$.

The drop in $\mathrm{pH}$ of all flavored Alaska pollock products and market raw surimi is in agreement with the findings of Lyver et al. (1998a, b), who reported a decrease in $\mathrm{pH}$ value of raw surimi nuggets stored at $4^{\circ} \mathrm{C}$ from 6.5 to $\sim 4.9-4.0$ in 21 days. These changes were mainly attributed to the growth of lactic acid bacteria. The microbial shelf life of raw surimi nuggets was approximately 7 to 14 days when stored at $4^{\circ} \mathrm{C}$.

It is noted here that no $\mathrm{pH}$ measurements were conducted on samples stored at $-20^{\circ} \mathrm{C}$. This is due to the fact that the main purpose of $\mathrm{pH}$ measurement was to support the notion of microbial spoilage during higher temperature storage (at $4^{\circ} \mathrm{C}$ ). Since it is known that freezing at $-20^{\circ} \mathrm{C}$ greatly inhibits microbial growth; therefore, there would be no reason for such measurement during low temperature storage. 


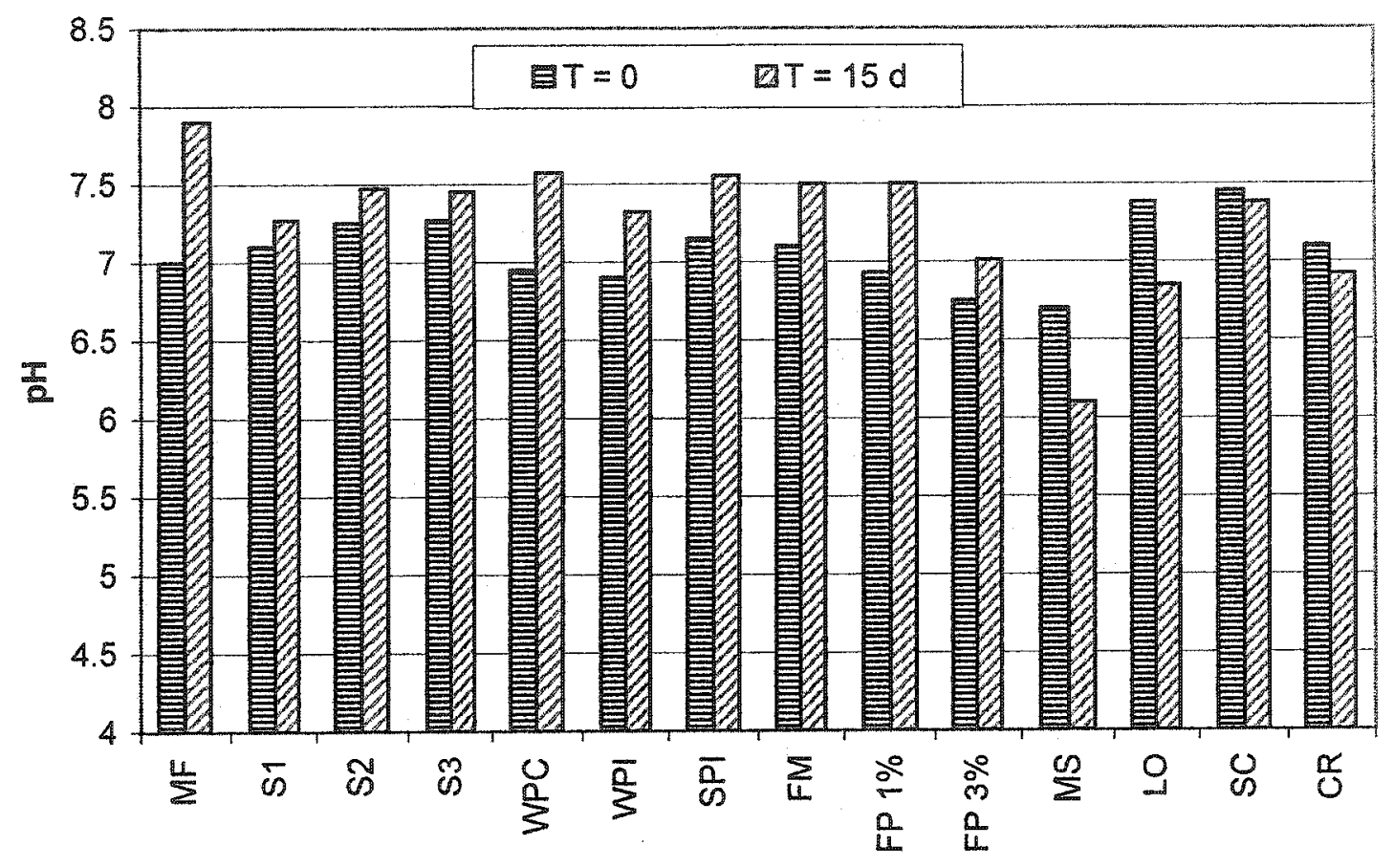

Figure 4.6: $\mathrm{pH}$ of different products at $t=0$ and after $15 \mathrm{~d}$ storage at $4^{\circ} \mathrm{C}$; $\mathrm{MF}$ minced fish, S1 surimi $1^{\text {st }}, \mathrm{S} 2$ surimi $2^{\text {nd }}, \mathrm{S} 3$ surimi $3^{\text {rd }}$, WPC surimi with whey protein concentrate, WPI surimi with whey protein isolate, SPI surimi with soy protein isolate, FM surimi with flaxseed meal, FP $1 \%$ surimi with $1 \%$ flaxseed protein, FP 3\% surimi with $3 \%$ flaxseed protein, MS market surimi, LO lobster-flavored surimi, SC scallopflavored surimi, CR crab-flavored surimi. 


\subsubsection{Electrophoretic Analyses}

\subsection{Native-PAGE}

Shown in Figure 4.7a are the results of native-PAGE at time 0; it reveals the presence of six and four major bands in minced fish and surimi, respectively, as indicated also in the previous chapter, section 3.2.4.1. (Figure 3.7). During preparation of surimi, the disappearance of the actin band was accompanied by the appearance of the bands in the range of $\sim 100$ to $~ 300 \mathrm{kDa}$. These observations confirm the findings in the previous chapter.

Market raw surimi has similar electrophoretic pattern as laboratory-made raw surimi with the major band of $\sim 76 \mathrm{kDa}$. The three flavored Alaska pollock surimi (crab, scallop, and lobster) showed faint bands possibly due to higher amounts of other additives. These products also had similar electrophoretic patterns as market raw surimi and laboratory-made raw surimi. Figure $4.7 \mathrm{~b}$ shows the electropherograms of minced fish, raw surimi, and surimi with different cryoprotectants.

The native-PAGE results shown in Figures 4.8 revealed no major changes in minced fish, surimi (either made in the laboratory or from market), or surimi with added SPI after 6 months of storage at $-20^{\circ} \mathrm{C}$. However, fading of the bands attributed to WPC, WPI, FM, and FP was observed in surimi with these cryoprotectants.

Figures $4.9 \mathrm{a}$ and $\mathrm{b}$ revealed the appearance of an additional band with $\mathrm{MW}$ of $\sim 23 \mathrm{kDa}$ for all samples after $5 \mathrm{~d}$ storage at $4^{\circ} \mathrm{C}$. This band was present at time 0 as a shade and not as a separate distinct band. In surimi with added SPI also fading of the major band of soy protein with $M W$ of $\sim 321 \mathrm{kDa}$ was observed. After $10 \mathrm{~d}$ storage at $4^{\circ} \mathrm{C}$, fading of several bands occurred (Figures $4.10 \mathrm{a}$ and $\mathrm{b}$ ). 


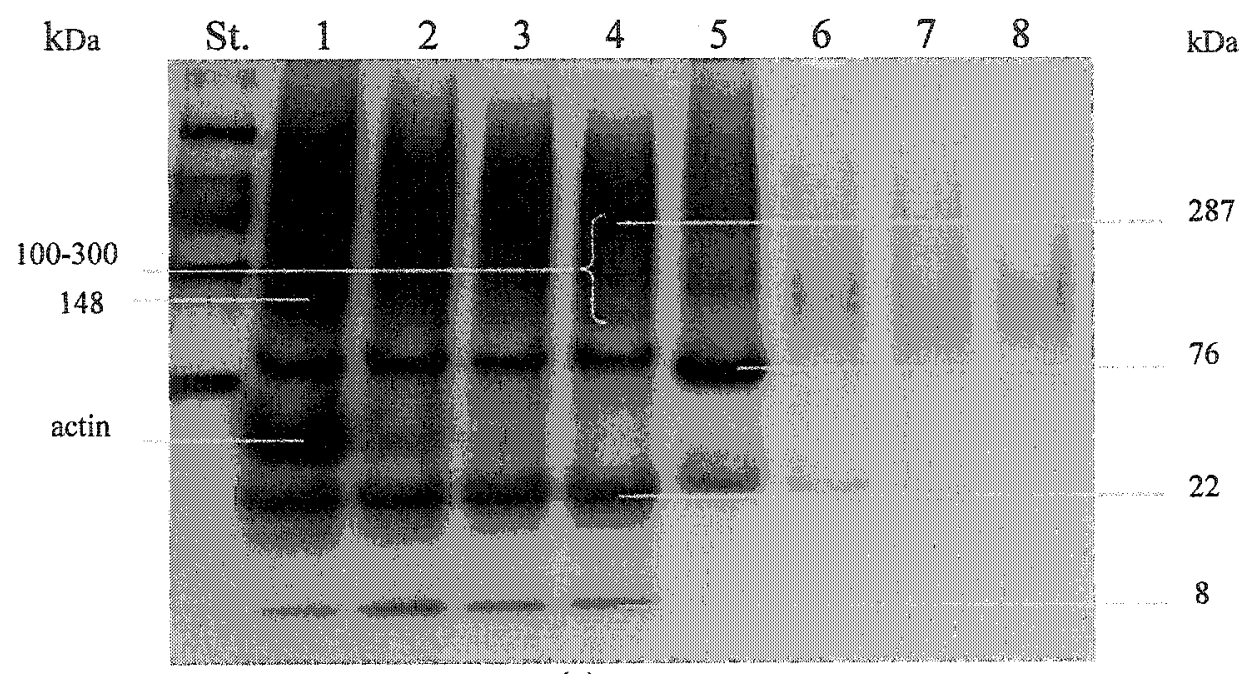

(a)

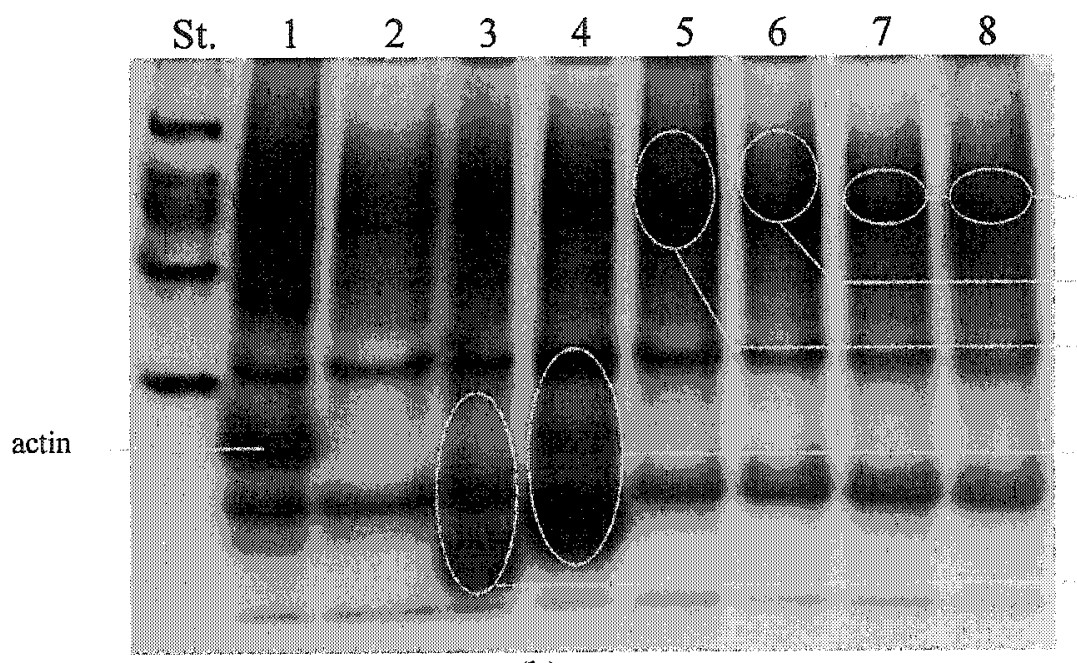

flaxseed protein

flaxseed meal

soy protein isolate

whey protein isolate

whey protein concentrate

(b)

Tigure 4.7: Native-PAGE patterns of minced fish and surimi at time 0: (a) St.

HMW standard; 1 minced fish; 2 surimi $1^{\text {st }} ; 3$ surimi $2^{\text {nd }} ; 4$ surimi $3^{\text {rd }} ; 5$ market surimi; 6 LO; 7 SC; 8 CR; (b) St. HMW standard; 1 minced fish; 2 surimi $3^{\text {rd }} ; 3$ surimi with WPC; 4 surimi with WPI; 5 surimi with SPI; 6 surimi with $\mathrm{FM} ; 7$ surimi with $1 \% \mathrm{FP} ; 8$ surimi with $3 \% \mathrm{FP}$ (for abbreviations refer to Figure 4.6). 


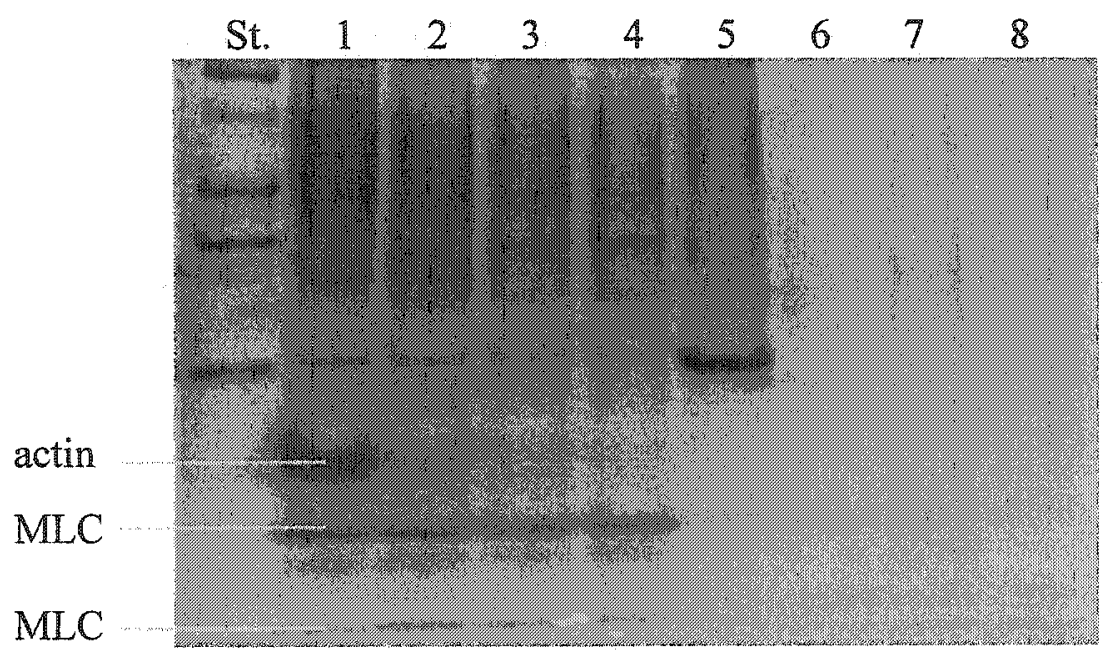

(a)

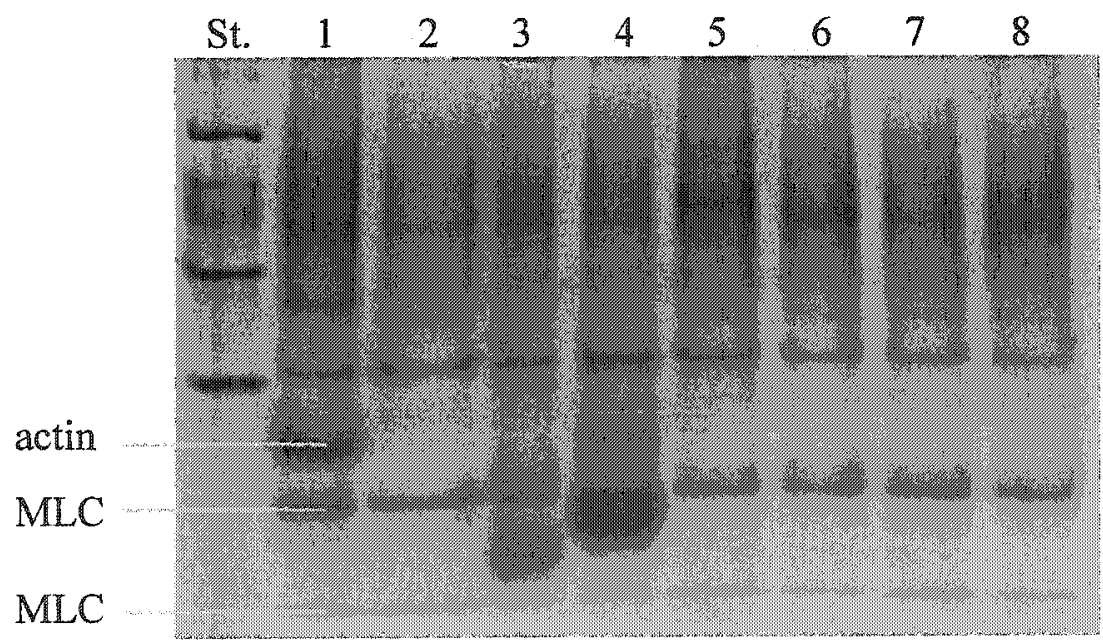

(b)

Figure 4.8: Native-PAGE patterns of minced fish and surimi after 6 mo storage at $-20^{\circ} \mathrm{C}$ : (a) St. HMW standard; 1 minced fish; 2 surimi $1^{\text {st }} ; 3$ surimi $2^{\text {nd }} ; 4$ surimi $3^{\text {rd }} ; 5$ market surimi; $6 \mathrm{LO} ; 7 \mathrm{SC} ; 8 \mathrm{CR}$; (b) St. HMW standard; 1 minced fish; 2 surimi $3^{\text {rd }} ; 3$ surimi with WPC; 4 surimi with WPI; 5 surimi with SPI; 6 surimi with FM; 7 surimi with $1 \% \mathrm{FP} ; 8$ surimi with $3 \% \mathrm{FP}$ (for abbreviations refer to Figure 4.6 ). 


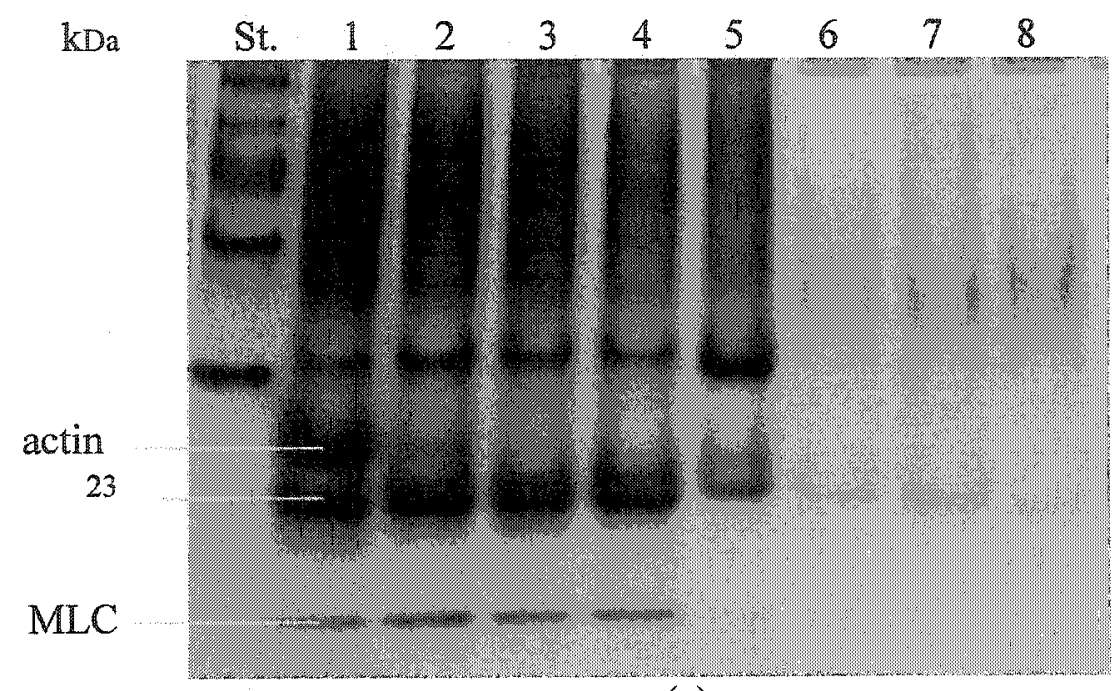

(a)

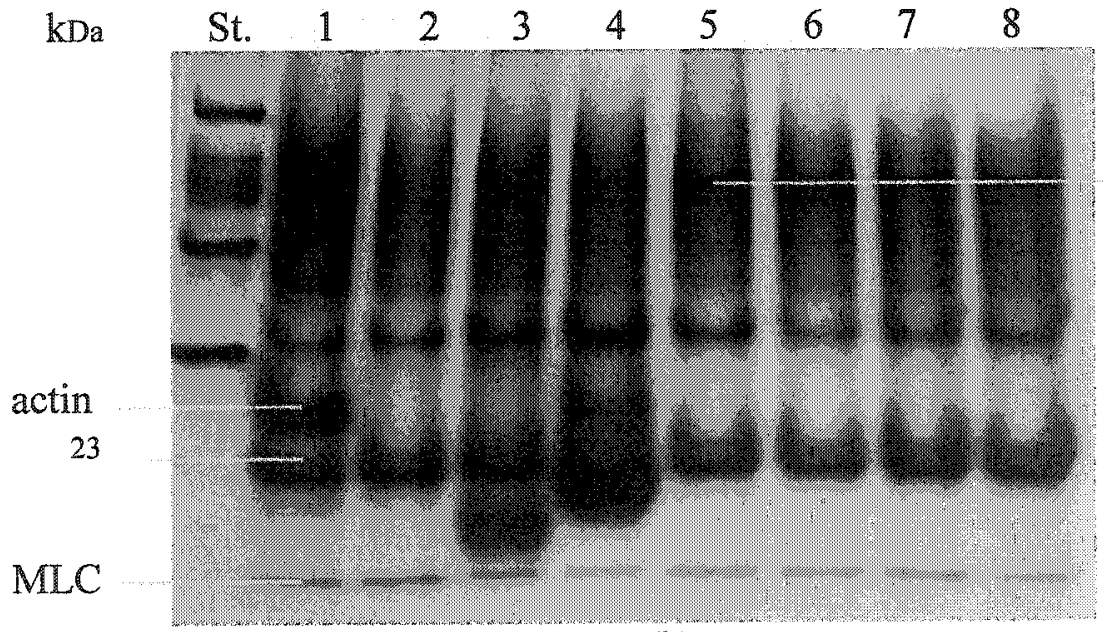

$\mathrm{kDa}$

(b)

Figure 4.9: Native-PAGE patterns of minced fish and surimi after $5 \mathrm{~d}$ storage at $4^{\circ} \mathrm{C}$ : (a) St. HMW standard; 1 minced fish; 2 surimi $1^{\text {st. }} ; 3$ surimi $2^{\text {nd }} ; 4$ surimi $3^{\text {rd }} ; 5$ market surimi; $6 \mathrm{LO} ; 7 \mathrm{SC} ; 8 \mathrm{CR}$; (b) St. HMW standard; 1 minced fish; 2 surimi $3^{\text {rd }} ; 3$ surimi with WPC; 4 surimi with WPI; 5 surimi with SPI; 6 surimi with FM; 7 surimi with $1 \%$ FP; 8 surimi with $3 \%$ FP (for abbreviations refer to Figure 4.6). 


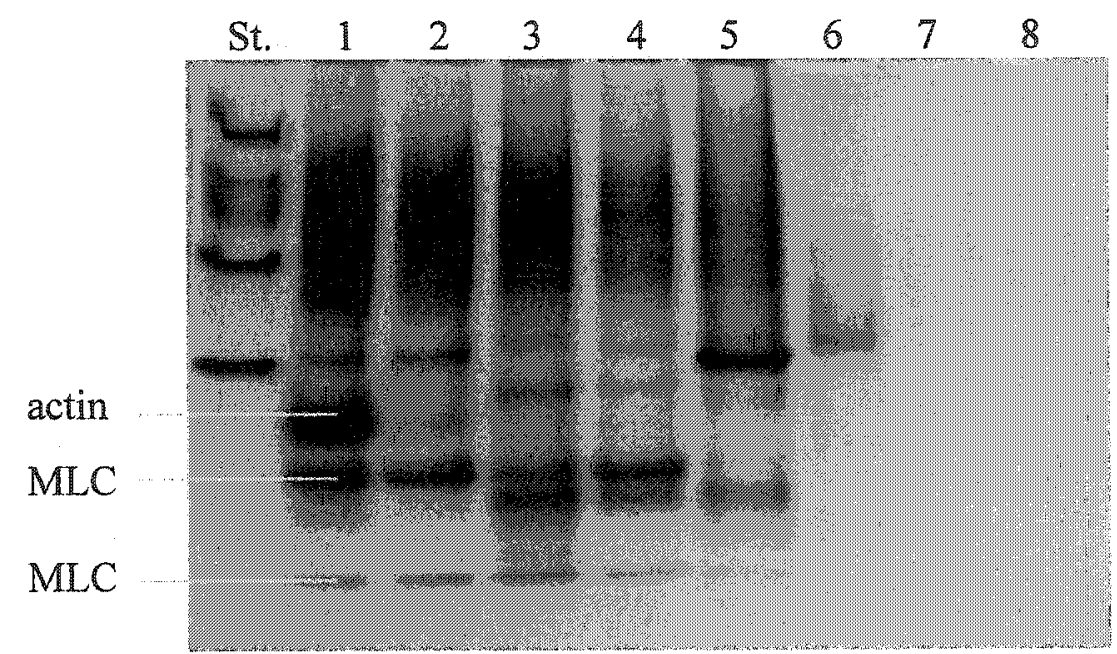

(a)

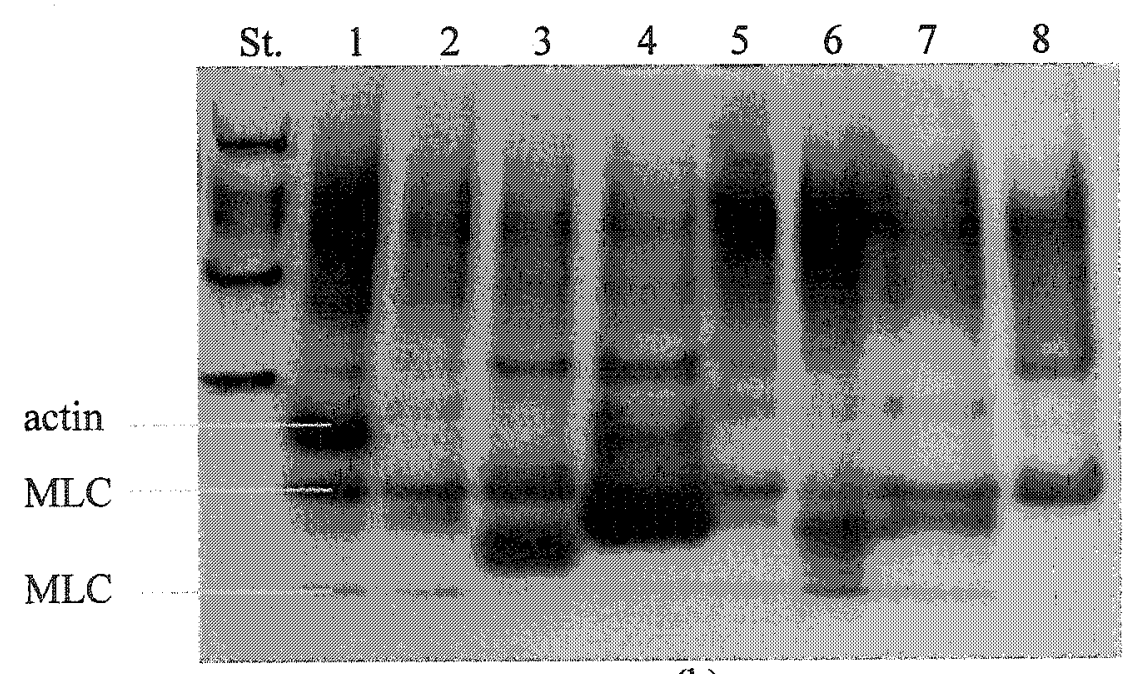

(b)

Figure 4.10: Native-PAGE patterns of minced fish and surimi after $10 \mathrm{~d}$ storage at $4^{\circ} \mathrm{C}$ : (a) St. HMW standard; 1 minced fish; 2 surimi $1^{\text {st }} ; 3$ surimi $2^{\text {nd }} ; 4$ surimi $3^{\text {rd }} ; 5$ market surimi; $6 \mathrm{LO} ; 7 \mathrm{SC} ; 8 \mathrm{CR}$; (b) St. HMW standard; 1 minced fish; 2 surimi $3^{\text {rd }} ; 3$ surimi with WPC; 4 surimi with WPI; 5 surimi with SPI; 6 surimi with FM; 7 surimi with $1 \%$ FP; 8 surimi with $3 \% \mathrm{FP}$ (for abbreviations refer to Figure 4.6). 
Native-PAGE revealed substantial changes for most of the samples after $15 \mathrm{~d}$ storage at $4^{\circ} \mathrm{C}$ (Figures $4.11 \mathrm{a}$ and $\mathrm{b}$ ). The six major bands were still present but faded in minced fish. In raw surimi fading of all major bands occurred, especially the bands with MW of $\sim 76$ and $\sim 22 \mathrm{kDa}$. Fading of these two bands was also observed for surimi with added WPC. In surimi with added WPI a band appeared with MW of $\sim 52 \mathrm{kDa}$. Only bands with $\mathrm{MW}$ of $290,25,20$, and $11 \mathrm{kDa}$ were present in surimi with added SPI. In surimi with added flaxseed meal there was just one band with MW of $11 \mathrm{kDa}$. In surimi with $3 \%$ flaxseed protein faded bands with MW of $290,52,26$, and $11 \mathrm{kDa}$ were present. In surimi with $1 \%$ flaxseed protein another band with $\mathrm{MW}$ of $21 \mathrm{kDa}$ was observed.

\subsection{SDS-PAGE}

The SDS-PAGE patterns of minced fish, market products, and surimi with different cryoprotectants are shown in Figure $4.12 \mathrm{a}$ and $\mathrm{b}$. The major bands in minced fish and lab-made raw surimi were the same as described in the previous chapter.

The SDS-PAGE patterns of minced fish and raw surimi showed no substantial changes after 6 mo storage at $-20^{\circ} \mathrm{C}$ (Figure 4.13a). Fading of one of the MLC bands with $\mathrm{MW}$ of $23 \mathrm{kDa}$, and one band under MHC with MW of $136 \mathrm{kDa}$ were observed in all samples shown in Figure 4.13 b. 


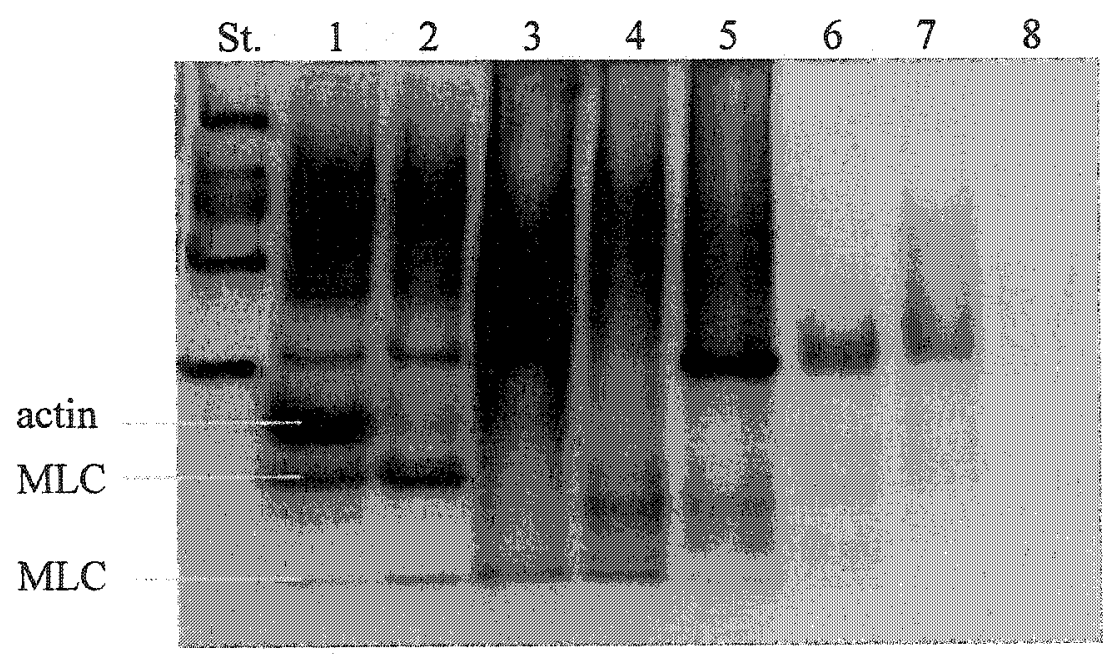

(a)

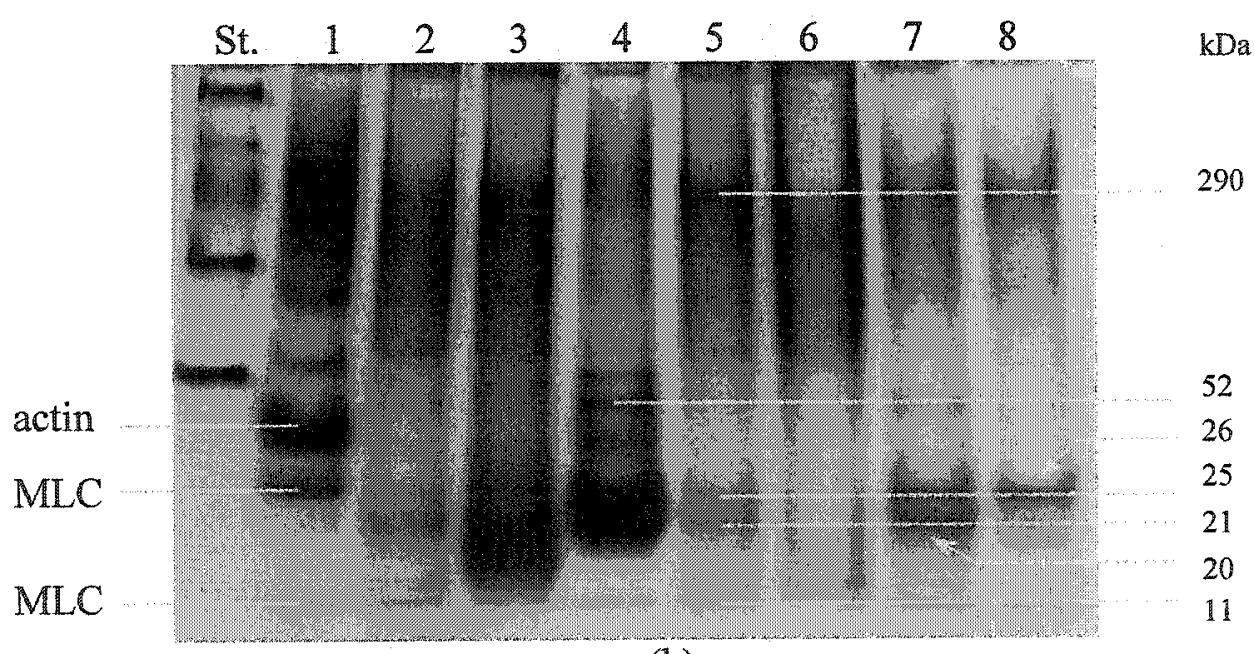

(b)

Wigure 4.11: Native-PAGE patterns of minced fish and surimi after $15 \mathrm{~d}$ storage at $4^{\circ} \mathrm{C}$ : (a) St. HMW standard; 1 minced fish; 2 surimi $1^{\text {st }} ; 3$ surimi $2^{\text {nd }} ; 4$ surimi $3^{\text {rd }} ; 5$ market surimi; $6 \mathrm{LO} ; 7 \mathrm{SC} ; 8 \mathrm{CR}$; (b) St. HMW standard; 1 minced fish; 2 surimi $3^{\text {rd }} ; 3$ surimi with WPC; 4 surimi with WPI; 5 surimi with SPI; 6 surimi with FM; 7 surimi with 1\% FP; 8 surimi with $3 \% \mathrm{FP}$ (for abbreviations refer to Figure 4.6 ). 


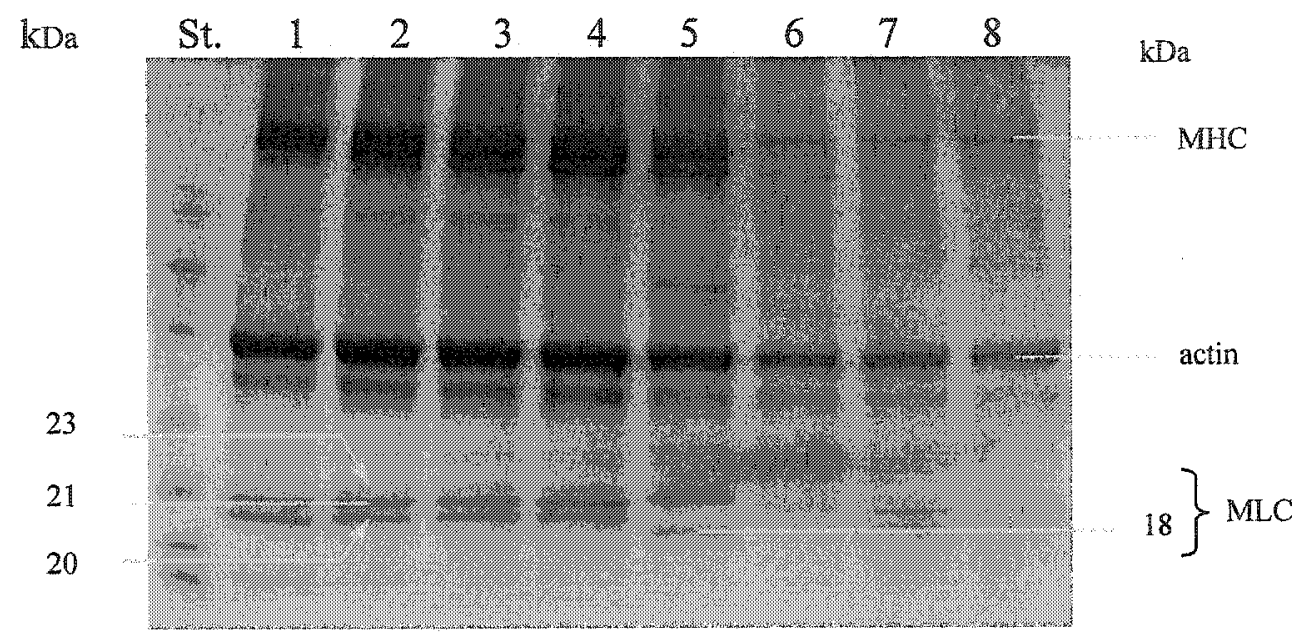

(a)

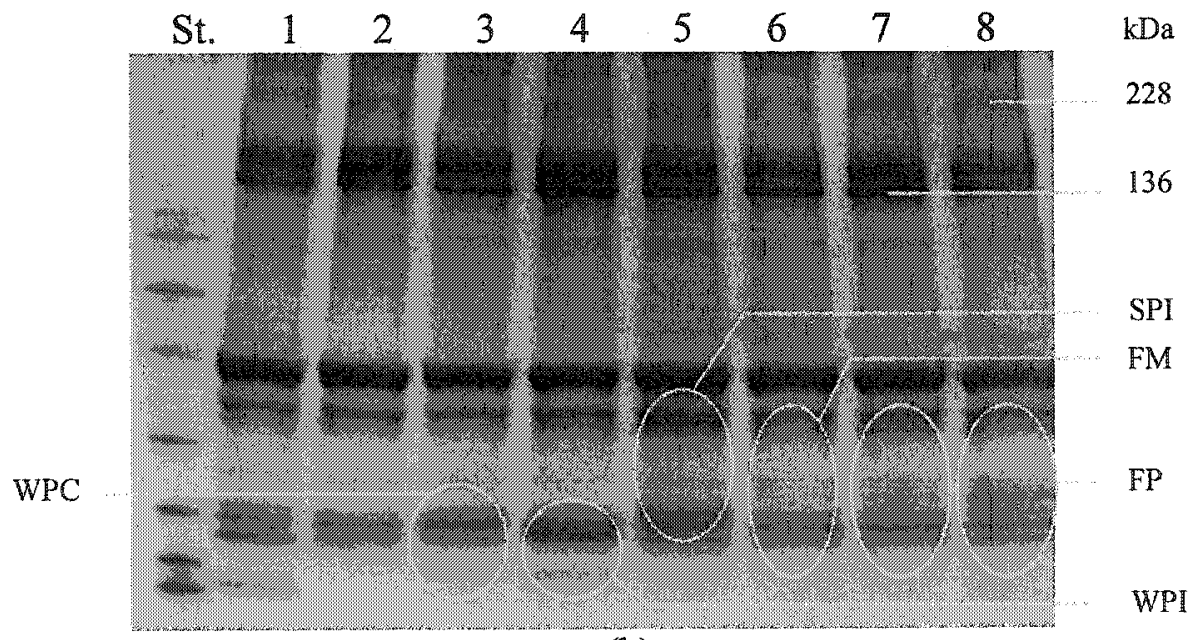

(b)

Figure 4.12: SDS-PAGE patterns of minced fish and surimi at time 0: (a) St. broad range molecular weight standard; 1 minced fish; 2 surimi $1^{\text {st }} ; 3$ surimi $2^{\text {nd }} ; 4$ surimi $3^{\text {rd }} ; 5$ market surimi; $6 \mathrm{LO} ; 7 \mathrm{SC} ; 8 \mathrm{CR}$; (b) St. broad range molecular weight standard; 1 minced fish; 2 surimi $3^{\text {rd }} ; 3$ surimi with WPC; 4 surimi with WPI; 5 surimi with SPI; 6 surimi with $\mathrm{FM} ; 7$ surimi with $1 \% \mathrm{FP} ; 8$ surimi with $3 \% \mathrm{FP}$ (for abbreviations refer to Figure 4.6). 


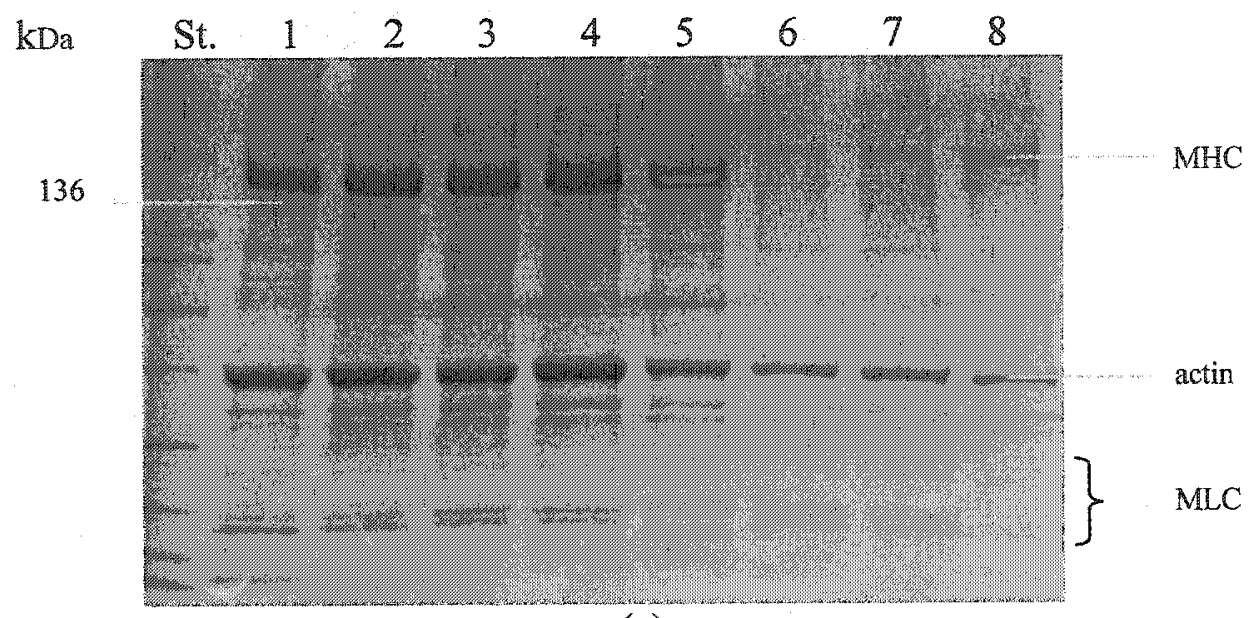

(a)

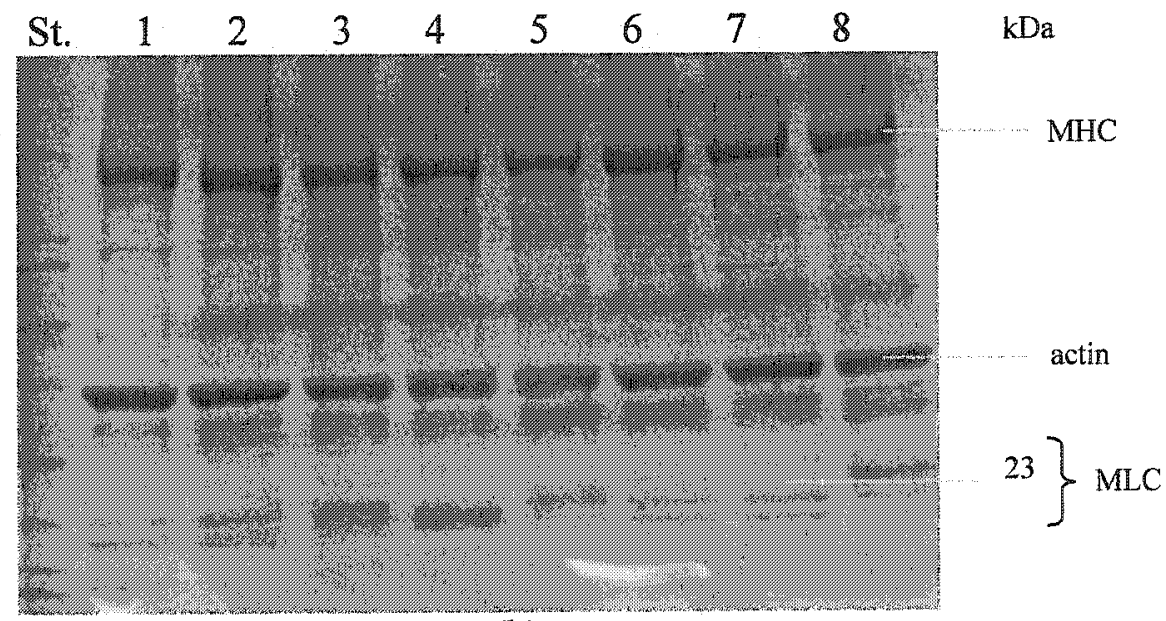

(b)

Figure 4.13: SDS-PAGE patterns of minced fish and surimi after 6 mo storage at $-20^{\circ} \mathrm{C}$ : (a) St. broad range molecular weight standard; 1 minced fish; 2 surimi $1^{\text {st }} ; 3$ surimi $2^{\text {nd }} ; 4$ surimi $3^{\text {rd }} ; 5$ market surimi; $6 \mathrm{LO} ; 7 \mathrm{SC} ; 8 \mathrm{CR}$; (b) St. broad range molecular weight standard; 1 minced fish; 2 surimi $3^{\text {rd }} ; 3$ surimi with WPC; 4 surimi with WPI; 5 surimi with SPI; 6 surimi with FM; 7 surimi with $1 \% \mathrm{FP} ; 8$ surimi with $3 \% \mathrm{FP}$ (for abbreviations refer to Figure 4.6). 
Surimi can be kept frozen at $-20^{\circ} \mathrm{C}$ for up to 6 mo without any deleterious consequences (Venugopal and Shahidi, 1995). In the study by Sultanbawa and Li-Chan (1998), the MHC band disappeared in the SDS-PAGE profile of ling cod surimi containing no added cryoprotectants at 4 months of frozen storage at $-18^{\circ} \mathrm{C}$, while the actin band was still strong.

SDS-PAGE indicates that no major change occurred after $5 \mathrm{~d}$ storage at $4^{\circ} \mathrm{C}$ (Figure $4.14 \mathrm{a}$ and $\mathrm{b}$ ). Only fading of a band above MHC with MW of $228 \mathrm{kDa}$ was observed. The three flavoured Alaska pollock surimi samples did not exhibit this band from the beginning.

Figure $4.15 \mathrm{a}$ indicates that after $10 \mathrm{~d}$ storage at $4^{\circ} \mathrm{C}$, no significant changes occurred in minced fish, surimi $1^{\text {st }}, 2^{\text {nd }}$, and $3^{\text {rd }}$. In market raw surimi, disappearance of two MLC bands with MW of 23, and $21 \mathrm{kDa}$ occurred. Furthermore, there was a major loss in MHC intensity. In market raw surimi also a band above MHC with MW of 228 $\mathrm{kDa}$ disappeared, and instead a new band with $\mathrm{MW}$ of $134 \mathrm{kDa}$ was observed under MHC. In the case of the three flavored Alaska pollock products, fading of MHC occurred. Figure $4.15 \mathrm{~b}$ shows no major changes except fading of the bands with MW of 228 , and $136 \mathrm{kDa}$.

Figure $4.16 \mathrm{a}$ reveals that after $15 \mathrm{~d}$ storage at $4^{\circ} \mathrm{C}$ minced fish was relatively stable. Fading of MHC and disappearance of a band with $\mathrm{MW}$ of $228 \mathrm{kDa}$ occurred in surimi $1^{\text {st }}$, while in surimi $2^{\text {nd }}$ these two bands completely disappeared, and instead several new bands appeared in the range of 56 to $84 \mathrm{kDa}$. Furthermore, two bands of MLC with MW of 23 and $21 \mathrm{kDa}$ disappeared and another MLC with MW of $20 \mathrm{kDa}$ faded. In surimi $3^{\text {rd }}$ the band with $\mathrm{MW}$ of $228 \mathrm{kDa}$ disappeared, fading of MHC 


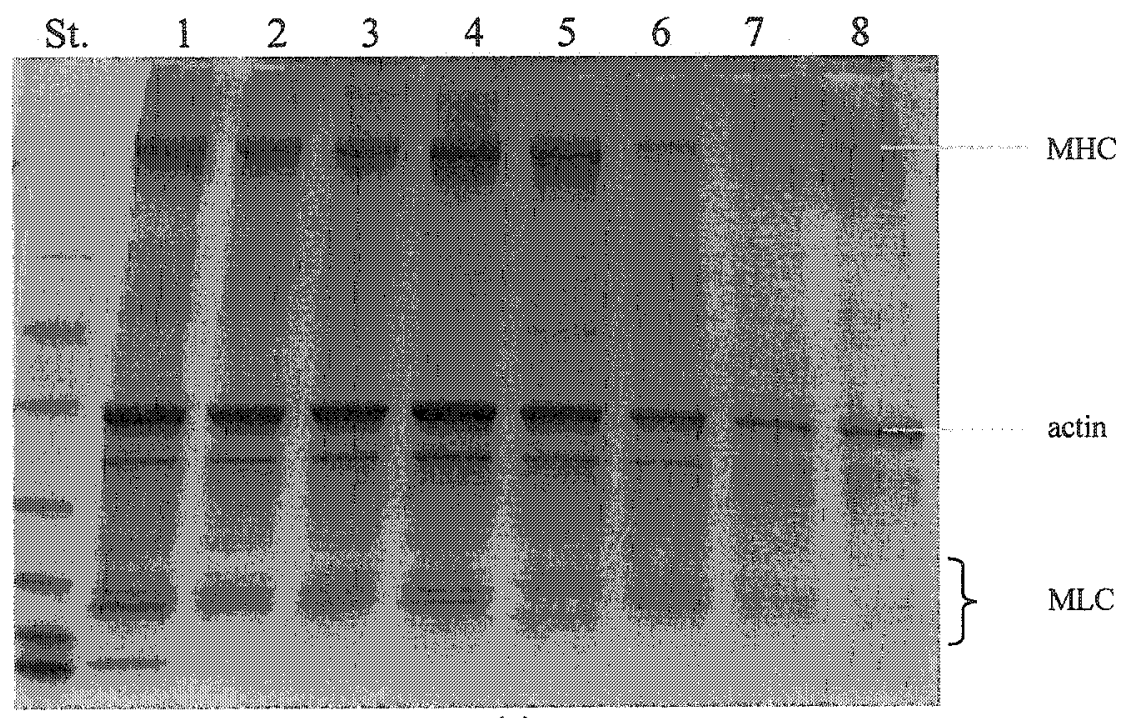

(a)

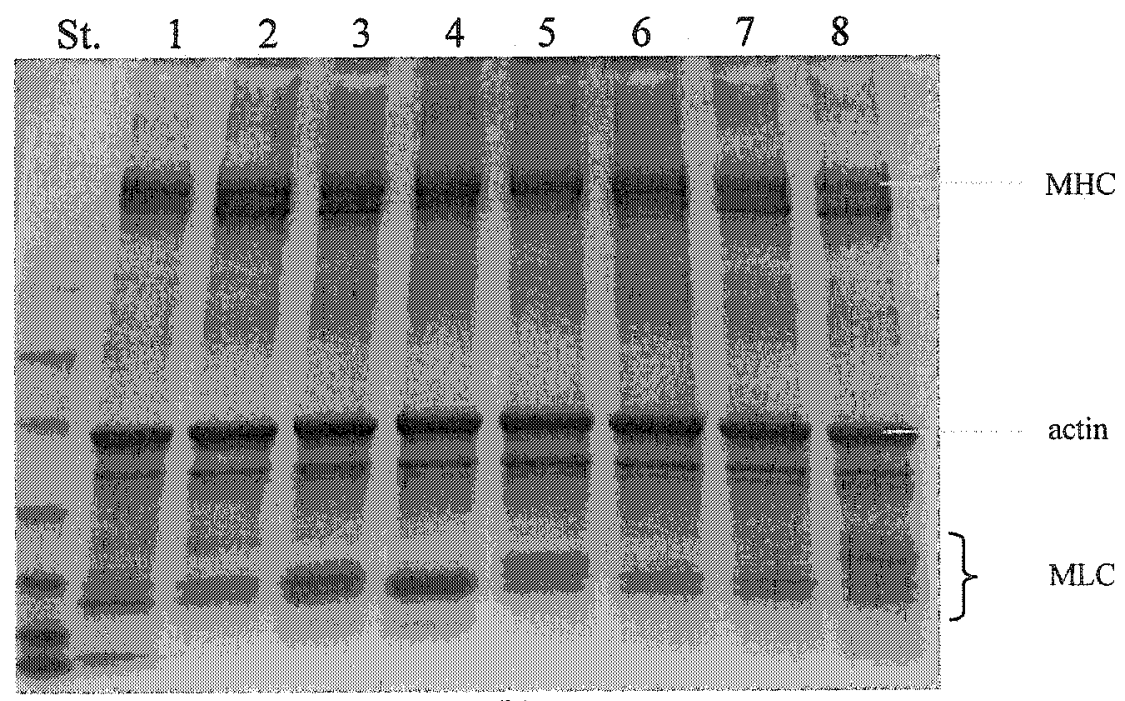

(b)

Figure 4.14: SDS-PAGE patterns of minced fish and surimi after $5 \mathrm{~d}$ storage at $4^{\circ} \mathrm{C}$ : (a) St. broad range molecular weight standard; 1 minced fish; 2 surimi $1^{\text {st }} ; 3$ surimi $2^{\text {nd }} ; 4$ surimi $3^{\text {rd }} ; 5$ market surimi; $6 \mathrm{LO} ; 7 \mathrm{SC} ; 8 \mathrm{CR}$; (b) St. broad range molecular weight standard; 1 minced fish; 2 surimi $3^{\text {rd }} ; 3$ surimi with WPC; 4 surimi with WPI; 5 surimi with SPI; 6 surimi with FM; 7 surimi with $1 \%$ FP; 8 surimi with $3 \%$ FP (for abbreviations refer to Figure 4.6 ). 


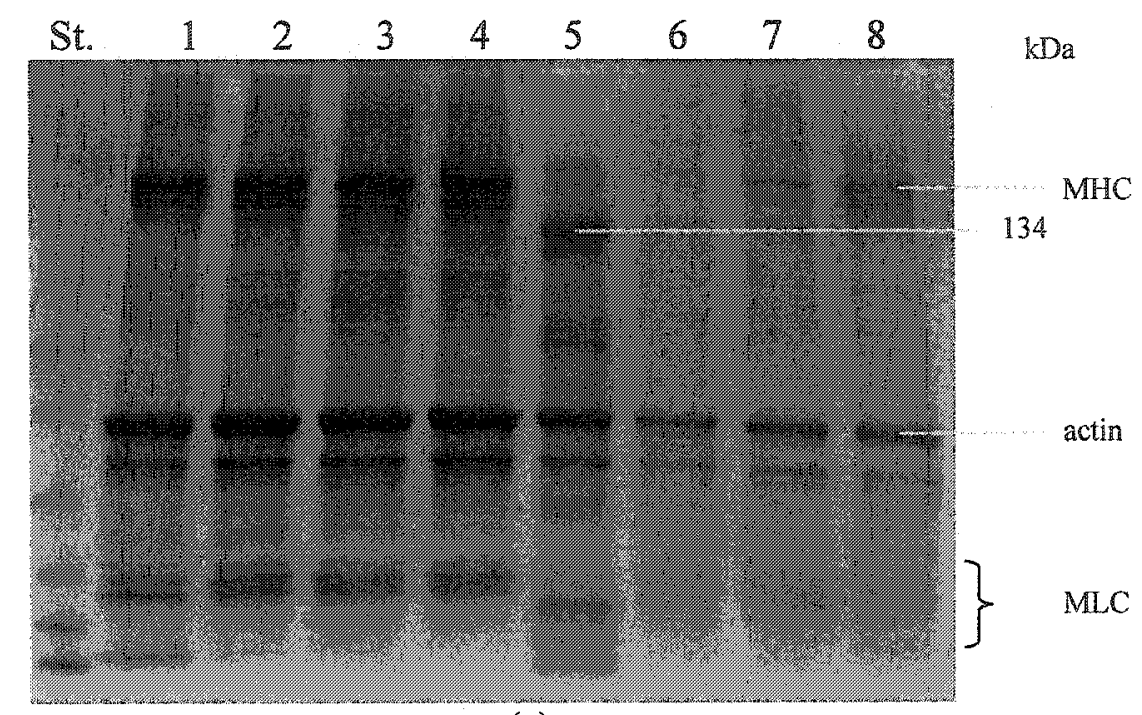

(a)

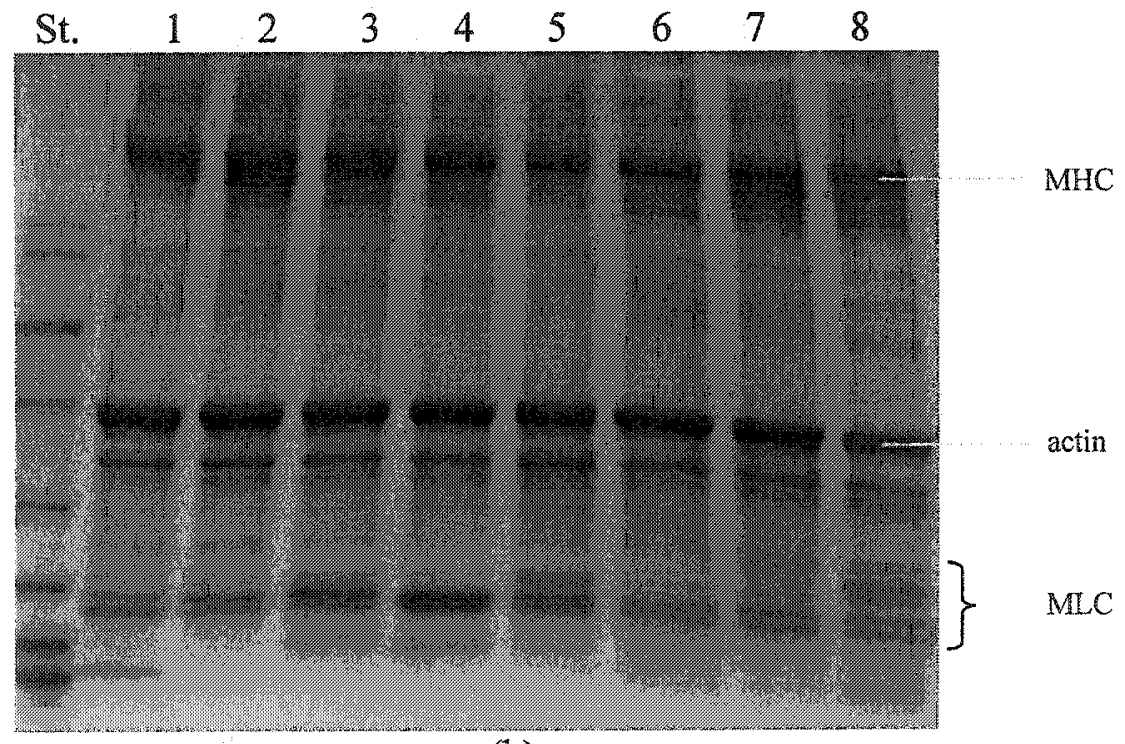

(b)

Figure 4.15: SDS-PAGE patterns of minced fish and surimi after $10 \mathrm{~d}$ storage at $4^{\circ} \mathrm{C}$ : (a) St. broad range molecular weight standard; 1 minced fish; 2 surimi $1^{\text {st }} ; 3$ surimi $2^{\text {nd }} ; 4$ surimi $3^{\text {rd }} ; 5$ market surimi; $6 \mathrm{LO} ; 7 \mathrm{SC} ; 8 \mathrm{CR}$; (b) St. broad range molecular weight standard; 1 minced fish; 2 surimi $3^{\text {rd }} ; 3$ surimi with WPC; 4 surimi with WPI; 5 surimi with SPI; 6 surimi with $\mathrm{FM} ; 7$ surimi with $1 \% \mathrm{FP} ; 8$ surimi with $3 \% \mathrm{FP}$ (for abbreviations refer to Figure 4.6). 


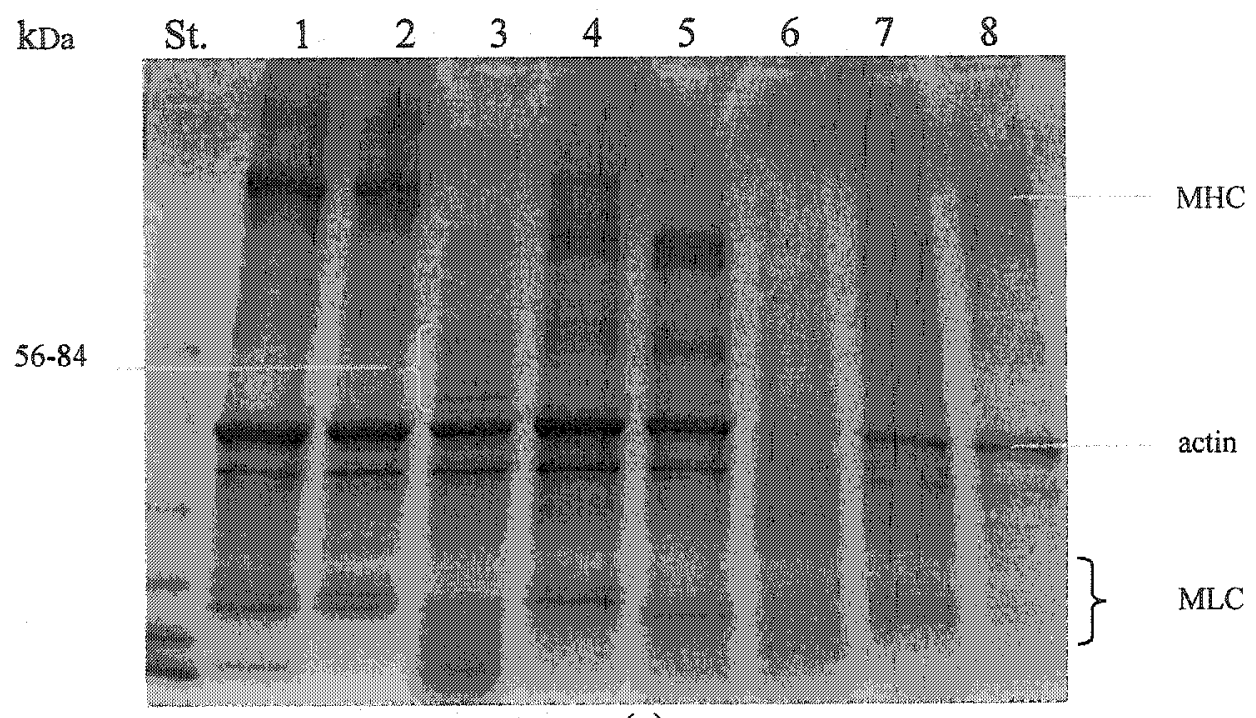

(a)

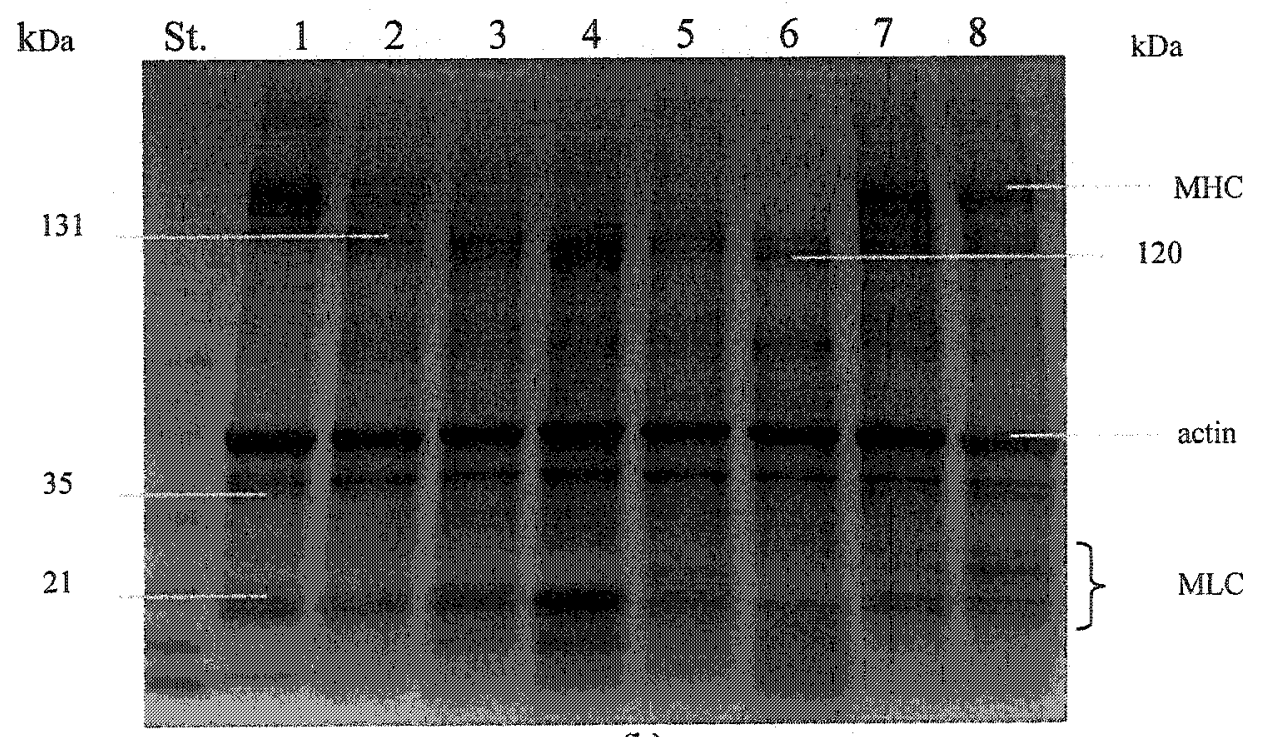

(b)

Tigure 4.16: SDS-PAGE patterns of minced fish and surimi after $15 \mathrm{~d}$ storage at $4^{\circ} \mathrm{C}$ : (a) St. broad range molecular weight standard; 1 minced fish; 2 surimi $1^{\text {st }} ; 3$ surimi $2^{\text {nd }} ; 4$ surimi $3^{\text {rd }} ; 5$ market surimi; $6 \mathrm{LO} ; 7 \mathrm{SC} ; 8 \mathrm{CR}$; (b) St. broad range molecular weight standard; 1 minced fish; 2 surimi $3^{\text {rd, }} 3$ surimi with WPC; 4 surimi with WPI; 5 surimi with SPI; 6 surimi with FM; 7 surimi with $1 \% \mathrm{FP} ; 8$ surimi with $3 \%$ FP (for abbreviations refer to Figure 4.6). 
occurred, and a new band with MW of $131 \mathrm{kDa}$ appeared. The changes in market raw surimi were the same as those in laboratory-made surimi (surimi $3^{\text {rd }}$ ). In addition, two MLC bands with MW of 23 and $21 \mathrm{kDa}$ also disappeared. In three Alaska pollock flavored products fading of $\mathrm{MHC}$ and actin happened. In the case of lobster-flavored market surimi (LO), MHC almost disappeared and fading of actin was more significant than for the other two products.

Figure $4.16 \mathrm{~b}$ reveals that after $15 \mathrm{~d}$ storage at $4^{\circ} \mathrm{C}$ the band with $\mathrm{MW}$ of 228 kDa disappeared in all samples except for minced fish. Furthermore, the band with MW of $136 \mathrm{kDa}$ disappeared in all samples except for minced fish and surimi with added $1 \%$ and $3 \%$ flaxseed protein with lower band intensity compared to time 0 . Minced fish was relatively stable showing only fading of two bands with MW of 136 and $23 \mathrm{kDa}$. In other samples MHC was almost lost especially in surimi with added flaxseed meal. Only surimi samples with $1 \%$ and $3 \%$ flaxseed protein could maintain the MHC intensity as in minced fish in the same gel. In surimi $3^{\text {rd }}$ also fading of MHC and a MLC band with MW of $23 \mathrm{kDa}$ occurred. In surimi samples with added WPC, WPI, and SPI, fading of MHC and a MLC band with MW of $23 \mathrm{kDa}$ were observed. In surimi with added flaxseed meal and protein two new bands appeared under MHC with MW of 131 and $120 \mathrm{kDa}$. A band with MW of $35 \mathrm{kDa}$ was disappeared in all samples except in minced fish and surimi with added $1 \%$ and $3 \%$ flaxseed protein. In surimi with flaxseed meal two MLC bands with MW of 23 and $21 \mathrm{kDa}$ were lost.

Flaxseed protein was the only additive that could inhibit degradation of $\mathrm{MHC}$, and maintain the MHC and also actin with the same intensity as minced fish. Furthermore, flaxseed protein could prevent degradation of MLC bands and the band 
with MW of $35 \mathrm{kDa}$. Since the addition of $3 \%$ FP may result in off-flavors, addition of $1 \% \mathrm{FP}$ was also investigated in this study,

Results of multiple detection methods for denaturation indicate that every kind of muscle protein undergoes denaturation during frozen storage, although the ease and rate of denaturation depends on the kind of protein and the kind of fish. It is the collective result of such denaturation that brings about undesirable changes in the functional properties of meat (Matsumoto and Noguchi, 1992).

\subsubsection{FTIR/ATR Spectroscopy}

Figure 4.17 depicts the deconvolved FTIR/ATR spectra of different cryoprotectants (top) and the percentage of various secondary structures (bottom). Among the five different additives, WPC and flaxseed meal had the highest ratio of $\alpha$ helix to $\beta$-sheet structure content. All additives had the $\alpha$-helix content in the range of 15 to $17 \%$ and $\beta$-sheet content in the range of 27 to $31 \%$.

The secondary structure of the major flaxseed protein, globulin (the $12 \mathrm{~S}$ fraction), has been determined by circular dichroism studies. The results suggest that the protein consists of $3-4 \% \alpha$-helix structure, $17 \% \beta$-sheet and nearly $80 \%$ aperiodic structure (Madhusudhan and Singh, 1985a). The low MW albumins make 20\% of the total flaxseed protein, which contains a large amount of $\alpha$-helix (26-32\%) and $\beta$-sheet structure (51\%) (Oomah and Mazza, 1993). 

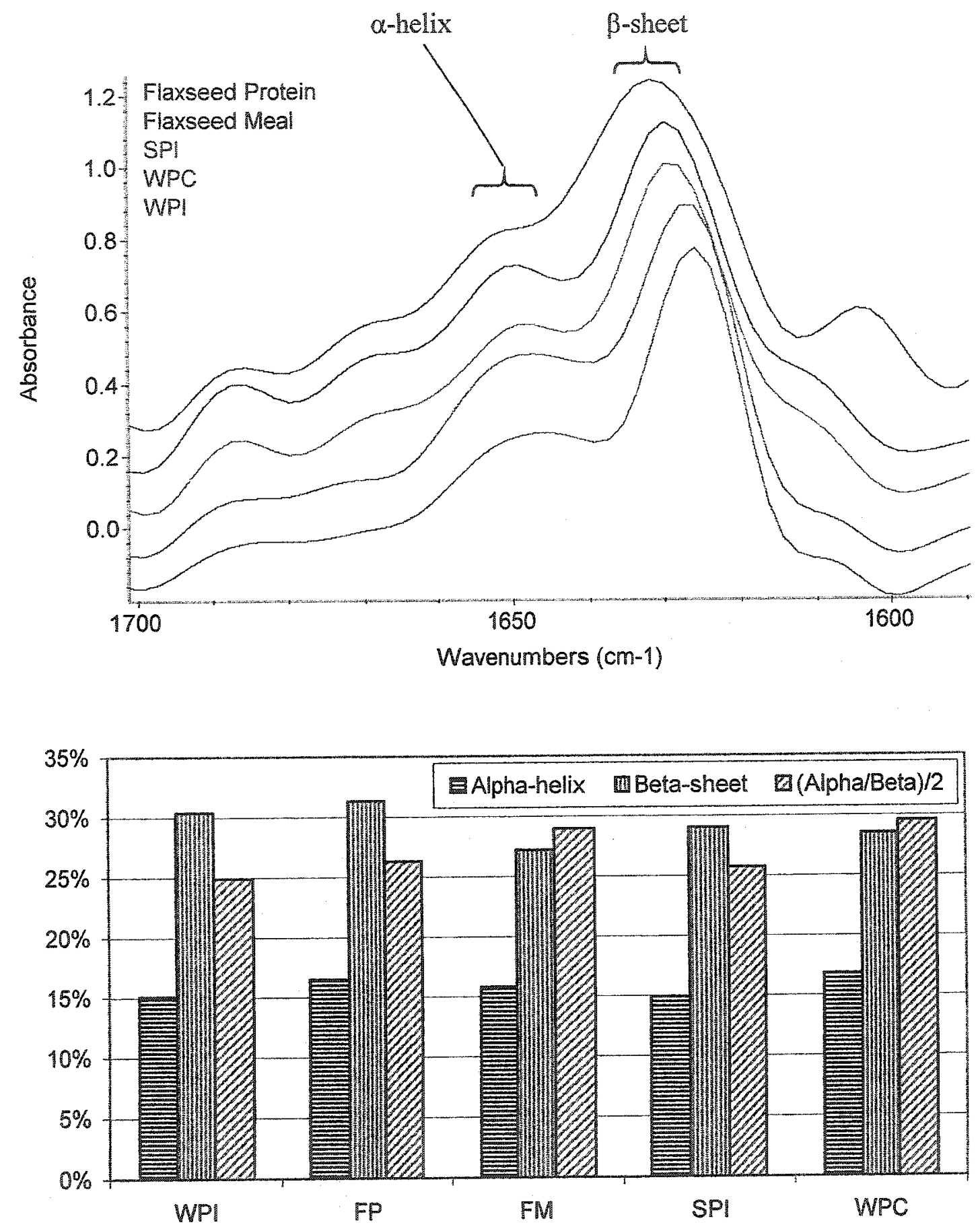

Figure 4.17: Stacked plot of deconvolved FTIR/ATR spectra of different cryoprotectants (top); percentage of $\alpha$-helix, $\beta$-sheet structures and their ratio (bottom): whey protein isolate (WPI), flaxseed protein (FP), flaxseed meal (FM), soy protein isolate (SPI), whey protein concentrate (WPC). The spectra have been offset for clarity. 
Although early investigations indicated that aggregation of proteins was the primary change occurring during frozen storage, more recent studies have indicated that conformational changes in the proteins also occur (MacDonald et al., 2000; Matsumoto and Noguchi, 1992). Actin is a globular protein containing little helical structure; therefore, changes in functional attributes of actin are due to unfolding nonhelical structure during frozen storage. Conformational changes can be prevented when the protein is frozen with added cryoprotectants (Matsumoto and Noguchi, 1992).

The deconvolved FTIR/ATR spectra and percentage of different protein conformations in minced fish during storage at $4^{\circ} \mathrm{C}$, and $-20^{\circ} \mathrm{C}$ are shown in Figure 4.18. The results indicate that minced fish is relatively stable during storage, which is consistent with the findings from electrophoresis analyses. Only a slight increase in the ratio of $\alpha$-helix to $\beta$-sheet structure was observed during storage at both high and low temperatures.

The FTIR/ATR results for surimi from first washing cycle (surimi $1^{\text {st }}$ ) indicate a decrease in $\alpha$-helix and an increase in $\beta$-sheet structures content after 6 mo storage at $-20^{\circ} \mathrm{C}$. In contrast, the ratio of $\alpha$-helix to $\beta$-sheet structure increased after $15 \mathrm{~d}$ storage at $4^{\circ} \mathrm{C}$ (Figure 4.19 ). 

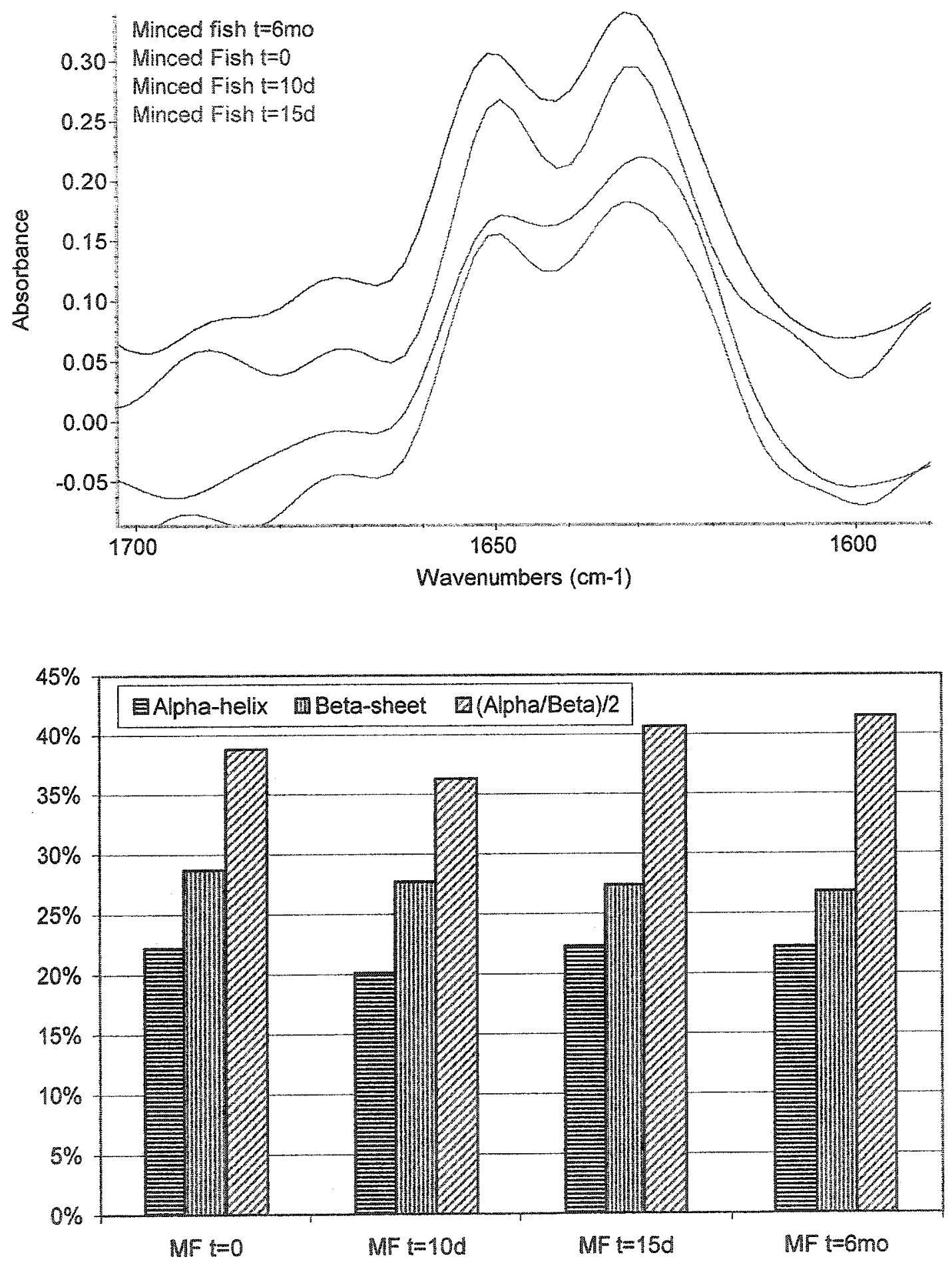

Figure 4.18: Stacked plot of deconvolved FTIR/ATR spectra of minced fish during storage at $4^{\circ} \mathrm{C}$ and after 6 mo at $-20^{\circ} \mathrm{C}$ (top); percentage of $\alpha$-helix, $\beta$-sheet structures and their ratio (bottom). The spectra have been offset for clarity. 

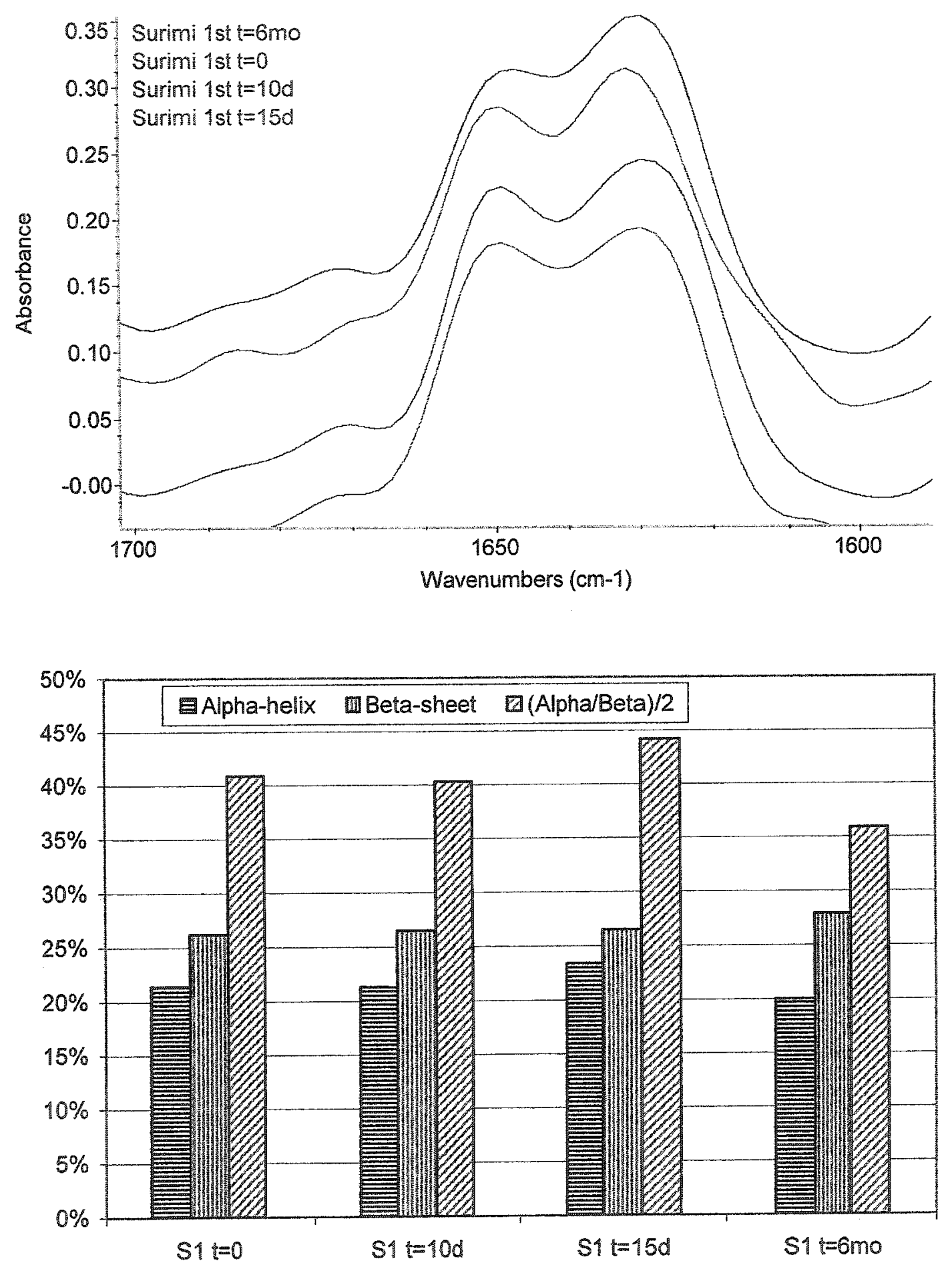

Tigure 4.19: Stacked plot of deconvolved FTR/ATR spectra of surimi $1^{\text {st }}$ during storage at $4^{\circ} \mathrm{C}$ and after $6 \mathrm{mo}$ at $-20^{\circ} \mathrm{C}$ (top); percentage of $\alpha$-helix, $\beta$-sheet structures and their ratio (bottom). The spectra have been offset for clarity. 
The secondary structure of proteins remained relatively stable in surimi $2^{\text {nd }}$ after 6 mo frozen storage. There was a decrease of $\alpha$-helix content after 10 and $15 \mathrm{~d}$ storage at $4^{\circ} \mathrm{C}$. However, $\beta$-sheet structure content remained unchanged after $10 \mathrm{~d}$ and decreased after $15 \mathrm{~d}$. Therefore, the ratio of $\alpha$-helix to $\beta$-sheet structure decreased after $10 \mathrm{~d}$ but increased after $15 \mathrm{~d}$ storage at $4^{\circ} \mathrm{C}$ (Figure 4.20).

In surimi $3^{\text {rd }}$ (raw surimi), there was a slight increase in $\alpha$-helix and a decrease in $\beta$-sheet contents resulting in a higher ratio of $\alpha$-helix to $\beta$-sheet structure after 6 mo storage at $-20^{\circ} \mathrm{C}$. Sultanbawa and Li-Chan (2001) reported that the Raman spectral data showed an increase in the percent $\alpha$-helix structure content in natural actomyosin and surimi after frozen storage in the absence of cryoprotectants. They also mentioned that SS bonds were formed during storage of natural actomyosin in the absence of cryoprotectants. During storage at $4^{\circ} \mathrm{C}, \alpha$-helix content increased in surimi $3^{\text {rd }}$. After $10 \mathrm{~d}$ storage at this temperature $\beta$-sheet content remained unchanged, but after $15 \mathrm{~d}$ it showed a decrease. Overall, the ratio of $\alpha$-helix to $\beta$-sheet contents increased. This increase was much higher after $15 \mathrm{~d}$ storage at $4^{\circ} \mathrm{C}$ (Figure 4.21 ).

Market raw surimi was relatively stable after 6 mo storage at $-20^{\circ} \mathrm{C}$ with the same $\alpha$-helix and $\beta$-sheet contents resulting in the unchanged ratio of these structures. The ratio of $\alpha$-helix to $\beta$-sheet contents significantly increased after $15 \mathrm{~d}$ storage at $4^{\circ} \mathrm{C}$ (Figure 4.22). 

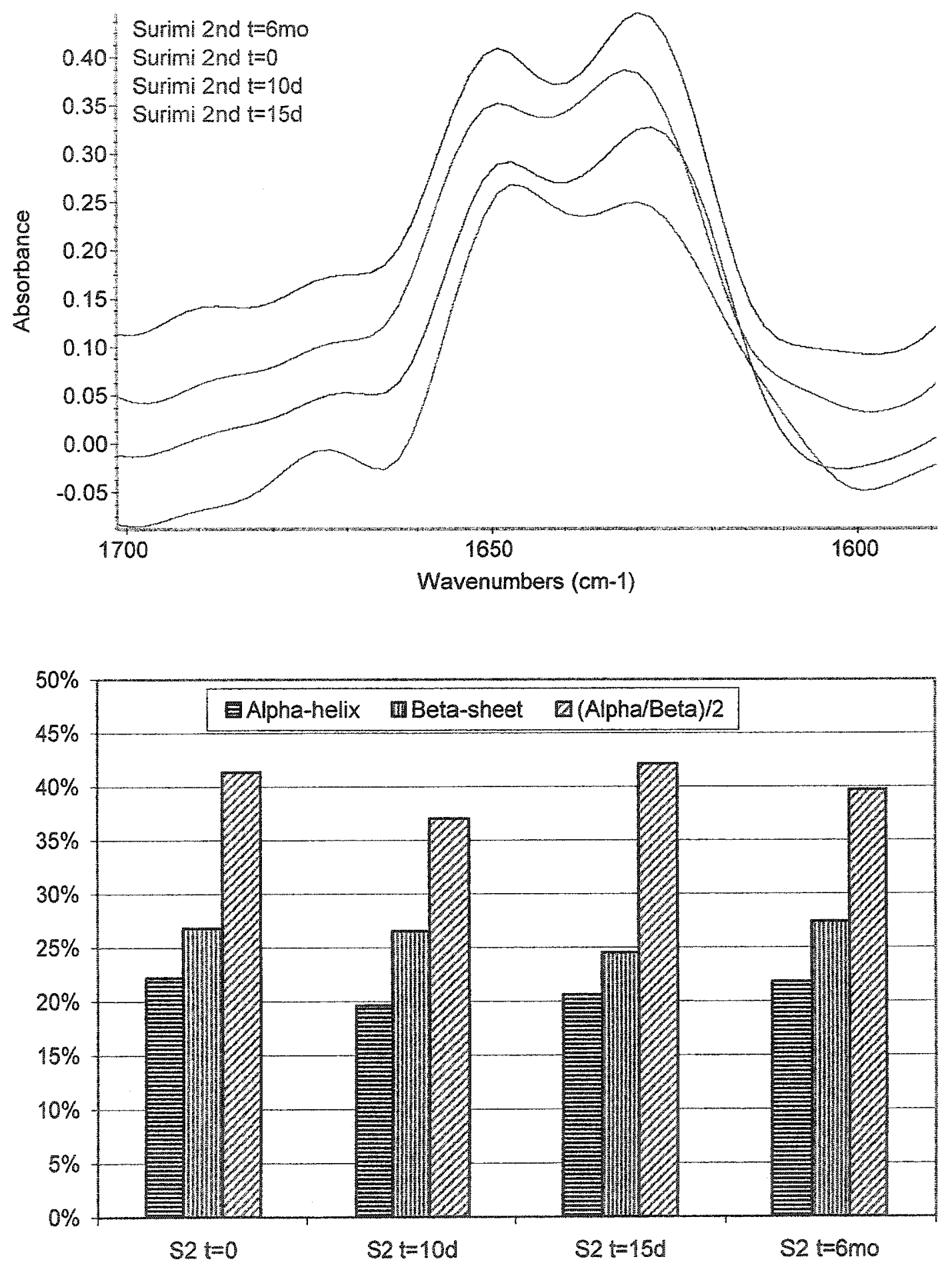

Tigure 4.20: Stacked plot of deconvolved FTR/ATR spectra of surimi $2^{\text {nd }}$ during storage at $4^{\circ} \mathrm{C}$ and after 6 mo at $-20^{\circ} \mathrm{C}$ (top); percentage of $\alpha$-helix, $\beta$-sheet structures and their ratio (bottom). The spectra have been of 

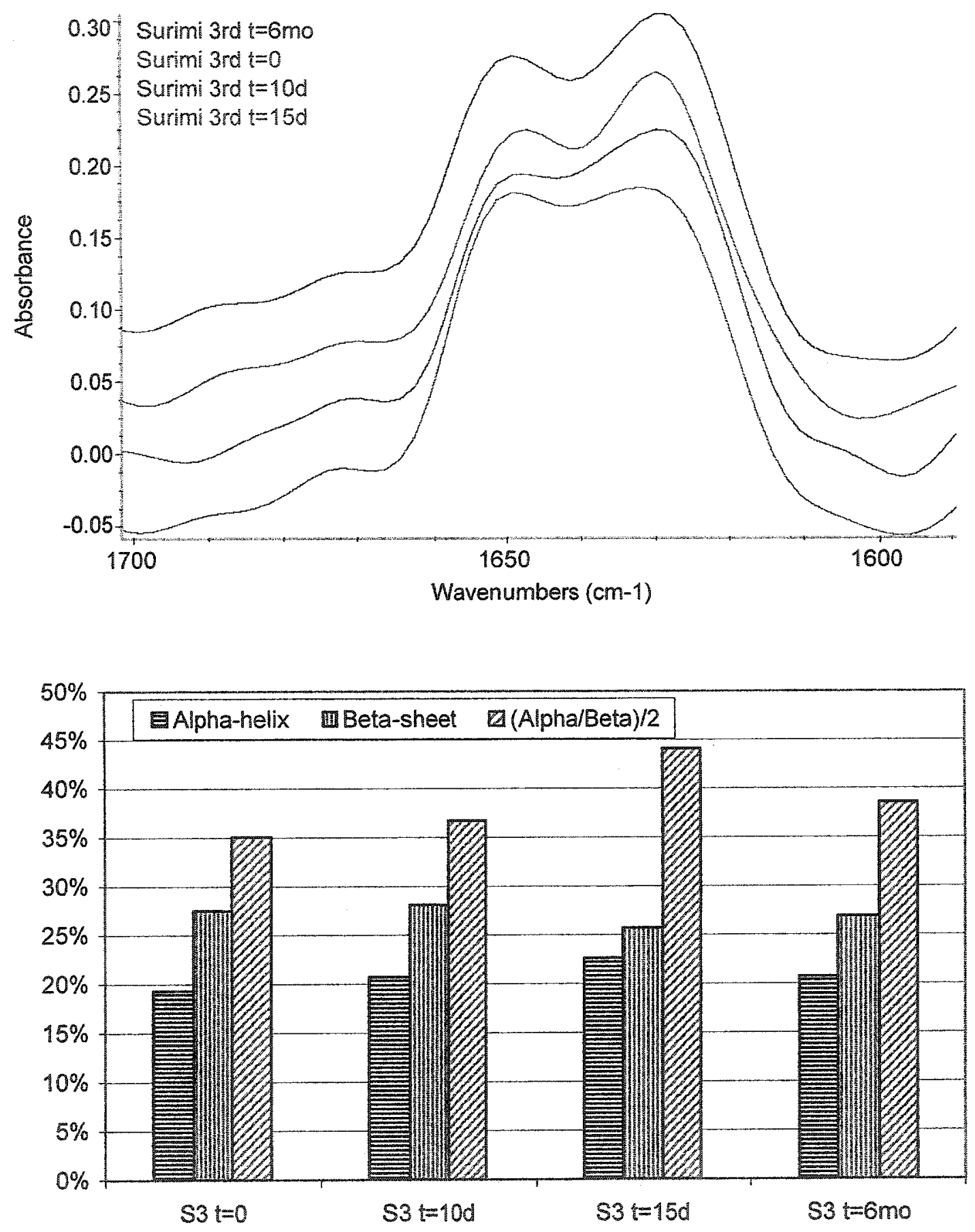

Fighre 4.21: Stacked plot of deconvolved FTR/ATR spectra of surimi $3^{\text {rd }}$ during storage at $4^{\circ} \mathrm{C}$ and after 6 mo at $-20^{\circ} \mathrm{C}$ (top); percentage of $\alpha$-helix, $\beta$-sheet structures and their ratio (bottom). The spectra have been offset for clarity. 

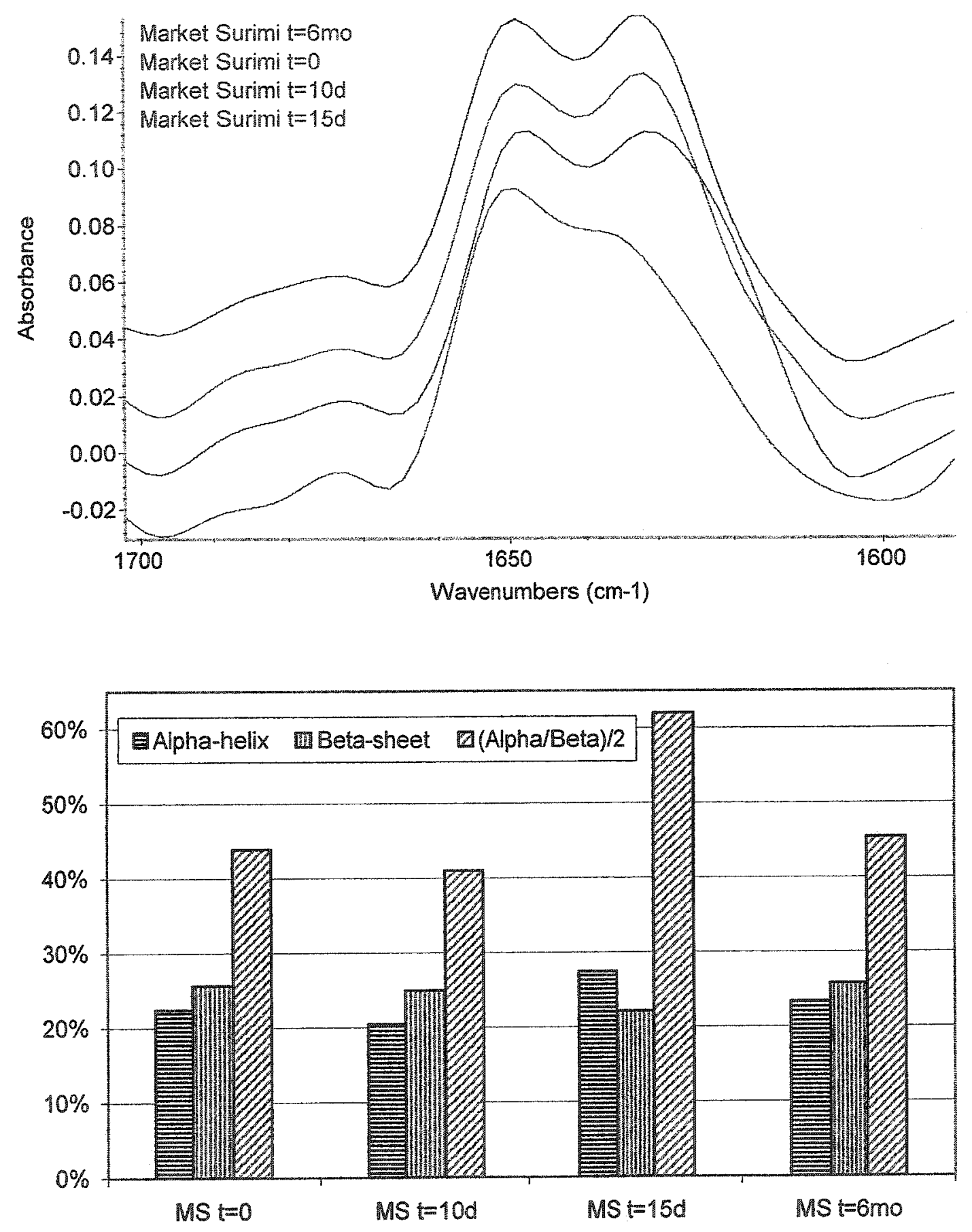

Figure 4.22: Stacked plot of deconvolved FTIR/ATR spectra of market surimi during storage at $4{ }^{\circ} \mathrm{C}$ and after $6 \mathrm{mo}$ at $-20^{\circ} \mathrm{C}$ (top); percentage of $\alpha$-helix, $\beta$-sheet structures and their ratio (bottom). The spectra have been offset for clarity. 
The percentage of $\alpha$-helix in lobster-flavored market surimi (LO) was almost unchanged after 6 mo storage at $-20^{\circ} \mathrm{C}$, while the amount of $\beta$-sheet structure slightly increased resulting in a lower ratio of $\alpha$-helix to $\beta$-sheet structure contents. There was an increase in $\alpha$-helix and a decrease in $\beta$-sheet structure contents resulting in a higher ratio of $\alpha$-helix to $\beta$-sheet especially after $15 \mathrm{~d}$ storage at $4^{\circ} \mathrm{C}$ (Figure 4.23 ).

In scallop-flavored market surimi (SC), the ratio of $\alpha$-helix to $\beta$-sheet structure contents significantly decreased after 6 mo storage at $-20^{\circ} \mathrm{C}$. During storage at $4^{\circ} \mathrm{C}$ also the ratio of $\alpha$-helix to $\beta$-sheet structure contents decreased. This decrease was higher at time $15 \mathrm{~d}$ compared to time $10 \mathrm{~d}$ (Figure 4.24).

In crab-flavored market surimi $(\mathrm{CR})$ the ratio of $\alpha$-helix to $\beta$-sheet structure contents increased after 6 mo storage at $-20^{\circ} \mathrm{C}$. The ratio of $\alpha$-helix to $\beta$-sheet structure was higher at time $10 \mathrm{~d}$ than at time $15 \mathrm{~d}$ storage at $4^{\circ} \mathrm{C}$; it was at the same level as at time 6 mo of storage at $-20^{\circ} \mathrm{C}$ (Figure 4.25 ).

There was a decrease in $\alpha$-helix and an increase in $\beta$-sheet structure contents resulting in lower ratio of $\alpha$-helix to $\beta$-sheet after 6 mo storage of surimi with added whey protein concentrate at $-20^{\circ} \mathrm{C}$. During storage at $4^{\circ} \mathrm{C}$, a decrease in othelix content was observed after $15 \mathrm{~d}$. Since the $\beta$-sheet content remained unchanged, the ratio of $\alpha$-helix to $\beta$-sheet decreased after $15 \mathrm{~d}$ storage at $4^{\circ} \mathrm{C}$ (Figure 4.26 ).

Sultanbawa and Li-Chan (2001) showed that the percent $\alpha$-helix decreased after freezing for both natural actomyosin and surimi treatments with commercial blend ( $4 \%$ sucrose and $4 \%$ sorbitol) by Raman analysis; these were the treatments that showed good gel strength. In another study using Raman spectroscopy, Ogawa et al. (1999) 

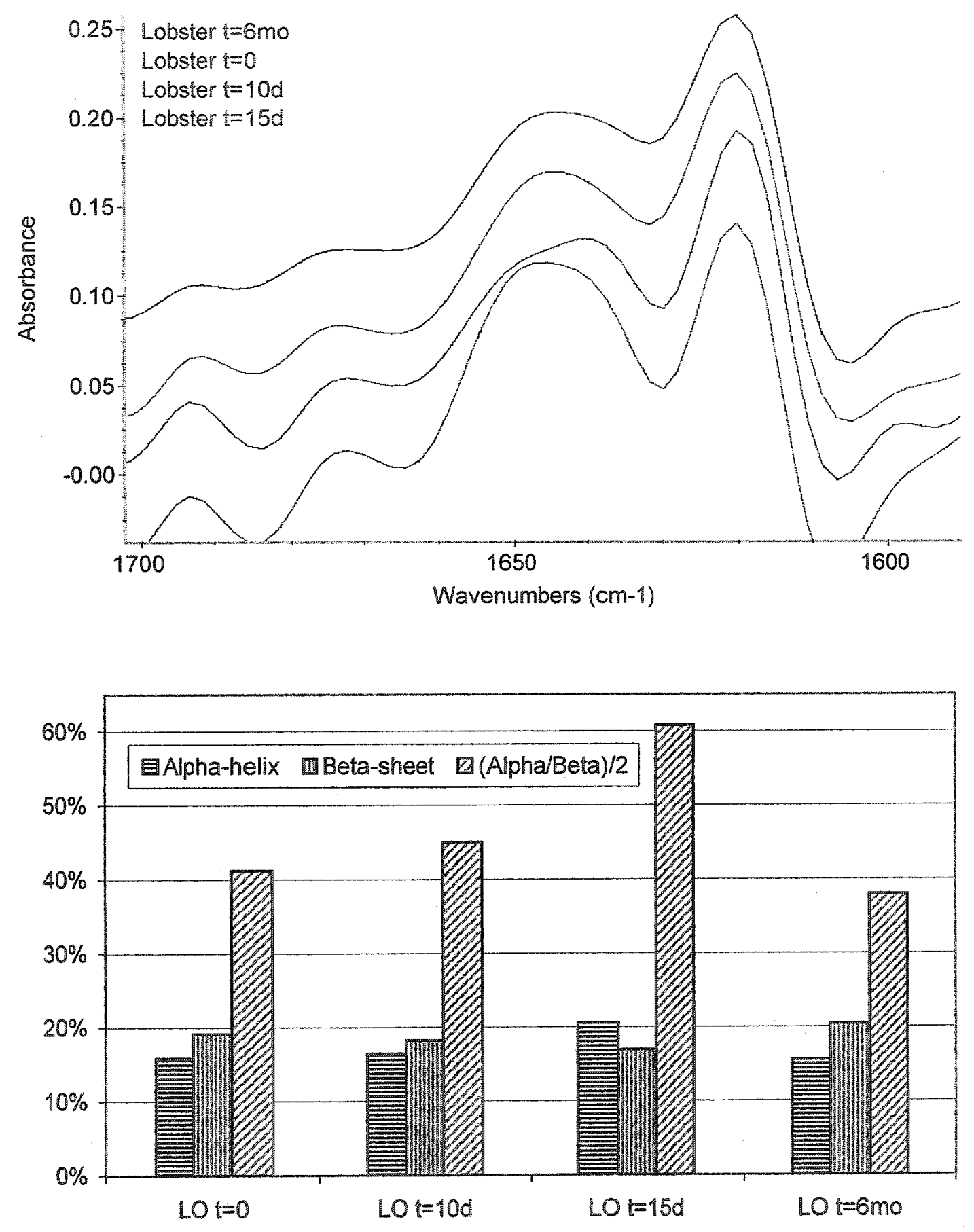

Figure 4.23: Stacked plot of deconvolved FTIR/ATR spectra of lobster-flavored market surimi during storage at $4^{\circ} \mathrm{C}$ and after 6 mo at $-20^{\circ} \mathrm{C}$ (top); percentage of $\alpha$ helix, $\beta$-sheet structures and their ratio (bottom). The spectra have been offset for clarity. 

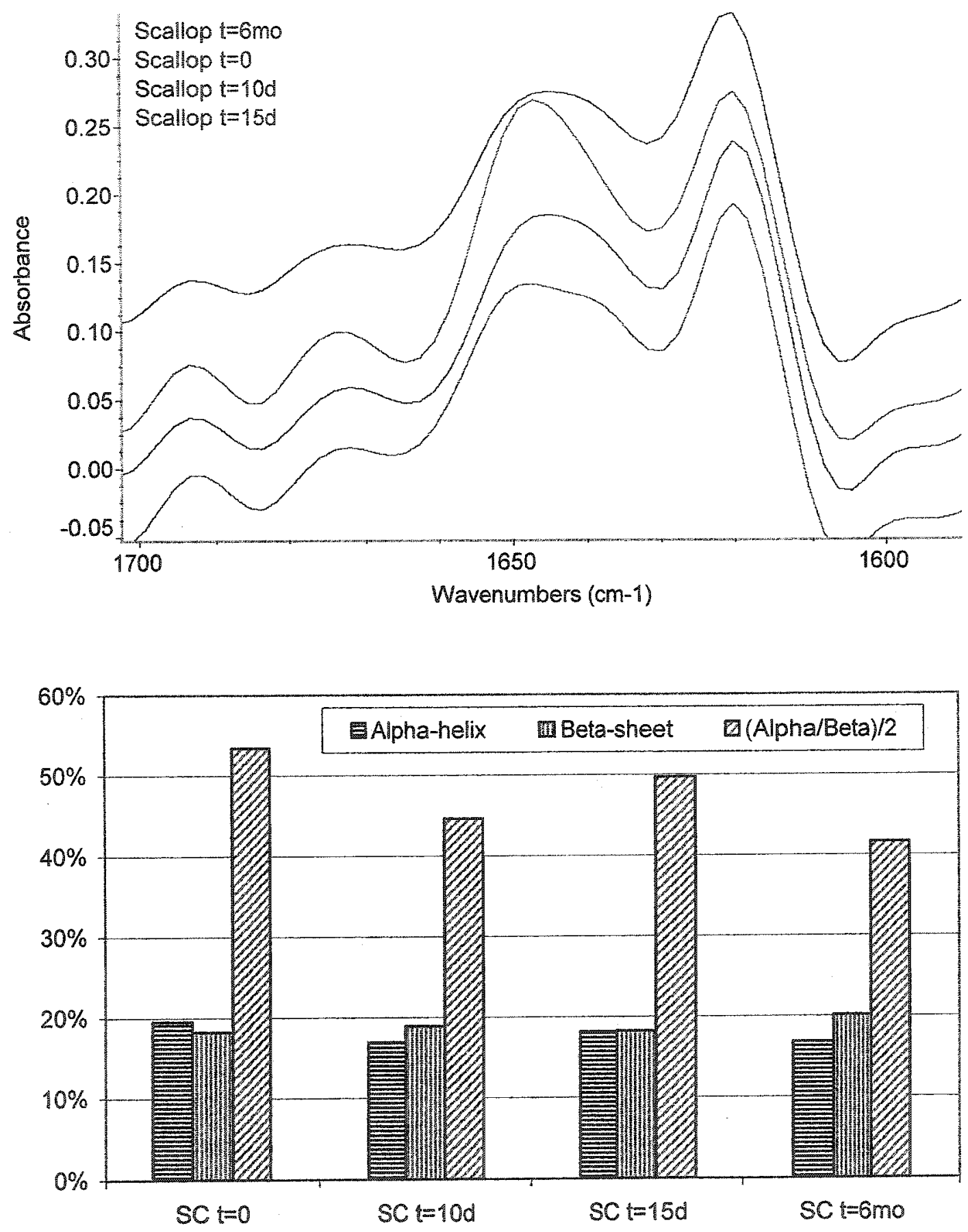

Figure 4.24: Stacked plot of deconvolved FTIR/ATR spectra of scallop-flavored market surimi during storage at $4^{\circ} \mathrm{C}$ and after $6 \mathrm{mo}$ at $-20^{\circ} \mathrm{C}$ (top); percentage of $\alpha$ helix, $\beta$-sheet structures and their ratio (bottom). The spectra have been offset for clarity. 

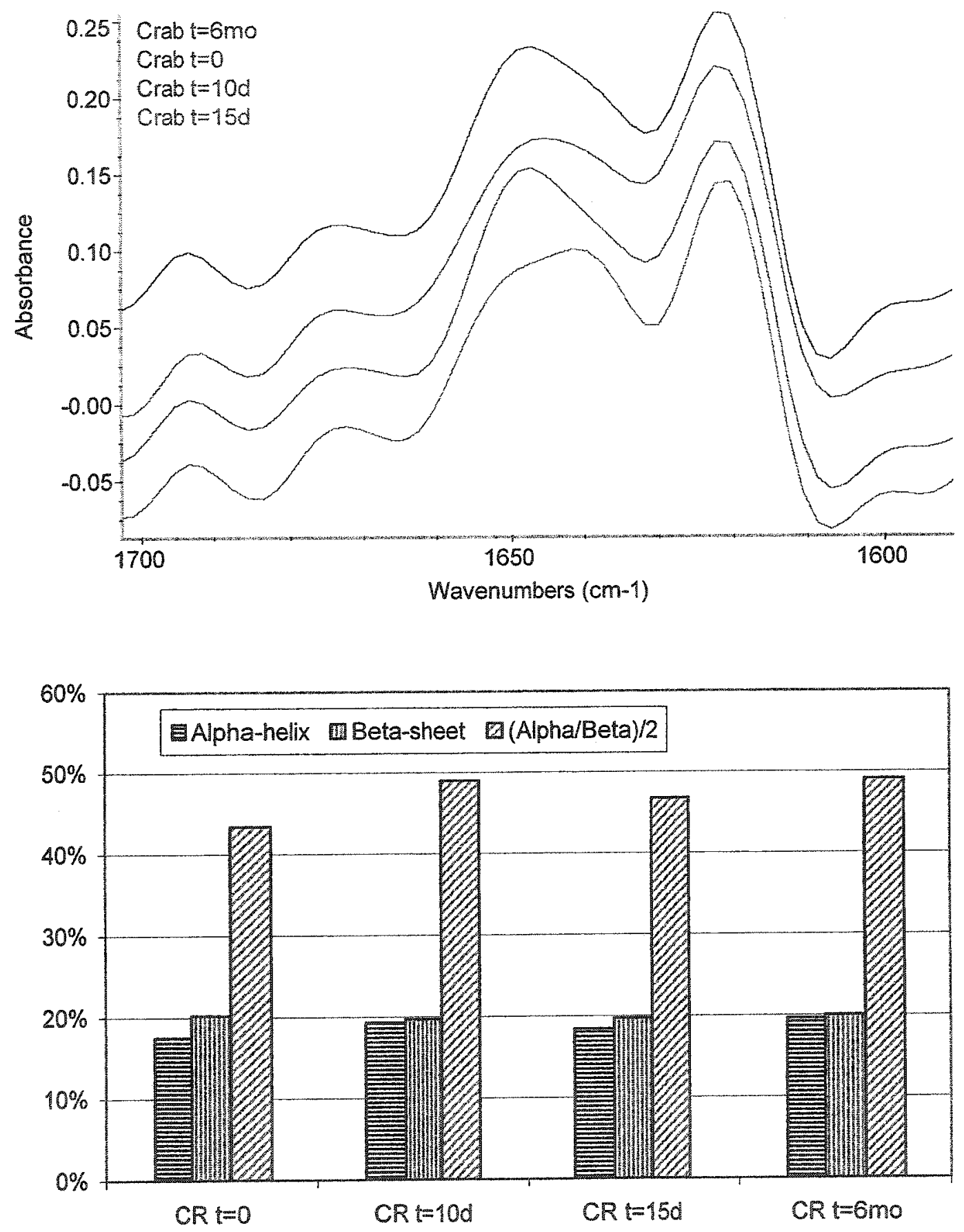

Figure 4.25: Stacked plot of deconvolved FTIR/ATR spectra of crab-flavored market surimi during storage at $4^{\circ} \mathrm{C}$ and after $6 \mathrm{mo}$ at $-20^{\circ} \mathrm{C}$ (top); percentage of $\alpha$ helix, $\beta$-sheet structures and their ratio (bottom). The spectra have been offset for clarity. 

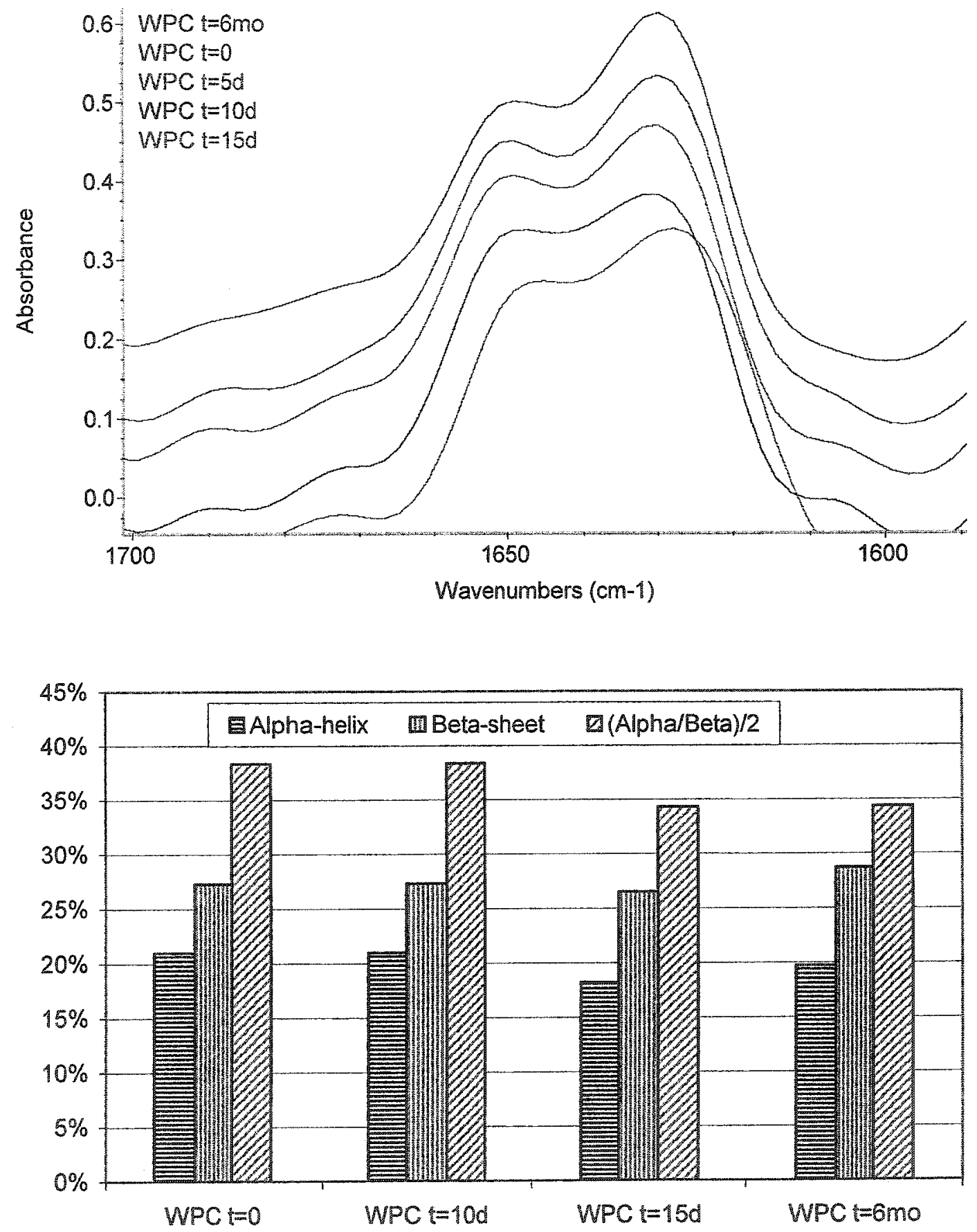

Tigure 4.26: Stacked plot of deconvolved FTIR/ATR spectra of surimi with added whey protein concentrate during storage at $4^{\circ} \mathrm{C}$ and after $6 \mathrm{mo}$ at $-20^{\circ} \mathrm{C}$ (top); percentage of $\alpha$-helix, $\beta$-sheet structures and their ratio (bottom). The spectra have been offset for clarity. 
reported that gel formation of fish actomyosins requires a slow unfolding of the $\alpha$ helix, and that the dissociation of $\alpha$-helix is closely associated with the low temperature gelling phenomenon (setting) of actomyosin.

A slight decrease in both $\alpha$-helix and $\beta$-sheet structure contents was observed in surimi with added whey protein isolate after 6 mo storage at $-20^{\circ} \mathrm{C}$; thus, the ratio of $\alpha$-helix to $\beta$-sheet remained almost unchanged. This ratio increased during storage at $4^{\circ} \mathrm{C}$, and was higher at $10 \mathrm{~d}$ compared to $15 \mathrm{~d}$ (Figure 4.27).

There was a decrease in both $\alpha$-helix and $\beta$-sheet structures contents resulting in a slight decrease in their ratio after 6 mo storage of surimi with added soy protein isolate (SPI) at $-20^{\circ} \mathrm{C}$. During storage at $4^{\circ} \mathrm{C}$ the percentage of $\alpha$-helix increased slightly, and $\beta$-sheet content decreased. Therefore, there was an increase in the ratio of $\alpha$-helix to $\beta$-sheet structure (Figure 4.28).

There was a decrease in $\alpha$-helix and an increase in $\beta$-sheet structure contents resulting in a higher ratio of $\alpha$-helix to $\beta$-sheet after 6 mo storage of surimi with added flaxseed meal (FM) at $-20^{\circ} \mathrm{C}$. During storage at $4^{\circ} \mathrm{C}$ for $15 \mathrm{~d}$, surimi showed a higher ratio of $\alpha$-helix to $\beta$-sheet compared to $10 \mathrm{~d}$ (Figure 4.29).

In surimi with added $1 \%$ flaxseed protein, no changes happened in $\alpha$-helix and $\beta$-sheet contents, and consequently their ratio, after 6 mo storage at $-20^{\circ} \mathrm{C}$; this is consistent with electrophoresis results. The results indicate that flaxseed proteins are effective in maintaining the secondary structure of fish proteins during frozen storage. During storage at $4^{\circ} \mathrm{C}$, surimi showed a much higher ratio of $\alpha$-helix to $\beta$-sheet after 15 d compared to $10 \mathrm{~d}$ (Figure 30). 

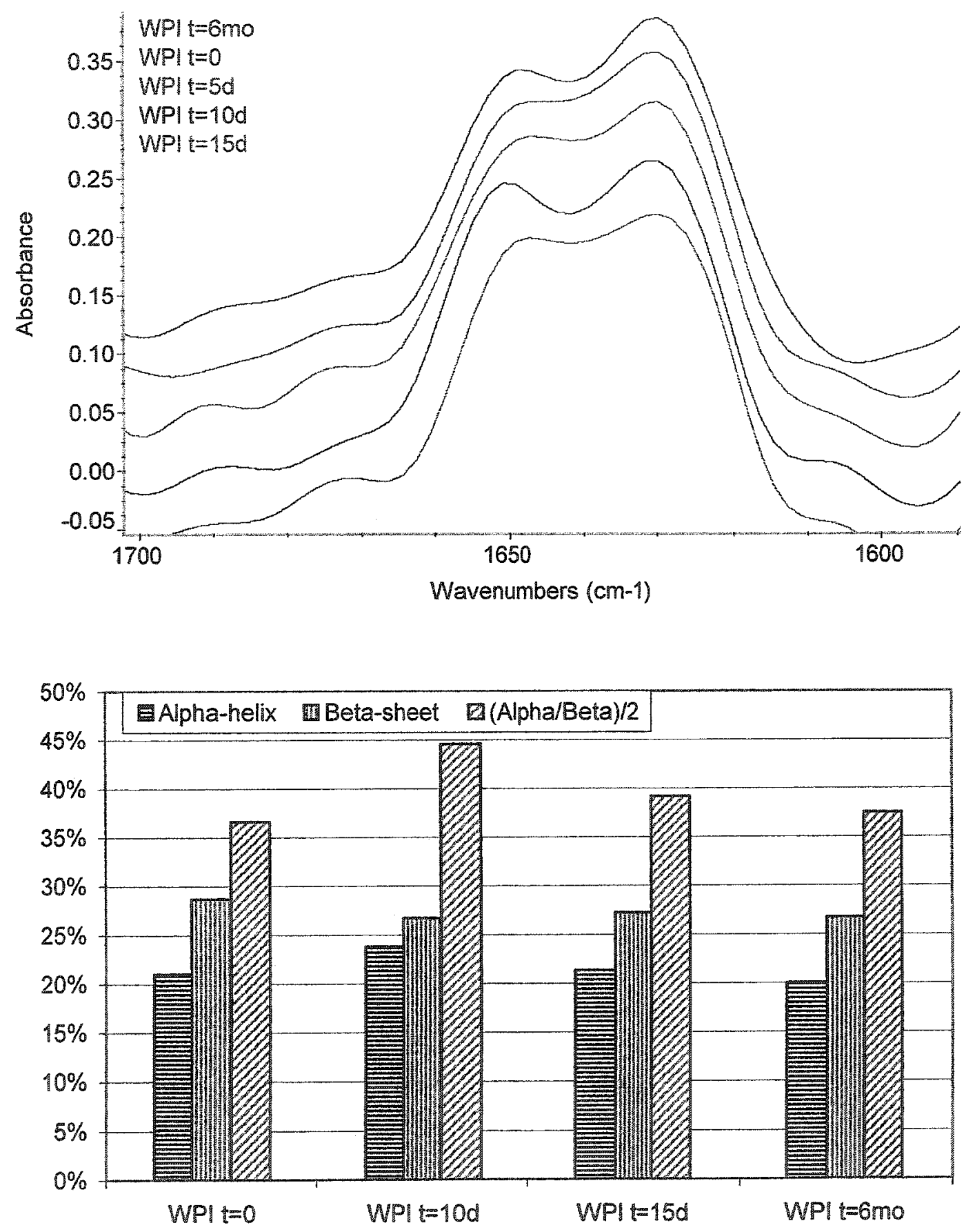

Figure 4.27: Stacked plot of deconvolved FTIR/ATR spectra of surimi with added whey protein isolate during storage at $4^{\circ} \mathrm{C}$ and after $6 \mathrm{mo}$ at $-20^{\circ} \mathrm{C}$ (top); percentage of $\alpha$-helix, $\beta$-sheet structures and their ratio (bottom). The spectra have been offset for clarity. 

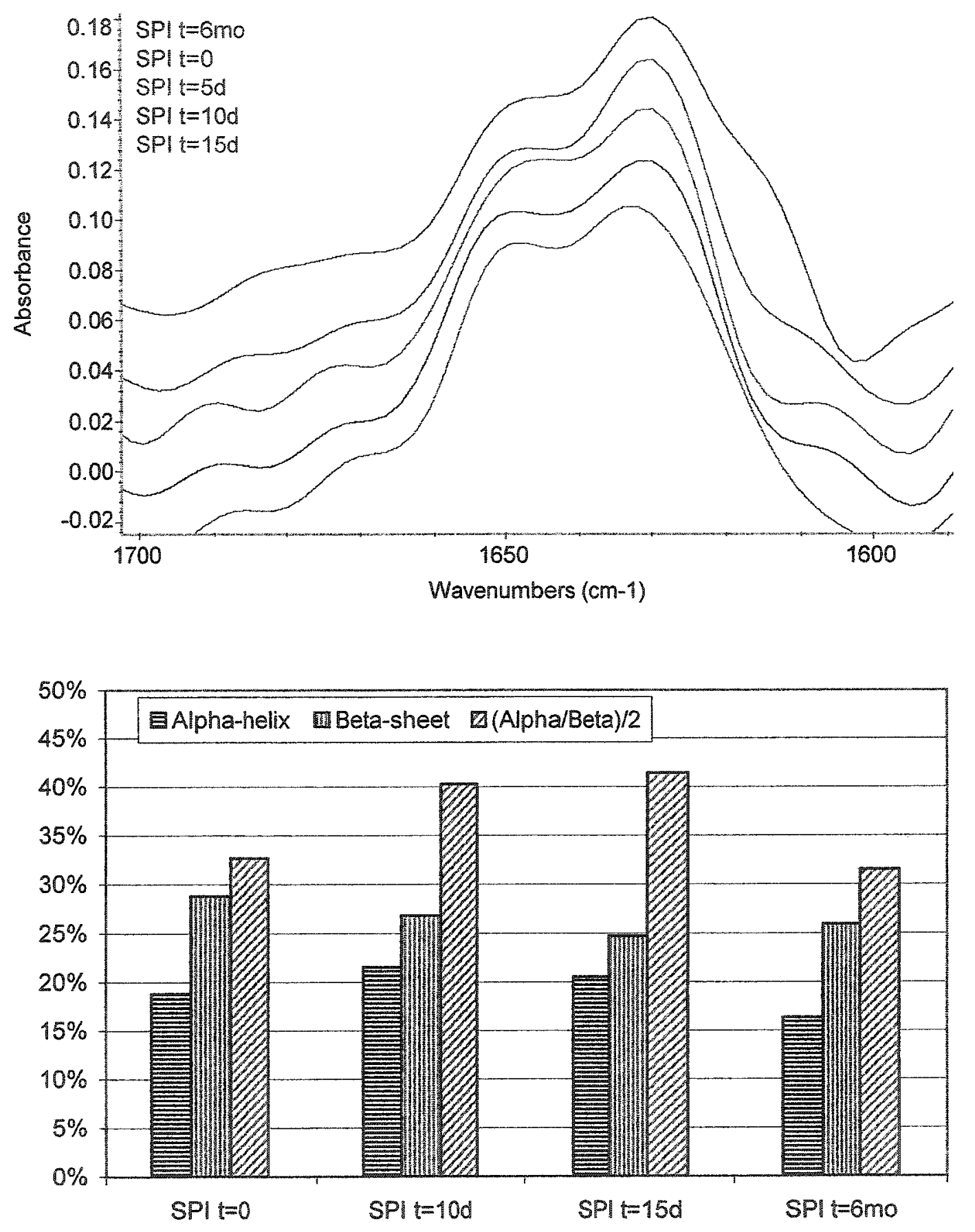

Tigure 428: Stacked plot of deconvolved FTR/ATR spectra of surimi with added soy protein isolate during storage at $4^{\circ} \mathrm{C}$ and after 6 mo at $-20^{\circ} \mathrm{C}$ (top); percentage of $\alpha$-helix, $\beta$-sheet structures and their ratio (bottom). The spectra have been offset for clarity. 

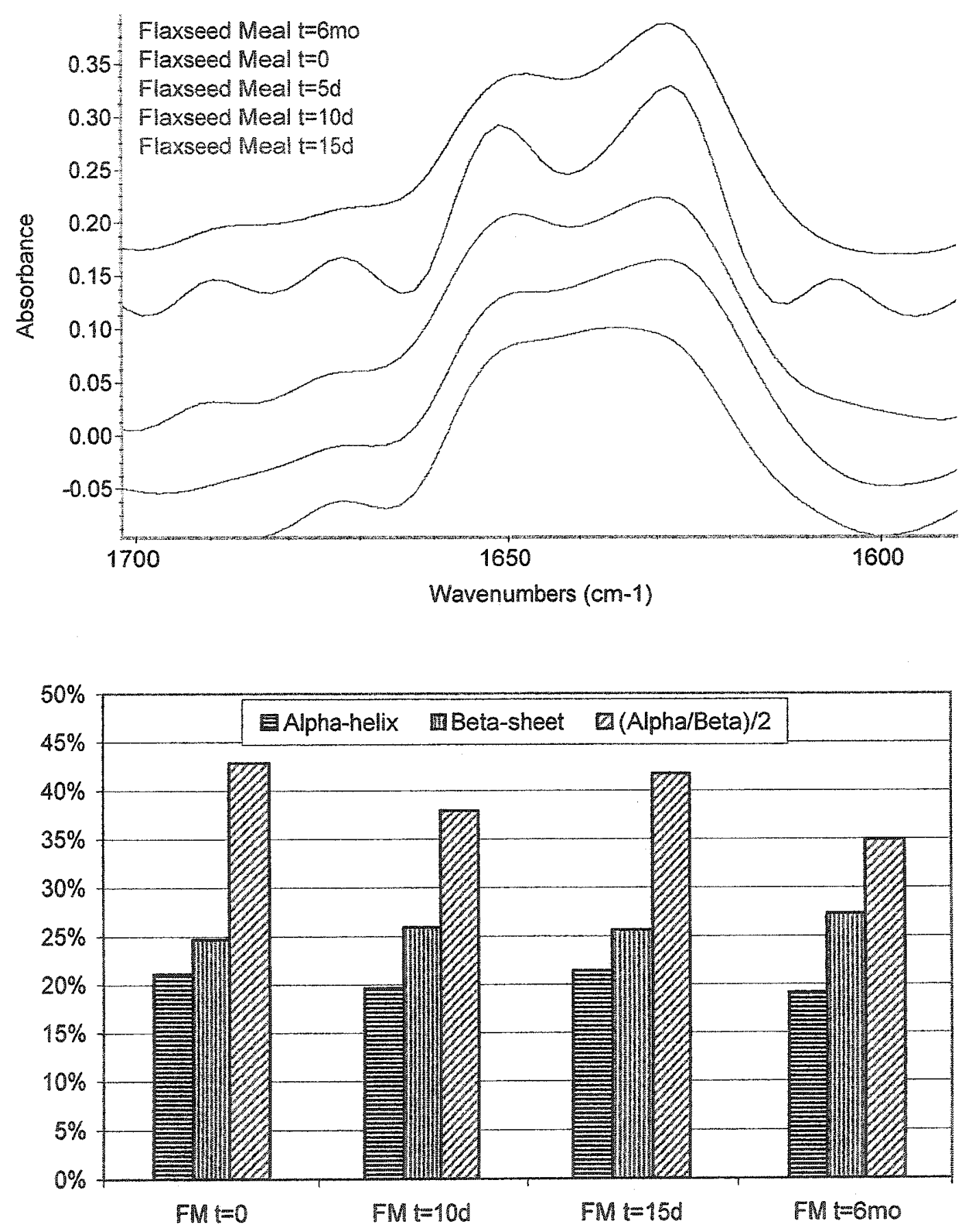

Figure 4.29: Stacked plot of deconvolved FTIR/ATR spectra of surimi with added flaxseed meal during storage at $4^{\circ} \mathrm{C}$ and after 6 mo at $-20^{\circ} \mathrm{C}$ (top); percentage of $\alpha$ helix, $\beta$-sheet structures and their ratio (bottom). The spectra have been offset for clarity. 

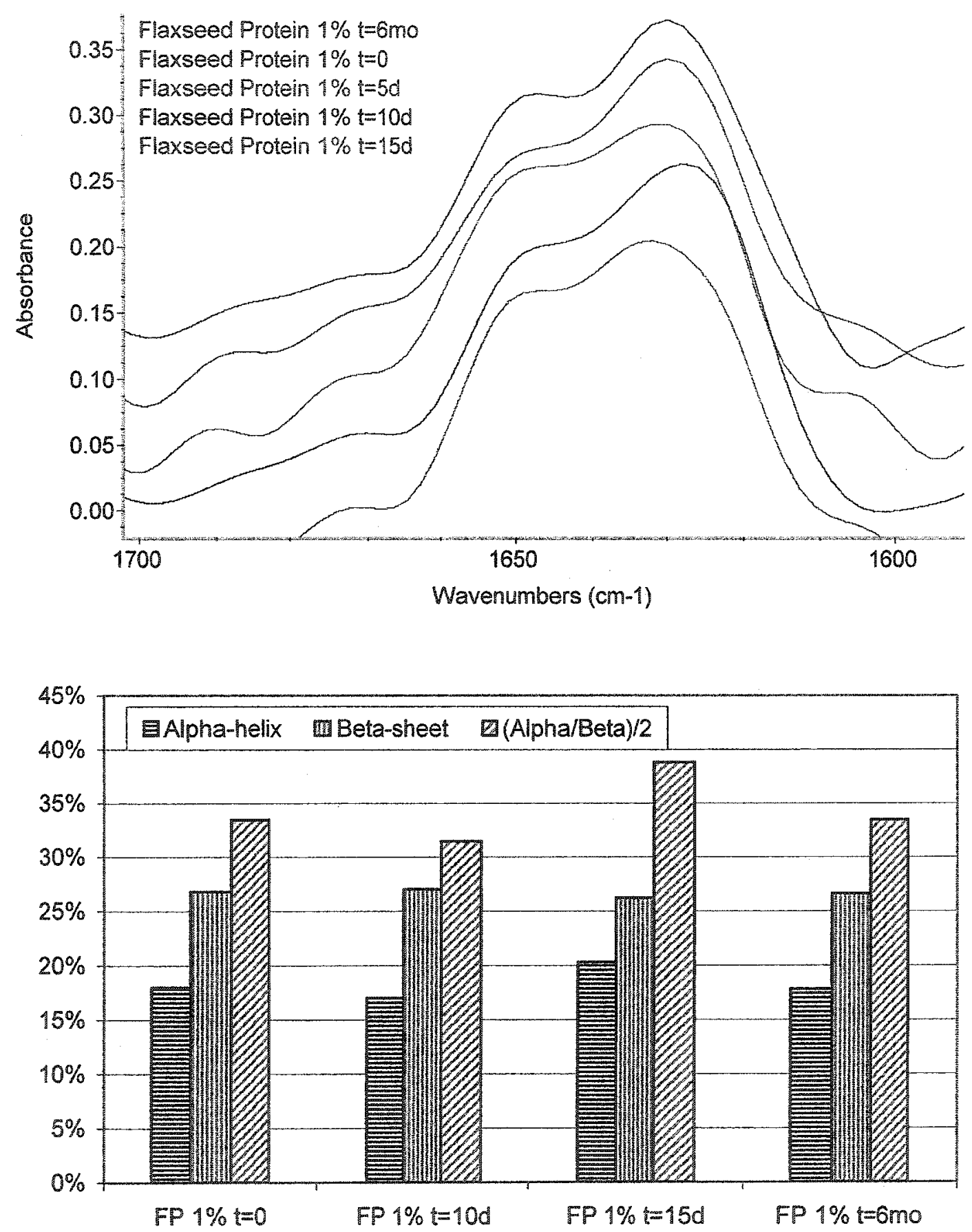

Figure 4.30: Stacked plot of deconvolved FTIR/ATR spectra of surimi with added $1 \%$ flaxseed protein during storage at $4^{\circ} \mathrm{C}$ and after $6 \mathrm{mo}$ at $-20^{\circ} \mathrm{C}$ (top); percentage of $\alpha$-helix, $\beta$-sheet structures and their ratio (bottom). The spectra have been offset for clarity. 
In surimi with added $3 \%$ flaxseed protein (FP 3\%), there was an increase in the ratio of $\alpha$-helix to $\beta$-sheet after 6 mo storage at $-20^{\circ} \mathrm{C}$. During storage at $4^{\circ} \mathrm{C}$, surimi showed a much higher ratio of $\alpha$-helix to $\beta$-sheet after $10 \mathrm{~d}$ compared to $15 \mathrm{~d}$ (Figure 4.31).

Figure 4.32 shows the value of the percent change in the ratio of $\alpha$-helix to $\beta$ sheet structures after 6 mo storage at $-20^{\circ} \mathrm{C}$ compared to time 0 for control (surimi $3^{\text {rd }}$ ) and surimis with different added cryoprotectants. It is postulated here that a change in this ratio is an indication of a change in the protein secondary structure. Therefore, the lower the change in this ratio during storage, the more effective the added component in preserving the protein structures. Based on the percent changes in the ratio of $\alpha$ helix to $\beta$-sheet structures shown in Figure 4.32, it may be concluded that flaxseed protein (FP) was the most effective cryoprotectant (no change for surimi with $1 \% \mathrm{FP}$, and a slight change for surimi with $3 \% \mathrm{FP}$ ) followed by whey protein isolate and soy protein isolate. Whey protein concentrate and flaxseed meal showed the least cryoprotective ability. Since flaxseed protein was effective at both concentrations of $1 \%$ and $3 \%$ in maintaining the secondary structure of fish proteins, it can be suggested to use $1 \%$ flaxseed protein due to possible formation of off-flavors at higher concentrations. Other additives than flaxseed protein may not maintain the secondary structure of proteins but still play a role by modifying the structure such that the product does not become firm or gelled, and hence improve the texture of the product. 

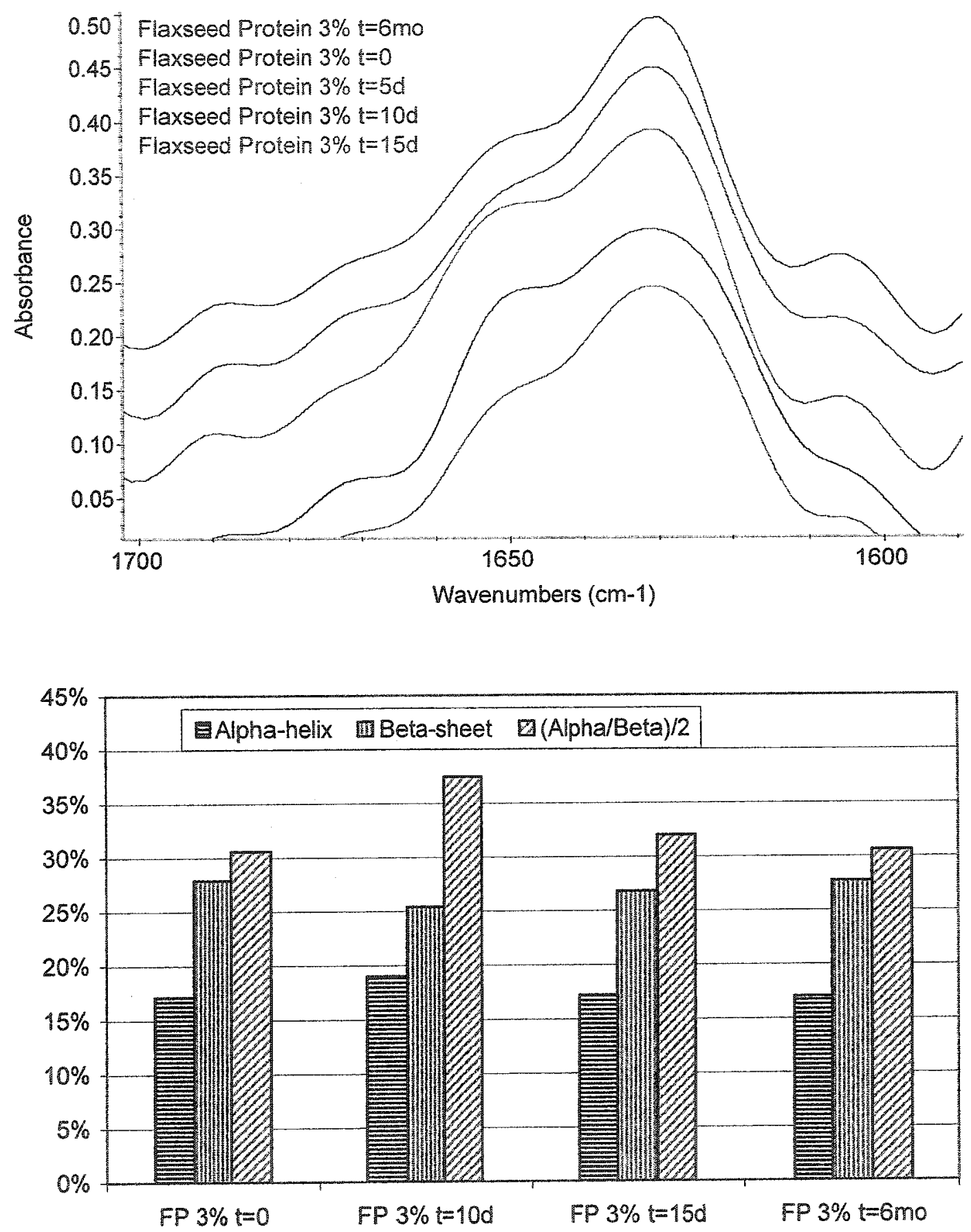

Figure 4.31: Stacked plot of deconvolved FTIR/ATR spectra of surimi with added $3 \%$ flaxseed protein during storage at $4^{\circ} \mathrm{C}$ and after 6 mo at $-20^{\circ} \mathrm{C}$ (top); percentage of $\alpha$-helix, $\beta$-sheet structures and their ratio (bottom). The spectra have been offset for clarity. 


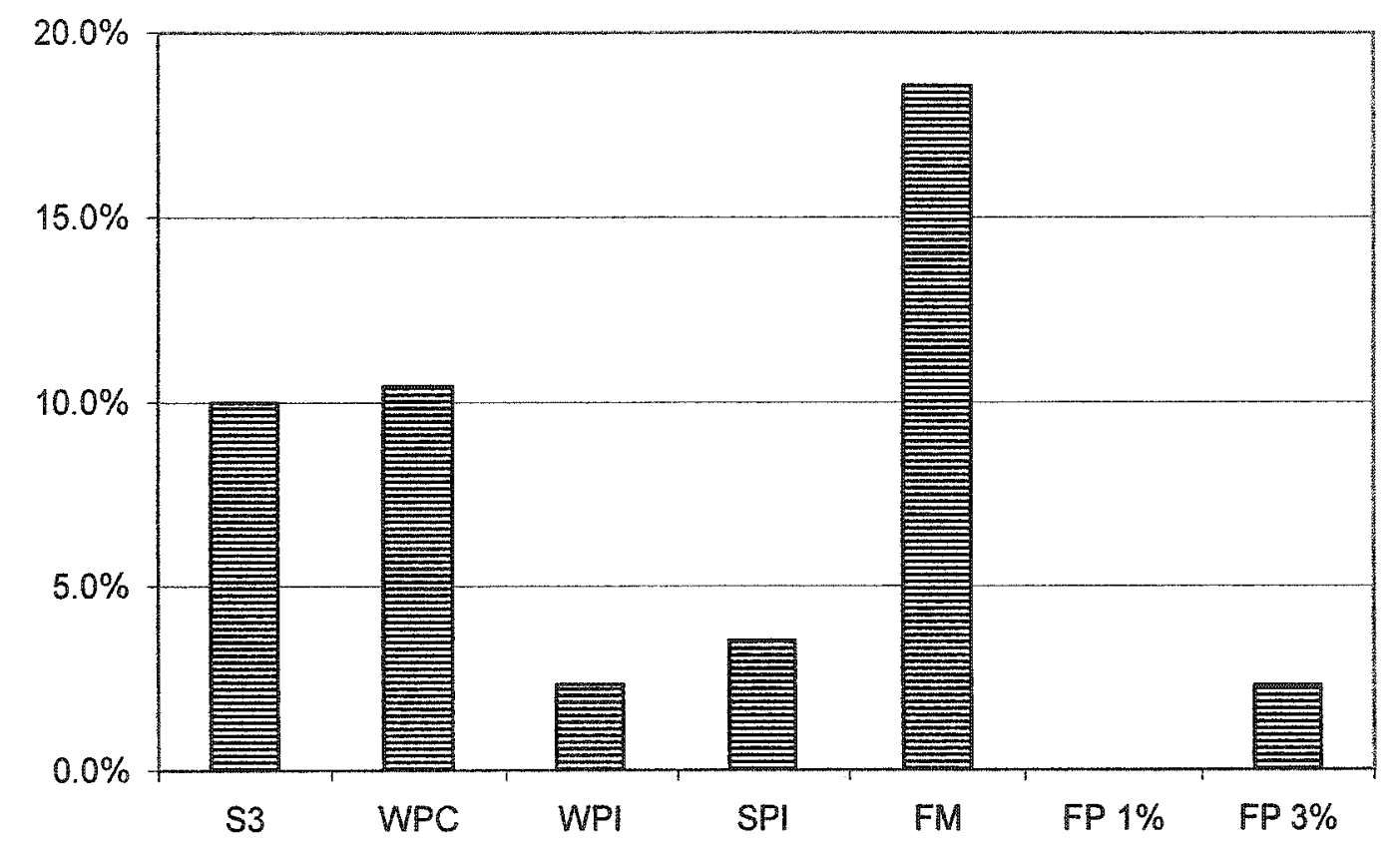

Figure 4.32: Percent change in the ratio of $\alpha$-helix to $\beta$-sheet structures after 6 mo storage at $-20^{\circ} \mathrm{C}$ compared to time 0 , for control (surimi $3^{\text {rd }}$ ) and surimis with different added cryoprotectants: surimi $3^{\text {rd }}(\mathrm{S} 3$ ), whey protein concentrate (WPC), whey protein isolate (WPI), soy protein isolate (SPI), flaxseed meal (FM), flaxseed protein at 1\% (FP 1\%), flaxseed protein at 3\% (FP 3\%). 
Overall, it is observed here that the ratio of $\alpha$-helix to $\beta$-sheet structures may be used as an indicator of such quality characteristics of the product as protein stability, texture, and even microbial spoilage. It is also suggested that the results from $10 \mathrm{~d}$ storage at $4^{\circ} \mathrm{C}$ may be comparable to the results obtained after 6 mo storage at $-20^{\circ} \mathrm{C}$. As another observation, it is stated here that the storage at $4^{\circ} \mathrm{C}$ can be further investigated incorporating antimicrobial agents in the preparation of product samples. 


\section{Chapter 5}

\section{GENERAL CONCLUSIONS}

\subsection{Summary and Conclusion}

Although it is accepted that denaturation of myofibrillar proteins occurs during frozen storage, little direct evidence on the structural changes occurring in muscle proteins during freezing and frozen storage is found other than loss of protein function or functionality. Thus, in this work protein structural changes during preparation and storage of surimi were investigated. Furthermore, the effects of different added cryoprotectants to stabilize the protein structure were studied.

The washing procedure for preparation of surimi has a major effect on the final quality of surimi. The results obtained indicate that factors such as wash/meat ratio, washing steps, and washing time are important for surimi processing to optimize quality and yield of surimi and also to minimize water usage and waste water treatment. Solubilization of myofibrillar proteins at zero to low salt concentration was not generally accepted according to classical muscle chemistry.

FTIR/ATR spectroscopy showed that during preparation of surimi the $\alpha$-helix content increased with increased number of washing cycles. DSC results revealed a shift in the thermal transition of actin to a higher temperature during surimi preparation. All electrophoresis, FTIR/ATR spectroscopy and DSC results revealed a loss of myofibrillar proteins from surimi after three washing cycles, suggesting that three washing cycles were adequate to prepare surimi. 
Electrophoretic analyses in this study revealed that surimi was stable up to $2 \mathrm{yr}$ at $-20^{\circ} \mathrm{C}$, and also rapid freezing using liquid air had no apparent effect on the quality of surimi compared to slow freezing. However, structural changes in protein were detected using FTIR/ATR analyses and were confirmed by DSC analysis. FTIR/ATR spectroscopy revealed that rapid freezing is effective in maintaining the secondary structure of proteins during frozen storage.

The results from the FTIR studies of proteins in surimi suggest that the ratio of $\alpha$-helix to $\beta$-sheet structures may be used as an indicator of such quality characteristics of the product as protein stability, texture, and even microbial spoilage. It is also suggested that the results from $10 \mathrm{~d}$ storage at $4^{\circ} \mathrm{C}$ may be comparable to the results obtained after 6 months storage at $-20^{\circ} \mathrm{C}$. Based on the percent changes in the ratio of $\alpha$-helix to $\beta$-sheet structures, it may be concluded that flaxseed protein had the most cryoprotective effect followed by whey protein isolate and soy protein isolate. Whey protein concentrate and flaxseed meal showed the least cryoprotective ability. After 15 days storage at $4^{\circ} \mathrm{C}$, the SDS-PAGE results showed that flaxseed protein was the only additive that could inhibit the degradation of myosin heavy chain, actin and myosin light chains. As a result, flaxseed protein shows potential as an effective functional cryoprotectant for fish proteins. The results suggest that secondary and other structural changes induced by addition of the cryoprotectants to surimi before freezing may play an important role in stabilization of the fish proteins against the deteriorative changes that are usually observed during frozen storage without addition of cryoprotectants. 


\subsection{Future Work}

A comparison of the results obtained in cold temperature storage (at $4^{\circ} \mathrm{C}$ ) to those from frozen storage $\left(a t-20^{\circ} \mathrm{C}\right)$ suggest that microbial activity may interfere with the biochemical changes in surimi protein when stored at high temperature. Therefore, it can be suggested to further investigate storage at $4^{\circ} \mathrm{C}$ in a future work incorporating antimicrobial agents in the preparation of product samples. Future work may also include identifying new cryoprotectants (both intrinsic and added), and synergistic blends of cryoprotectants to stabilize and to improve the functionality of surimi protein. The search for such new cryoprotectants may be focused on reducing the sweetness and calorie contents of the product. Furthermore, developing new techniques to prepare surimi such as acid-aided processes may have a positive impact on surimi industry. 


\section{References}

Abdolgader R.E. 2000. Isolation and Characterization of a High Gelling Protein from Soybean. Ph.D. Thesis, McGill University, Montreal, Canada.

AbuDagga Y. and Kolbe E. 1997. Thermophysical properties of surimi paste at cooking temperature. J. Food Eng. 32:325-337.

Al-Jowder O., Kemsley E.K. and Wilson R.H. 1997. Mid-infrared spectroscopy and authenticity problems in selected meats-A feasibility study. Food Chem. 59:195-201.

Alli I and Baker B.E. 1983. Constitution of leguminous seeds. Polyacrylamide-disc gel electrophoresis of acid soluble and acid precipitated proteins prepared from baby lima beans. J. Sci. Food Agric. 34:737-742.

An H., Seymour T.A., Wu J.W. and Morrissey M.T. 1994. Assay systems and characterization of Pacific whiting (Merluccius productus) protease. J. Food Sci. 59:277-281.

Anderson L.R. and Wolf W.J. 1995. Compositional changes in trypsin inhibitors, phytic acid, saponins and isoflaones related to soybean processing. J. Nutr. 125:581S-588S.

Arakawa T. and Timasheff S.N. 1982. Stabilization of protein structure by sugars. Biochemistry, 21:6536-6544.

Auh J.H., Lee H.G., Kim J.W. Yoon H.S. and Park K.H. 1999. Highly concentrated branched oligosaccharides as cryoprotectant for surimi. J. Food Sci. 64:418422. 
Back J.F., Oakenfull D. and Smith M.B. 1979. Increased thermal stability of proteins in the presence of sugars and polyols. Biochem. 18:5191-5196.

Barrett T.W. and Peticolas W.L. 1978. Laser Raman light scattering observations of conformational changes in myosin induced by inorganic salts. Biophys. $J$. 23:349-358.

Boye, J.I., 1995. Thermodynamic and Structural Properties Related to the Gelation of Whey Proteins, Ph.D. Thesis, McGill University, Montreal, Canada.

Byler D.M. and Susi H. 1986. Examination of the secondary structure of proteins by deconvolved FTIR spectra. Biopolymers, 25:469-487.

Careche M., Herrero A.M., Rodriguez-Casado A., Del Mazo M.L. and Carmona P. 1999. Structural changes of hake (Merluccius merluccius L.) fillets: effect of freezing and frozen storage. J. Agric. Food Chem. 47:952-959.

Careche M., Li-Chan E.C.Y. 1997. Structural changes in cod myosin upon modification with formaldehyde or frozen storage. J. Food Sci. 62:717-723.

Carew E.B., Asher I.M. and Stanley H.E. 1975. Laser Raman spectroscopy-new probe of myosin substructure. Science, 188:933-936.

Carvajal P.A., MacDonald G.A, and Lanier T.C. 1999. Cryostabilization mechanism of fish muscle proteins by maltodextrins. Cryobiology, 38:16-26.

Chen Y.H., Yang J.T. and Chau K.H. 1974. Determination of the helix and $\beta$ form of proteins in aqueous solution by circular dichroism. Biochemistry, 13:33503359. 
Choi Y.J. and Park J.W. 2002. Acid-aided protein recovery from enzyme-rich Pacific whiting. J. Food Sci. 67:2962-2967.

Compton L.A., Johnson W.C. Jr. 1986. Analysis of protein circular dichroism spectra for secondary structure using a simple matrix multiplication. Anal. Biochem. 155:155-167.

Connell J.J. 1960. Changes in the actin of cod flesh during storage at $-14^{\circ} \mathrm{C}$. J. Sci. Food Agric. 11:515-519.

Connell J,J.1964. Fish muscle proteins and some effects on them of processing. In: Proteins and their Reactions, H.W. Schultz and A.F. Anglemier (Eds.), Avi, Westport, CT, 255-293.

Cowie W.P. 1968. Identification of fish species by thin slab polyacrylamide gel electrophoresis of the muscle myogens. J. Sci. Food Agric. 19:226-229.

Darwish G.S., van de Voort F.R. and Smith J.P. 1989. Proximate analysis of fish tissue by mid-infrared transmission spectroscopy. Can. J. Fish Aquat. Sci. 46:644649.

Davis B.J. 1964. Disc electrophoresis-Method and application to human serum proteins, Ann. N.Y.Acad. Sci. 121:404-427.

Davidson R.M., Sand R.E. and Johnson R.E. 1979. Methods for Processing Soy Protein and Composition of Matter. U.S. patent no. 4,172, 828.

Dev D.K. and Quensel E. 1986. Functional and microstructural characteristics of linseed (Linum ussitatissimum L.) flour and a protein isolate. Lebensm.-Wiss. 4.-Technol. 19:331-337. 
Dev D.K. and Quensel E. 1988. Preparation and functional properties of linseed protein products containing differing levels of mucilage. J. Food Sci. 53:1834-1837, 1857.

Dev D.K. and Quensel E. 1989. Functional properties of linseed protein products containing different levels of mucilage in selected food systems. J. Food Sci. 54:183-186.

Dev D.K., Sienkiewicz T., Quensel E. and Hansen R. 1986. Isolation and partial characterization of flaxseed (Linum usitatissimum L.) proteins. Die Nahrung, 30:391-393.

Dyer J.W., French H.V. and Snow J.M. 1950. Proteins in fish muscle I. Extraction of protein fractions on fresh fish. J. Fish Bd. Can. 7:585-593.

Ferry J.D. 1948. Protein gels. Adv. Protein Chem. 4:1-78.

Gangidi R.R., Proctor A. and Pohlman F.W. 2003. Rapid determination of spinal cord content in ground beef by attenuated total reflectance Fourier transform infrared spectroscopy. J. Food Sci, 68:124-127.

Giese J. 1994. Proteins as ingredients: Types, function, applications. Food Technol. $48: 50-60$.

Goodband R. 2002. Functional properties of fish proteins. In: Seafoods-Quality, Technology, and Nutraceutical Applications, C. Alasalvar and T. Taylor (Eds.), Springer, Berlin, Germany, pp 73-82.

Haard N.F. 1995. Composition and nutritive value of fish proteins and other nitrogen compounds. In: Fish and Fishery Products: Composition, Nutritive Properties and Stability, A. Ruiter (Ed.), CAB International, UK, pp 120-365. 
Hall G.M. and Ahmad, N.H. 1997. Surimi and fish-mince products, In: Fish Processing Technology. $2^{\text {nd }}$ ed. G.M. Hall (Ed.), Chapman and Hall, London, p 75.

Hamm R. 1960. Biochemistry of meat hydration, in Advances In: Food Research, Vol. 10, C.O.Chichester, E.M. Mrak and G.F. Stewart (Eds.), Academic Press, New York, USA, p 355.

Hamm R. 1986. Functional properties of the myofibrillar system and their measurements, In: Muscle as Food, P.J. Bechtel (Ed.), Academic Press, Orlando, FL, p 135.

Hartree E.F. 1972. Determination of protein: A modification of the Lowry method that gives a linear photometric response. Anal. Biochem. 48:422-427.

Herrera J.J., Pastoriza L. and Sampedro G. 2001. A DSC study on the effects of various maltodextrins and sucrose on protein changes in frozen-stored minced blue whiting muscle. J. Sci. Food Agric, 81:377-384.

Howell B., Matthews A. and Donnelly A. 1991. Thermal stability of fish myofibrils: a different scanning calorimetric study. Int. J. Food Sci. Technol. 26:283-295.

Hsu C.K. and Kolbe E. 1996. The market potential of whey protein concentrate as a functional ingredient in surimi seafoods. J. Dairy Sci. 79:2146-2151.

Hsu C.K., Kolbe E., Morrissey M., Wang D. and MacDonald G. 1993. Comparison of physical, thermal and chemical methods to measure protein denaturation in frozen Pacific whiting (Merluccius productus). J. Aquatic Food Prod. Technol. 2:31-49. 
Hwang I.H., Lin C.W. and Chou R.G.R. 2000, Effect of lactic or acetic acid on degradation of myofibrillar proteins in postmortem goose (Anser anser) breast muscle. J. Sci. Food Agric. 80:231-236.

Itoh Y., Yoshinaka R. and Ikeda S. 1979. Effects of inorganic reducing agents on the gel formation of fish meat by heating. Bull. Jpn. Soc. Sci. Fish. 45:455-458.

Ismail A.A., Mantsch H.H. and Wong P.T.T. 1992. Aggregation of chymotrypsinogen: portrait by infrared spectroscopy. Biochim. Biophys. Acta. 1121:183-188.

Jackson M. and Mantsch H.H. 1995. The use and misuse of FTIR spectroscopy in the determination of protein structure. Crit. Rev. Biochem, Mol. Biol. 30:95-120.

Jasra S.K., Jasra P.K. and Talesara C.L. 2001. Myofibrillar protein degradation of carp (Labeo rohita (Hamilton)) muscle after post-mortem unfrozen and frozen storage. J. Sci. Food Agric. 81:519-524.

Kim Y.S., Park J.W. and Choi Y.J. 2002. Physiochemical characteristics of fish proteins treated at various $\mathrm{pH}$ conditions. In: IFT Annual Meeting Book of Abstracts. Anaheim, California, USA, pp 124-125.

King F.J. 1966. Ultracentrifugal analysis of changes in the composition of myofibrillar protein extracts obtained from fresh and frozen cod muscle. J. Food Sci. $31: 649-663$.

Kinsella J.E. 1976. Functional properties of proteins in foods: a survey. Crit. Rev. Food Sci. Nutr. 7:219-280.

Koohmaraie M., Kennick W.H., Elgasim E.A. and Anglemier A.F. 1984. Effects of postmortem storage on muscle protein degradation: analysis by SDSpolyacrylamide gel electrophoresis. J. Food Sci. 49:292-294. 
Kristinsson H.G. and Rasco B.A. 2000. Fish protein hydrolysates: production, biochemical, and functional properties. Crit. Rev. Food Sci. Nutr. 40:43-81.

Laemmli U.K. 1970. Cleavage of structural proteins during the assembly of the head of bacteriophage T4. Nature, 227:680-685.

Lan C.C., Pan B.S. and Jiang S.T. 1987. Effect of reducing agents on protein denaturation of frozen minced lizard fish and textural properties of the cooked product. J. Chin. Agric. Chem. Soc. 25:159-168.

Lanier T.C. 1986. Functional properties of surimi. Food Technol. 40:107-114.

Lanier T.C. 1992. Measurement of surimi composition and functional properties. In: Surimi Technology, T.C. Lanier and C.M. Lee (Eds.), Marcel Dekker, New York, USA, pp 123-163.

Lee C. M. 1986. Surimi manufacturing and fabrication of surimi-based products. Food Technol. 40:115-124.

Lee C.M. 1984. Surimi process technology. Food Technol. 38:69-80.

Li-Chan E., Nakai S. and Hirotsuka M. 1994. Raman spectroscopy as a probe of protein structure in food systems. In: Protein Structure-Function Relationships in Foods, R.Y. Yada, R.L. Jackman and J.L. Smith (Eds.), London, U.K. Blackie Academic and Professional, Chapman and Hall, pp 163-197.

Lin T.M. and Park J.W. 1995. Study of myofibrillar solubility during surimi processing: Effects of washing cycles and ionic strength. Presented at the PFT annual meeting, Mazatlan, Mexico. 
Lowry O.H., Rosebrough N.J., Farr A.L. and Randall R.J. 1951. Protein measurement with Folin phenol reagent. J. Biol. Chem. 193:256-275.

Lyver A., Smith J.P., Austin J, and Blanchfield B. 1998a. Competitive inhibition of Clostridium botulinum type $\mathrm{E}$ by Bacillus species in a value-added seafood product packaged under a modified atmosphere. Food Res. Int. 31:311-319.

Lyver A., Smith J.P., Nattress F.M., Austin J. and Blanchfield B. 1998b. Challenge studies with botulinum type $\mathrm{E}$ in a value-added surimi product stored under a modified atmosphere. J. Food Saf. 18:1-23.

Ma C.-Y., Harwalkar V.R. and Maurice T.J. 1990. Instrumentation and techniques of thermal analysis in food research. In: Thermal Analysis of Foods, V.R. Harwalkar and C.-Y. Ma (Eds.), Elsevier Applied Science, London, pp 1-15.

MacDonald G.A. and Lanier T.C. 1991. Carbohydrates as cryoprotectants for meats and surimi. Food Technol. 45:150-159.

MacDonald G.A., Lanier T.C. and Carvajal P.A. 2000. Stabilization of proteins in surimi. In: Surimi and Surimi Seafood, J.W. Park (Ed.), Marcel Dekker, New York, USA, pp 91-125.

Machado M.G.S. and Sgarbieri V.C. 1991. Partial characterization and nutritional value of proteins from pacu (Colossoma mitrei, Berg 1895). J. Agric. Food Chem. 39:1715-1718.

Mackie I.M. 1993. The effects of freezing on flesh proteins. Food Rev. Int. 9:575-610.

Madhusudhan K.T. and Singh N. 1985a. Isolation and characterization of the major fraction (12S) of linseed proteins. J. Agric. Food Chem. 33:673-677. 
Madhusudhan K.T. and Singh N. 1985b. Isolation and characterization of a small molecular weight protein of linseed meal. Phytochemistry, 24:2507-2509.

Mangino M.E. 1992. Properties of whey protein concentrates. In: Whey and Lactose Processing, J.G. Zadow (Ed.), Elsevier Applied Science, New York, USA, pp 231-270.

Mantulin W.W. and Pownhall H.J. 1986. Fluorescence quenching studies of apolipoprotein A-I in solution and in lipid-protein complexes: protein dynamics. Biochem. 25:8034-8042.

Mao W.W. and Sterling C. 1970. Parameters of texture changes in processed fish: cross-linkage of proteins. J. Texture Stud. 1:484-490.

Matsumoto J.J. 1978. Minced fish technology and its potential for developing countries. In: Processing on Fish Utilization Technology and Marketing, vol. 18, Sec. III., Indo-Pacific Fishery Commision, Bangkok, Thailand, p 267.

Matsumoto J.J. 1980. Chemical deterioration of muscle proteins during frozen storage. In: Whitaker J.R. and Fujimaki M. (Eds.) Chemical Deterioration of Proteins, ACS Symposium Series, 123, American Chemical Society, Washington, DC, pp 95-124.

Matsumoto J. J. and Noguchi, S. 1971. Control of the freezing-denaturation of fish muscle proteins by chemical substances, in Proc. Int. Congr. Refrigeration, Vol. 3, Washington, D.C., p 237.

Matsumoto J.J. and Noguchi S.F. 1992. Cryostabilization of protein in surimi. In: Surimi Technology, T.C. Lanier and C.M. Lee (Eds.), Marcel Dekker, New York, USA, pp 357-388. 
Morr C.V. 1989. Whey proteins: Manufacture. In: Developments in Dairy Chemistry4. Functional Milk Proteins, P.F. Fox (Ed.), Elsevier Applied Science, New York, USA, pp 245-284.

Morr C.V. 1992. Improving the texture and functionality of whey protein concentrate. Food Technol. 46:110-113.

Morrissey M.T. and Tan S.M. 2000. World resources for surimi. In: Surimi and Surimi Seafood, J.W. Park (Ed.), Marcel Dekker, New York, USA, pp 1-21.

Morrissey M.T., Wu J.W., Lin D. and An H. 1993. Protease inhibitor effects on torsion measurements and autolysis of Pacific whiting surimi. J. Food Sci. 58:10501054.

Motohiro T. and Numakura, T. 1978. Utilization of soy proteins in fish gel products. 1. Optimum concentration of protein isolate in broiled-type products. Bull. Fac. Fish. Hokkaido Univ. 29:141-147.

Mulvihill D.M. and Kinsella J.E. 1987. Gelation characteristics of whey proteins and B-lactoglobulin. Food Technol. 41:102-111.

Nakamura T., Utsumi S. and Mori T. 1984. Network structure in thermally induced gelation of glycinin. J. Agric. Food Chem. 32:349-352.

Nishiya $K_{\text {, }}$ Takeda F., Tamoto $K_{\text {., Tanaka }}$. and Kubo T. 1960. Studies on freezing of surimi (fish paste) and its application. III. Influence of salts on quality of fish meat. Monthly Report of Hokkaido Fisheries Research Laboratory, Fisheries Agency, Japan, 17:373-383.

Niwa E. 1975. Role of hydrophobic bonding in gelation of fish flesh paste. Bull. Jpn. Soc. Sci. Fish. 41:907-910. 
Noguchi S. and Matsumoto J.J. 1970. Studies on the control of the denaturation of the fish muscle proteins during the frozen storage. I. Preventive effect of Naglutamate, Bull. Jpn. Soc. Sci. Fish. 36:1078-1087.

Noguchi S. and Matsumoto J.J. 1975. Studies on the control of denaturation of fish muscle proteins during frozen storage. IV. Preventive effect of carboxylic acids. Bull. Jpn. Soc. Sci. Fish. 41:329-335.

Noguchi S., Oosawa K. and Matsumoto J.J. 1976. Studies on the control of denaturation of fish muscle proteins during frozen storage. VI. Preventive effect of carbohydrates. Bull. Jpn. Soc. Sci. Fish. 42:77-82.

Noguchi S., Shinoda E. and Matsumoto J.J. 1975. Studies on the control of denaturation of fish muscle proteins during frozen storage. V. Technological application of cryoprotective substances on the frozen minced fish meat. Bull. Jpn. Soc. Sci. Fish. 41:779-786.

Numakura T., Seki N., Kimura I., Toyoda K., Fujita T., Takama K. and Arai, K.I. 1987. Effect of quality of Surimi on cross-linking reaction of myosin heavy chain during setting. Nippon Suisan Gakkaishi. 53:633-639.

Ogawa M., Kanamaru J., Miyashita H., Tamiya T. and Tsuchiya T. 1995. Alpha-helical structure of fish actomyosin: Changes during setting. J. Food Sci. 60:297-299.

Ogawa M., Tamiya T. and Tsuchiya T. 1996. $\alpha$-helical structure of fish actomyosin changes during storage. J. Agric. Food Chem. 44:2944-2945.

Ogawa M., Nakamura S., Horimoto Y, An H., Tsuchiya T. and Nakai S. 1999. Raman spectroscopic study of changes in fish actomyosin during setting. J. Agric. Food Chem. 47:3309-3318. 
Ohnishi M., Tsuchiya T. and Matsumoto J.J. 1978. Electron microscopic study of the cryoprotective effect of amino acids on freeze denaturation of carp actomyosin. Bull. Jpn. Soc. Sci. Fish. 44:755-762.

Oomah B.D. and Mazza G. 1993. Flaxseed proteins-a review. Food Chem. 48:109114.

Pan B.S. 1986. Texture and chemical properties of minced fish products as affected by physical treatments. In: Role of Chemistry in the Quality of Processed Food, O.R.Fennema, W.H. Chang and C.Y. Lii (Eds.), Food and Nutrition Press, Westport, CT, p 225.

Pan B.S. 1990. Minced fish technology. In: Seafood: Resources, Nutritional Composition, and Preservation, Z.E. Sikorski (Ed.), CRC Press, Boca Raton, Florida, USA, pp 199-210.

Pan B.S., Lee D.J. and Lin L.P. 1979. Studies on a minced squid product: effect of raw material and ingredients on the texture of the product. In Advances in Fish Science and Technology, J.J. Connell (Ed.), Fishing News Books, Farnham, England, p 232.

Pan B.S., Shiau C.Y. and Chen S. 1981. Effect of extender on minced fish product, in Recent Advances in Food Science and Technology, C.C. Tsen and C.C. Lii, (Eds.), Hua Shiang Yuan Publishing, Taipei, Republic of China, $\mathrm{p} 85$.

Park J.W. 1994. Cryoprotection of muscle proteins by carbohydrates and polyalcoholsa review. J. Aquatic Food Prod. Technol. 3:23-41. 
Park J.W. 2001. New developments in surimi and surimi seafood. In: $11^{\text {th }}$ World Congress of Food Science and Technology Book of Abstracts, Seoul, Korea, p 55 .

Park J.W. and Lanier T. 1987. Combined effects of phosphates and sugar or polyol on protein stabilization of fish myofibrils. J. Food Sci. 52:1509-1513.

Park J.W. and Lanier T.C. 1989. Scanning calorimetric behavior of Tilapia myosin and actin due to processing of muscle and protein purification. $J$. Food Sci. 54:49 51 .

Park J.W., Lanier T.C., Keeton J.T. and Hamann D.D. 1987. Use of cryoprotectants to stabilize functional properties of pre-rigor salted beef during frozen storage. $J$. Food Sci. 52:537-542.

Park J.W., Lin T.M. and Yongsawatdigul J. 1997. New developments in manufacturing of surimi and surimi seafood. Food Rev. Int. 13:577-610.

Park J.W. and Morrissey M.T. 2000. Manufacturing of surimi from light muscle fish. In: Surimi and Surimi Seafood, J.W. Park (Ed.), Marcel Dekker, New York, USA, pp 23-58.

Poulter R., Ledward D., Godber S., Hall G. and Rowlands B. 1985. Heat stability of fish muscle proteins. J. Food Tech. 20:203-217.

Rackis J.J., McGhee J.E and Honig D.H. 1975. Processing soybeans into foods: selected aspects of nutrition and flavor. J. Am. Oil Chem. Soc. 52:249A-253A.

Ragnarsson K and Regenstein J.M. 1989. Changes in electrophoretic patterns of gadoid and non-gadoid fish muscle during frozen storage. J. Food Sci. 54:819-823. 
Ramirez J.A., Martin-Polo M.O. and Bandman E. 2000. Fish myosin aggregation as affected by freezing and initial physical state. J. Food Sci. 65:556-560.

Rattrie N.W. and Regenstein J.M. 1977. Action of crude papain on actin and myosin heavy chains isolated from chicken breast muscle. J. Food Sci, 42:1159-1163.

Regenstein, J.M. and Regenstein C.E. 1984. Food Protein Chemistry. Academic Press, London, pp 274-334.

Roessink G.L. 1989. Battered and breaded products. Infofish Int. 4:17-20.

Sammour R.H. 1994. The seed proteins of linseed (Linum usitatissimum L.). Bot. Bull. Acad. Sin. 35:171-177.

Sano T,, Noguchi S.F., Tsuchiya T. and Matsumoto J.J. 1988. Dynamic viscoelastic behavior of natural actomyosin and myosin during thermal gelation. J. Food Sci. 53:924-928.

Sato S., Nakagawa N., Tsuchiya T. and Matsumoto J.J. 1987. Electron microscopic study on the processes of preparation of kamaboko. Bull. Jpn. Soc. Sci. Fish. $53: 649-658$.

Scott D.N., Porter R.W., Kudo G., Miller R. and Koury B. 1988. Effect of freezing and frozen storage of Alaska pollock on the chemical and gel-forming properties of surimi. J. Food Sci. 58:353-358.

Sedman J., van de Voort F. and Ismail A.A. 1999. Attenuated total reflectance spectroscopy: principles and applications in infrared analysis of food. In: Spectral Methods In Food Analysis, M.M, Mossoba (Ed.), Marcel Dekker, New York. USA, pp 397-425. 
Shahidi F. 1997. Seafood safety, processing and biotechnology: an overview. In: Seafood Safety, Processing, and Biotechnology, F. Shahidi, Y. Jones and D.D. Kitts (Eds.), Technomic Publishing, Lancaster, USA, pp 1-3.

Sikorski Z., Olley J. and Kostuch S. 1976. Protein changes in frozen fish. Crit. Rev. Food Sci. Nutr. 8:97-129.

Sikorski Z.E. and Naczk M. 1981. Modification of technological properties of fish protein concentrates. Crit. Rev. Food Sci. Nutr. 14:201-230.

Sikorski Z.E., Kolakowska A. and Burt J.R. 1990a. Postharvest biochemical and microbial changes. In: Seafood: Resources, Nutritional Composition, and Preservation, Z.E. Sikorski (Ed.), CRC Press, Boca Raton, Florida, USA, pp $55-75$.

Sikorski Z.E., Kolakowska A. and Pan B.S. 1990b. The nutritive composition of the major groups of marine food organisms. In: Seafood: Resources, Nutritional Composition, and Preservation, Z.E. Sikorski (Ed.), CRC Press, Boca Raton, Florida, USA, pp $29-54$.

Smith A.K., Johnsen V.L. and Beckel A.C. 1946. Alkali dispersion and acid precipitation. Ind. Eng. Chem. 38:353-356.

Sonu S.C. 1986. Surimi. NOAA Technical Memorandum, NMFS.

Stefansson $\mathrm{G}$. and Hultin H.O. 1994. On the solubility of cod muscle proteins in water. J. Agric. Food Chem. 42:2656-2664.

Stroud R.G. 1969. Rigor in Fish. The Effect on Quality, Torry Advisory Note No. 36, Edinburgh. 
Stuart B. 1997. Biological Applications of Infrared Spectroscopy. John Wiley and Sons, Chichester, England, p 191.

Sultanbawa Y., Li-Chan E.C.Y. 1998. Cryoprotective effects of sugar and polyol blends in ling cod surimi during frozen storage. Food Res. Int. 31:87-98.

Sultanbawa Y., Li-Chan E.C.Y. 2001. Structural changes in natural actomyosin and surimi from ling cod (Ophiodon elongatus) during frozen storage in the absence or presence of cryoprotectants. J. Agric. Food Chem. 49:4716-4725.

Surewicz W.K. and Mantsch H.H. 1988. New insight into protein secondary structure from resolution-enhanced infrared spectra. Biochim. Biophys. Acta. 952:115130.

Surewicz W.K., Mantsch H.H. and Chapman D. 1993. Determination of protein secondary structure by Fourier transform infrared spectroscopy: A critical assessment. Biochemistry, 32:389-394.

Sych J., Lacroix C., Adambounou L. and Castaigne F. 1990. Cryoprotective effect of lactitol, palatinit and polydextrose on cod surimi proteins during frozen storage. J. Food Sci. 55:356-360.

Togashi M., Kakinuma M. and Nakaya M. 2002. Differential scanning calorimetry and circular dichroism spectrometry of Walleye pollack myosin and light meromyosin. J. Agric. Food Chem. 50:4803-4811.

Toyohara H., Sakata T., Yamshita K., Kinoshita M. and Shimizu Y. 1990. Degradation of oval filefish meat gel caused by myofibrillar proteinase(s). J. Food Sci. 55: 364-368. 
Tsuchiya T., Tsuchiya Y., Nonomura Y. and Matsumoto J.J. 1975. Prevention of freeze denaturation of crab actomyosin by sodium glutamate. J. Biochem. 77:853-862.

Venugopal V. and Shahidi F. 1994. Thermostable water dispersions of myofibrillar proteins from Atlantic mackerel (Somber scombrus). J. Food Sci. 59:265-268.

Venugopal V. and Shahidi F. 1995. Value-added products from underutilized fish species. Crit. Rev. Food Sci. Nutr. 35:431-453.

Visessanguan W., Ogawa M., Nakai S. and An H. 2000. Physiochemical changes and mechanism of heat-induced gelation of arrowtooth flounder myosin. J. Agric. Food Chem. 48:1016-1023.

Wang Z., Wang Z., Tao S., Hu C., Xing Q. and Zhu Y. 2001. Effect of rinsing operation on freezing denaturation of surimi protein. JIRCAS Working Report No. 20. pp 73-78.

Weber K. and Osborn M. 1969. The reliability of molecular weight determination by dodecyl sulfate polyacrylamide gel electrophoresis. J. Biol. Chem. 244:44064412.

Weerasinghe V.C., Morrissey M.T., Chung Y.-C. and An H. 1996. Whey protein concentrate as a proteinase inhibitor in Pacific whiting surimi. J. Food Sci. $61: 367-371$.

Wilder C.L., Friedrich A.D., Potts R.O., Daumy G.O. and Francoeur M.L. 1992. Secondary structure analysis of two recombinant murine proteins, interleukins $1 \alpha$ and $1 \beta$ : is infrared spectroscopy sufficient to assign structure? Biochemistry. $31: 27-31$. 
Wright D., Leach I and Wilding P. 1977. Differential scanning calorimetric studies of muscle and its constituent proteins. J. Sci. Food Agr. 28:557-564.

Wu M.C., Lanier T.C. and Hamann D.D. 1985. Thermal transitions of admixed starch/fish protein systems during heating. J. Food Sci. 50:20-25.

Xiong Y.L. 1997. Structure-Function Relationships of Muscle Proteins. In: Food Proteins and Their Applications, S. Damodaran and A. Paraf (Eds.), Marcel Dekker, New York, USA, pp 341-392.

Yoon K.S. and Lee C.M. 1990. Cryoprotectant effects in surimi and surimi/mincebased extruded products. J. Food Sci. 55:1210-1216.

Zalke J. 1992. Global markets for surimi-based products. In: Pacific Whiting: Harvesting, Processing, Marketing, and Quality Assurance, G. Sylvia and M.T. Morrissey (Eds.), p 6. 